Grayce Kelly Bianconi João Dallamuta (Organizadores)

\title{
Inovação, Gestão Estratégica e Controladoria nas Organizações 3
}

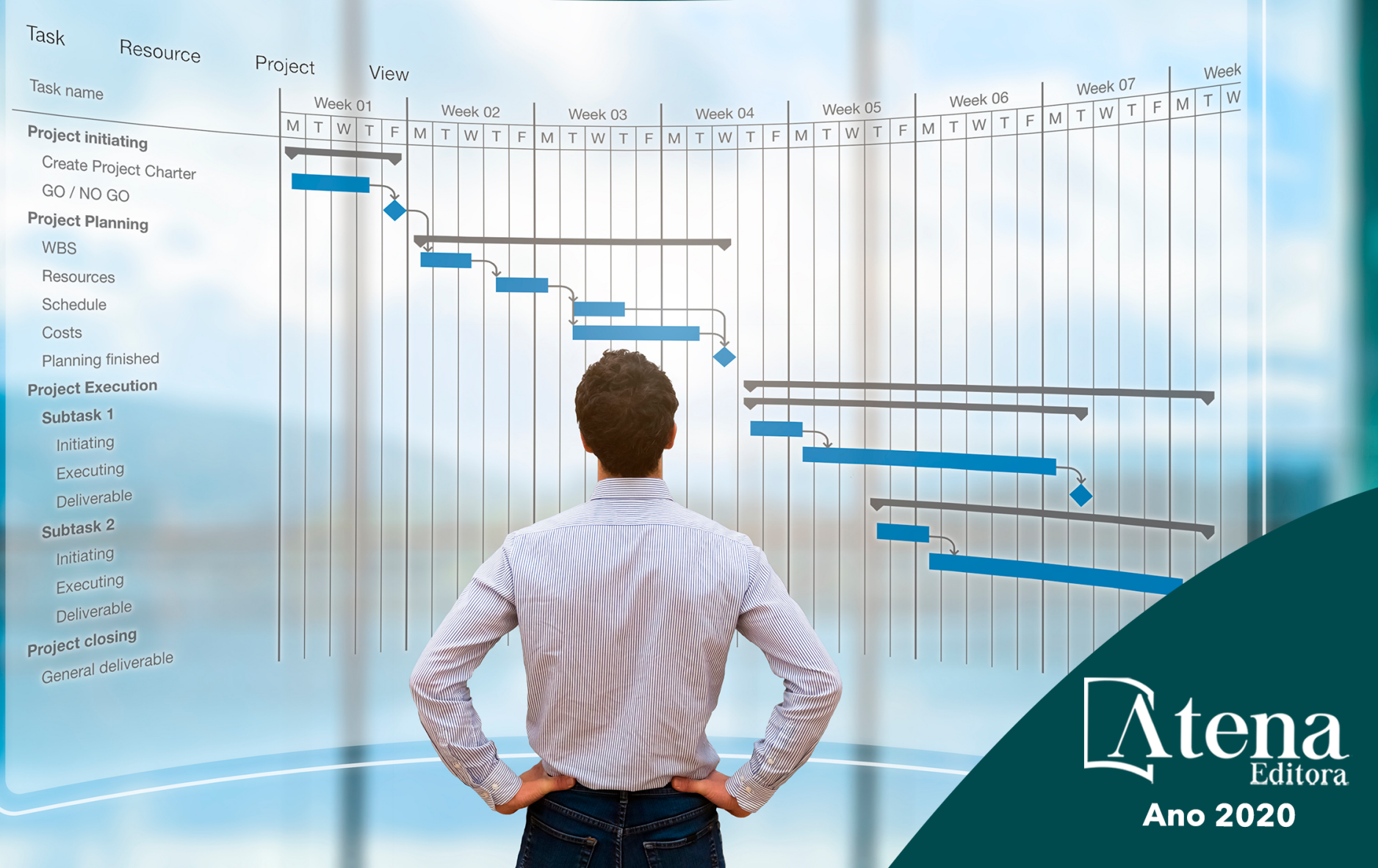


Grayce Kelly Bianconi João Dallamuta (Organizadores)

\section{Inovação, Gestão Estratégica e Controladoria nas Organizações 3}

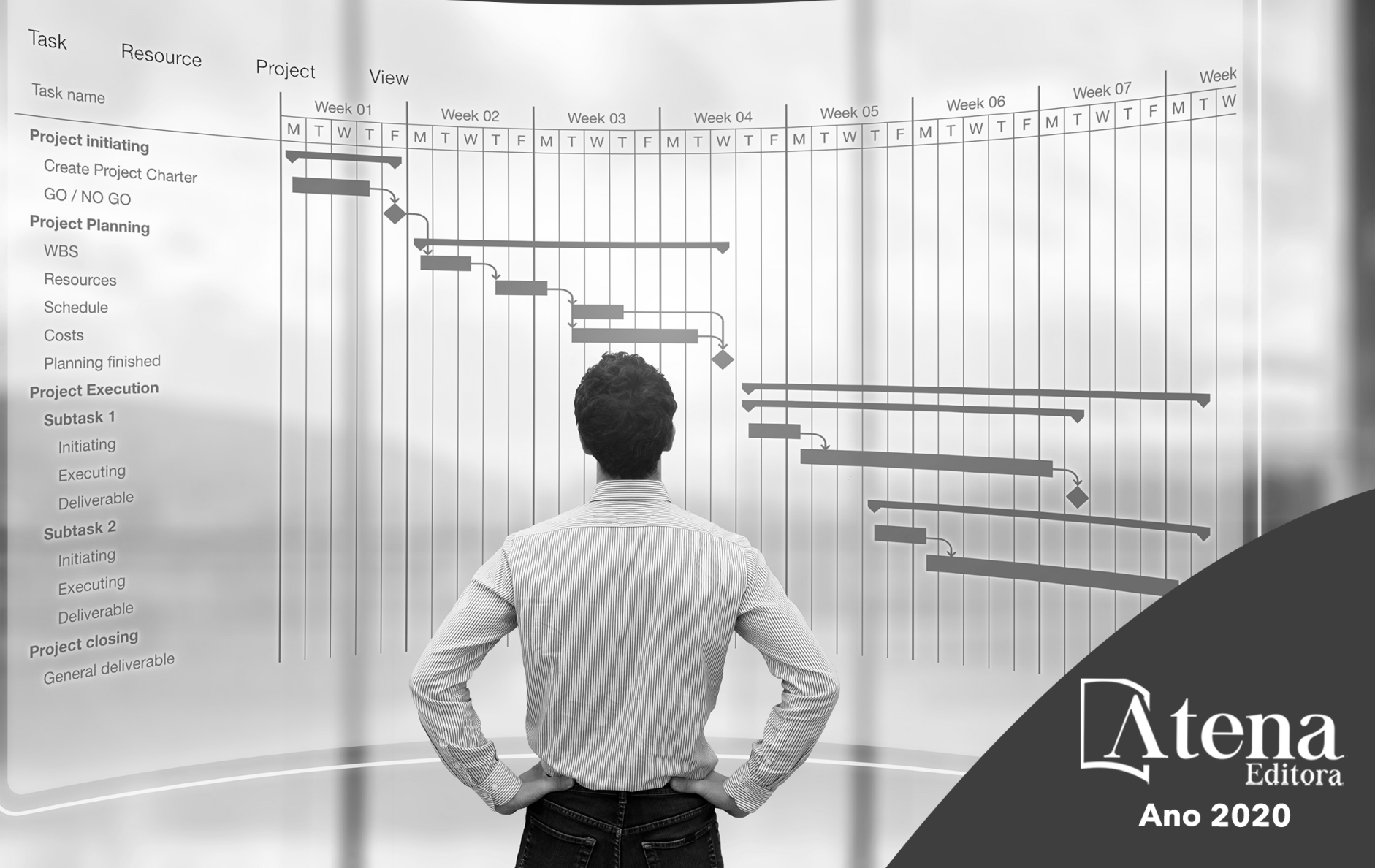




\author{
2020 by Atena Editora \\ Copyright (C) Atena Editora \\ Copyright do Texto (C) 2020 Os autores \\ Copyright da Edição (c) 2020 Atena Editora \\ Editora Chefe: Prof ${ }^{\mathrm{a}}$ Dr $^{\mathrm{a}}$ Antonella Carvalho de Oliveira \\ Diagramação: Lorena Prestes \\ Edição de Arte: Lorena Prestes \\ Revisão: Os Autores
}

Todo o conteúdo deste livro está licenciado sob uma Licença de Atribuição Creative

Commons. Atribuição 4.0 Internacional (CC BY 4.0).

O conteúdo dos artigos e seus dados em sua forma, correção e confiabilidade são de responsabilidade exclusiva dos autores. Permitido o download da obra e o compartilhamento desde que sejam atribuídos créditos aos autores, mas sem a possibilidade de alterá-la de nenhuma forma ou utilizá-la para fins comerciais.

\title{
Conselho Editorial
}

\section{Ciências Humanas e Sociais Aplicadas}

Prof $^{a}$ Dr $^{a}$ Adriana Demite Stephani - Universidade Federal do Tocantins

Prof. Dr. Álvaro Augusto de Borba Barreto - Universidade Federal de Pelotas

Prof. Dr. Alexandre Jose Schumacher - Instituto Federal de Educação, Ciência e Tecnologia de Mato Grosso

Prof $^{a}$ Dra $^{a}$ Angeli Rose do Nascimento - Universidade Federal do Estado do Rio de Janeiro

Prof. Dr. Antonio Carlos Frasson - Universidade Tecnológica Federal do Paraná

Prof. Dr. Antonio Gasparetto Júnior - Instituto Federal do Sudeste de Minas Gerais

Prof. Dr. Antonio Isidro-Filho - Universidade de Brasília

Prof. Dr. Carlos Antonio de Souza Moraes - Universidade Federal Fluminense

Prof. Dr. Constantino Ribeiro de Oliveira Junior - Universidade Estadual de Ponta Grossa

Prof $^{a}$ Dr $^{a}$ Cristina Gaio - Universidade de Lisboa

Prof $^{a}$ Dra $^{a}$ Denise Rocha - Universidade Federal do Ceará

Prof. Dr. Deyvison de Lima Oliveira - Universidade Federal de Rondônia

Prof. Dr. Edvaldo Antunes de Farias - Universidade Estácio de Sá

Prof. Dr. Eloi Martins Senhora - Universidade Federal de Roraima

Prof. Dr. Fabiano Tadeu Grazioli - Universidade Regional Integrada do Alto Uruguai e das Missões

Prof. Dr. Gilmei Fleck - Universidade Estadual do Oeste do Paraná

Prof $^{\mathrm{a}} \mathrm{Dr}^{\mathrm{a}}$ Ivone Goulart Lopes - Istituto Internazionele delle Figlie de Maria Ausiliatrice

Prof. Dr. Julio Candido de Meirelles Junior - Universidade Federal Fluminense

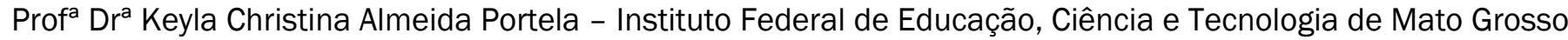

Prof $^{a}$ Dr $^{a}$ Lina Maria Gonçalves - Universidade Federal do Tocantins

Prof $^{a}$ Dr $^{a}$ Natiéli Piovesan - Instituto Federal do Rio Grande do Norte

Prof. Dr. Marcelo Pereira da Silva - Universidade Federal do Maranhão

Prof ${ }^{\mathrm{D}} \mathrm{r}^{\mathrm{a}}$ Miranilde Oliveira Neves - Instituto de Educação, Ciência e Tecnologia do Pará

Prof $^{a}$ Dr $^{\text {a }}$ Paola Andressa Scortegagna - Universidade Estadual de Ponta Grossa

Prof $^{a}{ } r^{a}$ Rita de Cássia da Silva Oliveira - Universidade Estadual de Ponta Grossa

Prof $^{a}{ } r^{a}$ Sandra Regina Gardacho Pietrobon - Universidade Estadual do Centro-Oeste

Prof $^{a}$ Dr $^{\text {a }}$ Sheila Marta Carregosa Rocha - Universidade do Estado da Bahia

Prof. Dr. Rui Maia Diamantino - Universidade Salvador

Prof. Dr. Urandi João Rodrigues Junior - Universidade Federal do Oeste do Pará

Prof $^{a}$ Dr $^{a}$ Vanessa Bordin Viera - Universidade Federal de Campina Grande

Prof. Dr. William Cleber Domingues Silva - Universidade Federal Rural do Rio de Janeiro

Prof. Dr. Willian Douglas Guilherme - Universidade Federal do Tocantins

\section{Ciências Agrárias e Multidisciplinar}

Prof. Dr. Alexandre Igor Azevedo Pereira - Instituto Federal Goiano

Prof. Dr. Antonio Pasqualetto - Pontifícia Universidade Católica de Goiás

Prof $^{a}$ Dr$^{a}$ Daiane Garabeli Trojan - Universidade Norte do Paraná

\section{贝tena


Prof $^{a}$ Dra $^{a}$ Diocléa Almeida Seabra Silva - Universidade Federal Rural da Amazônia

Prof. Dr. Écio Souza Diniz - Universidade Federal de Viçosa

Prof. Dr. Fábio Steiner - Universidade Estadual de Mato Grosso do Sul

Prof. Dr. Fágner Cavalcante Patrocínio dos Santos - Universidade Federal do Ceará

Prof $^{a}$ Dr $^{a}$ Girlene Santos de Souza - Universidade Federal do Recôncavo da Bahia

Prof. Dr. Júlio César Ribeiro - Universidade Federal Rural do Rio de Janeiro

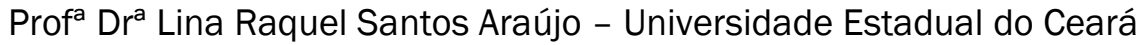

Prof. Dr. Pedro Manuel Villa - Universidade Federal de Viçosa

Prof $^{\mathrm{a}} \mathrm{Dr}^{\mathrm{a}}$ Raissa Rachel Salustriano da Silva Matos - Universidade Federal do Maranhão

Prof. Dr. Ronilson Freitas de Souza - Universidade do Estado do Pará

Prof $^{\mathrm{a}} \mathrm{Dr}^{\mathrm{a}}$ Talita de Santos Matos - Universidade Federal Rural do Rio de Janeiro

Prof. Dr. Tiago da Silva Teófilo - Universidade Federal Rural do Semi-Árido

Prof. Dr. Valdemar Antonio Paffaro Junior - Universidade Federal de Alfenas

\section{Ciências Biológicas e da Saúde}

Prof. Dr. André Ribeiro da Silva - Universidade de Brasília

Prof $^{\mathrm{a}} \mathrm{Dr}^{\mathrm{a}}$ Anelise Levay Murari - Universidade Federal de Pelotas

Prof. Dr. Benedito Rodrigues da Silva Neto - Universidade Federal de Goiás

Prof. Dr. Edson da Silva - Universidade Federal dos Vales do Jequitinhonha e Mucuri

Prof $^{a}$ Dr $^{a}$ Eleuza Rodrigues Machado - Faculdade Anhanguera de Brasília

Prof $^{a} \mathrm{Dr}^{\mathrm{a}}$ Elane Schwinden Prudêncio - Universidade Federal de Santa Catarina

Prof. Dr. Ferlando Lima Santos - Universidade Federal do Recôncavo da Bahia

Prof. Dr. Fernando José Guedes da Silva Júnior - Universidade Federal do Piauí

Prof $^{a}$ Dr $^{a}$ Gabriela Vieira do Amaral - Universidade de Vassouras

Prof. Dr. Gianfábio Pimentel Franco - Universidade Federal de Santa Maria

Prof $^{a}$ Dr $^{a}$ lara Lúcia Tescarollo - Universidade São Francisco

Prof. Dr. Igor Luiz Vieira de Lima Santos - Universidade Federal de Campina Grande

Prof. Dr. José Max Barbosa de Oliveira Junior - Universidade Federal do Oeste do Pará

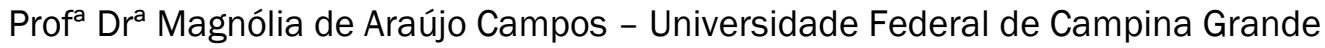

Prof $^{\mathrm{a}} \mathrm{Dr}^{\mathrm{a}}$ Mylena Andréa Oliveira Torres - Universidade Ceuma

Prof $^{a}$ Dr $^{a}$ Natiéli Piovesan - Instituto Federacl do Rio Grande do Norte

Prof. Dr. Paulo Inada - Universidade Estadual de Maringá

Prof $^{\mathrm{a}} \mathrm{Dr}^{\mathrm{a}}$ Renata Mendes de Freitas - Universidade Federal de Juiz de Fora

Prof $^{a}$ Dr $^{\mathrm{a}}$ Vanessa Lima Gonçalves - Universidade Estadual de Ponta Grossa

Prof $^{\mathrm{a}} \mathrm{Dr}^{\mathrm{a}}$ Vanessa Bordin Viera - Universidade Federal de Campina Grande

\section{Ciências Exatas e da Terra e Engenharias}

Prof. Dr. Adélio Alcino Sampaio Castro Machado - Universidade do Porto

Prof. Dr. Alexandre Leite dos Santos Silva - Universidade Federal do Piauí

Prof. Dr. Carlos Eduardo Sanches de Andrade - Universidade Federal de Goiás

Prof $^{\mathrm{a}} \mathrm{Dr}^{\mathrm{a}}$ Carmen Lúcia Voigt - Universidade Norte do Paraná

Prof. Dr. Eloi Rufato Junior - Universidade Tecnológica Federal do Paraná

Prof. Dr. Fabrício Menezes Ramos - Instituto Federal do Pará

Prof. Dr. Juliano Carlo Rufino de Freitas - Universidade Federal de Campina Grande

Prof $^{a} \operatorname{Dr}^{a}$ Luciana do Nascimento Mendes - Instituto Federal de Educação, Ciência e Tecnologia do Rio

Grande do Norte

Prof. Dr. Marcelo Marques - Universidade Estadual de Maringá

Prof $^{a}$ Dr $^{a}$ Neiva Maria de Almeida - Universidade Federal da Paraíba

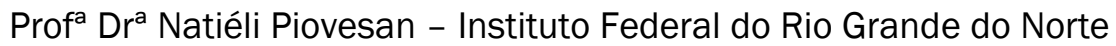

Prof. Dr. Takeshy Tachizawa - Faculdade de Campo Limpo Paulista

\section{Conselho Técnico Científico}

Prof. Me. Abrãao Carvalho Nogueira - Universidade Federal do Espírito Santo

Prof. Me. Adalberto Zorzo - Centro Estadual de Educação Tecnológica Paula Souza

Prof. Dr. Adaylson Wagner Sousa de Vasconcelos - Ordem dos Advogados do Brasil/Seccional Paraíba

Prof. Me. André Flávio Gonçalves Silva - Universidade Federal do Maranhão 
Prof $^{\mathrm{a}} \mathrm{Dr}^{\mathrm{a}}$ Andreza Lopes - Instituto de Pesquisa e Desenvolvimento Acadêmico

Prof $^{a} \operatorname{Dr}^{\mathrm{a}}$ Andrezza Miguel da Silva - Universidade Estadual do Sudoeste da Bahia

Prof. Dr. Antonio Hot Pereira de Faria - Polícia Militar de Minas Gerais

Prof ${ }^{\mathrm{a}} \mathrm{Ma}$. Bianca Camargo Martins - UniCesumar

Prof $^{a}$ Ma. Carolina Shimomura Nanya - Universidade Federal de São Carlos

Prof. Me. Carlos Antônio dos Santos - Universidade Federal Rural do Rio de Janeiro

Prof. Ma. Claúdia de Araújo Marques - Faculdade de Música do Espírito Santo

Prof. Me. Daniel da Silva Miranda - Universidade Federal do Pará

Prof $^{a}$ Ma. Dayane de Melo Barros - Universidade Federal de Pernambuco

Prof. Me. Douglas Santos Mezacas -Universidade Estadual de Goiás

Prof. Dr. Edwaldo Costa - Marinha do Brasil

Prof. Me. Eliel Constantino da Silva - Universidade Estadual Paulista Júlio de Mesquita

Prof $^{a}$ Ma. Fabiana Coelho Couto Rocha Corrêa - Centro Universitário Estácio Juiz de Fora

Prof. Me. Felipe da Costa Negrão - Universidade Federal do Amazonas

Prof $^{a}$ Dr $^{a}$ Germana Ponce de Leon Ramírez - Centro Universitário Adventista de São Paulo

Prof. Me. Gevair Campos - Instituto Mineiro de Agropecuária

Prof. Me. Guilherme Renato Gomes - Universidade Norte do Paraná

Prof $^{a}$ Ma. Jaqueline Oliveira Rezende - Universidade Federal de Uberlândia

Prof. Me. Javier Antonio Albornoz - University of Miami and Miami Dade College

Prof $^{a}$ Ma. Jéssica Verger Nardeli - Universidade Estadual Paulista Júlio de Mesquita Filho

Prof. Me. José Luiz Leonardo de Araujo Pimenta - Instituto Nacional de Investigación Agropecuaria Uruguay

Prof. Me. José Messias Ribeiro Júnior - Instituto Federal de Educação Tecnológica de Pernambuco

Prof ${ }^{a}$ Ma. Juliana Thaisa Rodrigues Pacheco - Universidade Estadual de Ponta Grossa

Prof. Me. Leonardo Tullio - Universidade Estadual de Ponta Grossa

Prof $^{a}$ Ma. Lilian Coelho de Freitas - Instituto Federal do Pará

Prof $^{a}$ Ma. Liliani Aparecida Sereno Fontes de Medeiros - Consórcio CEDERJ

Prof $^{a}$ Dr $^{a}$ Lívia do Carmo Silva - Universidade Federal de Goiás

Prof. Me. Luis Henrique Almeida Castro - Universidade Federal da Grande Dourados

Prof. Dr. Luan Vinicius Bernardelli - Universidade Estadual de Maringá

Prof $^{a}$ Ma. Marileila Marques Toledo - Universidade Federal dos Vales do Jequitinhonha e Mucuri

Prof. Me. Rafael Henrique Silva - Hospital Universitário da Universidade Federal da Grande Dourados

Prof $^{\mathrm{a}} \mathrm{Ma}$. Renata Luciane Polsaque Young Blood - UniSecal

Prof $^{a}$ Ma. Solange Aparecida de Souza Monteiro - Instituto Federal de São Paulo

Prof. Me. Tallys Newton Fernandes de Matos - Faculdade Regional Jaguaribana

Prof. Dr. Welleson Feitosa Gazel - Universidade Paulista

\begin{tabular}{|c|}
\hline $\begin{array}{c}\text { Dados Internacionais de Catalogação na Publicação (CIP) } \\
\text { (eDOC BRASIL, Belo Horizonte/MG) }\end{array}$ \\
\hline I58 Inovação, gestão estratégica e controladoria nas organizações 3 \\
[recurso eletrônico] / Organizadores Grayce Kelly Bianconi, João \\
Dallamuta. - Ponta Grossa, PR: Atena, 2020. \\
Formato: PDF \\
Requisitos de sistema: Adobe Acrobat Reader \\
Modo de acesso: World Wide Web \\
Inclui bibliografia \\
ISBN 978-65-86002-52-2 \\
DOI 10.22533/at.ed.522201703 \\
1. Controladoria. 2. Planejamento estratégico. I. Bianconi, Grayce \\
Kelly. II. Dallamuta, João. \\
CDD 658.151 \\
Elaborado por Maurício Amormino Júnior - CRB6/2422 \\
Atena Editora \\
Ponta Grossa - Paraná - Brasil \\
www.atenaeditora.com.br \\
contato@atenaeditora.com.br
\end{tabular}




\section{APRESENTAÇÃO}

Esta obra é composta por pesquisas realizadas por professores e alunos na área de gestão, todas elas selecionadas e ordenadas pelas suas contribuições genuínas e relevantes dentro dos temas propostos.

A visão ampla do gestor, além dos temas diretamente associados a seus negócios é fundamental para a sobrevivência neste ambiente mutante. Esperamos que a leitura dos trabalhos selecionados nesta obra gere reflexões e novas ideias nos leitores, razão de ser de nosso trabalho.

Os organizadores gostariam de agradecer aos autores e editores pelo espirito de parceria e confiança.

Boa leitura!

Grayce Kelly Bianconi João Dallamuta 


\section{SUMÁRIO}

CAPÍTULO 1

CIÊNCIA, TECNOLOGIA E INOVAÇÃO: DESAFIOS PARA ATUAIS E FUTUROS GESTORES

Uriel Abe Contardi

Bruno Brunelli

Grayce Kelly Bianconi

João Dallamuta

DOI 10.22533/at.ed.5222017031

CAPÍTULO 2 14

A GESTÃO DE PROCESSOS EM UMA EMPRESA DO RAMO ÓPTICO: UM ESTUDO DE CASO NUM LABORATÓRIO DE LENTES DO OESTE DE SANTA CATARINA

Cleunice Zanella

DOI 10.22533/at.ed.5222017032

CAPÍTULO 3 27

INTELIGÊNCIA EM REDE: A MELHORIA DO PROCESSO DECISÓRIO A PARTIR DA ATUAÇÃO EM REDE

Ricardo de Assis Teixeira

Danitza Passamai Rojas Buvinich

DOI 10.22533/at.ed.5222017033

CAPÍTULO 4 44

PERFIL E POTENCIAL EMPREENDEDOR DE ALUNOS INGRESSANTES DE UMA INSTITUIÇÃO FEDERAL

Fabiano Palhares Galão

Marcia Cristina Alves

Maria Gabriela Menezes

Rubem Gabriel M. da Costa

João Dallamuta

DOI 10.22533/at.ed.5222017034

CAPÍTULO 5 58

O RELATO DE CERTEAU: QUE FERRAMENTA É ESSA?

Adriana Bastos Da Costa

Franciely Chropacz

Rafael Carvalho Machado

DOI 10.22533/at.ed.5222017035

CAPÍTULO 6 65

A RELAÇÃO ENTRE INOVAÇÃO FRUGAL E SUSTENTABILIDADE: REVISÃO DE LITERATURA NA PERSPECTIVA DO TRIPLE BOTTOM LINE

Andriele Pinto de Amorim

DOI 10.22533/at.ed.5222017036

CAPÍTULO 7 79

ASPECTOS INTRÍNSECOS A SEREM CONSIDERADOS NO RELATÓRIO FINAL DE AUDITORIA INDEPENDENTE DA INFORMAÇÃO CONTÁBIL HISTÓRICA

Romeu Schvarz Sobrinho

DOI 10.22533/at.ed.5222017037 
CAPÍTULO 8 94

LA URGENCIA DE PERSPECTIVAS PLURALES EN LOS ESTUDIOS SOCIALES Y ORGANIZACIONALES

Edgar Varela Barrios

Ernesto José Piedrahita

DOI 10.22533/at.ed.5222017038

CAPÍTULO 9 107

A BARREIRA ENTRE GAYS E MERCADO DE TRABALHO: UM ESTUDO SOBRE A DISCRIMINAÇÃO DE HOMENS GAYS NO SETOR DE TELECOMUNICAÇÕES

Diogo Barros Azevedo

Luiz Eduardo Pereira Batista

Luiz Bruno de Bom da Silveira

DOI 10.22533/at.ed.5222017039

CAPÍTULO 10 121

O TRABALHO ESCRAVO CONTEMPORÂNEO COMO PRÁTICA DE GESTÃO NO BRASIL A PARTIR DA ANÁLISE DO CONTEXTO REGULATÓRIO

Herena Neves Maues Correa de Melo

Reginaldo da Motta Correa de Melo Junior

Luciana Rodrigues Ferreira

DOI 10.22533/at.ed.52220170310

CAPÍTULO 11

ORGANIZACIONES, PODER Y CULTURAS POSMODERNAS

Edgar Varela Barrios

Ernesto José Piedrahita

DOI 10.22533/at.ed.52220170311

SOBRE OS ORGANIZADORES 153

ÍNDICE REMISSIVO 154 


\section{CAPÍTULO 1}

\section{CIÊNCIA, TECNOLOGIA E INOVAÇÃO: DESAFIOS PARA ATUAIS E FUTUROS GESTORES}

serviços são relativamente simples do ponto de vista tecnológico, passam a incorporar novas características para se adequar a esta

Uriel Abe Contardi

(UTFPR) urielcontardi@alunos.utfpr.edu.br

Bruno Brunelli

(UTFPR) brunobrunelli@alunos.utfpr.edu.br

Grayce Kelly Bianconi (UNOPAR) gkbianconi@gmail.com

João Dallamuta (UTFPR) joaol@utfpr.edu.br

RESUMO: Sistemas e métodos de trabalhos de natureza tecnológica não são necessariamente uma novidade para gestores empresariais. A tecnologia da informação e automação em diferentes escalas já fazem parte do ambiente de negócios há pelo menos duas décadas. Há, porém, uma tendência tecnológica que afeta organizações em diferentes portes e segmentos que é a incorporação de características tecnológicas e inovadoras na produção de produtos e serviços, em setores não tecnológicos. Tal tendência ocorre em função da crescente competição de mercado com produtos cada vez mais globais, por novas regulamentações de natureza ambiental ou por estratégias de posicionamento de marketing de natureza sustentável ou socialmente responsável. Organizações cujos produtos e realidade, o que leva a gestão de tecnologia e inovação ao centro das atividades de gestores não familiarizados com o tema. Neste trabalho é apresentada uma revisão conceitual objetiva de três temas intimamente relacionados: ciência, tecnologia e inovação e uma visão sobre as principais atribuições da gestão de tecnologia e inovação é exposta por meio de uma metodologia de revisão bibliográfica e metodologia de pesquisa explicativa. A compreensão dos conceitos envolvidos e a apresentação das atribuições da gestão de tecnologia e inovação, fornece a formulação gestores atuantes ou em formação elementos iniciais para de políticas e processos de gestão de tecnologia e inovação, sobretudo em organizações não tecnológicas onde o tema não é usual.

PALAVRAS CHAVE: Tecnologia, Inovação, Gestão

\section{SCIENCE, TECHNOLOGY AND INNOVATION, CHALLENGES FOR CURRENT AND FUTURE MANAGERS}

ABSTRACT: Systems and methods of technological work are not new to business managers. Information technology and 
automation at different scales have been part of the business environment for at least two decades. However, there is a technological trend that affects organizations of different sizes and segments, which is the incorporation of technological and innovative characteristics in the production of products and services in non-technological sectors. This trend is due to increasing market competition with increasingly global products, new environmental regulations, or sustainable or socially responsible marketing positioning strategies. Organizations whose products and services are relatively simple from the technological point of view, incorporate new features to suit this reality, which brings technology management and innovation to the center of activities of managers unfamiliar with the topic. This paper presents an objective conceptual review of three closely related themes, science, technology and innovation, and an insight into the main attributions of technology management and innovation management is presented through a literature review methodology and explanatory research methodology. Understanding the concepts involved and presenting the attributions of technology and innovation management provides initial or training managers with initial elements for the formulation of technology and innovation management policies and processes, especially in non-technological organizations where the theme is unusual.

KEYWORDS: Technology, Innovation, Management

\section{I INTRODUÇÃO}

Em uma sociedade que se inventa e reinventa a cada instante, a concorrência e a mudança do mercado exigem dinamicidade e inovação, o que Schumpeter (1942) define como destruição criadora.

Nas organizações do setor tecnológico, a teoria da destruição criadora é vivenciada e presente, uma vez que a capacidade de inovação é algo intrínseco para sua sobrevivência e crescimento. Já os setores mercadológicos que ofertam serviços ou produtos relativamente simples, a gestão tecnológica e de inovação ainda são incipientes. No entanto, num universo de alta competitividade agregada às interferências das regulamentações ambientais e as estratégias de posicionamento de marketing de natureza sustentável, a temática da gestão tecnológica e de inovação é uma necessidade urgente e primordial a fim de permitir sua sobrevivência na contemporaneidade.

Exemplificasse o supracitado com a lei do estado de São Paulo (Lei $N^{\circ} 17.110$, de 12 de Julho de 2019) que vedou o uso de canudos plásticos em estabelecimentos comerciais, apesar do processo não exigir uma alta complexidade tecnológica, as organizações de canudos plásticos necessitam aplicar o uso da gestão de tecnologia e de inovação para se adaptarem as regras e continuarem no mercado. "Novas legislações que visam controlar processos ou estabelecer exigências técnicas podem oportunizar o desenvolvimento de inovações destinadas a suprir estas novas necessidades" (JUNG,2004, p.35).

Dessa forma o presente artigo apresenta os temas mais relevantes para 0 
mercado atual: ciência, tecnologia e inovação, além disso é relatado a importância da gestão tecnológica e inovação para organizações não tecnológicas e por fim possibilita aos gestores atuantes ou em formação, entendimento inicial para a formulação de ideias acerca da gestão da tecnologia e inovação em seu campo de atuação.

\section{I REFERENCIAL TEÓRICO}

\subsection{Definição de Ciência}

De acordo com Jung (2004) ciência é o ato de adquirir conhecimento de forma sistemática, ou seja, por meio de métodos, proporcionando resultados mais exatos e assertivos visando uma melhora na qualidade de vida, intelectual e material, além disso os objetos de estudo da ciência são todos os fenômenos relacionados a natureza social, biológica e tecnológica.

No entanto, primordialmente a busca pelo conhecimento muitas vezes era desvinculada de objetivos práticos, buscava-se entender e compreender os fenômenos físicos e universalizar o conhecimento por meio de leis e teoremas. Este tipo de ciência é classificado como "Pura" e tem por objetivo obter os conhecimentos básicos e fundamentais, não existindo uma preocupação pelo que o conhecimento possa gerar.

Todavia esta classe mesmo presente na modernidade não é a principal, a abordagem mudou ao longo do tempo, o principal foco da ciência no mundo contemporâneo está em realizar novas descobertas com a finalidade de transformar estes novos conhecimentos em algo "comercializável”, ou seja, a produção de produtos ou serviços que possibilitem a melhoria na qualidade de vida, esta parte da ciência é classificada como "Aplicada". Tanto a ciência pura ou aplicada necessita, de formas de aquisição de conhecimentos para a produção e validação de conhecimentos científicos que são: intuição, empirismo e racionalismo.

O conhecimento por meio da intuição é subjetivo a cada ser humano, uma vez que cada um possui uma percepção dos fenômenos; o empirismo, por sua vez baseiase na ideia de que o conhecimento é gerado somente pela experiência e testes e o racionalismo afirma que o conhecimento somente pode ser adquirido por meio da razão pois apenas testes e experimentações podem gerar enganos.

Embora apresentem distinções, intuição, empirismo e racionalismo se complementam: a intuição é responsável pelo surgimento de ideias, inovações e invenções, por sua vez o empirismo é o responsável por realizar os testes e experimentações da ideia e por fim deve-se validar este conhecimento por meio do racionalismo, como bem representa Jung (2004) na Figura 01. 


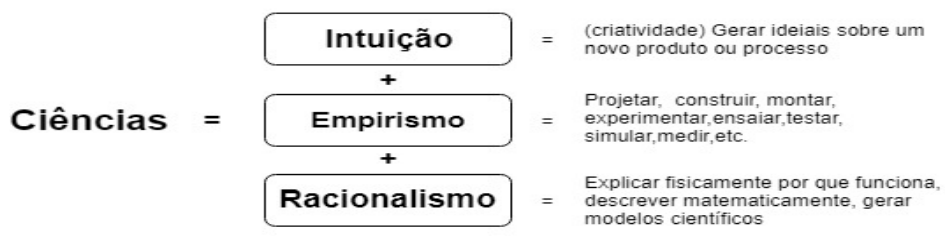

Figura 01: Requisitos para a efetividade científica. Fonte: (JUNG, 2004).

\subsection{Tecnologia}

Para Mattos e Guimarães (2012), tecnologia é o conjunto organizado dos conhecimentos científicos, empíricos ou intuitivos, considerada como a ciência aplicada que desenvolve constantemente novos métodos, técnicas e produtos a fim de otimizar e melhorar os processos, reduzir o esforço humano, melhorar a qualidade de vida e viabilizar a inovação de novos produtos.

Nos últimos tempos o ser humano tem realizado muitas conquistas científicas e tecnológicas: a descoberta de penicilina, advento da internet, desenvolvimento do smartphone, desenvolvimento de foguetes espaciais; estas são apenas algumas das conquistas efetivadas devido a ciência e tecnologia (C\&T), toda essa dinâmica da C\&T também afetou o sistema de produção, bem como a competitividade do mercado. Todos setores atualmente de alguma forma acabam sendo influenciados pelas novas tecnologias, a automação por exemplo era um sistema que somente era visto no setor industrial, contudo, com a evolução e viabilização ela é encontrada em casas inteligentes ou escritórios; a agricultura por sua vez é impactada pela biotecnologia na produção de plantas geneticamente melhoradas; assim, de uma forma geral, a C\&T tornou-se algo que a sociedade é dependente e este fato só tende a se tornar mais presente.

É oportuno destacar que a tecnologia não se encontra unicamente em aparatos de alta complexidade (JUNG,2004, p.26), mas também em objetos do cotidiano como é o caso da produção de plásticos e tecidos, comprovando que todos os setores necessitam em algum momento do desenvolvimento de tecnologias.

A produção tecnológica advém de centros de pesquisas e desenvolvimento de empresas e instituições de ensino superior, tecnológico ou técnico, estas pesquisas realizadas seguem o modelo de pesquisa básica científica, contudo tem por finalidade o mercado. A ordem hierárquica de processo de geração de conhecimento para o mercado é ilustrada na Figura 02. 


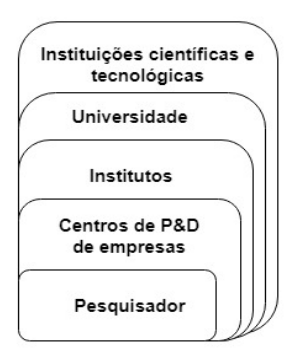

Figura 02 - Ordem da transferência tecnológica. Fonte: (MATTOS \& GUIMARÃES, 2012)

Ao que se diz respeito ao ciclo das tecnologias pode-se citar a Curva S proposta por Foster (1986), a Figura 03 ilustra o modelo, é possível visualizar que o desempenho de uma tecnologia em sua fase inicial aumenta a uma taxa muito lenta, posteriormente o desempenho cresce de forma exponencial e na fase seguinte estagna por alcançar seus limites técnicos alcançando a maturidade.

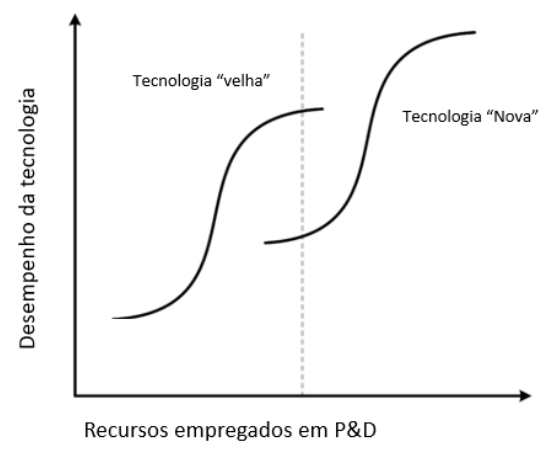

Figura 03 - Curva S. Fonte: (FOSTER,1988).

No momento em que o desempenho tecnológico de começa a crescer rapidamente normalmente surge uma nova curva substituta que apresenta um futuro mais promissor, que será mais dominante uma vez que apresenta um novo modelo que é mais aceito pelo mercado e atende melhor as necessidades dos clientes, o mercado então simplesmente abandona o menos eficiente e muda para a nova curva, o ciclo repete-se então e cada tecnologia é trocada por uma outra que atenderá melhor o mercado. Pode-se exemplificar tecnologias que estão na fase inicial da curva S: drones, loT (Internet das coisas), criptomoedas e inteligência artificial, pois mesmo possuindo potencial para transformar o mercado ainda não foram totalmente exploradas.

\subsection{Inovação}

Para Schumpeter (1942) inovação é algo novo que efetivamente mudará o mercado, o que se difere da invenção, uma vez que esta última possui apenas potencial para fins comerciais, mas não necessariamente causará algum impacto. De forma geral pode-se dizer que a inovação é a soma da invenção com comercialização.

De acordo com Mattos e Guimarães (2012) estes fatores são: fluxo de informações 
entre pessoas, a receptividade a mudanças e a disponibilidade de capital. Porter (1986) também descreve que as organizações devem determinar seus limites externos e aprender a competir, melhorando independentemente das mudanças.

Apesar do conceito de inovação estar atualmente intrinsicamente relacionado ao desenvolvimento da tecnologia, inovar não está somente relacionada na criação de produtos revolucionários que utilizam um alto grau de complexidade tecnológica, a simples substituição de um material que seja economicamente mais viável pode ser considerado uma inovação, dessa forma o conceito de inovação é muito abrangente.

Segundo o Manual de Oslo (2006), documento criado pela Organização para a Cooperação e Desenvolvimento Econômico (OCDE) a fim de orientar e padronizar o P\&D, a inovação pode ser classificada em: inovação de produto, de processo, de marketing e organizacional.

A inovação de produto é a criação de um novo bem ou serviço que possua um aperfeiçoamento no que se diz respeito a suas características ou uso, podendo ser utilizado novas tecnologias ou combinações delas no processo de criação do produto, ressalta-se que pequenas modificações já são consideradas inovações de produtos.

Resultados significativos podem ocorrer por meio da mudança de materiais e componentes, um novo tipo de plástico ou polímero mais resistentes na produção de peças no setor automotivo, ou ainda o desenvolvimento de tecidos que permitam a transpiração são exemplos de inovação de produto. A inovação de processo trata-se de uma mudança no método de fabricação de um bem, não necessariamente gera um impacto no produto final, mas produz benefícios para o processo, como o aumento da produtividade e qualidade, redução de custos e de tempo.

Pode-se exemplificar como inovação de processo a utilização da automação em uma linha de produção, aperfeiçoamento do sistema de logísticas e uso de software para gerenciamento dos processos. A inovação de marketing ocorre com a implementação de um novo método de marketing e este deve trazer mudanças significativas, visando aumentar as vendas e melhor atender à necessidade dos consumidores.

Estratégias que interfiram na produção do produto ou em sua embalagem, posicionamento do produto, promoção ou fixação de preços são exemplos de estratégias de marketing com a finalidade de inovar.

A inovação organizacional é a implementação de um novo modelo de negócios ou de estrutura, a organização do local de trabalho ou ainda a mudança da relação com o mercado, cliente e fornecedores. Mudanças como o compartilhamento de informações dentro de uma organização, para uma comunicação mais eficaz dos setores, a redistribuição de tarefas permitindo maior autonomia para cada profissional são exemplos de inovações organizacionais e fazem todo diferença no processo.

Por fim ainda pode-se perguntar quanto inovador algo é para a sociedade, surgindo então a necessidade de classificar o grau da inovação, buscando-se medir o impacto que algo causará dentro de uma empresa ou no mercado em geral, segundo De Bes e Kotler (2011) os graus de inovação do menor para o maior: incremental, 
radical e disruptiva.

Uma inovação incremental caracteriza-se pela inovação em produtos ou serviços já existentes, melhorando ou reconfigurando uma tecnologia existente para outros fins, o aumento da escala de produção, diminuição de perdas ou aumento da eficiência devido a mudanças no processo são exemplos de uma inovação incremental.

A inovação radical por sua vez é aquela que resulta na criação de uma nova invenção, cujas características sejam diferentes comparado ao que já existe, pode estar associado a uma nova tecnologia ou na combinação de tecnologias existentes, sendo capaz de criar novos mercados, como é o caso do celular que criou uma nova linha de negócios para as empresas, e ainda posteriormente criou o mercado de aplicativos.

O último grau de inovação e mais impactante é a inovação disruptiva ou revolucionária, trata-se de uma inovação radical que causa um grande impacto no mercado não restringindo-se apenas a criação de um novo produto, podendo ser uma ideia, simples, mais barata e prática, criando uma nova rede de mercado e valor e eventualmente interrompendo outra rede de valor, movendo toda dinâmica do mercado, pode-se citar como exemplo a Netflix que mudou a maneira de consumir conteúdo, acabando com o mercado de locadoras e ameaçando por exemplo as emissoras de Televisão. A Figura 04 ilustra a matriz com os graus de inovação, tendo como variáveis a tecnologia e modelo de negócio.

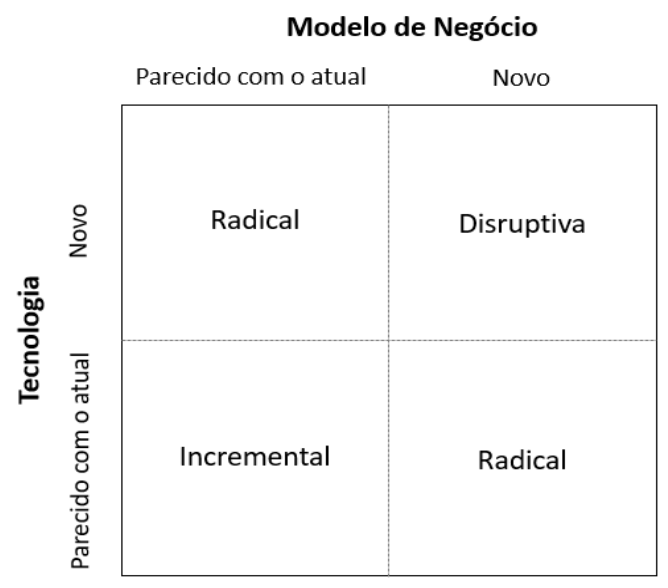

Figura 04 - Matriz dos graus de inovação. Fonte: (DE BES \& KOTLER,2011).

\subsection{Gestão da Tecnologia e Inovação}

Vasconcellos et al (1994) define a gestão tecnológica como o uso da administração com o objetivo de garantir que a tecnologia seja utilizada com maior efetividade para o apoio e sustentação dos objetivos da organização.

Para Mattos e Guimarães (2012) a gestão tecnológica inclui todas competências para capacitar uma organização, coordenando a Pesquisa e Desenvolvimento (P\&D), a engenharia e o gerenciamento para planejar, desenvolver e possibilitar o melhor uso 
das capacidades tecnológicas, a fim de promover a evolução de uma organização.

Ambas definições afirmam que os gestores devem saber lidar com as tecnologias envolvidas nos processos que cabem a suas empresas, todavia a quantidade de tecnologia utilizada atualmente muitas vezes é enorme, sendo assim os gestores devem investir tempo aprendendo sobre as tecnologias críticas e fundamentais de sua empresa e também buscar fontes de consultorias técnicas que possam auxiliá-los ao que se diz respeito a tecnologias mais complexas (MATTOS E GUIMARÃES, 2012, p.61).

Ressalta-se ainda o modelo proposto por Valeriano (1998) da atuação da gestão da tecnologia e inovação em empresas, evidenciado na Figura 05, em que se mostra como a gestão da tecnologia e inovação realiza a conexão entre os setores da pesquisa e desenvolvimento com a empresa, ou seja, o mercado.

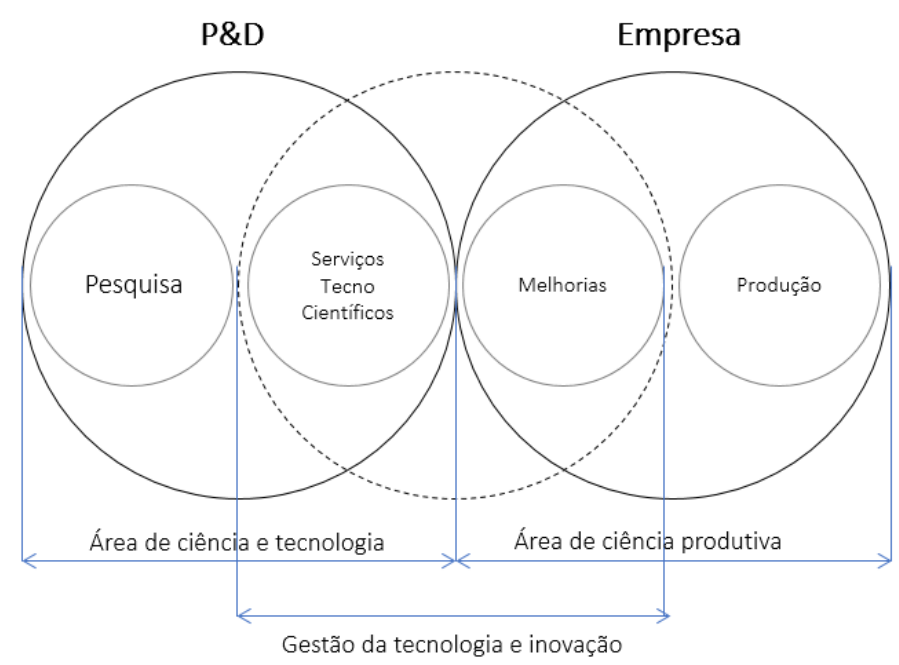

Figura 05 -. Definição da atuação da gestão da tecnologia e inovação. Fonte: (VALERIANO,1998).

Mas, por que inovar? Para Morin e Seurat (1998) as empresas possuem a facilidade de reconhecer que a tecnologia é um elemento essencial para a competitividade, todavia, a maioria não aplica uma gestão coerente e eficiente dos seus recursos tecnológicos e isso se deve ao fato de não enxergarem a tecnologia como um recurso a ser gerido, ou pelo desconhecimento das tecnologias envolvidas no próprio negócio.

Além disso estudos apontam relação da gestão tecnológica com a evolução de organizações, pode-se citar: estudo realizado por Lowell W. Steele (1988) mostraram que a existe uma correlação entre o investimento em pesquisa e desenvolvimento (P\&D), o lucro e a frequência de lançamento de novos produtos, ou ainda o Gerard H. Gaynor (1996) que revela a forte relação entre o desempenho econômico de uma empresa com o investimento em inovação tecnológica.

A Figura 06 ilustra uma visão global do investimento em pesquisa e desenvolvimento feita por cada região. 

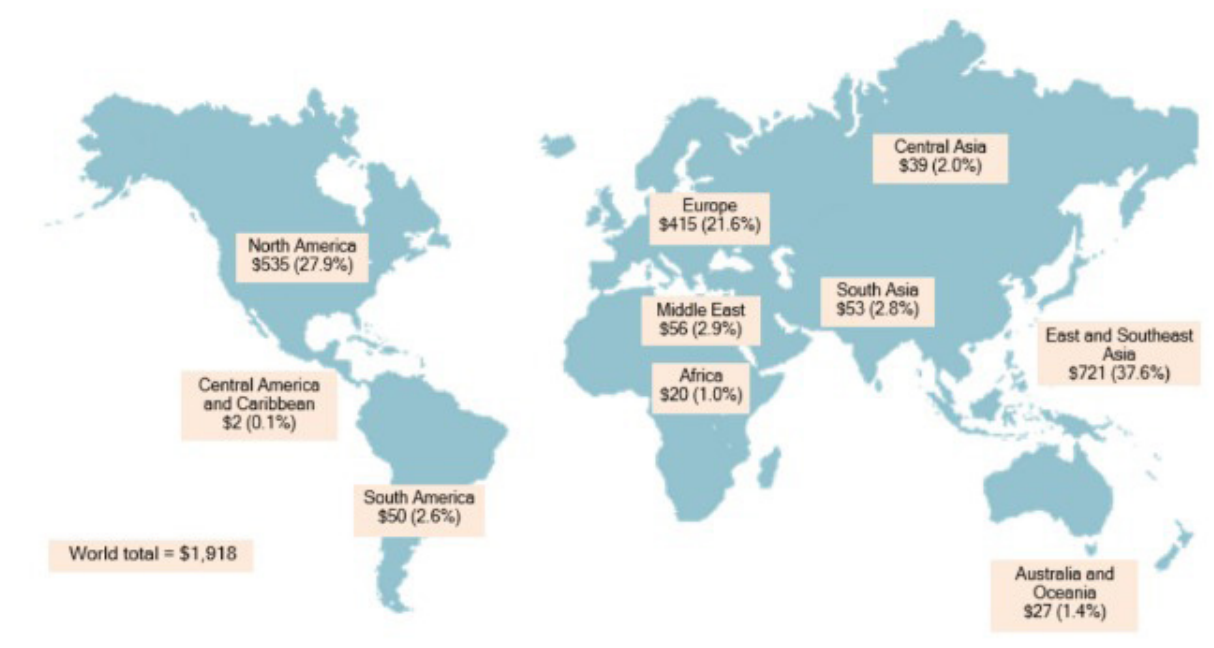

(em bilhões de USS corrente de PPC)

Figura 06: Investimento global em Pesquisa e Desenvolvimento (2015).

Fonte: Science and Engeneering Indicators 2018, National Science Foundatiojn, EUA.

No ano de 1968, Sábato e Botana propuseram uma abordagem que ficaria conhecida como Triângulo de Sábato. Neste modelo três atores são fundamentais para o desenvolvimento social: o governo, a estrutura produtiva e a estrutura científica e tecnológica (SÁBATO; BOTANA, 1968). Baseado no modelo de Sábato e Botana, o conceito da Tríplice Hélice, foi proposto na década de 90 por Etzkowitz e Leydesdorff (1995), mantendo a proposta de interação dos elementos universidade-governoempresa como impulsionadores da inovação. Para estes autores o modelo da Tríplice Hélice a universidade é a instituição central do setor do conhecimento e promotora das relações entre o setor produtivo e o governo, levando a universidade a produzir novos conhecimentos, fomentar a inovação tecnológica e incorporar novas funções no desenvolvimento econômico. Tal modelo quando bem executado pelos atores promove o ambiente propicio para a inovação.

Embora não seja o único, a requisição de patentes é um dos mais claros indicadores da atividade de desenvolvimento tecnológico e inovador de nações ou organizações. A figura 7 ilustra a comparação do Brasil com outras doze nações para o ano de 2011. 


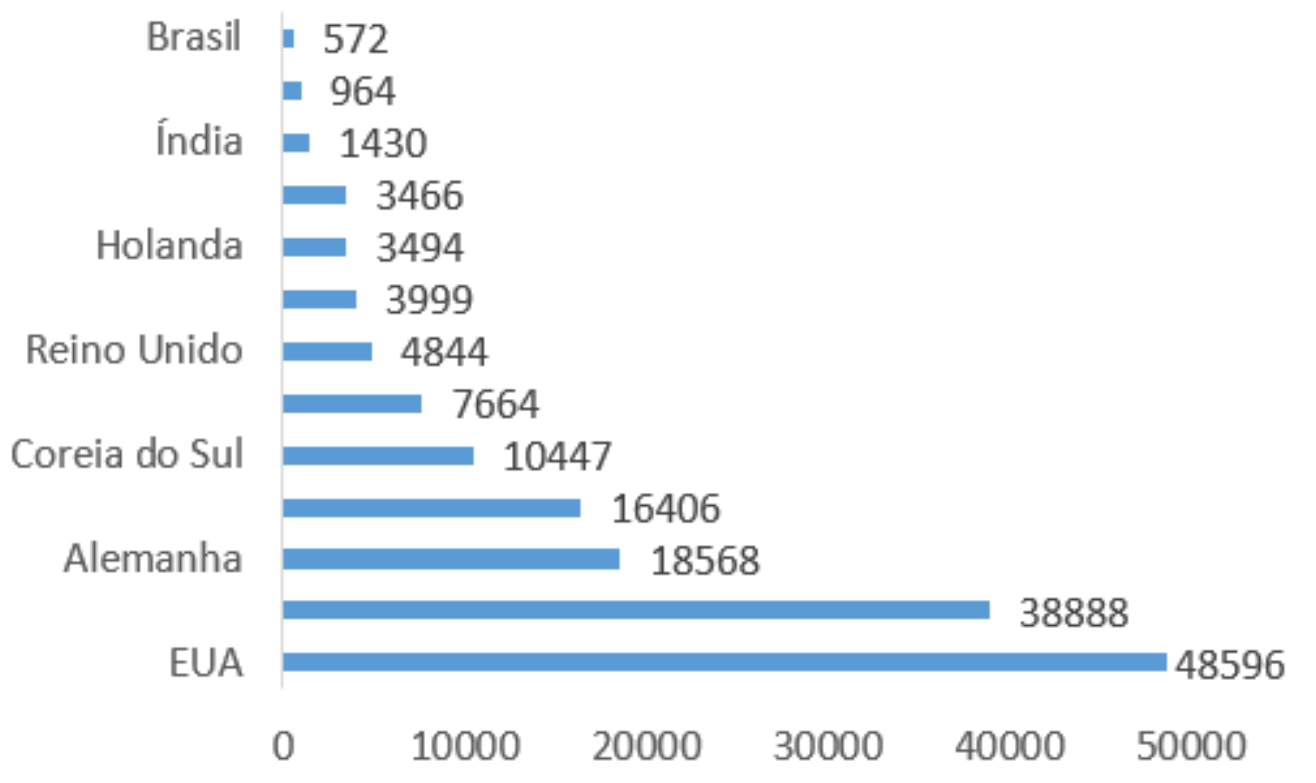

Figura 07: Pedidos de patentes por países em 2011

Fonte: 2012 PCT Yearly Review / WIPO Word Intellectual Property Organization

Um aspecto fundamental da gestão da inovação é a proteção intelectual, é por meio dela que o resultado do esforço de inovação vai ser protegido legalmente. A Convenção que institui a Organização Mundial da Propriedade Intelectual foi assinada em Estocolmo em 14 de julho de 1967, posteriormente modificada em 28 de setembro de 1979, o documento define propriedade intelectual como; A soma dos direitos relativos às obras literárias, artísticas e científicas, às interpretações dos artistas intérpretes e às execuções dos artistas executantes, os fonogramas e às emissões de radiodifusão, às invenções em todos os domínios da atividade humana, às descobertas científicas, aos desenhos, e modelos industriais, às marcas industriais, comerciais, e de serviço, bem como às firmas comerciais e denominações comerciais, à proteção contra concorrência desleal e todos os outros direitos inerentes à atividade intelectual nos domínios industrial, científico, literário e artístico.

No Brasil o marco legal sobre o tema, está na constituição federal vigente, promulgada em 1988, no seu artigo 50 que trata dos "Direitos e Garantias Fundamentais", inciso XXIX. A lei assegurará aos autores de inventos industriais privilégio temporário para sua utilização, bem como proteção às criações industriais, à propriedade das marcas, aos nomes de empresas e a outros signos distintivos, tendo em vista $o$ interesse social e o desenvolvimento tecnológico e econômico do País.

No Brasil o registro de propriedade industrial, é responsabilidade do Instituto Nacional da Propriedade Industrial (INPI), uma autarquia federal vinculada ao Ministério da Economia. Para o INPI patente é definida como um título de propriedade temporária sobre uma invenção ou modelo de utilidade, outorgado pelo Estado aos inventores ou autores ou outras pessoas físicas ou jurídicas detentoras de direitos 
sobre a criação. Com este direito, o inventor ou o detentor da patente tem o direito de impedir terceiros, sem o seu consentimento, de produzir, usar, colocar à venda, vender ou importar produto objeto de sua patente e/ ou processo ou produto obtido diretamente por processo por ele patenteado. Em contrapartida, o inventor se obriga a revelar detalhadamente todo o conteúdo técnico da matéria protegida pela patente.

\section{I PROCEDIMENTOS METODOLÓGICOS}

A pesquisa tem como proposito a sensibilização da importância do tema entre gestores, sejam os atuantes ou em formação, bem como a definição de conceitos fundamentais sobre o assunto de forma estruturada.

Os procedimentos metodológicos para esta pesquisa classificam-se como: pesquisa exploratória, em uma abordagem do problema de enfoque qualitativo, já os procedimentos técnicos utilizados basearam-se na busca de dados secundários, sendo utilizada para isto pesquisa bibliográfica e documental sobre o tema.

\section{I CONSIDERAÇÕES FINAIS}

Diante da importância da tecnologia para a sociedade contemporânea e da inovação para os setores comerciais, no que se diz respeito a manter a competitividade, espera-se que o presente artigo tenha possibilitado aos leitores o entendimento sobre as questões conceituais relacionadas à tecnologia, ciência e inovação evidenciando ainda a importância da gestão da tecnologia e inovação para todos os setores, até mesmo para aqueles que não estão diretamente relacionados ao setor tecnológico.

Em outro momento o presente artigo ainda categorizou os tipos e graus de inovação, explanou sobre a atuação da gestão da tecnologia nas empresas, possibilitando um melhor entendimento para aqueles que fazem gestão ou interessados pela área, mostrando de uma maneira geral acerca dos temas que envolvem a gestão da tecnologia e inovação.

De acordo com os diversos autores citados ao longo do texto pode-se ainda perceber que a todo momento o mercado passa por mudanças e o que dita o caminho que o mesmo irá seguir são por vezes as inovações, dessa forma as empresas necessitam investir e criar planos de negócios voltados para o desenvolvimento de novas tecnologias que possibilitem destacar-se no mercado, principalmente no âmbito nacional, onde alguns indicadores mostraram ainda como é escasso o investimento em P\&D nas organizações.

O intuito foi organizar as informações sobre o assunto, criando uma linha lógica de aprendizado, de modo a permitir aos leitores a busca e reflexão sobre o tema, estimulando a abordagem de novos caminhos para que então seja possível adquirir novos conhecimentos relacionados a gestão da tecnologia e inovação. 


\section{REFERÊNCIAS}

AAKER, David A. Pesquisa de marketing. 2. ed. São Paulo: Atlas, 2004.

BES, F. T.; KOTLER, P. A Bíblia da Inovação. São Paulo: Leya, 2011

BRASIL. [Constituição (1988)]. Constituição da República Federativa do Brasil: promulgada em 5 de outubro de 1988. 4. ed. São Paulo: Saraiva, 1990.

BRASIL. Ministério da Agricultura, Pecuária e Abastecimento. Empresa Brasileira de Pesquisa Agropecuária. Gestão da inovação tecnológica: empreendedorismo e geração de tecnologia em instituições de pesquisa. Editores técnicos Guarany Carlos Gomes e Ana Lucia Atrasas. Brasília: Embrapa, 2006. 60 p. (Documentos, 4).

Convenção que institui a Organização Mundial da Propriedade Intelectual. Texto oficinal em português, disponível em; https://www.wipo.int/edocs/pubdocs/pt/wipo_pub_250.pdf. Acessado em 07/09/2019. às $15 \mathrm{~h} 55$.

ETZKOWITZ, H. Innovation in Innovation: The Triple Helix of University-Industry-

Government Relations. Social Science Information, v. 42, n. 3, p. 293-337, 2003.

FOSTER, Richar. Inovação - A vantagem do Atacante. São Paulo: Editora Best Seller, 1988

GAYNOR, G. H. Handbook of technology management. Nova York: McGraw-Hill, 1996.

INPI, Definição de Patentes. Disponível em: http://www.inpi.gov.br/servicos/perguntas-frequentespaginas-internas/perguntas-frequentes-patente\#patente acessado em 07/09/2019 às 16h12

JUNG, C.F. Metodologia para pesquisa \& desenvolvimento. Rio de Janeiro: Axcel Books do Brasil, 2004.

MATTOS, J.R.L., \& Guimarães, L.S. Gestão da tecnologia e inovação: uma abordagem prática. São Paulo: Saraiva,2012.

MORIN, Jacques e SEURAT, Richard. Gestión de los Recursos Tecnológicos. COTEC: Madrid, 1998.

OCDE. Manual de Oslo: diretrizes para a coleta e interpretação de dados sobre inovação tecnológica. Publicada pela FINEP (Financiadora de Estudos e Projetos), $3^{a}$ Edição,2006.

PORTER, M. (1986). Estratégia competitiva: técnicas para análises de indústrias e da concorrência. $7^{\mathrm{a}}$ edição. Rio de Janeiro: Campus.

Revisão Anual PCT 2012. O Sistema Internacional de Patentes. Disponível em https://www.wipo.int/ edocs/pubdocs/en/patents/901/wipo_pub_901_2012.pdf. Acessado em 09/09/2019. Às 23h58.

SÃO PAULO. Lei $\mathrm{N}^{\circ} 17.110$, de 12 de Julho de 2019. Proíbe o fornecimento de canudos confeccionados em material plástico no Estado e dá outras providências. São Paulo: Alesp, [2019]. Disponível em: https://www.al.sp.gov.br/norma/?id=191082. Acesso em: 01 set. 2019.

SCHUMPETER, J. A. Capitalismo, sociedade e democracia. Rio de Janeiro: Zahar, 1948. 
STEELE, Lowell W. Managing technology: the strategic view. Nova York: McGraw-Hill, 1988.

VALERIANO, D. L. Gerência de projetos: pesquisa, desenvolvimento e engenharia. São Paulo: Makron Books, 1998.

VASCONCELLOS, Eduardo. BERMAN, Evan. WERTHER, Willian. Estratégia Tecnológica no Brasil, Japão e EUA: um estudo comparado. In: Anais do XVIII Simpósio de Gestão da Inovação Tecnológica. São Paulo: USP/NPGCT/FIA/PACTo, 1994, p.235-246. 


\section{CAPÍTULO 2}

\section{A GESTÃO DE PROCESSOS EM UMA EMPRESA DO RAMO ÓPTICO: UM ESTUDO DE CASO NUM LABORATÓRIO DE LENTES DO OESTE DE SANTA CATARINA}

Data de aceite: 11/03/2020

Data de submissão: 09/12/2019

Cleunice Zanella

Universidade Comunitária da Região de Chapecó - UNOCHAPECÓ

Chapecó - SC http://lattes.cnpq.br/3448181336056859

RESUMO: O estudo e aperfeiçoamento dos processos de produção devem ser constantes, visando a melhoria contínua e, como consequência a competitividade e permanência das empresas no mercado. A partir deste contexto, este estudo teve como principal objetivo propor melhorias para o processo produtivo de lentes oftálmicas, especialmente na linha de lentes Ig Soft ${ }^{\circledR}$ na Iguaçu Distribuidora de Produtos Óticos. Trata-se de um estudo de caso com abordagem qualitativa e descritiva. A coleta de dados foi realizada através de entrevistas com os gestores da empresa, bem como aplicação de questionário para todos os funcionários. Como principais resultados, destaca-se a elaboração do fluxograma dos processos de produção, identificação de perdas ao longo das etapas, bem como proposições de melhorias de curto, médio e longo prazo, destacando-se a padronização dos processos como uma das principais proposições.

PALAVRAS-CHAVE: Gestão de processos, padronização de processos, redução de perdas.

PROCESS MANAGEMENT IN AN OPTICAL COMPANY: A CASE STUDY IN A SANTA CATARINA WEST LENS LABORATORY

ABSTRACT: The study and improvement of the production processes must be constant, aiming at the continuous improvement and, as a consequence, the competitiveness and permanence of the companies in the market. From this context, this study had as main objective to propose improvements for the ophthalmic lens production process, especially in the Ig Soft ${ }^{\circledR}$ lens line in Iguaçu Distributor of Optical Products. This is a case study with qualitative and descriptive approach. Data collection was performed through interviews with company managers, as well as the application of a questionnaire to all employees. The main results are the production process flowchart elaboration, loss identification along the steps, as well as short, medium and long term improvement propositions, highlighting the process standardization as one of the main propositions.

KEYWORDS: Process management, process 


\section{I INTRODUÇÃO}

Diante das mudanças constantes que ocorrem no ambiente de atuação das organizações (MARTINS; GUINDANI, 2013), a gestão de processos assume papel importante, independente do ramo em que atuam, se são privadas ou públicas. Quanto maior for a complexidade do trabalho por meio do sistema produtivo, maior é a necessidade da capacidade em gerir processos. Tal capacidade pode se tornar uma forma eficaz de promover integração, dinâmica, flexibilidade e inovação nas organizações. Além de promover uma paridade e/ou vantagem competitiva, pode proporcionar alguns benefícios como: melhoria do fluxo de informações; padronização de processos; redução de tempo e custos dos processos; aumento da produtividade dos trabalhadores; redução de defeitos; entre outros (PAIM et al, 2009).

Gerir processos pode ser entendido como uma forma de reduzir o tempo entre o reconhecimento de um problema de desempenho nos processos e a realização das soluções necessárias. Para que isso aconteça, é preciso estruturar as ações de modelagem e análise para que os problemas sejam rapidamente diagnosticados e solucionados, promovendo instalações com menores intervalos de tempo e custos possíveis (PAIM et al, 2009).

Muitas empresas utilizam de um mesmo processo por muito tempo, sem a intenção de mudar, pois, inovar ou melhorar novos processos e produtos pode ser um desafio. Porém, se houver uma visão holística e planejamento é possível aprimorar o que já está apresentando resultados positivos. Segundo Wildauer (2015), aperfeiçoamento de processo indica uma melhoria na qualidade de execução do mesmo, realizando intervenções que venham a gerar mudanças que aumentem a qualidade produtiva.

Este trabalho teve como tema a gestão de processos em uma empresa do ramo óptico, que fabrica e distribui lentes oftálmicas. Empresas deste segmento possuem uma demanda específica, que precisa de lentes produzidas conforme suas necessidades, gerando a produção por encomenda. Além disso, cada consumidor tem necessidades diferentes, gerando assim, uma infinidade de modelos e marcas que competem no mercado.

\section{I GESTÃO DE PROCESSOS}

A gestão ou administração da produção está diretamente relacionada às atividades de gerenciamento estratégico dos recursos que determinada empresa possui (CORRÊA, CORRÊA, 2012; KRAJEWSKI, RITZMAN, MALHOTRA, 2009). Também pode ser entendida como um processo de tomada de decisão (MOREIRA, 2000).

Shingo (1996), traz uma visão sobre produção onde a define como uma rede de 
processos e operações. Para o autor, um processo é visto como um fluxo de materiais no tempo e no espaço, ou seja, é a realização de uma etapa, como a transformação da matéria prima em produto acabado. Já as operações, podem ser exemplificadas como sendo o trabalho efetuado na realização dessa transformação.

Quando pensa-se na importância dos processos para as organizações, Wildauer e Wildauer (2015), apontam que os processos são responsáveis pelo desenvolvimento e sustentação das estratégias para a organização. Contador (1998) afirma que, para realizar qualquer modificação ou melhoria nos processos existentes na organização, primeiramente, é necessário desenvolver uma análise do processo atual. A análise dos processos pode ser entendida, de acordo com Krajewski, Ritzman e Malhotra (2009), como uma documentação e compreensão detalhada de como o trabalho está sendo realizado e de como pode ser reformulado.

Conforme Ballestero-Alvarez (2012), para uma organização ser competitiva, precisa identificar e gerenciar seus processos de forma adequada e cuidadosa, levando em consideração a interdependência entre eles, pois, quando determinado processo é realizado de forma inadequada, compromete os demais, podendo acarretar em perdas.

As perdas, segundo Shingo (1996), são quaisquer atividades que não contribuem para as operações. As operações, por sua vez, podem ser classificadas de duas maneiras: as que agregam e as que não agregam valor.

As que agregam valor são as operações que transformam realmente a matéria prima, alterando a forma e a qualidade, enquanto as operações que não agregam valor são consideradas perdas (SHINGO, 1996). A redução de perdas consiste em realizar a análise de todas as operações executadas na fábrica e suspender aquelas que não agregam valor à produção (CORRÊA, CORRÊA, 2012). Baseando-se no Sistema Toyota de Produção, é possível identificar sete tipos de perdas elencadas por Shingo (1996), as sete perdas são: 1) superprodução; 2) espera; 3) transporte; 4) processamento; 5) estoque; 6) desperdício nos movimentos; e, 7) o desperdício na elaboração de produtos defeituosos. As sete perdas também são identificadas por Antuns (2008), Correa e Correa (2012).

Existem mais dois desperdícios evidenciados por outros autores. Em seu livro, Liker (2005) estabeleceu uma oitava perda, o desperdício da criatividade dos funcionários, que significa a perda de tempo, ideias, habilidades, melhorias e oportunidades de aprendizagem quando não há envolvimento ou os funcionários não são ouvidos pelos gestores. Já Machado e Tondolo (2014), em sua pesquisa, indicaram a existência de uma nona perda, por ruptura de gôndola. Essa perda gera "[...] uma situação que atinge tanto o varejo como a indústria na medida em que afeta diretamente o relacionamento com os consumidores gerando insatisfação e expondo as ineficiências operacionais" (MACHADO; TONDOLO, 2014, p. 26).

Uma das alternativas para redução de perdas é a análise dos processos para posterior padronização. Segundo Cavanha Filho (2006), a padronização visa a redução de erros e desvios no processo produtivo, através de atividades como: normalizar; 
reduzir; esquematizar; induzir a todos os mecanismos de economia; e, redução de dispersão.

De maneira mais ampla, deve-se ter consciência de que nas organizações se faz necessário envolver a avaliação dos procedimentos estabelecidos. Ou seja, é preciso implantar um sistema de padronização que inclua a criação, a disseminação, o treinamento, a avaliação do uso e dos resultados dos padrões estabelecidos, como também a sua constante atualização (BARROS, BONAFINI (Orgs.), 2014).

Em ambientes produtivos industriais, existem três tipos de padronização, segundo Cavanha Filho (2006): especificação técnica, que consiste na definição de materiais, equipamentos e serviços, além de estudos da capacidade do mercado fornecedor e a redução da quantidade de faixas de especificação; padronização de procedimentos, através da qual cada situação na empresa possui um padrão ou recomendação de procedimento; padronização documental, onde todas as questões que envolvem a produção e o recebimento de documentos na empresa podem estar divididos por padrões mínimos, que irão facilitar a recuperação, a velocidade de interpretação, a redução de erros e os controles.

Gaither e Frazier (2006), apontam que os padrões de trabalho auxiliam no planejamento e no controle das operações. Podem ser usados para determinar se a mão de obra de um departamento de produção está apresentando um desempenho acima, abaixo ou dentro dos padrões esperados, por exemplo. Além disso, os autores, apresentam também o padrão de mão de obra, que pode ser definido como o número de minutos por trabalhador necessário para concluir elementos, operações ou produto sob condições operacionais comuns.

Dentre os diversos benefícios da padronização de processos, os principais são: gerar um repositório de diretrizes e padrões; permitir treinar novos funcionários; melhorar o trabalho em equipes; reduzir erros; aumentar a confiança e a eficiência; reduzir reinvenções; reduzir decisões sem regras; reduzir tempos de projeto, desenvolvimento e implementação (CAVANHA FILHO, 2006).

Para que seja possível definir os padrões de processo é preciso assegurar que eles sejam utilizados, por isso, entende-se que devem estar presentes os seguintes requisitos: patrocínio da alta administração; simplicidade; participação ampla da confecção; comunicação fácil e intuitiva; consequências para usos fora do padrão, quando não haja justificativas; pouco texto, direto ao ponto; premiações, incentivos; e, demonstrações de vantagens (CAVANHA FILHO, 2006).

Outro aliado da padronização de processos é o gerenciamento da rotina. Segundo Campos (2004), o gerenciamento da rotina do trabalho é baseado em: perfeita definição da autoridade e da responsabilidade de cada pessoa; na padronização de processos e do trabalho; no monitoramento dos resultados destes processos e a comparação com as metas; num bom ambiente de trabalho e na máxima utilização do potencial mental das pessoas; e, na melhoria contínua, busca da perfeição. 


\section{I PROCEDIMENTOS METODOLÓGICOS}

Esta pesquisa refere-se a um estudo de caso, com abordagem qualitativa, realizado a partir de um enfoque descritivo, visto que pesquisa tem como objetivo compreender a realidade, em profundidade, do processo produtivo da empresa.

Para a coleta de dados, foram utilizadas informações provenientes de fontes primárias, coletadas a partir de entrevistas não estruturadas com os gestores envolvidos no processo, questionários aplicados para todos os 50 funcionários da empresa, pesquisa documental realizada em relatórios de produção e pedidos de vendas da empresa, além da observação.

As entrevistas foram feitas no decorrer do estudo com 4 gestores, visando identificar pontos críticos que interferem do processo. Os questionários objetivaram identificar pontos críticos observados a partir dos funcionários que executam as atividades, bem como identificar oportunidades de melhoria. Os dados coletados foram analisados com base na análise de conteúdo.

\section{I DIAGNÓSTICO DO SETOR/ÁREA DE ESTÁGIO}

A lg Soft Free Form possui três linhas diferentes, Basic, Plus e Premium. Além das diferenças no material, como o índice de refração, alturas, diâmetros, entre outros, a maior diferença está no campo de progressão visual, que aumenta conforme a linha. Apesar dessas diferenças, o processo produtivo das lentes é basicamente o mesmo, conforme Figura 1.

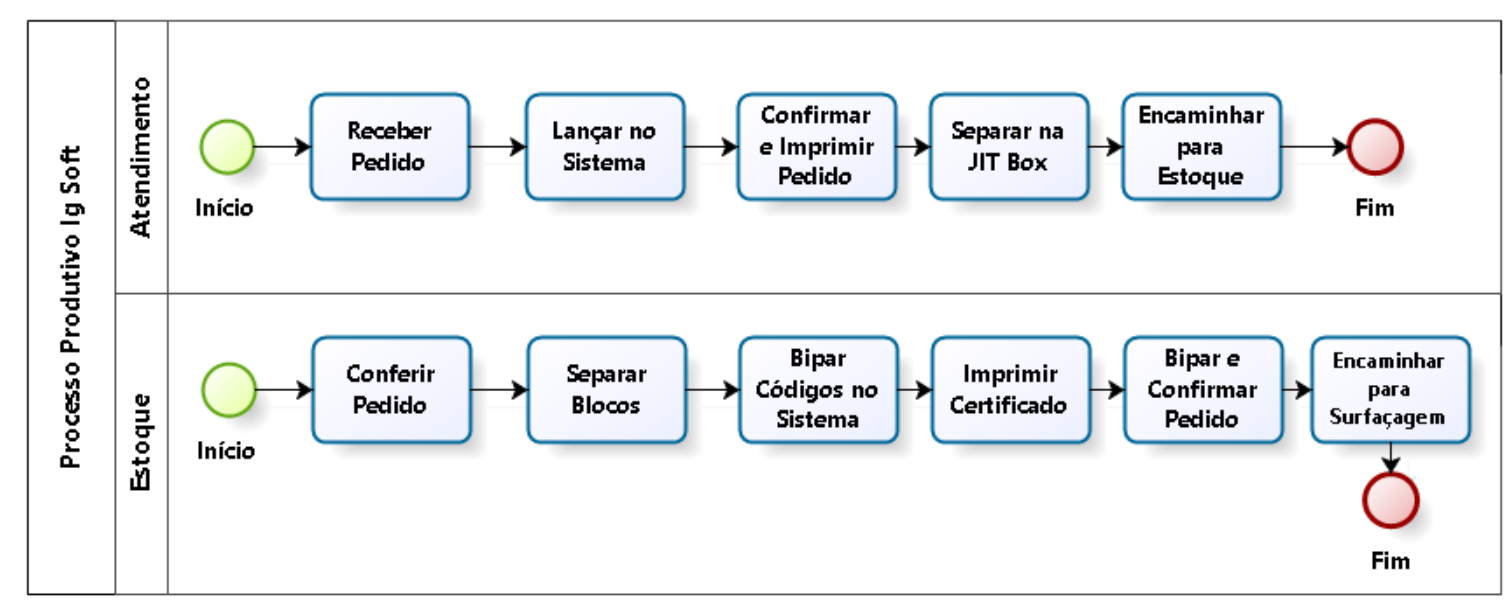

Figura 1 - Fluxograma 1: Atendimento e Estoque Fonte: Elaborado pela autora.

No setor de atendimento identificou-se perda por espera, pois, o atendente acumula os pedidos para depois encaminhá-los para o estoque. Além disso, o erro de digitação de dados no sistema também pode gerar problemas, por isso, é necessário a atenção do atendente na conferência dos dados, para não gerar retrabalhos. 
Dando sequência no processo, passa-se para o setor de estoque, onde identificouse o problema de mistura esporádica dos blocos no estoque, que mesmo sendo de maneira esporádica, aumenta o tempo da atividade, pois, o funcionário perde tempo procurando os blocos que estão misturados. Identicou-se ainda a falta de inspeção dos blocos antes de encaminhar para a surfaçagem, pois, o funcionário não inspeciona minuciosamente os blocos, e assim passam alguns com defeitos, não sendo possível devolvê-los ao fabricante pois já foram sufaçados. Além disso, também ocorre a perda por espera, pois, os pedidos ficam acumulados até que um operador encaminhe-os para surfaçagem. Apresenta-se, na Figura 2, o fluxograma da surfaçagem digital.

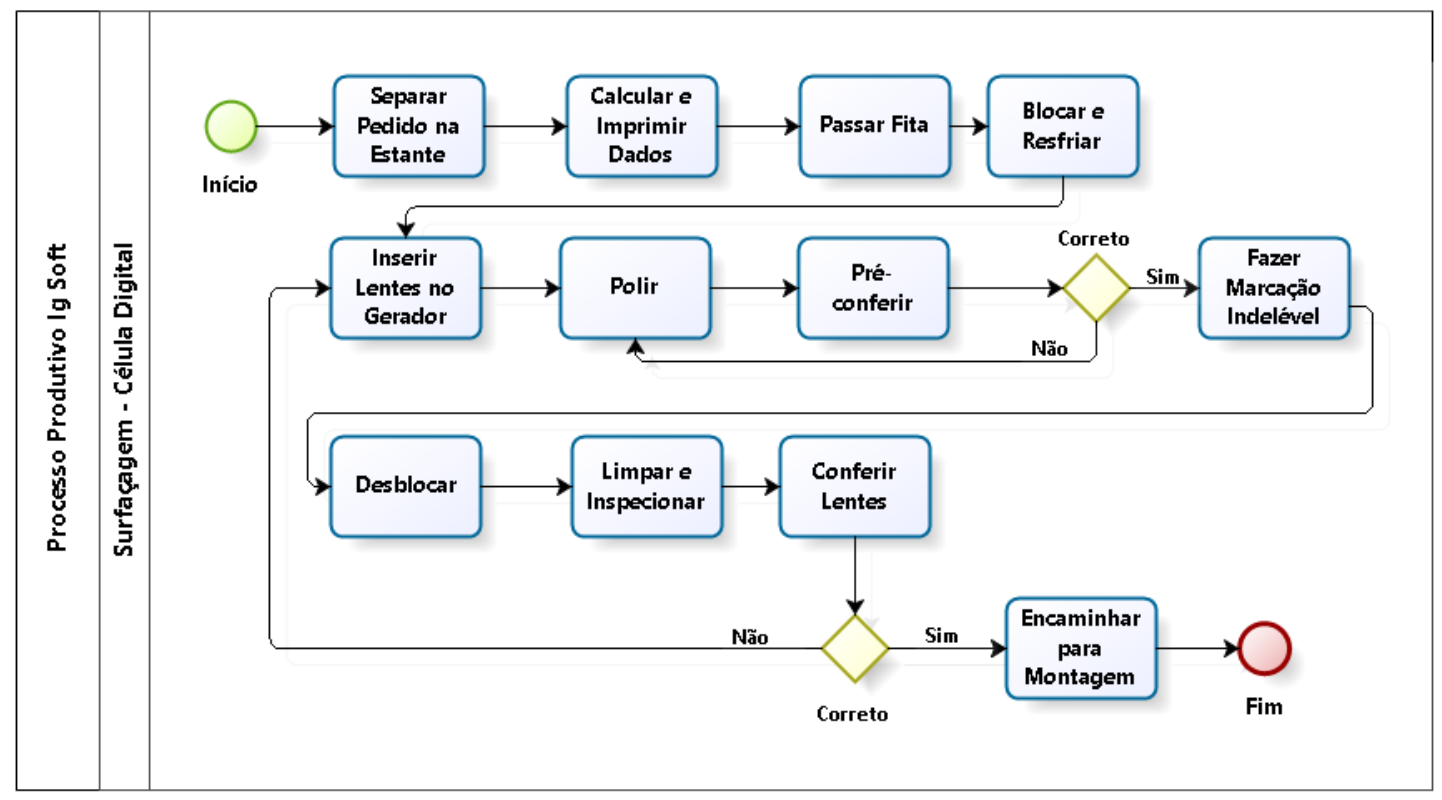

Figura 2 - Fluxograma 2: Surfaçagem digital Fonte: Elaborado pela autora.

O resfriamento é o gargalo do setor de surfaçagem, onde os pedidos aguardam mais tempo para seguirem o processo. Na pré-conferência identificou-se perda por produto defeituoso, pois a marcação indelével ficou muito forte, ocasionada por erro da máquina, não sendo possível reparar o erro. Na Figura 3 apresenta-se o fluxograma da montagem e expedição. 


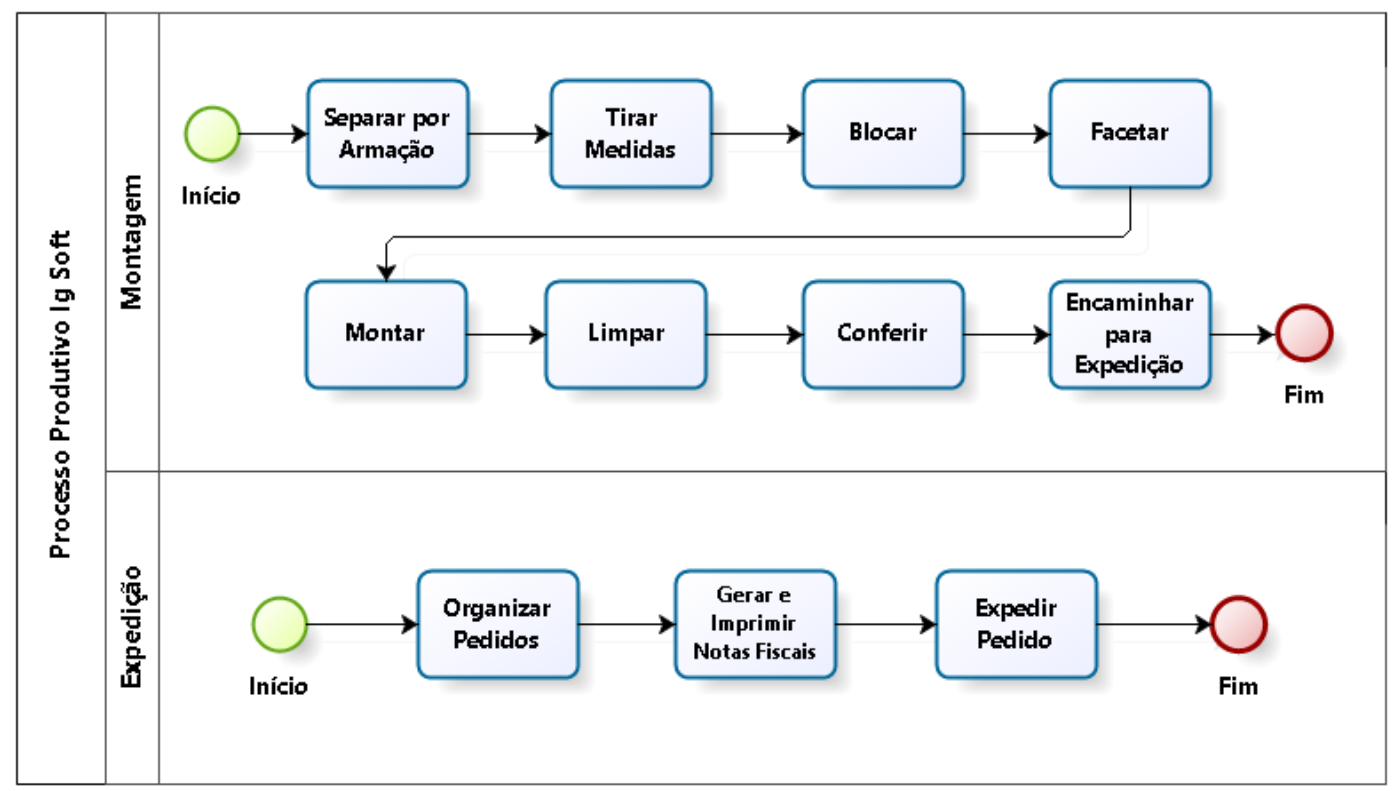

Figura 3 - Fluxograma 3: Montagem e Expedição

Fonte: Elaborado pela autora.

Na etapa da montagem é que ocorre a maioria das quebras por manuseio, gerando perdas e retrabalhos. Na expedição, além das perdas por espera, identificou-se também a perda por transporte que acontece em todas as atividades de encaminhamento para o processo seguinte.

Para melhor visualização das perdas que ocorrem no processo de surfaçagem digital e montagem, realizou-se o detalhamento com informações obtidas através de um relatório de requisições do estoque da empresa. Percebe-se também que as perdas com maior valor foram ocasionadas por "dioptria errada" com 15,26\% e "colada errada" com 14,94\%. Porém, neste relatório não constam as perdas das células de surfaçagem tradicional, além disso, o valor estimado das perdas é apenas do valor dos blocos, não leva em consideração perda do valor de mão-de-obra, insumos, tempo, entre outros.

Com base no diagnóstico, os processos foram analisados e proposições de melhoria foram elencadas. Inicialmente realizou-se a identificação e medição das perdas do processo produtivo das lentes $\lg$ Soft ${ }^{\circledR}$.

\begin{tabular}{|c|c|l|}
\hline Setor & Perda & \multicolumn{1}{c|}{ Descrição } \\
\hline $\begin{array}{c}\text { Atendi- } \\
\text {-mento }\end{array}$ & Espera & $\begin{array}{l}\text { Acontece devido ao acúmulo de pedidos antes do encaminha- } \\
\text { mento para o setor de estoque. }\end{array}$ \\
\cline { 2 - 3 } & $\begin{array}{c}\text { Produto defei- } \\
\text { tuoso }\end{array}$ & $\begin{array}{l}\text { Erro de digitação: se dá pela falta de atenção dos atendentes no } \\
\text { momento de lançar o pedido no sistema, ou quando o cliente pas- } \\
\text { sa dados incorretos. }\end{array}$ \\
\hline
\end{tabular}




\begin{tabular}{|c|c|c|}
\hline \multirow[t]{2}{*}{ Estoque } & $\begin{array}{l}\text { Produto defei- } \\
\text { tuoso }\end{array}$ & $\begin{array}{l}\text { Base errada: acontece quando não é conferida } \\
\text { a base solicitada, que algumas vezes não está } \\
\text { de acordo com os demais dados do pedido, pre- } \\
\text { cisando assim, descartar o bloco. Mistura dos } \\
\text { blocos: ocasionada quando algum funcionário } \\
\text { não guarda os blocos nos seus devidos lugares, } \\
\text { fazendo com que haja perda de tempo e confusão } \\
\text { no momento de separar os blocos para os próxi- } \\
\text { mos pedidos. Falta de inspeção dos blocos: se } \\
\text { dá antes do encaminhamento para a surfaçagem, } \\
\text { quando o funcionário não inspeciona minuciosa- } \\
\text { mente os blocos, e defeitos passam despercebi- } \\
\text { dos, comprometendo a qualidade das lentes }\end{array}$ \\
\hline & Espera & $\begin{array}{l}\text { - Acontece devido ao acúmulo dos pedidos até que } \\
\text { um operador encaminhe-os para o próximo setor. }\end{array}$ \\
\hline \multirow[t]{2}{*}{$\begin{array}{l}\text { Surfaça- } \\
\text {-gem }\end{array}$} & Espera & $\begin{array}{l}\text { No início do processo: quando os pedidos são separados na es- } \\
\text { tante e aguardam a próxima atividade. No encaminhamento: onde } \\
\text { o operador deixa os pedidos acumularem para então levá-los até } \\
\text { o setor de montagem. }\end{array}$ \\
\hline & $\begin{array}{l}\text { Produto defei- } \\
\text { tuoso }\end{array}$ & $\begin{array}{l}\text { Erros de cálculo: podem ser ocasionados por falta } \\
\text { de atenção do operador ao desenvolver o cálculo } \\
\text { ou erro no sistema. Blocagem errada: acontece } \\
\text { devido falhas do operador. Problema no gerador: } \\
\text { acontece quando o gerador deixa marcas irrepa- } \\
\text { ráveis nas lentes, além de não fazer as curvaturas } \\
\text { adequadas gerando erro de dioptria. Marcação } \\
\text { incorreta: acontece quando a marcação indelével } \\
\text { ficou muito forte, ocasionada por erro da máqui- } \\
\text { na, não sendo possível reparar o erro. Quebras } \\
\text { de lentes: se dá devido a espessura da lente ou o } \\
\text { erro no manuseio por parte do operador. }\end{array}$ \\
\hline \multirow[t]{2}{*}{$\begin{array}{l}\text { Monta- } \\
\text {-gem }\end{array}$} & $\begin{array}{l}\text { Produto defei- } \\
\text { tuoso }\end{array}$ & $\begin{array}{l}\text { Blocar e facetar: ocasionadas pela colagem e corte errados nes- } \\
\text { sas duas atividades. Quebras e riscos por manuseio: acontece } \\
\text { quando o funcionário manuseia as lentes incorretamente. Troca } \\
\text { de OS: quando por falta de atenção, inverte-se as lentes do olho } \\
\text { direito e esquerdo. }\end{array}$ \\
\hline & Espera & $\begin{array}{l}\text { Ocorre quando os pedidos aguardam até que os atendentes os } \\
\text { levem para a expedição. }\end{array}$ \\
\hline
\end{tabular}

Tabela 1: Descrição das perdas

Fonte: Elaborado pela autora

Após a identificação, as perdas foram mensuradas. Os dados foram obtidos através dos relatórios de requisições do estoque da empresa. Deve-se destacar que as perdas foram classificadas pela frequência em que ocorrem, e não pelo custo que representam para a empresa, pois existe uma diversidade de produtos com diferentes valores, e isso faz com que o motivo da perda torne-se mais relevante, pois pode acontecer com modelo qualquer lente.

No processo de Surfaçagem Digital pode-se perceber que as ocorrências "Cálculo errado", "Dioptria errada", "Defeito no bloco", "Corte errado", "Lente com risco" e "Base errada", representam $68,17 \%$ do total de 842 perdas, mais da metade das ocorrências estão concentradas em 6 de 28 indicadores.

Da mesma maneira, foram classificadas as perdas por produto defeituoso, ocorridas na Montagem, no período analisado. Percebe-se que uma grande quantidade 
de perdas ocorre, também com mais frequência em 6 indicadores, que são: "Quebra no manuseio", "Corte errado", "Eixo fora", "Colada errado", "Lente com risco" e "Defeito na Lente".

Para medir as perdas por espera, analisou-se o tempo de produção de 5 pedidos de lentes Ig Soft, com materiais e situações diferentes. Pode observar-se que o tempo de produção não é padronizado. Isso pode ser atribuído devido aos fatores que influenciam a produção: tipo de produto, tratamentos inclusos, urgência do pedido, quebras e defeitos que ocorrem durante a produção, entre outros.

Através da análise do processo produtivo da Iguaçu Distribuidora de Produtos Óticos foram identificados alguns pontos que precisam ser levados em consideração na definição de um padrão de produção:

- A Iguaçu possui uma demanda específica, que requer lentes produzidas conforme suas necessidades, por essa razão, a empresa precisa submeter-se a produção por encomenda;

- Durante o processo produtivo ocorrem situações onde se faz necessário a inclusão de pedidos urgentes. Tais pedidos são inseridos no processo produtivo e são fabricados antes dos pedidos que já estavam na fila de espera;

- Na matriz o processo produtivo inclui surfaçagem e montagem, já nas filais é realizada apenas o processo de montagem, pois, a lentes surfaçadas são enviadas pela matriz. Os produtos são encaminhados para as filiais através de malotes, todos os dias, às 17 horas. Por isso, muitas vezes precisam ser produzidos antes dos demais pedidos;

- Devido às necessidades dos clientes e especificações de cada produto, as lentes podem seguir diferentes destinos dentro do processo produtivo, como por exemplo: as lentes podem ser apenas surfaçadas; apenas montadas; podem receber tratamento anti-reflexo, ou não; podem receber coloração, ou não; entre outras possibilidades.

- Após descrição e análise dos processos, foram propostas melhorias para o processo produtivo.

- Aumento de Treinamentos: Essa proposta envolve a realização de mais treinamentos para os funcionários, tanto os atuais como para os de futuras contratações. Poderiam ser feitas aulas práticas nos setores e realização de mais palestras, por exemplo. Proporcionar aos funcionários o conhecimento do processo produtivo como um todo, para que todos saibam o que acontece em cada processo desde a entrada na empresa até a expedição final. Esses treinamentos causariam impacto direto nas perdas por produtos defeituosos, pois, os funcionários teriam mais habilidade para exercer suas funções. Além disso, proporcionaria o aumento da comunicação interna e entendimento de todos os setores, que é um dos pontos a melhorar, citados pelos funcionários.

- Incentivar o uso da web para fazer pedidos: Essa medida envolve a interação e comunicação com os clientes, as ópticas. Incentivar por meio de promoções, benefícios, descontos, entre outros, a utilização do sistema Web que a Iguaçu disponibiliza aos 
seus clientes, através do site, http://187.45.121.170/webpedidos/login.php. Explicar a importância da utilização desta ferramenta, como mais agilidade, pois o pedido entra no sistema da Iguaçu muito antes dos pedidos feitos por blocos; segurança dos dados; entre outros.

- RNC - Registro de Não Conformidades para o setor de Atendimento e Comercial: Registrar em forma de tabela, todas as reclamações e sugestões feitas pelos clientes. O registro desses acontecimentos, auxiliará na análise de pontos como: reclamações mais frequentes; clientes que mais recebem produtos defeituosos; onde a empresa está deixando a desejar. O não registro dessas informações faz com que os problemas sejam resolvidos de maneira isolada e esquecidos, sem que possam ser analisados.

- Implantação de um setor de Controle de Qualidade: A Iguaçu Distribuidora de Produtos Óticos é uma empresa consolidada no mercado, e que abrange diversas regiões do sul do país, por essa razão, em virtude da abrangência da empresa e da quantidade de produtos produzidos, é de extrema importância implantação deste setor. O mesmo iria executar o controle de qualidade tanto dos blocos brutos, quanto do produto acabado. Esta medida diminuiria as perdas por produto defeituoso, como "defeito no bloco", por exemplo, que está elencado como a $3^{\circ}$ perda que mais ocorre na Surfaçagem Digital. Além disso, diminuiria os custos com retrabalhos e situações desagradáveis com envios de produtos defeituosos aos clientes.

- Possibilidade de adequar o layout ou mudar de local: Essa proposta esta definida como longo prazo, devido ao alto custo e trabalho envolvido na realização da mesma. Porém, melhoraria as questões de deslocamento no processo produtivo e as perdas por transporte. A readequação do layout proporcionaria o transporte dos pedidos de maneira mais fluida e evitaria o deslocamento desnecessário que pode causar quebras e perdas de produtos. Além disso, a distância entre os setores faz com que os pedidos se acumulem para evitar o transporte, mas em contrapartida provoca a perda por espera, pelo acúmulo de pedidos.

- Novo plano de horários para entrega de pedidos e produção: Essa proposta encontra-se como longo prazo, pois, é uma questão que já vem sendo discutida entre os funcionários e direção, durante algum tempo, porém, prolonga-se a possibilidade de implantação devido à sua complexidade de execução e envolvimento de todo o ramo óptico. A empresa já utiliza uma tabela com os prazos mínimos para determinadas situações, como tratamento anti-reflexo, encomenda de blocos, entrega para filiais, etc. Porém, o principal problema são os pedidos que entram no processo produtivo fora da ordem cronológica. Esses pedidos passam na frente de outros que já estavam na fila de espera e acabam aumentando ainda mais as filas, o tempo de produção e, consequentemente, as perdas por espera. Muitas seriam as melhorias obtidas através desse plano, como: possibilidade de padronizar a produção; diminuição do tumulto e das filas de espera de produtos entre os setores; possibilidade de realizar as atividades com mais calma e atenção, diminuindo assim os erros e retrabalhos, etc. 


\section{I CONSIDERAÇÕES FINAIS}

A competitividade do mercado atual, a necessidade de gerar vantagens competitivas e a inovação de um processo produtivo, influenciaram a decisão de abordar, como tema deste trabalho a gestão de processos. Assim, a parir do objetivo geral de propor melhorias no processo produtivo da linha de lentes Ig Soft $\circledast$ na empresa Iguaçu Distribuidora de Produtos Óticos, desenvolveu-se um série de objetivos específicos que embasaram este estudo.

A realização do diagnóstico da situação atual do processo produtivo da linha lg Soft ${ }^{\circ}$, foi estruturado de maneira detalhada, abordando todos os setores do processo de produção digital e as atividades nele realizadas. Esse diagnóstico proporcionou a execução dos demais objetivos específicos, mas, principalmente o de identificar os pontos críticos e as perdas do processo produtivo, analisando e medindo os mesmos.

A proposta de melhorias foi desenvolvida pensando nas necessidades da Iguaçu e como essas melhorias poderiam contribuir para diminuição de inconformidades e desperdícios no processo produtivo da linha $\lg$ Soft®.

As propostas de curto prazo, foram: o aumento de treinamentos; o incentivo ao uso da web para fazer pedidos, e; a elaboração dos Registros de Não Conformidades para o setor de atendimento e comercial. A proposta de médio prazo, foi: a implantação de um setor de Controle de Qualidade. Já, as propostas de longo prazo, de cunho mais complexo e envolvimento de fatores externos, foram: a possibilidade de adequar o layout ou mudar de local, e; a criação de um novo plano de horários para entrega de pedidos e produção.

A partir deste estudo pode-se perceber a importância da gestão de processos no âmbito empresarial e de produção. Que através de medidas simples pode-se encontrar meios de melhorar muitas situações. Todavia, medidas simples também podem envolver uma infinidade de fatores que influenciam a tomada de decisões, onde o fator decisivo é a iniciativa de realizar e colocar as medidas em prática.

\section{REFERÊNCIAS}

ABIÓPTICA; GS\&MD. Estudo de óticas 2014. Disponível em: <http://www.abioptica.com.br/ws2011/ webapps/imagefile/arquivos/sum\%C3\%A1rio_executivo\%20_estudo_\%C3\%B3ticas_2014.pdf>. Acesso em: 18 abr. 2016.

ANTUNES, Junico (Org.). Sistemas de produção: conceitos e práticas para projeto e gestão da produção enxuta. Porto Alegre: Bookman, 2008.

BALLESTERO-ALVAREZ, María Esmeralda. Gestão de qualidade, produção e operações. 2. ed. São Paulo: Atlas, 2012.

BARROS, Elsimar; BONAFINI, Fernanda Cesar (Orgs.). Ferramentas da qualidade. São Paulo: Pearson Education do Brasil, 2014

BEUREN, Ilse Maria. Como elaborar trabalhos monográficos em contabilidade - teoria e prática. 3 ed. São Paulo: Atlas, 2013. 
CAMPOS, Vicente Falconi. Gerenciamento da rotina do trabalho do dia-a-dia. 8. ed. Belo Horizonte: INDG, 2004.

CAMPOS, Vicente Falconi. Qualidade total: padronização de empresas. Belo Horizonte: Fundação Christiano Ottoni, 1992.

CARVALHO, Marly Monteiro de; PALADINI, Edson Pacheco (Coords.). Gestão da qualidade: teoria e casos. Rio de Janeiro: Campus, 2005.

CAVANHA FILHO, Armando Oscar. Estratégias de compra. Rio de Janeiro: Ciência Moderna, 2006.

CONTADOR, José Celso (Coord.). Gestão de operações: a engenharia de produção a serviço da modernização da empresa. 2. ed. São Paulo: E. Blucher, 1998.

CORRÊA, Henrique Luiz; CORRÊA, Carlos A. Administração de produção e operações: manufatura e serviços: uma abordagem estratégica. 3. ed. São Paulo: Atlas, 2012. 680 p. ISBN 9788522469185 (enc.)

CORREAA; Vitor Grünpeter. Proposta de melhoria dos processos de produção em um laboratório de lentes. São Paulo, 2008. Disponível em: <http://pro.poli.usp.br/wp-content/uploads/2012/pubs/ proposta-de-melhoria-dos-processos-de-producao-em-um-laboratorio-de-lentes.pdf> Acesso em: 30 de ago. 2016.

FLICK, Uwe. Introdução à pesquisa qualitativa. 3 ed. São Paulo, Artmed, 2009.

GAITHER, Norman; FRAZIER, Greg. Administração da produção e operações. 8. ed. São Paulo: Thomson, 2002-2004.

GIL, Antonio Carlos. Como elaborar projetos de pesquisa. 5 ed. São Paulo: Atlas, 2016.

KRAJEWSKI, Lee J; RITZMAN, Larry P; MALHOTRA, Manoj K. Administração de produção e operações. 8. ed. São Paulo: Pearson Education do Brasil, c2009.

LEITE, Anderson Ramom do Amaral; DIAS, Jéssica Cleide Oliveira. Planejamento e controle do lead time para redução do prazo de entrega em uma organização do setor óptico. ENCONTRO NACIONAL DE ENGENHARIA DE PRODUCAO, Perspectivas Globais para a Engenharia de Produção. Fortaleza, CE, Brasil, 13 a 16 de outubro de 2015. Disponível em: <http://www.abepro.org. br/biblioteca/TN_STO_212_256_27314.pdf . Acesso em: 30 de ago. 2016.

MACHADO, Claralucia Prates; TONDOLO, Vilmar Antonio Gonçalves. Perda por ruptura em gôndola: uma análise do Sistema Toyota de Produção, na indústria alimentícia e no varejo supermercadista.

Gepros: Gestão da Produção, Operações e Sistemas, v. 9, n. 3, p. 15, 2014.

MACHADO, Magda Bitencourt. Processo de industrialização de lentes estudo de caso: empresa Tremarin Laboratório Óptico. Alvorada, 2011. Disponível em: <http://acad.saomarcos.br/rsm/ bitstream/123456789/28/1/magda-bitencourt-machado.pd\$ Acesso em: 29 de ago. 2016.

MARTINS, Petrônio G.; LAUGENI, Fernando P. Administração da produção. 2. ed. rev., aum. e atual. São Paulo: Saraiva, 2005.

MARTINS, Tomas Sparano; GUINDANI, Roberto Ari. Estratégia e competitividade. Curitiba: Intersaberes, 2013.

MOREIRA, Daniel Augusto. Administração da produção e operações. 5. ed. São Paulo: Pioneira Thomson Learning, 2000. 
PAIM, Rafael et al. Gestão de processos: pensar, agir e aprender. Bookman Editora, 2009.

PAIXÃO, Marcia Valéria. Inovação em produtos e serviços. Curitiba: Intersaberes, 2014.

RAMPAZZO, Lino. Metodologia científica. 3 ed. Edições Loyola, São Paulo-SP, 2002.

RICHARDSON, Roberto Jarry. Pesquisa social: métodos e técnicas. 4 ed. São Paulo: Atlas, 2017.

ROCHA, Duílio. Fundamentos técnicos da produção. São Paulo: Makron Books do Brasil, 1996.

SEVERINO, Antônio Joaquim. Metodologia do trabalho científico. 23 ed. São Paulo: Cortez, 2007.

SHINGO, Shigeo. O sistema Toyota de produção: do ponto de vista da engenharia de produção. 2. ed. Porto Alegre: Bookman, 1996.

WILDAUER, Egon Walter; WILDAUER, Laila Del Bem Seleme. Mapeamento de processos: conceitos, técnicas e ferramentas. Curitiba: Intersaberes, 2015.

YIN, Robert K. Pesquisa qualitativa do início ao fim. Porto Alegre: Penso, 2016. 


\section{CAPÍTULO 3}

\section{INTELIGÊNCIA EM REDE: A MELHORIA DO PROCESSO DECISÓRIO A PARTIR DA ATUAÇÃO

Data de aceite: 11/03/2020

Data de submissão: 26.12.2019

Ricardo de Assis Teixeira Servidor Público em exercício na Casa Civil da Presidência da República Brasília - DF

Lattes: http://lattes.cnpq.br/5085335012577582

Danitza Passamai Rojas Buvinich Servidora Pública da Agência Nacional de Vigilância Sanitária - ANVISA

Brasília - DF

Lattes: http://lattes.cnpq.br/4295486712634766

RESUMO: O artigo apresenta os conceitos e discute a importância de uma gestão sistematizada de dados, informações e conhecimento no contexto público para gerar inteligência no governo. Apresenta e discute os conceitos de organizações como sistemas abertos. Destaca o potencial da atuação em rede otimizar os esforços de geração de inteligência organizacional. Apresenta dois estudos de casos que exemplificam como a atuação em rede pode melhorar o processo de tomada de decisão. Conclui que dados, informação e conhecimento são insumos indissociáveis e complementares no ambiente organizacional; que é fundamental a existência de estratégias para gestão integrada desses ativos no intuito de proporcionar inteligência no governo; que é essencial a criação de uma ambiente legal mais adequado no governo para a atuação em rede; e que para fortalecimento das ações de inteligência organizacional é essencial a criação de capacidade organizacional para gerir recursos informacionais.

PALAVRAS-CHAVE: inteligência, decisão, gestão da informação, gestão do conhecimento

NETWORK INTELLIGENCE: THE IMPROVEMENT OF THE DECISION-MAKING PROCESS FROM THE NETWORKACTIVITIES

ABSTRACT: The article presents the concepts and discusses the importance of a systematized data, information and knowledge management in the government context. It presents organizations as an open systems, and highlights the potential of institutional association to optimize the efforts of generating organizational intelligence. To concretize the abstract conceptual discussion, two case studies are presented. As conclusion, the article shows that data, information and knowledge are indissociable and complementary inputs in the organizational environment; that integrated management strategies are essential in order to strength organizational intelligence to provide better data use, and evidence based public 
policies; finally the creation of an appropriated legal environment for institutional association is essential to build organizational capacities.

KEYWORDS: intelligence, decision making, information management, knowledge management

\section{I INTRODUÇÃO}

Vivemos em um mundo complexo, globalizado e em constante mutação, o que se reflete no mundo corporativo moderno, marcado por processos de trabalhos mundialmente conectados, impactado pela economia digital, pela alta competividade e pela diversificação de produtos e serviços, cada vez mais personalizados para atender as necessidades dos clientes.

Esse contexto requer estratégias para lidar com a complexidade do ambiente interno e externo da organização. Nesse sentido, identificar tendências, compreender as necessidades dos clientes, identificar oportunidades e ameaças, montar uma rede de parceiros, criar capacidade adaptativa da organização, dentre outras atividades se torna essencial para a sobrevivência e competividade das instituições modernas.

No governo não é diferente, a escassez de recursos públicos, o avanço tecnológico e todas as transformações comportamentais ocorridas na sociedade requerem que sejam ofertados produtos e serviços pelo governo cada vez mais customizados, transparentes, seguros e com qualidade.

Para transpor todas as dificuldades do ambiente corporativo moderno, o uso sistemático e estratégico de dados, informação e conhecimento se tornam essenciais, pois tais insumos serão capazes de interpretar situações, traduzir preferências, gerar inovação, promover transparência, reduzir custos e gerar inteligência, ou seja, gerar desenvolvimento organizacional.

É certo que o ambiente corporativo moderno apresenta diversos desafios para as instituições contemporâneas, contudo, em seu bojo, também se destacam diversas oportunidades que podem ser aproveitadas para a melhoria do desempenho organizacional. Nesse sentido, registra-se a possibilidade das instituições se associarem para conjugar competências, formando uma rede de apoio para fortalecimento da governança.

Adotar uma estratégia de atuação em rede para proporcionar uma adequada disponibilidade de dados, informações e conhecimentos para subsidiar a tomada de decisão pode resultar em uma melhora significativa do processo decisório, pois, desse modo, os esforços de captação, seleção e interpretação de sinais do ambiente podem ser descentralizados e fortalecidos, por meio da conjugação de competências interinstitucionais.

Atuar em rede para aumentar a disponibilidade de dados, informações e conhecimentos estratégicos, no intuito de fortalecer o processo de inteligência organizacional, não é sinônimo de uma maior quantidade de conhecimento (tácito e 
explícito), mas sim da combinação inteligente desses ativos para melhorar a tomada de decisão, conforme aponta a obra de Belluzzo \& Feres (2003).

Uma organização do conhecimento representa tanto o conhecimento explícito quanto o tácito, proporcionando vantagens competitivas nas organizações, e não está relacionado com quantidade de informação obtida/estocada, e sim em fazer uso inteligente da mesma.

A atuação em rede também representa uma estratégia de atuação da organização como sistema aberto, a partir do momento em que a instituição se abre para a formação de vínculos com os demais membros do seu ecossistema para a troca de insumos, permitindo uma maior integração e conformidade com o seu ambiente, propiciando um cenário favorável para a prosperidade e sobrevivência.

Ao longo do texto, será abordado como a atuação organizacional em rede e como sistema aberto, consorciado com uma boa capacidade de gerir recursos informacionais da organização pode melhorar a aptidão corporativa de reunir conhecimento para resolver problemas, fortalecendo, assim, o processo de inteligência organizacional.

\section{I FUNDAMENTAÇÃO TEÓRICA}

\subsection{Gestão da Informação e Conhecimento}

Por tratar-se de insumos nem sempre concretos e por ser, ainda, incipiente em muitas organizações processos com propósitos definidos para gestão de dados, informações e conhecimentos, é comum no governo certa desconfiança a respeito das iniciativas que envolvem esse tema.

Parte dessa desconfiança também deriva da heterogeneidade de experiências a respeito da gestão desses insumos, o que ocasiona na ausência de limites, propósitos e eixos de atuação reconhecidos para uma implementação efetiva de uma gestão de evidências no governo.

Nesse sentido, é essencial que seja compreendido a origem e as definições sobre o processo de gestão desses insumos, no intuito de não se perder o referencial teórico durante o processo de reflexão sobre como a gestão desses ativos pode influenciar na implementação de uma política de inteligência organizacional.

O termo gestão da informação tem sua origem relacionada com os processos de gestão de documentos, biblioteconomia especializada e da ciência da informação. Os primeiros registros a respeito da moderna gestão da informação datam de 1934, nos trabalhos de Paul Otlet, no livro Traité de documentation. Portanto, o termo gestão da informação foi cunhado muito antes da era dos computadores.

Gestão da informação define-se como a aplicação de princípios administrativos à aquisição, organização, controle, disseminação e uso da informação para a operacionalização efetiva de organizações de todos os tipos (WILSON, 1997). De modo semelhante, Ponjuan Dante(1998) define o ciclo da informação no ambiente organizacional. 


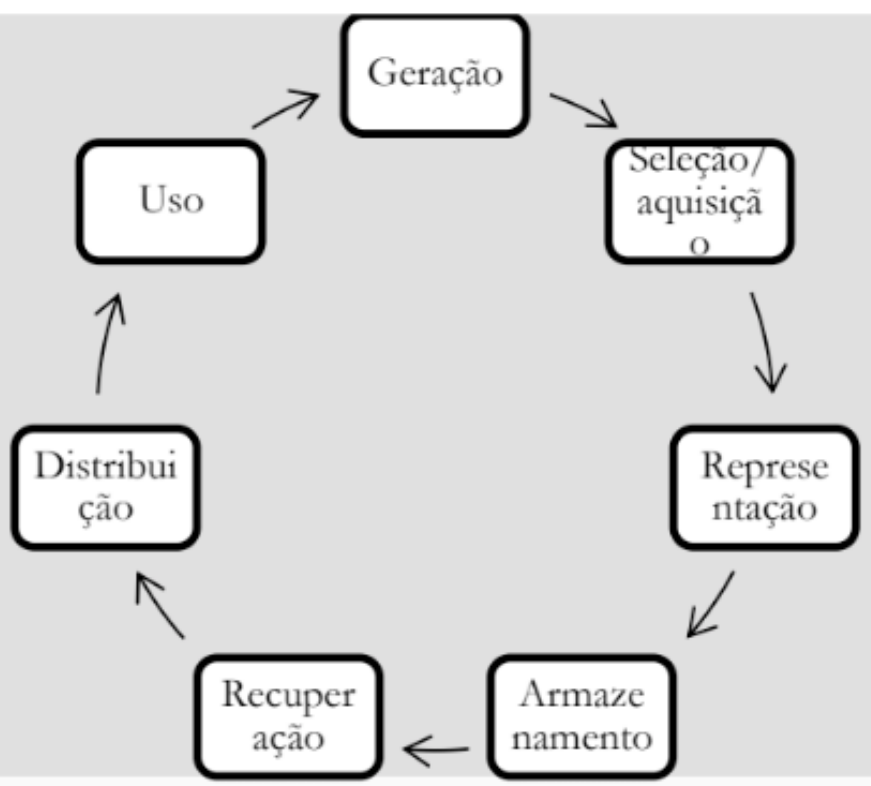

Figura 2 - Ciclo Informacional FONTE: Ponjuan Dante (1998, p.47).

O ciclo informacional é iniciado quando se detecta uma necessidade informacional, um problema a ser resolvido, uma área ou assunto a ser analisado. É um processo que se inicia com a busca da solução a um problema, da necessidade de obter informações sobre algo, e passa pela identificação de quem gera o tipo de informação necessária, as fontes e o acesso, a seleção e aquisição, registro, representação, recuperação, análise e disseminação da informação, que, quando usada, aumenta o conhecimento individual e coletivo (TARAPANOFF KIRA, 1998).

Ao longo do tempo, a gestão da informação que tinha uma forte identificação com a gestão de documentos ganhou uma concepção mais estratégica, ampliando o seu escopo para ser utilizada como importante insumo para o planejamento estratégico, melhoria do processo decisório, monitoramento do ambiente externo e interno da organização, melhoria e automatização de processos, etc.

Assim, compreende-se o processo de gestão da informação como sendo a execução do fluxo de busca, seleção, representação, armazenamento, recuperação, distribuição e uso da informação, como etapa preliminar e essencial do processo de análise e, consequente, tomada de decisão.

A gestão do conhecimento é uma disciplina mais recente e menos consolidada do que a gestão da informação. A gestão do conhecimento começou a despertar o interesse de pesquisadores e gestores no final da década de 1980, em resposta ao movimento de globalização e ao uso de computadores, iniciativas que proporcionaram a disseminação da informação em patamares não vistos anteriormente.

A abundância de dados e informações geraram uma certa inquietude no mundo corporativo, levando as empresas a se perguntarem quais conhecimentos eram essenciais para o negócio. Prusak registra bem a importância do conhecimento nesse 
contexto:

À medida que o acesso à informação se expande dramaticamente, de forma que as pessoas possam ter acesso a quase toda a informação de que elas necessitam a qualquer hora e em qualquer lugar, o valor das habilidades cognitivas ainda não replicadas pelo silício aumenta (PRU-SAK, 2001, p. 1002).

Com a intensificação do uso da informação para fins estratégicos, percebeu-se que o valor da empresa, na percepção do usuário e do mercado, incorpora aspectos "intangíveis," tais como valor da marca, peso das patentes geradas, capacidade de inovação, talento dos funcionários em especial dos executivos e suas relações com os clientes, software, processos únicos, desenhos organizacionais e outros (LEV, 2004).

Percebeu-se que se esperavam das empresas novas e melhores práticas e soluções, ideias novas, processos de descoberta, novos insights, algo que a informação, por mais bem administrada que seja, não pode fornecer (DAVENPORT; PRUSAK, 1998).

Desta percepção, derivou a expressão "gestão do conhecimento", uma disciplina que trabalha sistematicamente a informação e o conhecimento visando ao aumento da capacidade de resposta da empresa ao meio ambiente com inovação e competência, desenvolvendo a eficácia e o conhecimento corporativo'.

A distinção entre gestão do conhecimento e gestão da informação foi bem definida por OWEN (1999, p.6) da seguinte forma:

A gestão tradicional da informação está focada na informação como objeto
e no gerenciamento da informação explícita e factual por meio de sistemas
automatizados. Seu objetivo é apoiar processos internos e garantir a qualidade
das operações do negócio. A gestão do conhecimento, em sentido mais amplo,
está focada no conhecimento como um conceito e conhecimento tácito "embutido"
nas pessoas e na organização como um todo. Seu objetivo principal é facilitar as
relações de conhecimento fundamental e garantir o desenvolvimento contínuo e a
inovação.

Dando prosseguimento, OWEN (1999, p.6) apresenta uma série de diferenças entre os dois processos de gestão, deixando ainda mais clara à vocação da gestão da informação trabalhar com o conhecimento explícito, enquanto a gestão do conhecimento trabalha com o conhecimento tácito.

1 ROBIN TREHAN. Knowledge Management: a business perspective. 2005. Disponível em: $<w w w . h o s p i t a l i t y n e t . o r g /$ news/4024789.print>. 


\begin{tabular}{|c|c|}
\hline Gestão da Informação & Gestão do Conhecimento \\
\hline$*$ Objeto & $*$ Conceito \\
\hline * Explícito & * Tácito \\
\hline * Informação & * Pessoas \\
\hline * Sistemas & * Organizações \\
\hline * Processos & * Relações \\
\hline * Operações & * Inovação \\
\hline
\end{tabular}

Figura 3 - Comparativa entre GC e Gl

Fonte: OWEN (1999, p.6)

A gestão da informação e conhecimento está inserida no contexto que caracteriza a intitulada sociedade do conhecimento, que recorre predominantemente às novas Tecnologias de Informação e Comunicação para a troca de informações em formato digital. Isso se reflete nas organizações modernas, caracterizadas, sobretudo, pela aceleração dos processos de produção e disseminação da informação e do conhecimento em tempo real.

Tal fato denota a importância de se privilegiar a gestão desses insumos na atualidade, tendo em vista o potencial de essa estratégia melhorar e acelerar processos de trabalho, proporcionar transparência e inteligências em organizações públicas.

\subsection{Organizações em Rede}

A sociedade do conhecimento mudou substancialmente o modo de viver da população mundial, causando alterações nas estruturas de poder das corporações e da sociedade. Atualmente, a hegemonia econômica e social não é mais exercida pelos proprietários dos meios de produção, mas sim por aqueles que detêm o conhecimento, conforme afirma Frederico de Masi (De Masi, 1999).

\footnotetext{
A sociedade industrial produzia, sobretudo, meios de produção, bens a serem consumidos, capital. A sociedade pós-industrial produz, sobretudo, conhecimento, administração de sistemas, capacidade de programar a mudança, ou o futuro. A programação do futuro utiliza-se da "mercadoria" informação.
}

A sociedade da informação ou do conhecimento, aliado com o avanço tecnológico, nos trouxe um novo estilo de vida, marcado pela flexibilidade, instabilidade, imprevisibilidade e conexão em tempo real com pessoas e processos, conforme afirma Lévy (1993, p. 17) "Vivemos um destes raros momentos em que, a partir de uma nova configuração técnica, quer dizer, de uma nova relação com o cosmos, um novo estilo 
de humanidade é inventado".

Todas essas alterações ocorridas na sociedade afetaram diretamente o ambiente do mundo corporativo, trazendo uma nova dinâmica para as instituições públicas e privadas, aumentando a complexidade, a interdependência e a instabilidade no campo de atuação das instituições contemporâneas. Nesse cenário, quatro mudanças de impacto podem ser observadas nas organizações atuais (Tapscoll \& Caston, 1995):

- novas tecnologias (novas metas para a tecnologia de informação, computação em rede, aberta e centrada no usuário);

- novo ambiente empresarial (mercado dinâmico, aberto e competitivo);

- nova empresa (organização aberta com atuação em rede e fundamentada na informação); e

- nova ordem geopolítica (realidade mundial aberta, volátil e multipolar)

Nesse contexto, a organização é vista fazendo parte de um grande ecossistema vivo, onde uma mudança entre uma das partes afeta o funcionamento das demais. Assim, compreender e atuar de modo adequado nesse grande ecossistema de pessoas, organizações e processos se torna fundamental para a sobrevivência e melhoria do desempenho corporativo.

O processo de integração da organização com o ecossistema, formado por diversos sistemas, caracteriza a atuação da instituição como um sistema aberto, maneira pela qual ela fornece e recebe insumos do ambiente para sobreviver e prosperar, conforme Damanpour:

\footnotetext{
Dentro de uma visão integrada, uma organização é vista como um sistema aberto que existe em um ambiente e dele depende para sobreviver e prosperar. Entretanto, o ambiente caracteriza-se pela incerteza, que é determinada por sua complexidade e variabilidade. A complexidade refere-se à magnitude e à variedade dos componentes ambientais. A variabilidade é definida pela frequência e previsibilidade das mudanças nos componentes ambientais. Quanto mais complexo e dinâmico for o ambiente, maior será o nível de incerteza ambiental (Damanpour, 1996).
}

Assim, manter a sobrevivência e proporcionar prosperidade para as organizações nesse ambiente de constante troca de insumos com outros sistemas se tornou uma tarefa complexa, exigindo significativos aperfeiçoamentos nos processos de captação de sinais de mudanças, relacionamento interinstitucional e adaptação interna para o futuro.

Nesse sentido, a atuação em rede surgiu como uma grande oportunidade para otimizar os esforços para manter o equilíbrio dentro desse ecossistema complexo, conjugando competências para explorar o que cada organização melhor realiza, no intuito de diminuir a complexidade dos processos internos e ao mesmo tempo manter 
o acesso a recursos essenciais.

De acordo com Metcalfe (1997), nos arranjos organizacionais em rede predominam as relações de cooperação sobre a competição. Trata-se de organizações independentes que atuam em rede segundo seus valores e diretrizes, em um ambiente democrático e não-hierarquizado. Assim, a atuação em rede é marcada pela horizontalidade, complementaridade e abertas ao pluralismo de ideias e à diversidade cultural (Miguelleto, 2001).

Desse modo, esse modelo de atuação permite uma maior flexibilidade e agilidade na atuação das instituições modernas, harmonizando-se, assim, melhor com a nova configuração social, trazida pela sociedade do conhecimento. Nesse sentido, a cooperação estabelecida entre organizações permite que cada uma se especialize na consecução de seu proposito essencial e conte com a cooperação de outras instituições para executar atividades das quais não possui competência, proporcionando, assim, aumento e melhora da capacidade institucional.

Consequentemente, esse processo exige uma maior qualificação das equipes internas para a coordenação de projetos interinstitucionais, buscando harmonizar a execução de atividades agora descentralizadas com as etapas internas a serem feitas para consecução do objetivo principal da organização. Tal fato denota uma estrutura de trabalho mais horizontal do que vertical, sobrepondo-se ao modelo tradicional de hierarquia apregoado pelo modelo burocrático.

Assim, no âmbito público, abre-se uma nova perspectiva de gestão, que visa reunir recursos estratégicos de modo sinérgico, em busca de benefícios recíprocos entre os parceiros públicos e/ou privados para melhorar e ampliar a capacidade organizacional de decidir e/ou produzir.

\subsection{Inteligência Organizacional}

Alguns autores distinguem os termos inteligência competitiva e inteligência organizacional, empresarial ou corporativa. Assim, parte da literatura vincula o termo inteligência competitiva ao processo de identificação, captura e disseminação de informações relevantes para as empresas oriundas do ambiente externo, enquanto a inteligência organizacional realiza os mesmos processos de tratamento da informação, contudo, tendo como base informações obtidas do ambiente interno.

Portanto, a razão para a distinção entre os termos parece ser a origem dos dados. Por outro lado, alguns autores não fazem essa distinção, abarcando no conceito de inteligência empresarial o tratamento de informações obtidas tanto no ambiente interno quanto no externo. A visão de Jermol, Lavrač e Urbančič (2003) deixa claro esse entendimento:

o conceito inteligência empresarial é relacionado a uma ampla categoria de aplicações e tecnologias empregadas para capturar, armazenar e analisar informação estratégica, além de prover acesso a essa informação aos usuários numa organização, visando a tomada de decisões estratégicas. 
Para o propósito desse trabalho o termo inteligência competitiva e inteligência organizacional (empresarial ou corporativa) serão tratados como sinônimos, pois será dada ênfase à melhoria do processo decisório a partir da utilização sistemática de dados, informações e conhecimentos, não importando a distinção sobre a origem desses insumos.

Conforme já exposto, o ambiente de trabalho das organizações públicas e privadas na atualidade é marcado pela interdependência, complexidade e volatilidade. Para sobreviver e prosperar nesse cenário é necessário que a instituição se integre de modo adequado a esse ambiente, estabelecendo um padrão de troca de insumos de modo eficaz.

Estabelecer um padrão de troca de insumos adequada com o ambiente implica em conseguir compreender os sinais do ambiente interno e externo e, rapidamente, promover adaptações na organização para responder de modo adequado à nova dinâmica exigida, permitindo, assim, a sobrevivência ou importância da instituição no ecossistema.

Essa compreensão do ambiente de trabalho será alcançada por meio do tratamento sistemático de dados, informações e conhecimentos que sejam relevantes para o negócio da organização e possam, assim, gerar produtos de inteligência e, consequente, subsidiar o processo de tomada de decisão. A obra de Canongia define bem o conceito de inteligência competitiva:

\footnotetext{
Objetiva agregar valor à informação, fortalecendo seu caráter estratégico, catalisando, assim, o processo de crescimento organizacional. Nesse sentido, a coleta, tratamento, análise e contextualização de informação permitem a geração de produtos de inteligência, que facilitam e otimizam a tomada de decisão no âmbito tático e estratégico (Canongia, 1998, p.2-3).
}

Assim, surge a necessidade de estruturação de uma solução de inteligência organizacional que permita compreender e monitorar os ambientes interno e externo de uma organização, prospectando, selecionando e disponibilizando dados, informações e conhecimentos essenciais para o processo de tomada de decisão.

Nesse sentido, pode-se definir que o produto do processo de inteligência organizacional é a totalidade da informação estruturada e direcionada para um objetivo, que é gerada quando o sistema de informação de uma organização aumenta a sua capacidade de solução de problemas (Moresi, 2001).

Tendo por base a definição de inteligência organizacional apresentada por Moresi, especialmente quando afirma que a inteligência organizacional é a totalidade da informação estruturada e direcionada para um objetivo, é importante que se tenha em mente a integração e a distinção entre os processos de inteligência organizacional, gestão da informação e gestão do conhecimento. 


\begin{tabular}{|l|l|l|}
\hline \multicolumn{1}{|c|}{ Gestão da Informação } & \multicolumn{1}{|c|}{ Gestão do Conhecimento } & \multicolumn{1}{|c|}{ Inteligência Competitiva } \\
\hline $\begin{array}{l}\text { Foco: Negócio da Organi- } \\
\text { zação }\end{array}$ & $\begin{array}{l}\text { Foco: Capital Intelectual da } \\
\text { Organização }\end{array}$ & $\begin{array}{l}\text { Foco: Estratégias da Organi- } \\
\text { zação }\end{array}$ \\
\hline $\begin{array}{l}\text { Prospecção, seleção e ob- } \\
\text { tenção da informação. }\end{array}$ & $\begin{array}{l}\text { Desenvolvimento da cultura } \\
\text { organizacional voltada ao co- } \\
\text { nhecimento. }\end{array}$ & $\begin{array}{l}\text { Desenvolvimento da capacida- } \\
\text { de criativa do capital intelec- } \\
\text { tual da organização. }\end{array}$ \\
\hline $\begin{array}{l}\text { Mapeamento e reconheci- } \\
\text { mento dos fluxos formais de } \\
\text { informação }\end{array}$ & $\begin{array}{l}\text { Mapeamento e reconhecimen- } \\
\text { to dos fluxos informais de in- } \\
\text { formação. }\end{array}$ & $\begin{array}{l}\text { Prospecção, seleção e filtra- } \\
\text { gem de informaçães estratégi- } \\
\text { cas nos dois fluxos informacio- } \\
\text { nais: formais e informais. }\end{array}$ \\
\hline $\begin{array}{l}\text { Tratamento, análise e ar- } \\
\text { mazenamento da informa- } \\
\text { ção utilizando tecnologias } \\
\text { de informação. }\end{array}$ & $\begin{array}{l}\text { Tratamento, análise e agrega- } \\
\text { ção de valor às informações } \\
\text { utilizando tecnologias de infor- } \\
\text { mação. }\end{array}$ & $\begin{array}{l}\text { Agregação de valor às infor- } \\
\text { mações prospectadas, sele- } \\
\text { cionadas e filtradas. }\end{array}$ \\
\hline $\begin{array}{l}\text { Disseminação e mediação } \\
\text { da informação ao público } \\
\text { interessado. }\end{array}$ & $\begin{array}{l}\text { Transferência do conhecimen- } \\
\text { to ou socialização do conheci- } \\
\text { mento no ambiente organiza- } \\
\text { cional. }\end{array}$ & $\begin{array}{l}\text { Utilização de sistema de infor- } \\
\text { mação estratégico voltado à } \\
\text { tomada de decisão. }\end{array}$ \\
\hline $\begin{array}{l}\text { Criação e disponibilização } \\
\text { de produtos e serviços de } \\
\text { informação. }\end{array}$ & $\begin{array}{l}\text { Criação e disponibilização de de } \\
\text { sistemas de informação em- } \\
\text { presariais de diferentes natu- } \\
\text { rezas. }\end{array}$ & $\begin{array}{l}\text { Criação e disponibilização de } \\
\text { produtos e serviços específi- } \\
\text { cos à tomada de decisão. }\end{array}$ \\
\hline $\begin{array}{l}\text { Trabalha essencialmente } \\
\text { com os fluxos formais de } \\
\text { informação }\end{array}$ & $\begin{array}{l}\text { Trabalha essencialmente } \\
\text { com os fluxos informais de } \\
\text { informação }\end{array}$ & $\begin{array}{l}\text { Trabalha com os dois fluxos } \\
\text { de informação: formais e in- } \\
\text { formais. }\end{array}$ \\
\hline
\end{tabular}

Figura 4 - Gestão da Informação, Gestão do Conhecimento, Inteligência Competitiva Fonte: Valentim, M.L.P. (2002, p. 1-13)

Para explicar a relação entre os três conceitos, Valentim, M.L.P. (2002, p. 1-13) prossegue e esclarece que: "a relação entre os três conceitos existe e é natural, uma vez que dados, informação e conhecimento são insumos básicos para os três modelos".

Pela análise dos conceitos apresentados, fica claro que a Inteligência Organizacional tem como foco a tomada de decisão estratégica e para isso se utiliza tanto do processo de gestão da informação, conhecimento explícito, quanto do processo de gestão do conhecimento, conhecimento tácito.

Portanto, pode-se concluir que inteligência organizacional é a capacidade da organização sensoriar o ambiente interno e externo, captar sinais, produzir e mobilizar conhecimento para subsidiar a tomada de decisão, aumentando, assim, a capacidade institucional para resolver problemas.

\section{I PROCEDIMENTOS METODOLÓGICOS}

O presente artigo é resultado de uma pesquisa exploratória que, por meio de uma abordagem qualitativa, usou como técnicas de pesquisa revisão bibliográfica e pesquisa documental (MARCONI e LAKATOS, 2015).

$=$ Para atingir objetivos propostos, realizou-se uma pesquisa bibliográfica e documental com vistas a identificar: 
- Conceitos e reflexões sobre gestão do conhecimento e da informação.

- Conceitos e reflexões a respeito de organizações como sistemas abertos.

- Conceitos e reflexões a respeito da atuação organizacional em rede.

- Conceitos e reflexões sobre o processo de inteligência organizacional.

Procura-se, assim, apresentar os conceitos e as reflexões sobre gestão do conhecimento e da informação, inteligência organizacional, organizações como sistemas abertos e atuação organizacional em rede, no intuito de identificar convergências e sinergias sobre essas estratégias.

Posteriormente, busca-se conciliar as bases teóricas com a prática, por meio da apresentação de dois estudos de casos, que buscam evidenciar como a atuação em rede e como sistema aberto pode fortalecer o processo de inteligência organizacional e, ainda, gerar benefícios para os demais membros da rede.

Por fim, seria possível concluir que a atuação organizacional em rede e como sistema aberto pode fortalecer muito o sistema de inteligência organizacional, que os processos de gestão do conhecimento (tácito e explícito) precisam ser fortalecidos dentro das organizações para consequente melhoria do processo decisório e que para isso é essencial a criação e capacidades organizacionais para gerenciamento de recursos informacionais.

\section{I ANÁLISE}

Já discutimos que inteligência organizacional é a capacidade da organização sensoriar o ambiente interno e externo, captar sinais, produzir e mobilizar conhecimento para subsidiar a tomada de decisão, aumentando, assim, a capacidade institucional para resolver problemas.

Tendo como base essa definição, algumas perguntas devem ser realizadas diariamente pelos profissionais incumbidos do processo de inteligência organizacional, tais como:

- Quais conhecimentos são necessários para apoiar as estratégias da organização?

- Existe conhecimento na organização para responder a determinada demanda do ambiente de negócio?

- Como suprimir o hiato de conhecimento existente na organização?

- Onde está o conhecimento que necessito no ambiente externo da organização?

- Essa demanda de conhecimento é rotineira ou esporádica?

Para responder essas e outras questões o sistema de gestão do conhecimento tácito e explícito da organização deve funcionar diariamente, de modo a dar execução à política de inteligência organizacional. A obra de Moresi (2001) elenca um conjunto 
de atividades de gestão do conhecimento (tácito e explícito) que devem ser executadas para que a inteligência organizacional se efetive na prática:

- Descobrir conhecimentos (experiências, práticas otimizadas) de modo que todo indivíduo possa usá-los no contexto dos papéis da organização;

- Assegurar que o conhecimento esteja disponível com oportunidade nos locais de tomada de decisão;

- Assegurar que o conhecimento esteja disponível com oportunidade sempre que for necessário no contexto dos processos organizacionais;

- Facilitar o desenvolvimento efetivo e eficiente de conhecimentos novos (aprendizado baseado em casos históricos);

- Assegurar que os conhecimentos novos sejam distribuídos a todos os segmentos da organização envolvidos em sua utilização;

- Assegurar que todo o público interno da organização saiba onde os conhecimentos estão disponíveis e como acessá-los.

Para suprimir as necessidades de conhecimento da organização pode-se montar uma robusta estrutura de trabalho interna, que permita o sensoriamento adequado do ambiente externo e interno da instituição, realize a contextualização e interpretação dos sinais do ambiente de negócio e produza e mobilize conhecimento para subsidiar o processo de tomada de decisão.

Contudo, tal opção pode resultar em uma grande mobilização de recursos financeiros, em um processo de trabalho demasiadamente complexo e, ainda, em uma insuficiente qualidade da informação a ser fornecida para atender as necessidades de conhecimento corporativas, dada ao amplo e diversificado leque de conhecimentos necessários para prosperar e sobreviver no ambiente de negócios contemporâneos.

Em contraponto, existem organizações que já estão intimamente ligadas a determinados nichos de conhecimento, onde a interação e a integração com o ambiente de negócio a respeito de determinado eixo de política ocorre naturalmente. Assim, essas organizações possuem acesso ao conhecimento que é necessário por outra instituição de modo menos oneroso e mais eficaz.

Nesse sentido, a melhoria do processo decisório a partir da atuação em rede surge como uma excelente alternativa, permitindo que as organizações se especializem em seu proposito principal e se consorcie com outras instituições para obter com maior eficácia os conhecimentos explícitos e tácitos de maior complexidade e volatilidade. Tal configuração propicia, ainda, uma redução do tamanho das organizações e a obtenção dos conhecimentos para subsidiar a tomada de decisão com maior flexibilidade e agilidade.

Para melhor evidenciação dos conceitos e das ideias apresentadas, serão 
detalhados dois casos, baseados em iniciativas concretas instituídas por instituições públicas brasileiras. Por tais iniciativas não estarem devidamente publicadas, serão omitidos os nomes das instituições empreendedora das ações.

\title{
CASO 1 - REDE DE APOIO CIENTÍFICO
}

\begin{abstract}
Uma instituição pública brasileira possui um complexo ambiente de negócios, na qual precisa regulamentar a produção, comercialização e uso de um amplo e diversificado rol de produtos e serviços intensivos em alta tecnologia. Para conceder as autorizações de produção e comercialização dos produtos e serviços, tal organização avalia cada pedido de autorização, verificando a conformidade das informações apresentadas pelos demandantes com o regulamento que disciplina o assunto.
\end{abstract}

Contudo, a variabilidade e profundidade dos assuntos que precisam ser debatidos requer, em muitos casos, a presença de especialistas nos assuntos discutidos, tamanha a complexidade técnica e científica que regularmente o órgão se depara. Diante desse cenário, havia o entendimento de que era inviável produzir ou reunir dentro da organização todo o conhecimento para se desempenhar a função da organização.

Diante disso, essa instituição pública firmou parcerias com instituições de desenvolvimento científico e tecnológico que possuem acesso a um amplo rol de especialistas nos assuntos de maior complexidade, possibilitando o assessoramento qualificado para subsidiar a tomada de decisão. Em contrapartida, a instituição parceira recebe recursos financeiros para cobrir os custos logísticos e de remuneração aos especialistas.

Assim, a partir do sensoriamento das demandas de informação do ambiente interno, a instituição demandante apresenta as demandas de conhecimento para as instituições parceiras, que acessam o seu ambiente de negócios para captar, selecionar, interpretar e fornecer o conhecimento requisitado. Atividades de intercâmbio de conhecimento entre os parceiros também são executadas, permitindo a harmonização de conhecimentos entre todos os membros da rede.

Tal configuração permite que o órgão demandante melhore o seu processo decisório e, ainda, aumente a sua capacidade produtiva, a partir da descentralização de atividades de captação, seleção e interpretação de conhecimentos para subsidiar a tomada de decisão. Já as instituições parceiras conseguem cumprir sua missão institucional, desenvolvimento científico e tecnológico, permitindo sua maior integração no seu ambiente de negócios por meio da troca de informações (insumos) com maior intensidade.

\section{CASO 2 - REDE DE INOVADORES TECNOLÓGICOS}

Uma instituição pública brasileira possui como atribuição regular a produção e comercialização de produtos e serviços no campo da saúde. Para isso, precisa deter o conhecimento a respeito desses produtos e serviços, no intuito de produzir regulamentos eficazes para garantir a segurança e eficácia dos produtos e serviços que serão postos à disposição da sociedade brasileira para consumo.

Contudo, no caso de tecnologias inovadoras, existe uma grande assimetria de informações, pois trata-se de conhecimento novo e altamente especializado que foi gerado pelo mercado e que até então está sob domínio dos desenvolvedores da tecnologia. Nesse cenário, o governo possui acesso muito limitado ao conhecimento adequado para regular o consumo de tais pro- 
dutos, exigindo, quase que exclusivamente, o contato com os desenvolvedores para acessar tal conhecimento.

Para solucionar esse problema, a instituição pública realizou um sensoriamento dos hiatos de conhecimento sobre tecnologias inovadoras e lançou um edital de chamamento externo, convidando os desenvolvedores que detinham o domínio sobre determinada tecnologia a receberem os servidores do órgão e proporcionar a eles o contato direto com a tecnologia, propiciando, assim, a reunião de informações para subsidiar a tomada de decisão a respeito de novos regulamentos.

Os desenvolvedores possuem muito interesse no repasse do conhecimento, pois a produção de regulamentos desconexos com a realidade impõe dificuldades na comercialização dos produtos e serviços, gerando impactos negativos no desempenho econômico da empresa. Assim, trata-se de uma relação de parceria, sem finalidade lucrativa, sem nenhuma relação de autoridade e com benefícios recíprocos.

Para que a transferência de conhecimento ocorresse, os desenvolvedores sensoriavam todo o ambiente para reunir todo o conhecimento explícito e tácito a respeito do assunto, proporcionando, ainda, a experiência do servidor com a tecnologia, quando o mesmo poderia experimentar sensações e confrontá-las com o conhecimento que era apresentado pelos desenvolvedores.

Destaca-se que os desenvolvedores também eram beneficiados com o conhecimento da organização pública participante, pois em meio às discussões eles podiam melhor se apropriar do arcabouço de regras e diretrizes de governo, o que pode resultar em um melhor padrão de desenvolvimento de novos produtos e serviços.

Portanto, em um cenário de quase inviabilidade de acesso ao conhecimento por meios próprios, lançou-se mão de uma estratégia de atuação em rede para acessar dados, informações e conhecimentos, o que refletiu em uma melhora do processo decisório e em uma atuação mais legitima frente ao mercado de desenvolveres de tecnologias inovadoras.

Os dois casos apresentados evidenciam como a capacidade de mobilização de conhecimento da organização foi maximizada a partir da atuação em rede, pois a cooperação de instituições especialistas em determinados nichos de conhecimento refletiu em uma maior capacidade de captar, selecionar e interpretar dados, conhecimentos e informações, proporcionando maior flexibilidade, agilidade e efetividade no processo decisório.

Para uma adequada atuação em rede, também é necessária a criação de um ambiente que assegure os direitos e deveres de cada parte, sem causar lentidão e falta de flexibilidade. Nesse aspecto, cabe ressaltar um grande desafio para o governo, ainda marcado por uma forte cultura burocrática, que é criar instrumentos legais que permita a atuação em rede de modo adequada, rompendo com a série de controles prévios e amarras burocráticas.

Além disso, a atuação em rede, detalhada nos dois casos, também demonstra a atuação da organização como um sistema aberto, fornecendo e recebendo insumos do seu ecossistema, o que reflete em uma maior legitimidade em sua atuação, a partir do 
momento em que fortalece o seu processo de mobilização de conhecimento (explícito e tácito) para subsidiar a tomada de decisão.

Destaca-se também o processo de gestão do conhecimento explícito e tácito, coordenados pelas instituições parceiras, seja no sensoriamento do ambiente interno de cada organização, seja na captação, seleção e interpretação de dados, informações e conhecimentos do ambiente externo, visando identificar hiatos de conhecimento e a reunião das melhores evidências para a tomada de decisão.

Por fim, pela análise dos dois casos, fica evidente como a atuação em rede pode otimizar os esforços de captação, seleção e interpretação de dados, informações e conhecimentos e, mais do que isso, resultar em benefícios para outros membros do ecossistema, gerando desenvolvimento não apenas corporativo, mas em todo um segmento da sociedade.

\section{I CONSIDERAÇÕES FINAIS}

Uma cultura organizacional voltada para o trabalho em rede requer, em especial no governo, um ambiente legal propício para esse tipo de atuação. O tradicional modelo burocrático, repleto de amarras e controles prévios, não proporciona as condições necessárias para uma atuação flexível, ágil e horizontal, características do trabalho em rede.

Nas últimas décadas o governo brasileiro criou instrumentos que permitem uma maior flexibilidade na execução de ações, como o Termo de Execução Descentralizada, que permite a descentralização de recursos para outro órgão público federal desempenhar atividades de modo descentralizado. Apesar dos esforços, o governo ainda carece de instrumentos legais mais adequados à sociedade do conhecimento, que se sobreponha à forte cultura burocrática e, enfim, permita uma atuação mais ágil, flexível e eficaz.

Em um ambiente de negócios cada vez mais complexo, reunir e combinar de modo inteligente dados, informações e conhecimentos para subsidiar o processo de tomada de decisão se torna essencial. Para isso, além do desenvolvimento da capacidade organizacional de atuar em rede e como sistema aberto, é necessário a criação de capacidade organizacional para gerir recursos informacionais, de modo a abastecer a organização com o conhecimento necessário para manter sua sobrevivência e prosperidade.

Aumentar a capacidade de resolução de problemas da organização passa, sem dúvida alguma, pela capacidade de reunir e combinar dados, informações e conhecimentos, razão pela qual esses ativos são insumos indissociáveis e complementares no ambiente organizacional. Por isso, é fundamental a existência de processos de inteligência organizacional que contemple o gerenciamento desses ativos. 
Atuar em rede e como sistema aberto fortalece muito os processos de inteligência organizacional, pois uma maior integração com o ambiente permite uma maior troca de insumos, facilitando a captação de sinais de mudança. Além disso, o processo de cooperação em rede faz com o que o desenvolvimento de uma instituição fortaleça a outra, gerando resultados positivos recíprocos.

\section{REFERÊNCIAS}

BARBOSA, Ricardo Rodrigues. Gestão da informação e do conhecimento: origens, polêmicas e perspectivas. Informação \& Informação, 2008, 13.1esp: 1-25.

BELUZZO, R. C. B.; FERES, G.G. A mediação da informação para o setor produtivo como recurso estratégico na sociedade do conhecimento. In: SIMPÓSIO DE ENGENHARIA DE PRODUÇÃO (Simpep), 10, 2003, Bauru. Anais. Bauru, 2003.

DAVENPORT, T.; PRUSAK, L. Conhecimento empresarial: como as organizações gerenciam seu capital intelectual. Rio de Janeiro: Campus, 1998.

De Masi, Domenico. A sociedade pós-industrial. Trad. Anna Maria Capovilla et al. Sao Paulo: SENAC, 1999.

JERMOL, M.; LAVRAČ, N.; URBANČIČ, T. Managing business intelligence in a virtual enterprise: a case study and knowledge management lessons learned. Journal of Intelligent \& Fuzzy Systems, n. 14, p. 121-136, 2003.

LEV, B. Sharpening the Intangibles Edge. Harvard Business Review, p. 108-116, Jun. 2004.

LÉVY, P. As tecnologias da inteligência: o futuro do pensamento na era da informática. Rio de Janeiro: Editora 34, 1993.

MARCONI, Marina de Andrade; LAKATOS, Eva Maria. Técnicas de Pesquisa. $7^{a}$ ed. São Paulo: Atlas, 2015.

METCALFE, Les. "Cotejando las capacidades gerenciales con las cambiantes necesidades de la integración”. Revista del Clad. n. 9, octubre, 1997.

Miguelleto, D. C. R. (2001). Organizações em rede (Doctoral dissertation).

Moresi, Eduardo Amadeu Dutra. "Inteligência organizacional: um referencial integrado." Ciência da informação 30.2 (2001).

NONAKA, I., TAKEUCHI, H. Criação de conhecimento na empresa: como as empresas japonesas geram a dinâmica da inovação. Rio de Janeiro: Campus, 1997.

OWEN, John M. Dnowledge Management and the Information Professional. Information Services \& Use. 19, n. 1: 7-16. 1999. Disponível em: http://cf.hum.uva.nl/bai/home/jmackenzie/pubs/km-kim99. htm

PONJUÁN DANTE, G. Gestión de información en las organizaciones: principios, conceptos y aplicaciones. Santiago de Chile: CECAPI - Centro de Capacitación en Información, Universidad de Chile, 1998.

PRUSAK, L. Where did knowledge management came from? IBM Systems Journal, Armonk, v. 40, n. 4, p. 1002-1007, 2001.

T a p s c o t t , Don. Growing up digital: the rise of the Net generation. Nova York: McGraw Hill, 
1997.

e CASTON, Art. Mudança de paradigma. Trad. Pedro Catunda. Sao Paulo: Macron

Books do Brasil, 1995.

Tarapanoff, Kira. Inteligência, informação e conhecimento em corporações. Instituto Brasileiro de Informação em Ciência e Tecnologia (IBICT), 2006.

Valentim, Marta Lígia Pomim, and BMN CERVANTES. "O processo de inteligência competitiva em organizações." DataGramaZero, Rio de Janeiro 4.3 (2003): 1-23.

Valentim, Marta Lígia Pomim. "Inteligência competitiva em organizações: dado, informação e conhecimento." DataGramaZero, Rio de Janeiro 3.4 (2002): 1-13.

VALENTIM, Marta. "Informação e conhecimento no contexto de ambientes

organizacionais." Gestão, mediação e uso da informação (2010): 235.

WILSON, T. D. Information Management. In: INTERNATIONAL ENCYCLOPEDIA OF INFORMATION AND LIBRARY SCIENCE. London: Routledge, 1997. p. 187-196.

WOIDA, L.M.; VALENTIM, M.L.P. Cultura informacional: um modelo de realidade social para a ICO. In: VALENTIM, M.L.P. (Org.) Gestão da informação e gestão do conhecimento no âmbito da Ciência da Informação. São Paulo: Polis; Cultura Acadêmica, 2008. P. 117-27. 


\section{PERFIL E POTENCIAL EMPREENDEDOR DE ALUNOS INGRESSANTES DE UMA INSTITUIÇÃO FEDERAL}

Data de aceite: 11/03/2020

Fabiano Palhares Galão Universidade Tecnológica Federal do Paraná,

Brasil,fpgalao@gmail.com

Marcia Cristina Alves

Universidade Tecnológica Federal do Paraná,

Brasil,marciaalves@utfpr.edu.br

Maria Gabriela Menezes

Universidade Tecnológica Federal do Paraná,

Brasil, mariagabimenezes@hotmail.com

Rubem Gabriel M. da Costa

Universidade Tecnológica Federal do Paraná,

Brasil, rubemgabriel_gm@hotmail.com

João Dallamuta

UTFPR - Universidade Tecnológica Federal do

Paraná, Brasil, joaol@utfpr.edu.br

RESUMO: Este estudo teve por objetivo identificar e discutir o perfil e o potencial empreendedor de alunos ingressantes de uma instituição federal. $O$ estudo foi realizado com alunos ingressantes dos cursos de Engenharia da Universidade Tecnológica Federal do Paraná (UTFPR). A pesquisa é caracterizada como descritiva de abordagem quantitativa. A amostra contemplou 155 alunos ingressantes dos quatro cursos de engenharia existes na instituição. Os resultados apontaram que uma quantidade significativa de alunos possui alguém da família envolvido em atividades empreendedoras, fator que pode influenciar positivamente os alunos na opção em seguir o caminho de empreender. Para boa parte da amostra, a prática empreendedora seria uma opção satisfatória, entretanto, dada a pouca experiência em gestão de empresas e no mundo dos negócios, a maior parte acredita que ainda não é o momento certo para se pensar nisso. Percebeu-se que os alunos entrevistados possuem um alto grau de expectativa do curso e da instituição no que diz respeito ao inventivo à prática de empreender. Esse dado revela a responsabilidade que os dirigentes da instituição possuem em atender a essas expectativas por meio da realização das mais diversas atividades que cercam o tema empreendedorismo.

PALAVRAS-CHAVE: Empreendedorismo; perfil empreendedor; potencial empreendedor.

\section{PROFILE AND ENTREPRENEURIAL POTENTIAL OF INCOMING STUDENTS FROM A FEDERAL INSTITUTION}

ABSTRACT: This study aimed to identify and discuss the profile and entrepreneurial potential of incoming students from a federal institution. The study was carried out with students entering the Engineering courses of the Federal 
Technological University of Paraná (UTFPR). The research is characterized as descriptive of quantitative approach. The sample included 155 incoming students from the four engineering courses that exist in the institution. The results showed that a significant number of students have someone from the family involved in entrepreneurial activities, a factor that can positively influence students in choosing the path to be undertaken. For a good part of the sample, entrepreneurship practice would be a satisfactory option, however, given the limited experience in business management and business, most believe that the time is not yet right to think about it. It was noticed that the students interviewed have a high degree of expectation of the course and of the institution with respect to the inventive to the practice of undertaking. This data reveals the responsibility that the leaders of the institution have in meeting these expectations through the accomplishment of the most diverse activities that surround the theme of entrepreneurship.

KEYWORDS: Entrepreneurship; entrepreneurial profile;entrepreneurial potential.

\section{I INTRODUÇÃO}

O empreendedorismo é caracterizado como uma atividade essencial para o desenvolvimento econômico e social de uma região, uma vez que a ação empreendedora desempenhada por aquele que a coloca em prática, ou seja, o empreendedor, propicia a geração de riquezas, emprego e renda e inúmeros benefícios para a sociedade.

Diante deste fato já consolidado e sendo o empreendedorismo amplamente discutido e incentivado, é natural que o tema faça parte do mundo dos negócios, mas também de outras organizações da sociedade, em especial das instituições de ensino, sejam elas públicas ou privadas, de nível básico, técnico, ou profissionalizante e, de modo acentuado, no ensino superior (ROCHA e FREITAS, 2014; DOLABELA, 2008).

O presente artigo focaliza o empreendedorismo nas instituições de ensino superior (IES) uma vez que este ambiente, segundo Fernandes, Moreira e Pereira (2015) e Santos, Pilatti e Vlastuin (2005) é um local adequado para despertar, desenvolver ou fomentar empreendedores. Nesse sentido, Masiero (2007) lembra que o ensino do empreendedorismo, durante a formação de um novo profissional, tem sido considerado vital para melhorar o desempenho das empresas e que diversas universidades brasileiras incluem nos seus currículos a disciplina de empreendedorismo, buscando estimular e favorecer a geração de novos empreendimentos. De modo geral, apoós um estuante cursar uma disciplina de empreendedoriso, é esperado que os seguintes aspectos sejam desenvolvidos: i) o interesse pelo tema; ii) o gosto pela ideia de empreender; iii) os caminhos para a prática do empreendedorismo e, iv) algum nível de interesse para empreender um negócio próprio. Athayde e Martins (2012) seguem nessa linha e apresentam preocupação com a forma pela qual o empreendedorismo deve ser estimulado, sobretudo entre os jovens, com o objetivo de estimular o empreendedorismo por vocação.

Já na perspectiva de Araújo (2014), por meio do ensino do empreendedorismo, os 
alunos são apresentados a uma alternativa de futuro profissional, além de desenvolver habilidades e competências que serão úteis em qualquer carreira.

Além de existir como um componente curricular, o empreendedorismo é incentivado por meio de seminários, cursos extras, debates e em muitos casos pela existência de espaços destinados ao estabelecimento e desenvolvimento de negócios, como as incubadoras tecnológicas (ROCHA e FREITAS, 2014)

Muito embora é perceptível a preocupação das IES no sentido de desenvolver habilidades, competências e uma cultura empreendedora em seus alunos, esse processo pode se tornar pouco eficaz se não houver um entendimento por parte das IES do perfil e do potencial empreendedor dos alunos, especialmente dos ingressantes, os quais estarão em contato com a universidade por vários anos. Este estudo defende que isso é um aspecto relevante para que as IES possam conhecer um pouco sobre as atividades desenvolvidas pelos alunos antes do ingresso na universidade, as influências empreendedoras existentes nas suas famílias e, especialmente, seus interesses em empreender um negócio próprio.

Além disso, conhecer as expectativas dos alunos em relação ao o que ele espera da instituição enquanto agente de disseminação de conhecimento e desenvolvimento profissional também é um fator de análise interessante, pois, uma vez conhecidos os anseios dos jovens estudantes em relação ao papel da IES ao empreendedorismo, a instituição poderá desenvolver seus currículos e atividades de ensino direcionadas ao empreendedorismo com maior assertividade podendo, com isso, existir um melhor alinhamento daquilo que se propõe nos projetos pedagógicos dos cursos e das demais atividades relacionadas ao empreendedorismo com os anseios dos discentes. lizuka e Moraes (2014) defendem que a compreensão do histórico, dos interesses e das expectativas dos alunos é necessário para aqueles que atuam com empreendedorismo, em especial, no campo do ensino e aprendizagem.

Diante desse contexto, surge o problema central do presente estudo que é: Qualo perfil e o potencial empreendedor dos alunos ingressantes de uma instituição federal? A partir da formulação da questão que norteia o estudo, tem-se que seu objetivo central é identificar e discutir o perfil e o potencial empreendedor de alunos ingressantes de uma instituição federal.

O presente estudo possui relevância significativa na área que está inserido, pois, poderá gerar subsídios para que as instituições de ensino possam empregar novas práticas de ensino com o objetivo de aprimorar o estímulo à formação de uma postura empreendedora em seus alunos. O presente trabalho propõe-se ainda a servir de base científica para essa análise e contribuir para futuras discussões acerca de potencial empreendedor nos cursos de graduação. 


\section{I REFERENCIAL TEÓRICO}

\subsection{Empreendedorismo}

O empreendedorismo está cada vez mais em evidência em diversos países e contextos, sendo um tema amplamente discutido no meio empresarial, governamental, educacional e também por instituições de caráter não lucrativo que apoiam e disseminam a prática e a cultura empreendedora. É reconhecido como fundamental para o desenvolvimento de novos negócios, para a geração de renda e empregos, e por consequência, para a melhoria da qualidade de vida da sociedade. Para Masiero (2007), o empreendedorismo se estabelece como um fenômeno cultural, fortemente relacionado e embasado no processo educacional, o qual age como mola propulsora da criação de pequenas e médias empresas, muitas delas consideradas inovadoras de base tecnológica.

A origem do termo pode ser compreendida a partir dos escritos de Gomes (2005), a qual explica que empreendedorismo ou empreendedor são substantivos derivados do verbo empreender que, por sua vez, tem sua origem na forma verbal latina imprehendo ou impraehendo que significa "tentar executar uma tarefa". A referida autora finaliza que a entrada desse termo no léxico português não se deu através do francês entrepreneur (como se encontra em diversas referências ao tema), mas sim diretamente do latim.

É comum encontrar na literatura autores que apresentam as raízes histórias do empreendedorismo, como Dornelas (2008) e Hisrich, Peters e Shepherd (2009), os quais trazem a contribuição de pensadores considerados pioneiros na disseminação do conceito de empreendedorismo e da figura do empreendedor, bem como as diferentes vertentes relacionadas ao tema, uma vez que parece não haver consenso sobre como de fato pode-se conceituar o termo. A respeito disso, Gomes (2005) explica que existem muitas definições sobre empreendedorismo advindas de estudiosos que utilizam princípios de suas respectivas áreas de conhecimento e interesse para elaborar o conceito.

No entanto, Fillion (1999) apresenta duas correntes de pensamento a respeito do que ele chama de "universo do empreendedor": a primeira, oriunda dos pioneiros sobre a temática, que foram os economistas, e a segunda corrente, representada pelos comportamentalistas. No primeiro caso, o empreendedorismo é relacionado com a inovação e o empreendedor é visto como um agente de mudança capaz de identificar oportunidades de negócio. Nesta corrente é creditado a Schumpeter (1883-1950) como aquele que deu projeção ao tema, associando de forma definitiva o empreendedor ao conceito de inovação.

$\mathrm{Na}$ segunda visão, a dos comportamentalistas (psicólogos, sociólogos e especialistas em comportamento), o empreendedorismo é baseado em aspectos atitudinais, como a criatividade e a intuição. Filion (1999) atesta que nesta corrente o autor 
que iniciou a contribuição das ciências do comportamento para o empreendedorismo foi David C. McClelland (1917-1998).

Daft (2010) empreendedorismo é o processo de iniciar um negócio de risco, organizando os recursos necessários e assumindo os riscos e as recompensas associados. Um empreendedor reconhece uma ideia viável para ser transformada em um negócio, seja uma indústria ou uma prestadora de serviços e reúne os diferentes recursos para iniciar o negócio.

\subsection{Potencial e Perfil Empreendedor}

As mais diversas atividades realizadas pelos estudantes universitários antes do ingresso no curso superior, bem como as influências de amigos e, especialmente da família, são elementos que provavelmente podem influenciar no potencial empreendedor desses indivíduos (IIZUKA e MORAES, 2014; SANTOS, 2008). Nesse sentido, Daft (2010) assevera que os empreendedores possuem históricos de vida e características demográficas que os distinguem de outras pessoas e que o mais provável é que a maioria dos empreendedores sejam o primogênito em suas famílias e seus pais provavelmente foram empreendedores.

Sobre a influência da família, Silva et al (2013) mostram que existem evidências de que os empreendedores tendem a ter pais também empreendedores, pois, ter pais que trabalham por conta própria propicia uma inspiração para o empreendedor. Os resultados da pesquisa de Bohnenberger, Schmid e Freitas (2007) mostraram que o perfil empreendedor possui associação com o contexto familiar, corroborando o que foi encontrado na literatura. Já Almeida e Teixeira (2014) atestam que a família desempenha um papel importante na formação do comportamento empreendedor, pois as relações afetivas vividas na infância podem refletir em algumas das atitudes desenvolvidas nessas pessoas quando adultas.

lizuka e Moraes (2014) destacam diferentes atividades que em algum momento e em maior ou menor grau, fizeram-se presentes na história dos estudantes e podem influenciar o potencial empreendedor, como por exemplo, a convivência com amigos, as experiências em diferentes ambientes, tais como igreja, clube, movimentos estudantis, políticos e sociais, trabalhos voluntários em ONGs, centros cívicos, entre outras.

Santos (2008), por sua vez, destaca a experiência profissional do empreendedor, a aquisição de conhecimento via capacitações formais e pela experiência vivenciada no dia-a-dia, como fatores que podem ampliar as possibilidades de sucesso na atividade empresarial. O estudo de Almeida et al (2008) buscou avaliar a influência do ensino do empreendedorismo no curso de Administração no potencial empreendedor dos alunos de duas universidades. Uma das conclusões foi a de que o ensino do empreendedorismo só despertou o desejo de empreender em quem já possuía condições sociais e culturais favoráveis para isso. Além disso, o fato de existir algum 
empreendedor próximo ao estudante também contribuiu para despertar o desejo de empreender.

Em relação ao perfil empreendedor é possível encontrar uma grande variedade de trabalhos acadêmicos, os quais buscam, segundo Rocha e Freitas (2014), identificar as características e competências comuns encontradas em indivíduos que atuam de acordo com as prerrogativas empreendedoras relatadas na literatura. Dentre essas iniciativas pode-se citar os estudos de Santos (2008), Rocha e Freitas (2014), Veiga e Parreira (2015), Hecke (2011) e Dias, Souza Neto e Boas (2010).

Bohnenberger, Schmidt e Freitas (2007) colaboram com este entendimento ao dizerem que o estudo do perfil empreendedor não é novidade, e que existem revistas acadêmicas internacionais, como Entrepreneurship Theory and Practice e Entrepreneurship and Regional Development, que são exclusivas para este fim.

$\mathrm{O}$ interesse pelo entendimento sobre quais as características que modelam o perfil empreendedor pode ser constatado pelos resultados do levantamento realizado por Silva et al (2013), o qual detectou que as características inerentes ao empreendedor foi o tema mais pesquisado nos estudos publicados nos anais do EnAnpad entre 2003 e 2012.

Araújo (2014) destaca a importância em se conhecer o perfil do jovem empreendedor, pois com isso, é possível formular e implantar novas políticas públicas e metodologias de ensino que fomentem e ampliem a educação empreendedora.

O estudo de Schmidt e Bohnenberger (2009) teve por objetivo a construção e validação de um instrumento de medição do perfil empreendedor e sua relação com o desempenho organizacional. Após pesquisa na literatura, os referidos autores definiram oito constructos das características do perfil empreendedor, as quais foram conceituadas para sustentar o processo de elaboração do instrumento de medição. $O$ quadro 1 apresenta essas oito características e seus conceitos.

\begin{tabular}{|l|l|}
\hline \multicolumn{1}{|c|}{ CARACTERÍSTICA } & \multicolumn{1}{c|}{ DESCRIÇÃo } \\
\hline Auto-eficaz & $\begin{array}{l}\text { Refere-se à estimativa cognitiva que uma pessoa tem das suas capa- } \\
\text { cidades de mobilizar motivação, recursos cognitivos e cursos de ação } \\
\text { necessários para exercitar controle sobre eventos na sua vida. }\end{array}$ \\
\hline $\begin{array}{l}\text { Assume riscos } \\
\text { calculados }\end{array}$ & $\begin{array}{l}\text { Pessoa que, diante de um projeto pessoal, relaciona e analisa as variá- } \\
\text { veis que podem influenciar o seu resultado, decidindo, a partir disso, a } \\
\text { continuidade do projeto. }\end{array}$ \\
\hline Planejador & Pessoa que se prepara para o futuro. \\
\hline Detecta oportunidades & $\begin{array}{l}\text { Habilidade de capturar, reconhecer e fazer uso efetivo de informações } \\
\text { abstratas, implícitas e em constante mudança. }\end{array}$ \\
\hline Persistente & $\begin{array}{l}\text { Capacidade de trabalhar de forma intensiva, sujeitando-se até mesmo a } \\
\text { privações sociais, em projetos de retorno incerto. }\end{array}$ \\
\hline Sociável & Grau de utilização da rede social para suporte à atividade profissional. \\
\hline Inovador & $\begin{array}{l}\text { Pessoa que relaciona ideias, fatos, necessidades e demandas de merca- } \\
\text { do de forma criativa. }\end{array}$ \\
\hline Líder & $\begin{array}{l}\text { Pessoa que, a partir de um objetivo próprio, influencia outras pessoas a } \\
\text { adotarem voluntariamente esse objetivo. }\end{array}$ \\
\hline
\end{tabular}




\section{I METODOLOGIA}

Para atingir o objetivo proposto nessa pesquisa realizou-se um estudo descritivo (MALHOTRA, 2006), com abordagem quantitativa (HAIR JUNIOR et al, 2005). Quanto ao tempo, o estudo é caracterizado como transversal, pois de acordo com Freitas et al. (2000) a coleta dos dados ocorre em um só momento, pretendendo descrever e analisar o estado de uma ou várias variáveis em um dado momento.

Por questões de conveniência dos pesquisadores optou-se por realizar o estudo com alunos da Universidade Tecnológica Federal do Paraná (UTFPR), Câmpus Apucarana-PR. Além disso, é oportuno registrar que neste câmpus o empreendedorismo é incentivado e institucionalizado no âmbito de atividades, como o Hotel Tecnológico, que funciona como uma pré-incubação de projetos de alunos e professores, por meio da realização de eventos e ações ligados ao tema e ainda, com a oferta da disciplina de empreendedorismo em praticamente todos os cursos de graduação.

A amostra pesquisada contemplou alunos ingressantes dos quatro cursos de engenharia existes no câmpus no período da realização da coleta de dados: Engenharia Civil, Engenharia Elétrica, Engenharia Química e Engenharia Têxtil.

Foram aplicados 155 questionários em sala de aula durante a segunda semana do mês de novembro de 2018 , o que correspondeu a $78 \%$ do total de ingressantes no segundo semestre do mesmo ano, que foi de 199 alunos. A tabela 1 apresenta quantidade de respondentes por curso e o percentual em relação ao total de ingressantes. A diferença se explica pelo fato de que nem todos os alunos matriculados no início do semestre estavam presentes no momento da aplicação do questionário.

\begin{tabular}{ccc} 
CURSO & $\begin{array}{c}\text { QUESTIONÁRIOS } \\
\text { APLICADOS }\end{array}$ & $\begin{array}{c}\text { \% RELAÇÃO } \\
\text { INGRESSANTES }\end{array}$ \\
\hline Engenharia Civil & 36 & $\mathbf{7 0 \%}$ \\
\hline Engenharia Elétrica & 37 & $\mathbf{7 8 \%}$ \\
\hline Engenharia Química & 40 & $\mathbf{7 8 \%}$ \\
\hline Engenharia Têxtil & 42 & $\mathbf{8 4 \%}$ \\
\hline Total & $\mathbf{1 5 5}$ & $\mathbf{7 8 \%}$ \\
\hline
\end{tabular}

Tabela 1 - Distribuição dos questionários aplicados

O questionário foi dividido em duas partes, sendo que na primeira buscou-se coletar informações básicas de perfil do respondente, bem como identificar o potencial empreendedor por meio do levantamento das atividades que o aluno desenvolveu antes de ingressar na universidade e se o aluno possui ou não parentes com negócio próprio. 
A segunda parte do questionário foi formada por quinze questões do tipo Likert de seis pontos, sendo que as doze primeiras buscaram identificar o perfil empreendedor dos alunos e as demais tiveram o objetivo de avaliar as expectativas deles em relação à universidade e ao curso no que diz respeito às atividades de empreendedorismo e a própria intenção do aluno em engajar-se em atividades extracurriculares.

As questões do tipo Likert foram baseadas no estudo de lizuka \& Moraes (2014), os quais desenvolveram um modelo de medição que analisou o potencial e perfil empreendedor do estudante de administração e o ambiente universitário a partir dos estudos de Hecke (2011) e de Bohnenberger, Schmidt \& Freitas (2007). Os indicares do perfil empreendedor utilizados nesta pesquisa foram: necessidade de realização, inovador, detecta oportunidades, sociável e rede de contatos, autoconfiança, autoeficaz, liderança e persuasão, persistência, planejador e assume riscos calculados. Os conceitos de cada indicador encontram-se no quadro 2

\begin{tabular}{|c|c|}
\hline CARACTERÍSTCA & DESCRIÇÃO \\
\hline $\begin{array}{l}\text { Ser um empreendedor implicaria grande satisfação } \\
\text { para mim - Necessidade de Realização e Inovador }\end{array}$ & $\begin{array}{l}\text { Quanto maior a satisfação do estudante em ser } \\
\text { empreendedor, aumenta-se a tendência para } \\
\text { que o aluno seja empreendedor }\end{array}$ \\
\hline $\begin{array}{l}\text { Creio que tenho uma boa habilidade em detectar } \\
\text { oportunidades de negócio no mercado - Detecta } \\
\text { Oportunidades }\end{array}$ & $\begin{array}{l}\text { O fato de o aluno ter facilidade em detectar opor- } \\
\text { tuni- } \\
\text { dades de negócio as chances para que se } \\
\text { torne empreendedor são maiores }\end{array}$ \\
\hline $\begin{array}{l}\text { Conheço várias pessoas que me poderiam auxiliar } \\
\text { profissionalmente, caso eu precisasse - Sociável e } \\
\text { Rede de Contatos }\end{array}$ & $\begin{array}{l}\text { Quanto maior e melhor for a rede de contatos } \\
\text { profis- } \\
\text { sionais indicam que o estudante possui } \\
\text { melhores chances para empreender }\end{array}$ \\
\hline $\begin{array}{l}\text { Iniciar uma empresa e mantê-la funcionando seria } \\
\text { fácil para mim - Auto-eficaz e }\end{array}$ & $\begin{array}{l}\text { A autoconfiança para iniciar um negócio e pos- } \\
\text { suir os conhecimentos práticos para abrir e gerir } \\
\text { uma empre- }\end{array}$ \\
\hline Autoconfiança & $\begin{array}{l}\text { sa indicam que o estudante tem mais chances } \\
\text { para empreender }\end{array}$ \\
\hline $\begin{array}{l}\text { Eu conheço os detalhes práticos necessários para } \\
\text { criar uma empresa - Auto-eficaz e } \\
\text { Autoconfiança }\end{array}$ & $\begin{array}{l}\text { A autoconfiança para iniciar um negócio e pos- } \\
\text { suir os conhecimentos práticos para abrir e gerir } \\
\text { uma empresa indicam que o estudante tem } \\
\text { mais chances para empreender }\end{array}$ \\
\hline $\begin{array}{l}\text { Nas atividades que executo, normalmente influen- } \\
\text { cio a opinião de outras pessoas a respeito de um } \\
\text { determinado assunto - } \\
\text { Liderança e Persuasão }\end{array}$ & $\begin{array}{l}\text { A capacidade de liderança, praticada por meio } \\
\text { da persuasão e influência sobre as pessoas, é } \\
\text { um dos indicadores de que a pessoa tem me- } \\
\text { lhores possibilidades para empreender }\end{array}$ \\
\hline $\begin{array}{l}\text { Frequentemente as pessoas pedem minha opinião } \\
\text { sobre os assuntos de trabalho - } \\
\text { Liderança e Persuasão }\end{array}$ & $\begin{array}{l}\text { A capacidade de liderança, praticada por meio } \\
\text { da persuasão e influência sobre as pessoas, é } \\
\text { um dos indicadores de que a pessoa tem me- } \\
\text { lhores possibilidades para empreender }\end{array}$ \\
\hline $\begin{array}{l}\text { Profissionalmente, me considero uma pessoa muito } \\
\text { mais persistente que as demais - } \\
\text { Persistência }\end{array}$ & $\begin{array}{l}\text { Persistir diante dos problemas e desafios profis- } \\
\text { sio- } \\
\text { nais indica que o estudante possui mais } \\
\text { condições para empreender }\end{array}$ \\
\hline
\end{tabular}




\begin{tabular}{|l|l|}
\hline $\begin{array}{l}\text { No meu trabalho e/ou estudo, sempre planejo muito } \\
\text { bem tudo o que faço - Planejador }\end{array}$ & $\begin{array}{l}\text { Quanto mais o estudante planeja suas ativida- } \\
\text { des, melhores são as suas chances de empreen- } \\
\text { der }\end{array}$ \\
\hline $\begin{array}{l}\text { Eu assumiria uma dívida de longo prazo, acredi- } \\
\text { tando nas vantagens que uma oportunidade de } \\
\text { negócio me traria - Assume } \\
\text { Riscos Calculados }\end{array}$ & $\begin{array}{l}\text { Empreender envolve riscos e quanto maior for o } \\
\text { interesse em assumi-los tende-se a indicar um } \\
\text { perfil mais empreendedor. }\end{array}$ \\
\hline $\begin{array}{l}\text { Relaciono-me muito facilmente com } \\
\text { outras pessoas - Sociável }\end{array}$ & $\begin{array}{l}\text { O grau de facilidade em se relacionar com as } \\
\text { pessoas é um elemento que aumentam as } \\
\text { chances para empreender }\end{array}$ \\
\hline $\begin{array}{l}\text { Tenho a firme intenção em criar uma empresa em } \\
\text { breve - Necessidade de Realização e } \\
\text { Auto-eficaz }\end{array}$ & $\begin{array}{l}\text { O fato de o aluno querer concretizar suas ideias } \\
\text { indica que ele possui um conceito positivo de } \\
\text { eficácia sobre si próprio e de que busca concre- } \\
\text { tizar seus planos e quanto maior for a intenção } \\
\text { em abrir uma empresa, mais empreendedor é o } \\
\text { estudante }\end{array}$ \\
\hline
\end{tabular}

Quadro 2 - Perfil e potencial empreendedor Fonte: lizuka \& Moraes (2014)

Os indicadores utilizados para avaliar as expectativas dos alunos em relação à universidade e ao curso no que diz respeito às atividades de empreendedorismo e a própria intenção do aluno em engajar-se em atividades extracurriculares contemplou as seguintes questões: i) expectativa dos alunos em relação ao auxílio do curso em empreender, ii) expectativa dos alunos em relação ao ambiente da universidade em questões ligadas ao empreendedorismo e, iii) pretensão do aluno em participar de atividades extracurriculares.

A análise dos dados feita por meio de estatística descritiva e os resultados da pesquisa foram analisados com o auxílio do software SPSS versão 18.

\section{I ANÁLISE DOS RESULTADOS}

Dos 155 alunos que responderam o questionário, $67,1 \%$ eram do sexo masculino e $32,9 \%$ do sexo feminino. Devido ao perfil da amostra, alunos ingressantes em uma universidade, a maior parte dos respondentes pertencia à faixa etária de 18 a 21 anos $(61,9 \%)$.

Das atividades desenvolvidas antes do ingresso na universidade os destaques foram: grupos religiosos $(52,3 \%)$, trabalho em empresas de terceiros $(36,1 \%)$, trabalho voluntário (34,2\%), trabalho em empresa familiar (29\%) e participação em movimentos estudantis (26,5\%). Para lizuka \& Moraes (2014) esses indicadores são relevantes para compreender o potencial empreendedor, na medida em que se trata de experiências e iniciativas concretas dos jovens anteriores ao período universitário.

Os resultados da questão que buscou identificar se os alunos possuíam ou não parentes com negócio próprio apontou que $74,8 \%$ da amostra possui parentes empreendedores, sendo que, deste total, a maior parte, $40,6 \%$, correspondem aos pais $(22,6 \%)$, mães $(7,7 \%)$ e ao casal $(10,3 \%)$ e o restante $(34,2 \%)$ são outros parentes, como avós, tios ou irmãos. Esse resultado pode ser favorável no sentido de incentivar os alunos em optar por empreender um negócio próprio no futuro. Sobre a influência 
da família, Bohnenberger, Schmidt e Freitas (2007) destacam que pais que atuam por conta própria tendem a ser um fator de inspiração, pois aspetos como independência e flexibilidade no trabalho são absorvidos em idade precoce.

Esse fator de inspiração também foi comentado por Almeida e Teixeira (2014) no estudo de caso realizado pelos referidos autores. Ainda com relação a este estudo, vale destacar que, em todos os casos analisados, ficou constatada a influência da família, dos pais e parentes (por meio de auxílio moral e financeiro) no desenvolvimento das empresas que fizeram parte do estudo.

A respeito da análise dos resultados das questões que tratam do perfil empreendedor, em um primeiro momento apresenta-se o Alfa de Cronbach, que foi a medida usada para mensurar o coeficiente de confiabilidade de escalas. Em se tratando de pesquisas exploratórias, o valor mínimo sugerido para o alfa é de 0,60 (Hair Junior, et al, 2005). Os resultados obtidos nesta análise revelaram um alfa consistente de 0,738 .

Parte-se agora para a análise das médias e o desvio padrão das respostas das questões likert. A frase que obteve a maior média foi aquela relacionada à satisfação que a atividade empreendedor pode trazer alcançando 4,26 numa escala de 1 a 5 . As menores médias foram as questões ligadas ao conhecimento dos alunos sobre os detalhes práticos exigidos para a criação de uma empresa $(2,67)$ e a frase que buscava identificar o quanto o aluno estaria disposto a assumir uma dívida de longo prazo em uma oportunidade de negócio $(3,10)$. Estas questões, inclusive, foram as que apresentaram o maior desvio padrão, sugerindo que as opiniões dos estudantes nesse quesito não estão uniformes.

\begin{tabular}{|l|c|c|}
\hline & MÉDIA & DESVIO \\
\hline Ser um empreendedor implicaria grande satisfação para mim. & 4,26 & 0,91 \\
\hline $\begin{array}{l}\text { Creio que tenho uma boa habilidade em detectar oportunidades de } \\
\text { negócio no mercado. }\end{array}$ & 3,63 & 1,05 \\
\hline $\begin{array}{l}\text { Conheço várias pessoas que poderiam me auxiliar profissionalmen- } \\
\text { te, caso eu precisasse. }\end{array}$ & 3,76 & 1,28 \\
\hline Iniciar uma empresa e mantê-la funcionando seria fácil para mim. & 2,90 & 1,11 \\
\hline $\begin{array}{l}\text { Eu conheço os detalhes práticos necessários para criar uma empre- } \\
\text { sa. }\end{array}$ & 2,67 & 1,40 \\
\hline $\begin{array}{l}\text { Nas atividades que executo, normalmente influencio a opinião de } \\
\text { outras pessoas a respeito de um determinado assunto. }\end{array}$ & 3,78 & 1,04 \\
\hline $\begin{array}{l}\text { Frequentemente as pessoas pedem minha opinião sobre os assun- } \\
\text { tos de trabalho. }\end{array}$ & 3,39 & 1,33 \\
\hline $\begin{array}{l}\text { Profissionalmente, me considero uma pessoa muito mais persisten- } \\
\text { te do que as demais. }\end{array}$ & 3,84 & 1,03 \\
\hline $\begin{array}{l}\text { No meu trabalho e/ou estudo, sempre planejo muito bem tudo o que } \\
\text { faço. }\end{array}$ & 4,09 & 0,95 \\
\hline $\begin{array}{l}\text { Eu assumiria uma dívida de longo prazo, acreditando nas vantagens } \\
\text { que uma oportunidade de negócio me traria. }\end{array}$ & 3,07 & 1,43 \\
\hline Me relaciono muito facilmente com outras pessoas. & 4,10 & 1,14 \\
\hline Tenho a firme intenção em criar uma empresa em breve. & 3,38 & 1,39 \\
\hline
\end{tabular}

Quadro 3- Média das respostas do perfil empreendedor 
Aprofundando a análise das respostas dos alunos parte-se agora para a discussão dos percentuais de concordância e discordância. Já ficou evidenciado (pela análise das médias), que a frase que obteve o maior percentual de concordância, resultante da soma entre as opções de resposta "concordo parcialmente" e "concordo totalmente", foi a relacionada com a satisfação que a atividade empreendedora poderia trazer aos estudantes (82,6\%). Vale ressaltar que esta questão obteve o segundo maior percentual de "concordo totalmente" da pesquisa, alcançando 44,5\% das respostas. Esse resultado pode indicar que os alunos ingressantes percebem os possíveis benefícios que a atividade empreendedora pode trazer, que é a satisfação pessoal, liberdade, autonomia, dentro outros aspectos constantemente referenciados na literatura e citados em relatos de vida de empreendedores.

As respostas indicaram que os alunos pesquisados têm a percepção de possuírem algumas características importantes encontradas nos empreendedores, pois as afirmativas relacionadas a estas questões alcançaram bons índices de concordância, como a capacidade de planejamento (78\% de concordância), relacionamento $(72 \%)$, de exercer influência sobre outras pessoas (69\%), de possuir uma boa rede de contatos $(68 \%)$ e de ser persistente $(65,8 \%)$.

Por outro lado, como era de esperar levando em conta o perfil da amostra, algumas afirmativas de caráter mais prático e frequentemente relacionadas ao cotidiano dos empreendedores, alcançaram índices de concordância mais baixos. Os casos mais evidentes desta constatação foram as afirmativas "Iniciar uma empresa e mantê-la funcionando seria fácil para mim" e "Eu conheço os detalhes práticos necessários para criar uma empresa", as quais alcançaram os índices mais baixos da pesquisa, 31,6\% de concordância.

Foi possível constatar também que boa parte dos alunos ainda não pensa em criar uma empresa em breve ( $40 \%$ de concordância) e se mostram reticentes em assumir uma dívida de longo prazo apostando nas vantagens que uma possível oportunidade de negócio poderia trazer (40,6\%). O quadro 4 apresenta os resultados detalhados das afirmativas e dos percentuais de discordância e concordância que foram comentados.

\begin{tabular}{|l|c|c|c|c|c|}
\hline & DT & DP & NC & CP & CT \\
\hline $\begin{array}{l}\text { Ser um empreendedor implicaria grande satisfa- } \\
\text { ção para mim. }\end{array}$ & $0 \%$ & $3,9 \%$ & $11,6 \%$ & $38,1 \%$ & $44,5 \%$ \\
\hline $\begin{array}{l}\text { Creio que tenho uma boa habilidade em detec- } \\
\text { tar oportunidades de negócio no mercado. }\end{array}$ & $3,9 \%$ & $8,4 \%$ & $26,5 \%$ & $43,2 \%$ & $16,8 \%$ \\
\hline $\begin{array}{l}\text { Conheço várias pessoas que poderiam me auxi- } \\
\text { liar profissionalmente, caso eu precisasse. }\end{array}$ & $7,1 \%$ & $8,4 \%$ & $16,1 \%$ & $32,3 \%$ & $36,1 \%$ \\
\hline $\begin{array}{l}\text { Iniciar uma empresa e mantê-la funcionando } \\
\text { seria fácil para mim. }\end{array}$ & $12,9 \%$ & $21,9 \%$ & $32,9 \%$ & $27,1 \%$ & $4,5 \%$ \\
\hline $\begin{array}{l}\text { Eu conheço os detalhes práticos necessários } \\
\text { para criar uma empresa. }\end{array}$ & $27,1 \%$ & $22,6 \%$ & $16,1 \%$ & $25,8 \%$ & $5,8 \%$ \\
\hline $\begin{array}{l}\text { Nas atividades que executo, normalmente in- } \\
\text { fluencio a opinião de outras pessoas a respeito } \\
\text { de um determinado assunto. }\end{array}$ & $3,2 \%$ & $10,3 \%$ & $17,4 \%$ & $43,2 \%$ & $25,8 \%$ \\
\hline
\end{tabular}




\begin{tabular}{|l|c|c|c|c|c|}
\hline $\begin{array}{l}\text { Frequentemente as pessoas pedem minha opi- } \\
\text { nião sobre os assuntos de trabalho. }\end{array}$ & $13,5 \%$ & $10,3 \%$ & $21,9 \%$ & $34,8 \%$ & $16,1 \%$ \\
\hline $\begin{array}{l}\text { Profissionalmente, me considero uma pessoa } \\
\text { muito mais persistente do que as demais. }\end{array}$ & $1,3 \%$ & $7,7 \%$ & $23,9 \%$ & $38,1 \%$ & $27,7 \%$ \\
\hline $\begin{array}{l}\text { No meu trabalho e/ou estudo, sempre planejo } \\
\text { muito bem tudo o que faço. }\end{array}$ & $1,3 \%$ & $6,5 \%$ & $14,2 \%$ & $37,4 \%$ & $40,6 \%$ \\
\hline $\begin{array}{l}\text { Eu assumiria uma dívida de longo prazo, acre- } \\
\text { ditando nas vantagens que uma oportunidade } \\
\text { de negócio me traria. }\end{array}$ & $16,8 \%$ & $23,9 \%$ & $17,4 \%$ & $21,3 \%$ & $18,7 \%$ \\
\hline $\begin{array}{l}\text { Me relaciono muito facilmente com outras pes- } \\
\text { soas. }\end{array}$ & $3,9 \%$ & $7,1 \%$ & $15,5 \%$ & $21,9 \%$ & $51 \%$ \\
\hline $\begin{array}{l}\text { Tenho a firme intenção em criar uma empresa } \\
\text { em breve. }\end{array}$ & $12,3 \%$ & $10,3 \%$ & $32,3 \%$ & $20 \%$ & $20,6 \%$ \\
\hline
\end{tabular}

Quadro 4 - Perfil empreendedor

Os alunos entrevistados esperam que no decorrer da sua vida universitária tanto o curso escolhido como o ambiente da universidade, por meio das diversas atividades ofertadas, desempenhem um papel de auxílio ao empreendedorismo e favoreçam a cultura empreendedora no corpo discente. As afirmativas relacionadas a estes indicadores foram responsáveis pelas médias mais altas e, consequentemente, pelos mais altos índices de concordância do estudo (ver quadros 5 e 6). Além disso, há certo otimismo por parte dos alunos em participar das atividades extracurriculares que a instituição pode vir a ofertar durante a realização do curso, uma vez que o índice de concordância relativo a essa afirmação foi de $83,8 \%$.

\begin{tabular}{|l|c|c|}
\hline & MÉDIA & DESVIO \\
\hline Espero que o curso de Engenharia me auxilie a empreender. & 4,41 & 0,90 \\
\hline $\begin{array}{l}\text { Espero que o ambiente da Universidade (eventos, palestras, ativi- } \\
\text { dades curriculares e extracurriculares) seja favorável ao empreen- } \\
\text { dedorismo. }\end{array}$ & 4,47 & 0,79 \\
\hline $\begin{array}{l}\text { Pretendo participar de atividades extracurriculares oferecidas pela } \\
\text { instituição (Diretório Acadêmico, Empresa Júnior, etc.). }\end{array}$ & 4,42 & 0,91 \\
\hline
\end{tabular}

Quadro 5 - Médias das expectativas em relação ao empreendedorismo na instituição

\begin{tabular}{|l|c|c|c|c|c|c|}
\hline & DT & DP & NC & CP & CT & NA \\
\hline $\begin{array}{l}\text { Espero que o curso de Engenharia me } \\
\text { auxilie a empreender. }\end{array}$ & $0 \%$ & $3,9 \%$ & $10,3 \%$ & $23,2 \%$ & $62,6 \%$ & $0 \%$ \\
\hline $\begin{array}{l}\text { Espero que o ambiente da Universidade } \\
\text { (eventos, palestras, atividades curricula- } \\
\text { res e extracurriculares) seja favorável ao } \\
\text { empreendedorismo. }\end{array}$ & $0 \%$ & $1,9 \%$ & $6,5 \%$ & $31 \%$ & $60,6 \%$ & $0 \%$ \\
\hline $\begin{array}{l}\text { Pretendo participar de atividades extra- } \\
\text { curriculares oferecidas pela instituição } \\
\text { (Diretório Acadêmico, Empresa Júnior, } \\
\text { etc.). }\end{array}$ & $0,6 \%$ & $5,2 \%$ & $9,7 \%$ & $20,6 \%$ & $63,2 \%$ & $0,6 \%$ \\
\hline
\end{tabular}

Quadro 6 - Expectativas em relação ao empreendedorismo na instituição 


\section{CONCLUSÃO}

O estudo teve por objetivo identificar e discutir o perfil e o potencial empreendedor de alunos ingressantes de uma instituição federal. Os resultados apontaram que uma quantidade significativa da amostra pesquisada possui alguém da família envolvido em atividades empreendedoras e isso é um fator que pode influenciar positivamente os alunos na opção em seguir o caminho de empreender um negócio próprio. A amostra pesquisada acredita que esse caminho possa ser satisfatório, entretanto, dada a pouca experiência em gestão de empresas e no mundo dos negócios, a maior parte acredita que ainda não é o momento certo para se pensar nisso.

Percebeu-se que os alunos possuem um alto grau de expectativa do curso e da instituição no que diz respeito ao inventivo à prática de empreender. Esse dado revela a responsabilidade que os dirigentes da instituição possuem em atender a essas expectativas por meio da realização das mais diversas atividades que cercam o tema empreendedorismo.

Vale observar também que esse alto nível de expectativa pode estar relacionado com a necessidade que os alunos têm e desejam em preencher com as questões práticas que envolvem a gestão de uma empresa que eles ainda não dominam.

As limitações do estudo, como a escolha do instrumento de pesquisa e do método de seleção da amostra, por exemplo, fazem com que os resultados não possam ser generalizados. Como proposta para estudos futuros sugere-se a realização de pesquisas similares em outros contextos (estudantes de instituições particulares e de outros cursos de graduação), na tentativa de se observar possíveis diferenças de perfil e do potencial empreendedor.

\section{REFERÊNCIAS}

Almeida K., Souza Neto, S.P., Nunes, A.Q., Sttefanello, M. (2008). A influência do ensino do empreendedorismo no potencial empreendedor do aluno. Revista de Negócios, 13 (2), 67-76.

Almeida, F. S., \& Teixeira, R. M. (2014). Influência da família e das redes sociais na criação de negócios por jovens empreendedores. Pretexto, 15(2), 110-128.

Araújo, L.M.B. Intenção empreendedora dos alunos de graduação em Administração da UnB: Como a trajetória os afeta? Monografia (bacharelado), Departamento de Administração, Universidade de Brasília, Brasília, DF, Brasil.

Athayde, M., Martins, G. A. (2012). Educação Empreendedora em Contabilidade. Revista Brasileira de Contabilidade, 7(193), 41-64.

Bohnenberger, M.C., Schimdt, S., Freitas, E.C. (2007). A influência da família na formação empreendedora, Anais do XXXI Encontro da Anpad, Rio de Janeiro, RJ, Brasil.

Daft, R. L. (2010). Administração. São Paulo: Cengage Learning.

Dias, T.R.F.V., Souza Neto, S.P., Boas, A.A.V. (2010). Características comportamentais 
empreendedoras relevantes: estudo de caso dos ganhadores do prêmio TOP empresarial 2007. Anais do VI Encontro de Estudos sobre Empreendedorismo e Gestão de Pequenas Empresas, Recife, PE, Brasil.

Dolabela, F. (2008). Oficina do empreendedor. São Paulo: Ed. de Cultura.

Dornelas, J.C.A. (2008). Empreendedorismo: transformando ideias em negócios. Rio de Janeiro: Elsevier.

Fernandes, C.M., Moreira, M.A., Pereira, J.V. (2015). Avaliação do potencial empreendedor de estudantes de ciências contábeis. Anais do XVIII Seminários de Administração, São Paulo, SP, Brasil. Filion, L. J. (1999). Empreendedorismo: empreendedores e proprietários-gerentes de pequenos negócios. Revista de Administração, 34 (2), 05-28.

Freitas, Oliveira, M., Saccol, A.Z., Moscarola, J. (2000). O método de pesquisa survey. Revista de Administração da USP, 35 (3), 105-112

Gomes, A. F. (2005). O empreendedorismo como uma alavanca para o desenvolvimento local. Revista eletrônica de Administração, Bahia, 4 (2).

Hair Junior; J. F., Babin, B.,Money, A. H.; Samouel, P. (2005). Fundamentos de métodos de pesquisa em administração. Porto Alegre: Bookman.

Hecke, A.P. (2011). A Intenção empreendedora dos alunos concluintes dos cursos de graduação em administração e ciências contábeis das instituições de ensino superior de Curitiba-PR. 2011. $81 f$. Dissertação de mestrado, Universidade Federal do Paraná, Curitiba, PR, Brasil.

Hisrich, R., Peters, M.,Shepherd, Dean A. (2009). Empreendedorismo.7 $7^{\mathrm{a}}$ ed. Porto Alegre: Bookman.

lizuka, E. S., \& Moraes, G. H. S. M. (2014). Análise do potencial e perfil empreendedor do estudante de Administração e o ambiente universitário: reflexões para instituições de ensino. Administração: Ensino e Pesquisa, São Paulo, 15 (3), 593-593.

Malhotra, N. K. (2006). Pesquisa de marketing: uma orientação aplicada. 4 ed. São Paulo: Bookman.

Masiero, G. (2007). Administração de empresas. São Paulo: Saraiva.

Rocha, E. L. C., \& Freitas, A. A. F. (2014). Avaliação do ensino de empreendedorismo entre estudantes universitários por meio do perfil empreendedor. Revista de Administração Contemporânea, 18(4), 465-486.

Santos, E. M. S., Pilatti, L. A., Vlastuin, J. (2005). O papel das universidades na formação do engenheiro de produção empreendedor. Anais do Encontro Nacional de Engenharia de Produção, Porto Alegre, RS, Brasil.

Santos, P.C.F. (2008). Uma escala para identificar potencial empreendedor. Tese de Doutorado Universidade Federal de Santa Catarina, Florianópolis, SC, Brasil.

Schmidt, S.; Bohnenberger, M. C. (2009). Perfil empreendedor e desempenho organizacional. RAC,13 (3), 450467.

Silva, T.; Pereira, M. F., Costa, A. M., Hinterlang, C. (2013) Metodologia em voga no campo de empreendedorismo: emprego de métodos quantitativos para o estudo das características inerentes aos empreendedores. Revista Ibero-Americana de Estratégia, 12 (4), 181-209.

Veiga, H.M.S., \& Parreira, S.M. (2015) Perfil empreendedor: análise de suas relações com valores relativos ao trabalho e auto eficácia para criar. Revista Gestão Organizacional, 8 (3). 


\section{O RELATO DE CERTEAU: QUE FERRAMENTA É ESSA?}

Data de aceite: 11/03/2020

\section{Adriana Bastos Da Costa Franciely Chropacz Rafael Carvalho Machado}

Em sua principal obra, Certeau(1994) propõe explicar práticas cotidianas por meio da criação realizada por cada indivíduo no seu dia-a-dia. Rica na descrição do papel do consumo como atividade de criação e não como atividade passiva, ele trata das práticas cotidianas realizadas pelo homem ordinário. Certeau vê nas maneiras de fazer e falar uma maneira de investigar o cotidiano. Tratando do lugar onde ocorrem os fatos linguísticos do cotidiano, sua teoria reposiciona a pesquisa social na linguagem ordinária.

Apesar dessa orientação epistemológica, não há clareza nos procedimentos de análise desses relatos. Tomar a oralidade e o relato como meio de compreender as práticas cotidianas nos causou a curiosidade de entendê-los como técnica de pesquisa, o que motivou a escrita deste resumo estendido. O objetivo é entender a natureza do relato em sua dimensão ontoepistemológica.

A teoria de Certeau descreve a vida que passa e vai acontecendo, sem acumular evidências, um "patchwork do cotidiano" composto por uma proliferação de histórias. Já discutimos em outro momento como a teoria proposta por Certeau tem contribuído para os estudos organizacionais. Identificamos três formas importantes: ampliando o alcance deles, ao dar voz a organizações e indivíduos deixados de lado pelos estudos do campo; criando uma estrutura analítica para compreensão de fenômenos de mudança; e contribuindo para a compreensão das práticas sociais em relação a dominação de uma ordem social (MACHADO; CHROPACZ; BULGACOV, 2019). Acreditamos, contudo, que a utilização da epistemologia de Certeau ainda não compreende profundamente alguns conceitos propostos pelo filósofo, especialmente a natureza e a forma de análise do relato. Não nos propomos a apresentar uma explicação definitiva, mas construímos uma hipótese de que o relato é uma narrativa resistindo a um discurso social dominante.

Para tanto, nosso primeiro passo é entender o que é o relato proposto por Certeau. Em seguida, refletimos sobre a natureza ontológica do homem narrador, para, então, finalmente relacionar o relato com o discurso.

\section{O RELATO DE CERTEAU}

Como cientista das práticas cotidianas, 
Certeau (1994) investiga táticas que são empregadas pelos homens ordinários em seu consumo. Por táticas ele entende "um cálculo que não pode contar com um próprio, nem portanto com uma fronteira que distingue o outro como totalidade invisível" ( $p$. 45). Elas dependem de uma ocasião (p. 46) e são calculadas (p. 94) conforme as ocorrências vão se sucedendo. O homem que as executa é ordinário: o consumidor da cultura social, usuário por ela dominados e que cria para tornar essa cultura inteligível e palatável. Isto revela que, embora dominados, os consumidores não podem ser confundidos com indivíduos passíveis ou dóceis (p. 39 e 90).

A identificação e estudo dessas táticas cotidianas, no entanto, não é simples. Enquanto as estratégias - outro modo de ação descrito por Certeau - são realizadas em espaços claros, com resultados acumulados, visíveis e permanentes, as táticas são ações que "só tem por lugar o do outro" e vigiando para "captar no voo" possibilidades de ganho (p. 45). Elas são invisíveis, dependentes das ocasiões que se prestam a sua ocorrência.

Em busca de uma forma de investigar essas táticas, Certeau propõe que as maneiras de falar permitem conhecer as maneiras de fazer do cotidiano. A oralidade, deixada de lado do discurso científico, deve ser repensada para a ciência social.

O estudo da linguagem ordinária faz mudar o campo de pesquisa, que sai dos ambientes institucionais e vai para a linguagem ordinária. Nessa perspectiva, linguagem deve ser entendida como "um conjunto de práticas onde a própria pessoa do analisador se acha implicada e pelas quais a prosa do mundo opera" (p. 68). Ela dá dimensão à vida, ao cotidiano.

A narrativização das práticas é apresentada como uma maneira de fazer textual, com procedimentos e táticas próprias. "Se se afirma que essa 'arte' só pode ser praticada e fora de seu exercício não se dá enunciado, a linguagem deve ser então a sua prática. (...) se a própria arte de dizer é uma arte de fazer e uma arte de pensar, pode ser ao mesmo tempo a prática e a teoria dessa arte" (p. 68). O relato instaura uma caminhada, permite ir através. É pelo relato das vítimas que a polícia instaura um inquérito policial e apura o crime. Ele cria um movimento. O relato do homem cotidiano é a tática em frente ao pesquisador.

Aqui está a contribuição de Certeau para a compreensão das práticas. Sua teoria identifica um espaço de criação fértil para o estudo desse tipo de comportamento que não deixa rastros: a oralidade é um espaço que materializa a tática. Falar é um espaço que permite que se crie e, portanto, uma ocasião para o desenrolar tático. Assim, Certeau vê o relato como uma epistemologia adequada para a compreensão das práticas sociais.

A expressão falada cotidianamente inclui figuras de linguagem, como a sinédoque e o assíndeto (CERTEAU, 1994, p. 167). São duas figuras de linguagem - o emprego parcial do significado de uma palavra ou supressão de termos de ligação - que apontam manifestações do inconsciente, longe de sugerir uma análise estrutural da oralidade, refletem simbologias que traduzem as maneiras de falar e fazer, enquanto ampliam os 
processos comunicativos dos consumidores.

Falar é "o processo indefinido de estar ausente e à procura de um próprio [espaço]" (p. 170). É uma luta de significados que ocorre numa areia movediça em que as palavras vão sofrendo um desgaste ao longo do tempo, adaptando-se às movimentações sociais, ao reemprego estabelecido. A narração é resistência a ordem social, mas que dela não escapa. São táticas, que não pretendem acumular espaço (GOUVEIA; ICHIKAWA, 2015), mas apenas tornar o mundo mais palatável.

Sua posição epistemológica aproxima-se do construcionismo (SILVA; CARRIERI; SOUZA, 2012), concepção na qual o mundo é construído pela rede de sentidos que os indivíduos dão a ele. Essa interpretação rompe com uma racionalidade de um mundo dado e objetivo, em prol de um mundo construído pela experiência dos indivíduos, evidente no relato do homem ordinário narrador que o cria. Mas qual a natureza do homem que narra? Para explorar essas questões, a seção seguinte trata do paradigma do homem narrador como ontologia do social.

\section{O HOMEM NARRADOR}

Homens são contadores de histórias e tomam decisões baseados em "boas razões”, não em verdades. O mundo do homem narrador é um conjunto de histórias, das quais devemos escolher aquelas que acreditamos num processo contínuo de recriação (FISCHER, 1987).

A racionalidade científica, subjacente a epistemologia tradicional da ciência, não concordaria com essa afirmação. Ela parte do princípio que a realidade humana é constituída por entidades discretas e distintas. Nela, a lógica de ação é determinada pela relação entre sujeito e objeto (SANDBERG, TSOUKAS, 2011). Essa concepção não deixa espaço para a realidade subjetiva construída pelo homem narrativo e para as histórias que se contam, pois interessa descobrir quais são as entidades do mundo.

A reflexão proposta por Czarniawska (2004) aponta um ponto frágil dessa concepção: embora a ciência despreze a retórica como modo de conhecimento, ela própria depende de narrativas para legitimação. A narração organiza a experiência humana - assumindo a intencionalidade da ação humana - que é, portanto, experiência retórica, fundamental para a construção do conhecimento social (FISCHER, 1987). Daí o interesse na análise de narrativas para as ciências sociais e humanas (BAKHTIN, 1981; GREIMAS, 1987; PROPP, 1968; RICOEUR, 1983).

Entendemos experiência retórica como uma transação simbólica e sobre a realidade social. Esta experiência é produtora do conhecimento social, ou seja, "concepções de relações simbólicas entre problemas, pessoas, interesses e ações, que implicam (quando aceitas) certas noções de comportamento público preferível" (FISCHER, 1987, p. 16). A retórica é mais que uma concepção epistemológica, mas uma experiência fundamentalmente ontológica. A narração e seus enredos criam e reproduzem o mundo social. 
A retórica do homem narrador não deve ser vista como uma forma de discurso em seu sentido filosófico, mas como uma função simbólica de indução do significado: "onde quer que haja persuasão, há retórica, e onde quer que haja significado há persuasão" (FISCHER, 1987, p.18). No mesmo sentido, Bruner (1991) ressalta o papel da narratividade na construção da realidade social, pois "o desenvolvimento do conhecimento da 'realidade' (...) não é nem unilinear, estritamente derivacional num sentido lógico, nem ocorre, como se pensava, 'a partir de uma tábula rasa'” (p. 2). 0 próprio conhecimento científico que tenta se diferenciar do conhecimento narrativo (CZARNIAWSKA, 1995) depende dele para se legitimar e paga a narratividade com uma moeda muito baixa por esse papel (CZARNIAWSKA, 2004), atribuindo a retórica a um conhecimento de "pensadores mal treinados" (FISCHER, 1987).

Nesse contexto, Fischer propõe um paradigma de homem alternativo às concepções de homo faber, homo economicus, homo politicus e homo sociolocus, entre tantas metáforas da realidade humana desenvolvidas: o homo narrans. Esse paradigma não vê o homem como "atores desempenhando funções restringidas ou determinadas por scripts fornecidos por instituições", mas "como contadores de histórias, autores e coautores que criativamente leem e avaliam os textos da vida" (FISCHER, 1987, p. 23). Os homens são animais que usam símbolos, criados e transmitidos através da conversa e das histórias. O paradigma do homo narrans, é coerente com a visão de Heidegger de que o homem é a conversação, que dá suporte para sua existência (FISCHER, 1987, p. 63). Nele, é a identificação que explicar como as pessoas adotam histórias. A racionalidade é narrativa, uma "lógica" intrínseca à própria ideia de narratividade. Os princípios de coerência e fidelidade são os pontos essenciais da ação humana.

Podemos resumir a lógica do paradigma narrativo a um homem contador de histórias em essência, as quais criam "boas razões" para a ação humana, conforme as situações da experiência. As "boas razões" são resultados de questões da história, biografia, cultura e caráter. A concepção de racionalidade do paradigma narrativo é determinada pela natureza das pessoas: a coerência da história, aliada ao hábito constante de testar a fidelidade narrativa, independentemente de as histórias que eles experimentam serem verdadeiras. Dessa forma, o mundo é um conjunto de histórias que devem ser escolhidas entre nós para vivermos vida em um processo de recriação contínua (FISCHER, 1987, p. 64).

Com esta lógica de ação, Fischer apresenta uma possível resposta para a pergunta "o que acontece quando algo é escrito ou dito?" (FISCHER, 1987, p. 6). Enquanto sua resposta é que há a criação de um mundo de histórias pelo homem, Certeau vê com mais detalhe a arte de falar: o binômio escrita/leitura é a produção/ consumo desse mundo em que o homem é narrador. Para Certeau (1994), a escolha das histórias vividas é um processo de disputa por credibilidade, em que a citação é "a arma absoluta do fazer crer. (...) Citar o outro a seu favor é portanto dar credibilidade aos simulacros produzidos num lugar particular" (p. 263). O relato não é apenas uma 
criação autônoma de mundo do indivíduo que vive, mas um processo de persuasão constante, uma disputa pela verdade narrativa. A racionalidade científica representa claramente esse processo de legitimação de uma história, por uma espécie de "autocitação perpétua" que confere "realidade ao simulacro produzido por um poder, induzindo a crer que outros acreditem nele, mas sem fornecer nenhum objeto crível" (CERTEAU, 1994, p. 263). É nesse sentido que Certeau aponta que há um processo que converte competência em autoridade em que "reconhecido como científico, seu discurso não passava da linguagem ordinária dos jogos táticos entre poderes econômicos e autoridades simbólicas" (p. 64).

O pensamento de um homem que narra proposto por Fischer como ontologia e a concepção do relato de Certeau como epistemologia nos parecem então complementares. Contudo, destacamos uma diferença importante: enquanto aquele entende o impulso narrativo em suas formas orais e escritas, este se preocupa com o relato oral, uma vez que é essa a ocasião que revela a tática. Entendemos que o homem contador de histórias o faz de forma escrita e oral, mas é nessa última forma de narratividade que se permite a resistência a uma ordem social dominante. $O$ homem narrador não é livre em suas escolhas de histórias vividas. Onde, então, estão os limites de sua oralidade? Para explorar essa questão, a seção a seguir trata do espaço onde que se constrói a narrativa: o discurso.

\section{O DISCURSO E O DOMÍNIO SOBRE A ORALIDADE}

Cientes da longa discussão da polissemia do termo "discurso" (LARA, VIZEU, 2019) pretende-se, discutir o domínio sobre a oralidade, não definir o que é o discurso. O próprio Certeau nos dá uma pista do que domina a oralidade ao criticar Foucault: Foucault teoriza sobre os mecanismos de dominação da ordem social e Certeau afirma que sua teoria deixa escapar a resistência com o argumento de que se há dominação deve haver resistência. Se não houvesse, não seria necessário o dispositivo de dominação (CERTEAU, 1994).

O discurso é também uma construção social (FOUCAULT, 1970). Seu foco, contudo é voltado para o poder gerado pelo discurso, que "não é simplesmente aquilo que traduz as lutas ou os sistemas de dominação, mas aquilo por que, pelo que se luta, o poder do qual nos queremos apoderar" (p.10). E ainda reforça este conceito dizendo, "suponho que em toda sociedade a produção do discurso é ao mesmo tempo controlada, selecionada, organizada e redistribuída por certo número de procedimentos que têm por função conjurar seus poderes e perigos, dominar seu acontecimento aleatório, esquivar sua pesada e temível materialidade” (p.8). No mesmo sentido, Fairclough (2001) toma “o termo 'discurso' (...) como forma de prática social e não como atividade puramente individual ou reflexo de variáveis situacionais" (p.90). É uma construção social que busca o poder.

O discurso, no paradigma narrativo, é um tipo peculiar de história pois ele "é 
uma prática, não apenas de representação do mundo, mas de significação do mundo, constituindo o mundo em significado" (FAIRCLOUGH, 2001, p.91). Tanto a narrativa quanto o discurso tem papel de representar a realidade e lhe dar sentido do tempo passado e do presente da comunidade (SILVA, 2007). Ele pode ser citado, no sentido que Certeau apresenta do termo, pois "o discurso contribui para a construção de sistemas de conhecimento e crença" (FAIRCLOUGH, 2001, p.91). Isso se aproxima do que Certeau chamaria de "arte de moldar percursos" (CERTEAU, 1994, p. 166), pois as falas determinam trajetórias ou se adaptam conforme os jogos vão sendo realizados nesta partida. Há uma diferença de natureza entre esses dois tipos de história: o relato e o discurso.

\section{CONCLUSÕES}

Relato não pode ser confundido com discurso, uma vez que nossa reflexão nos leva a compreender discurso como uma espécie de história privilegiada na experiência narrativa de um homem narrativo. $O$ discurso parece ser uma instância de narração diferente do relato, pois ele organiza um sistema de conhecimento e de crenças.

Nossa hipótese é de que discurso, tal como proposto por Foucault (1970) é um campo de sentido dentro do qual se produz o relato. Assim, o relato é uma resistência à ordem discursiva, de forma que a tática da maneira de fazer fica evidente pela escolha do encadeamento de palavras e da cronologia da narrativa. De fato, tanto as análises estruturalistas quanto pós-estruturalistas consideram que a narrativa tem entre suas características a diacronicidade de eventos (BRUNER, 1991; CZARNIAWSKA, 1995; BOJE, 2001; VAARA, SONENSHEIN, BOJE, 2016). Sustenta a nossa hipótese uma contra-argumentação idêntica à crítica de Certeau à Foucault: de nada adianta a resistência das táticas sem a dominação de um discurso.

Longe de concluir que é o discurso que domina a narração, apresentamos uma hipótese a ser discutida. Se o discurso é uma construção social que traz em si poder e dominação, podemos entender o relato como forma de resistência dos dominados? A contribuição deste trabalho está na discussão da relação do relato com o discurso, buscando esclarecer termos que por vezes se confundem nos estudos organizacionais. Compreender melhor o que é o relato de Certeau na observação de práticas invisíveis realizadas pelos consumidores pode esclarecer como a oralidade pode contribuir para os estudos organizacionais, especialmente os baseados em práticas.

\section{REFERÊNCIAS}

BAKHTIN, M. (1981). The dialogic imagination. Four essays by MM Bakhtin. Austin, TX: University of Texas Press.

BOJE, D. M. Narrative Methods for Organizational \& Communication Research. London: Sage Publications, 2001. 
BRUNER, J. A construção narrativa da Realidade. Critical Inquiry, v. 18, n. 1, p. 1-21, 1991.

CERTEAU, M. De. A invenção do cotidiano: artes de fazer. 17a ed. Petrópolis: Editora Vozes, 1994.

CZARNIAWSKA, B. Narration or Science? Collapsing the Division in Organization Studies.

Organization Studies, v. 2, n. 1, p. 11-33, 1995.

CZARNIAWSKA, B. A Narrative Approach to Organization Studies. Thousand Oaks: Sage

Publications, 1998.

CZARNIAWSKA, B. Narratives in Social Science Research. 2004.

FAIRCLOUGH, N. Discurso e Mudança Social. 2001. Editora UnB.

FISHER, W. R. Human Communication as narration: Toward a Philosophy od Reason, alue and Action. Columbia: University of South Carolina, 1987.

FOUCAULT, M. A Ordem do Discurso. 1970. Edições Loyola.

GREIMAS, A. (1987). On meaning. Minneapolis: University of Minnesota Press.

GOUVÊA, J. B.; ICHIKAWA, E. Y. Alienação E Resistência : Um Estudo Sobre O Cotidiano

Cooperativo Em Uma Do Paraná. Revista Gestão \& Conexões, v. 4, n. 1, p.68-90, 2015.

LARA, L. G. A. DE; VIZEU, F. Mas Afinal, O Que É um "Discurso" em Uma Análise? Reflexões sobre análises de discurso críticas no campo de estudos organizacionais. EnEO. Anais... . p.10, 2019.

Fortaleza.

MACHADO, R. C.; CHROPACZ, F.; BULGACOV, Y. L. M. Epistemologia de Certeau e sua contribuição para os estudos baseados em práticas. EnEO. Anais... . p. 10, 2019. Fortaleza.

RICOEUR, P. (1983). Time and narrative. Trans. K McLaughlin and D. Pellauer. Chicago: University of Chicago Press.

PROPP, V. (1968). Morphology of the folktale. Austin: University of Texas Press.

OLIVEIRA, M. A notícia como narrativa e discurso. Estudos em Jornalismo e Mídia, p. 1-16, 2007.

SILVA, A. R. L. DA; CARRIERI, A. DE P.; SOUZA, E. M. DE. A constructionist approach for the study of strategy as social practice. BAR - Brazilian Administration Review, v. 9, Special Issue, p. 1-18, 2012.

VAARA, E.; SONENSHEIN, S.; BOJE, D. Narratives as Sources of Stability and Change in Organizations: Approaches and Directions for Future Research. Academy of Management Annals, jan/2016. Routledge. 


\section{CAPÍTULO 6}

\section{A RELAÇÃO ENTRE INOVAÇÃO FRUGAL E SUSTENTABILIDADE: REVISÃO DE LITERATURA NA PERSPECTIVA DO TRIPLE BOTTOM LINE}

\section{Andriele Pinto de Amorim Centro Universitário Leonardo da Vinci}

RESUMO: A relação entre inovação frugal e sustentabilidade tem sido apresentada nos estudos acadêmicos. Nessa perspectiva, este estudo trata-se de uma revisão bibliográfica de artigos provenientes do Portal da Capes no período de 2007 a 2017. O critério de seleção dos artigos foi a existência das palavraschaves "frugal innovation" e "sustainability" nos estudos. O objetivo era entender se os estudos contemplam a perspectiva do Triple Bottom Line (TBL). Vinte artigos foram revisados e foi concluído que os estudos contemplam a dimensão ambiental, social e econômica da sustentabilidade, existindo estudos que fazem uma relação multidimensional, apontando que a integração dessas dimensões tem potencial de contribuir com a sustentabilidade global, principalmente através do empreendedorismo na base da pirâmide. Nota-se, porém, que a literatura carece de estudos que aprofundem a temática investigada no campo da gestão.
THE RELATIONSHIP BETWEEN FRUGAL INNOVATION AND SUSTAINABILITY: LITERATURE REVIEW ON THE TRIPLE BOTTOM LINE PERSPECTIVE

ABSTRACT: The relationship between frugal innovation and sustainability has been presented in academic studies. In this perspective, this study is a bibliographic review of articles from the Portal da Capes from 2007 to 2017. The criteria for selecting the articles was the existence of the keywords "frugal innovation" and "sustainability" in the studies. The objective was to understand whether the studies contemplate the Triple Bottom Line (TBL) perspective. Twenty articles were reviewed and it was concluded that, in general, the studies contemplate the environmental, social and economic dimensions of sustainability, with studies that make a multidimensional relationship, pointing out that the integration of these dimensions has the potential to contribute to global sustainability, mainly through entrepreneurship. at the base of the pyramid, however. It is noted that the literature lacks studies that deepen the theme investigated in the field of management.

KEYWORDS: Sustainability; Frugal innovation; Triple Bottom Line
PALAVRAS-CHAVE: Inovação frugal; Triple Bottom Line. 


\section{I INTRODUÇÃO}

A relação entre inovação e sustentabilidade é conhecida, estabelecendo a importância do tripé ambiental, social e econômico como fator chave para que organizações se tornem organizações inovadoras sustentáveis (BARBIERI et al., 2010). O grande desafio da atualidade é produzir sem poluir, para tanto, multiplicamse esforços por criar novos produtos e programar novos processos que reduzam o impacto ambiental da atividade humana (AMATO-NETO, 2011).

Embora a consciência de que o desenvolvimento precisa contemplar um equilíbrio entre as dimensões econômica, social e ambiental, os princípios da sustentabilidade ainda são difíceis de perseguir nos países de renda baixa ou média. Argumentando-se que muito da produção atual que se utiliza de práticas sustentáveis possui um custo que muitas vezes os consumidores não poderiam arcar, justificar-se-ia a falta de um esforço inovador, pois qualquer alteração nos processos de produção poderia aumentar os custos. As regiões ou países em desenvolvimento não teriam condições de se desenvolver economicamente sem utilizarem recursos poluentes, pois não possuem nem o conhecimento científico-tecnológico e nem os recursos para os investimentos necessários, além de dificuldades na infraestrutura física, pública e privada, e humana, como ressaltado por Zeschky, Widenmayer e Gassmann (2011). É esse argumento que as inovações de baixo custo, como a frugal, visam refutar.

Com a evolução do conceito de sustentabilidade, o tripé da sustentabilidade proposto por Elkington (2001) estabelece uma relação e interdependência entre as dimensões ambiental, social e econômica, na análise dos resultados empresariais (OLIVEIRA et al., 2012). Buscar um desenvolvimento sustentável em países com poucos recursos e com necessidade sociais prementes requer o uso da inovação para vencer as barreiras do desenvolvimento.

Porém, a inovação de fronteira, com seus vultosos investimentos em $P$ \& D, nem sempre é acessível aos países em desenvolvimento. A importância da inovação frugal é proeminente dado a necessidade da adequação de produtos e serviços que sejam acessíveis no contexto de economias emergentes, o que estabelece que as soluções inovadoras cooperem na busca pela sustentabilidade global (BASU; BANERJEE; SWEENY, 2013).

Embora a literatura sobre a inovação frugal seja recente na pesquisa acadêmica, esta tem sido vista como um campo dinâmico, sendo necessário que o tema seja abordado de forma multidisciplinar e com equilíbrio (TIWARI; KALOGERAKIS, 2016). O crescente interesse nos últimos anos sobre a inovação frugal e sua relação com a sustentabilidade, conduz à problemática desse estudo que consiste em responder: os estudos acerca da relação entre a inovação frugal e sustentabilidade contemplam o tripé da sustentabilidade?

Este artigo pretende analisar se os estudos acerca da relação entre inovação frugal e sustentabilidade contemplam o tripé ambiental, social e econômico. A fim de 
atingir esse objetivo pretende-se mapear os estudos presentes no portal de teses e periódicos da Capes que tratem do tema, analisar os artigos a fim de identificar qual a dimensão da sustentabilidade é enfocado e descrever as relações que estes estabelecem com a sustentabilidade.

\subsection{Inovação e sustentabilidade: perspectivas teóricas}

Na visão de Shumpeter (1988), a inovação para ser completa deve envolver a geração de riqueza, que impacte o desenvolvimento econômico. O conceito de desenvolvimento econômico, porém, desde que o sistema tradicional de geração de riqueza começou a ser questionado tem sido repensado. Tem-se entendido por sustentabilidade, o equilíbrio entre as dimensões ambiental, social e econômica por meio do modelo proposto por Elkington (2001) conhecido como Triple Bottom Line (TBL) que vem atender a necessidade da integração de sustentabilidade à gestão das empresas.

Em termos práticos, a concepção do modelo TBL pode ser observada na construção de modelos estratégicos voltados à sustentabilidade. O modelo de criação de valor sustentável proposto por Hart e Milstein (2004) pode ser interpretado como uma forma das empresas atuarem na perspectiva do TBL. No modelo a empresa cria valor na medida em que atua simultaneamente nos quadrantes, que envolvem a redução do consumo de matéria-prima e impactos negativos, ao utilizar operações mais limpas, transparentes e responsáveis; a implantação de tecnologias direcionadas para a diminuição de agressões ambientais do homem; o atendimento a questões sociais na concepção de negócios que incluam consumidores da Base da Pirâmide, atendendo assim a necessidade de criação e distribuição de renda.

Placet, Anderson e Fowler (2005) ao definirem um modelo para a sustentabilidade ressaltaram que a contemplação do TBL nas decisões empresariais deve ter como princípio a viabilidade das soluções sustentáveis, indicando a personalização dos processos e produtos em regiões e matérias- primas que sejam específicas. Supõem que para que as empresas consigam o desenvolvimento de inovações sustentáveis, deve transpor a visão tradicional dentro e fora de sua estrutura, indo além de seus limites, formando parcerias com outras instituições de pesquisa e setores, por exemplo.

A inovação tem sido colocada como necessária para o alcance da sustentabilidade (STAUB; KAYNAK; GOK, 2016). O desenvolvimento sustentável implica mudanças no conceito tradicional de inovação, na qual se requer que a sociedade deve decidir sobre quais objetivos econômicos, sociais e ambientais devem ser atingidos, buscando assim um equilíbrio (VOLLENBROEK, 2002).

Charter (2007) entende inovação sustentável como um processo que engloba a sustentabilidade no seu sentido amplo, ou seja, abrange as suas dimensões ambiental, econômica e social e envolve desde a concepção de ideias, pesquisa e desenvolvimento até a comercialização nos sistemas empresariais. A inovação sustentável envolve produtos, serviços e tecnologias, bem como dimensionam novos 
modelos de negócios.

Dias (2014) aborda a inovação sustentável sob a ótica da sustentabilidade nas relações de produção e consumo, a chamada economia verde que consiste no investimento em ecoeficiência, que é o aumento da produtividade dos recursos utilizando-se de modificações nos ciclos e fluxos de materiais e energia. Busca-se evitar a concepção de produtos que causem impacto ambiental, em um processo que envolva tanto mudanças na tecnologia de produção quando no consumo, em um processo que vise equilibrar os efeitos da inovação entre as diferentes dimensões e partes interessadas.

Pinsky et al. (2015) ao realizarem uma revisão bibliográfica sobre o tema da inovação sustentável reconhecem o trabalho de Tidd e Bessant (2009) como um modelo que responde como a inovação pode contribuir para a sustentabilidade, seja criando novos produtos ou incrementando - os. Apontam quatro tipologias de inovações sustentáveis: 1) desenvolvimento de tecnologias alternativas em aplicações existentes; 2) evolução de novos sistemas sociais e técnicos; 3) melhoria incremental no desempenho e na qualidade de produtos e serviços existentes; e 4) criação de produtos e serviços de nicho.

No campo de pesquisa sobre a inovação, tem-se pontuado diversos tipos de inovação que tem por potencial a promoção da sustentabilidade, destacando-se além da Inovação sustentável, a inovação reversa e a inovação frugal (ROSCA; ARNOLD; BENDUL, 2016).

\subsection{Inovação frugal}

A perspectiva da inclusão do atendimento das necessidades de consumidores da Base da Pirâmide situou as empresas multinacionais no dilema geração de riqueza e inclusão social que nas palavras de Prahalad e Hart (2005) envolve "ajudar a população de baixa renda a melhorar sua qualidade de vida, produzindo e distribuindo produtos/ serviços que estejam de acordo com os padrões culturais de cada local e que sejam, ao mesmo tempo, ecologicamente sustentáveis e economicamente rentáveis." (p. 3).

Banerjee (2013) conceitua Inovação frugal como um novo paradigma que está relacionado ao contexto de mercados emergentes como a Índia. Esse tipo de inovação é considerado um dos tipos de inovação de baixo custo que tem como uma das principais características, o potencial de modificação da realidade de comunidades carentes (FERREIRA, 2015).

Radjou e Prabhu (2015) sugerem que a intensidade da inovação frugal está relacionada à ideia de fazer mais com menos, podendo ser medida pela razão entre o maior valor e os menores recursos. Ou seja, o numerador corresponde aos valores a serem entregues para os diversos stakeholders (acionistas, clientes e sociedade) e o denominador os diversos recursos (natureza, capital e tempo).

Mesmo sendo classificada como inovação de baixo custo, a inovação frugal diferencia-se por ter como meta a promoção da inclusão social por envolver a 
solução da incapacidade de compra de consumidores de mercados emergentes, seja gerando aumento de renda ou promovendo medidas que possibilitem acesso a crédito. A inovação frugal distingue-se ainda de outras inovações de baixo custo por visionar a geração da capacidade empreendedora por meio do estímulo a negócios autossustentados (BHATTI, 2012) e assim, a inovação frugal não envolve somente a economia de recursos, mas a ampliação do número de pessoas beneficiadas nesse processo (BHATTI; VENTRESCA, 2013).

A inovação frugal no âmbito dos processos das empresas tem sido relacionada a modelos de mensuração da sustentabilidade, como é o caso do TBL. Por se relacionar com princípios ecológicos, ao desenvolver produtos com baixo nível de recursos; a ampliação do acesso de consumidores a produtos e aumento de renda e promoção do empreendedorismo, possibilitando o aumento de renda de consumidores, o modelo é visto pela capacidade de analisar a sustentabilidade no processo da implantação de inovações frugais, ou seja, a sondagem dos resultados socioambientais e econômicos (BANERJEE, 2013).

\section{I PROCEDIMENTOS METODOLOGICOS}

Este estudo trata-se de um artigo de revisão bibliográfica baseada em pesquisa qualitativa e exploratória. Na primeira fase foi definida qual base de pesquisa seria utilizada para coleta dos artigos, sendo escolhida a plataforma da Coordenação de Aperfeiçoamento de Pessoal de Nível Superior (Capes) por meio do instrumento "busca por assunto".

$\mathrm{Na}$ segunda fase foram estabelecidos os critérios de busca e palavras-chaves. Utilizou-se como critério de busca, artigos publicados no período de 2007 - 2017 e revisados por pares. As palavras chaves utilizadas na busca foram "frugal innovation" e "sustainability" bem como "inovação frugal" e sustentabilidade.

$\mathrm{Na}$ terceira fase os artigos foram selecionados a partir da análise de seus resumos, sendo excluídos aqueles que não apresentavam relação entre os termos pesquisados. Observou-se que embora se tenha definido critérios, o resultado de busca apresentou artigos que apresentavam apenas um dos termos ou ainda apenas o termo "innovation".

$\mathrm{Na}$ quarta fase, os artigos selecionados passaram por uma análise de conteúdo e foram tabulados a fim de facilitar a visualização de autores, títulos, ano de publicação, fonte, bem como a quantidade de citação e tipos de pesquisas utilizadas. Interessounos, nessa fase, destacar qual a relação que os autores fazem entre a inovação frugal e sustentabilidade e como estes estão distribuídos em relação aos pilares ambiental, social e econômico, ressaltando as contribuições dos estudos. Foram encontrados 116 artigos que apresentavam correlação com as palavras-chaves "frugal innovation" e "sustainability" e selecionados 20 artigos para análise e tabulação. 


\section{I RESULTADOS}

O quadro 1 apresenta os artigos que foram selecionados para análise. Foram identificados vinte artigos que se relacionavam ao objetivo da pesquisa, tendo sido excluído os artigos que não mostraram relação entre a inovação frugal e a sustentabilidade e logo não atendiam a proposta deste estudo.

\begin{tabular}{|c|c|c|c|c|}
\hline Título & Autor (ano) & Revista & citações & Metodologia \\
\hline $\begin{array}{l}\text { Business models for sustai- } \\
\text { nable innovation - an empiri- } \\
\text { cal analysis of frugal produc- } \\
\text { ts and services }\end{array}$ & $\begin{array}{l}\text { Rosca, Eugê- } \\
\text { nia et al } \\
(2016)\end{array}$ & $\begin{array}{l}\text { Journal of cleaner } \\
\text { production }\end{array}$ & 11 & $\begin{array}{l}\text { estudo de caso } \\
\text { múltiplo }\end{array}$ \\
\hline
\end{tabular}

A perspective on frugality in Fukuda,Kaya- Journal of Technogrowing economies: trigge- no; Watanabe, logy Management ring a virtuous cycle between Chihiro for Growing Ecoconsumption propensity and nomies growth

Pesquisa teórica

\begin{tabular}{lll}
\hline Strategic directions on inno- & Christian Horn & Management Re- \\
vation management - a con- & ;Alexander & search Review \\
ceptual framework & Brem &
\end{tabular}
ceptual framework

\begin{tabular}{|c|c|c|}
\hline $\begin{array}{l}\text { Framing resource-constrai- } \\
\text { ned innovation at the 'bottom } \\
\text { of the pyramid': Insights from }\end{array}$ & Pansera, Mario & $\begin{array}{l}\text { Technological fo- } \\
\text { recasting \& social } \\
\text { change }\end{array}$ \\
\hline
\end{tabular}
in rural Bangladesh

$(2015)$
Estudo de caso etnográfico; observação não-participante

Resource-constrained pro- Sharma, Arun e Industrial markeduct development: Implica- Gopalkrishnan ting management tions for green marketing R. lyer (2012) and green supply chains

Revisão bibliográfica

\begin{tabular}{llccc}
\hline $\begin{array}{l}\text { Poverty, Business Strategy, Hart, } \\
\text { and Sustainable Develop- } \\
\text { ment }\end{array}$ & Stuart & $\begin{array}{c}\text { Organization \& } \\
\text { Environment }\end{array}$ & 0 & $\begin{array}{c}\text { Revisão bibliográ- } \\
\text { fica }\end{array}$ \\
\hline $\begin{array}{l}\text { Innovation and entrepreneu- Hall, Jeremy } \\
\text { rial dynamics in the Base of } \\
\text { the Pyramid }\end{array}$ & Technovation & 6 & $\begin{array}{c}\text { Revisão bibliográ- } \\
\text { fica }\end{array}$ \\
\hline $\begin{array}{l}\text { Research and development } \\
\text { from the bottom up - intro- der; Wolfram, } \\
\text { duction of terminologies for Pierre (2014) } \\
\text { new product development in } \\
\text { emerging markets }\end{array}$ & $\begin{array}{c}\text { Journal of Innova- } \\
\text { tion and Entrepre- } \\
\text { neurship }\end{array}$ & 33 & $\begin{array}{c}\text { Revisão biblio- } \\
\text { gráfica; quadro } \\
\text { teórico }\end{array}$ \\
\hline
\end{tabular}


Towards a sufficiency-driven Bocken, N.M.P. Environmental business model: Experien- : Short, S.W. Innovation and Soces and opportunities (2016) cietal Transitions

Sustainability-driven innova- Sarkar, Soumo- Technological fo-

tion at the bottom: Insights dip (2017) recasting \& social

Estudo de caso múltiplo from grassroots ecopreneurs
Husk Power Systems: Brin- ging Light to Rural India and Tapping Fortune at the Bot- Gupta, Rakesh
et al. (2013)
Asian Journal of Management Ca- ses

Estudo de caso
Grassroots innovation: A Hossain, Mok- Journal of cleaner systematic review of two de- ter (2016) cades of research

\begin{tabular}{|c|c|c|c|c|}
\hline $\begin{array}{l}\text { Sustainability Strategy in } \\
\text { Constrained Economic Ti- } \\
\text { mes }\end{array}$ & $\begin{array}{l}\text { Barnett, Mi- } \\
\text { chael (2015) }\end{array}$ & $\begin{array}{l}\text { Long range } \\
\text { planning }\end{array}$ & 12 & $\begin{array}{l}\text { Revisão bibliográ- } \\
\text { fica }\end{array}$ \\
\hline $\begin{array}{l}\text { Preference of e-Bike by Wo- } \\
\text { men in India-a Niche Market } \\
\text { for Auto Manufacturers }\end{array}$ & $\begin{array}{l}\text { Alamelu, Ra- } \\
\text { machandran } \\
\text { (2015) }\end{array}$ & $\begin{array}{l}\text { Verslas: teorija ir } \\
\text { praktika }\end{array}$ & 0 & $\begin{array}{l}\text { Pesquisa quanti- } \\
\text { tativa }\end{array}$ \\
\hline $\begin{array}{l}\text { The democratizing effects } \\
\text { of frugal innovation: Impli- } \\
\text { cations for inclusive growth } \\
\text { and state-building }\end{array}$ & $\begin{array}{l}\text { Kahle, Hanna } \\
\text { et al (2013) }\end{array}$ & $\begin{array}{c}\text { Journal of Indian } \\
\text { Business Resear- } \\
\text { ch }\end{array}$ & 18 & $\begin{array}{l}\text { Revisão bibliográ- } \\
\text { fica }\end{array}$ \\
\hline $\begin{array}{l}\text { Jugaad -From 'Making Do' } \\
\text { and 'Quick Fix' to an Innova- } \\
\text { tive, Sustainable and Low- } \\
\text {-Cost Survival Strategy at } \\
\text { the Bottom of the Pyramid }\end{array}$ & $\begin{array}{l}\text { Singh, Ramen- } \\
\text { dra e Mondal } \\
\text { (2012) }\end{array}$ & $\begin{array}{l}\text { International jour- } \\
\text { nal of rural mana- } \\
\text { gement }\end{array}$ & 17 & $\begin{array}{c}\text { Pesquisa explora- } \\
\text { tória }\end{array}$ \\
\hline $\begin{array}{l}\text { Frugality, A Positive Principle } \\
\text { to Promote Sustainable De- } \\
\text { velopment. }\end{array}$ & $\begin{array}{l}\text { Roiland, D. J } \\
\text { (2016) }\end{array}$ & $\begin{array}{l}\text { Agric Environ } \\
\text { Ethics }\end{array}$ & 0 & Estudo teórico \\
\hline $\begin{array}{l}\text { Crafting Sustainable Develo- } \\
\text { pment Solutions: Frugal } \\
\text { Innovations of Grassroots } \\
\text { Entrepreneurs }\end{array}$ & $\begin{array}{l}\text { Mario Panse- } \\
\text { ra ; Soumodip } \\
\text { Sarkar, (2016) }\end{array}$ & Sustainability & 5 & $\begin{array}{l}\text { Estudo de casos } \\
\text { múltiplos; }\end{array}$ \\
\hline $\begin{array}{l}\text { Do Frugal and Reverse In- } \\
\text { novation Foster }\end{array}$ & $\begin{array}{l}\text { A I e } x \text { a n d e r } \\
\text { Brem; }\end{array}$ & $\begin{array}{l}\text { Journal of Techno- } \\
\text { logy Management } \\
\text { for }\end{array}$ & & \\
\hline $\begin{array}{l}\text { Sustainability? Introduction } \\
\text { of a Conceptual } \\
\text { Framework }\end{array}$ & $\begin{array}{l}\text { Björn } \quad \text { Ivens } \\
(2013)\end{array}$ & $\begin{array}{l}\text { Growing Econo- } \\
\text { mies }\end{array}$ & 34 & Revisão teórica \\
\hline $\begin{array}{l}\text { Implications of Frugal Inno- } \\
\text { vations on Sustainable De- } \\
\text { velopment: Evaluating Water } \\
\text { and Energy Innovations }\end{array}$ & $\begin{array}{l}\text { Jarkko Levä- } \\
\text { nen et.al (2015) }\end{array}$ & Sustainability & 9 & Estudo teórico \\
\hline
\end{tabular}

Revisão bibliográfica production 1

1

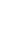


A investigação revelou 116 artigos a partir da busca da associação das palavras chaves: "frugal innovation" e "sustainability", porém apenas 20 artigos apresentavam relação com o objetivo da pesquisa que consiste em analisar se os estudos acerca da relação entre inovação frugal e sustentabilidade contemplam o tripé ambiental, social e econômico. Observou-se que a literatura que trata da inovação frugal é ainda recente sendo marcada por publicações dos últimos três anos (2015 - 2017) e que não existiam artigos com os termos pesquisados nos periódicos indexados a base da Capes.

Percebeu-se que a publicação sobre a inovação frugal e sustentabilidade inicia em 2011, com crescimento entre os anos 2015 e 2016. Comparando-se com a amostra geral, observa-se que somente três artigos resultados da busca compreendem o ano de 2010, não sendo encontrada nenhuma publicação em períodos anteriores, o que pode demonstrar que a temática da inovação frugal e sustentabilidade são recentes.

Analisou-se em relação à quantidade de autores por artigo, que tanto a produção por um único autor quanto em parceria entre até dois autores corresponde a $40 \%$ dos artigos pesquisados e em coautoria com mais de dois autores $20 \%$. Os artigos mais citados apresentam co-autoria entre dois autores.

Considerando a quantidade de trabalhos por autor, percebeu-se que somente um autor apresenta mais de um artigo, sendo reconhecida a presença da autoria de Brem Alexander, nos respectivos trabalhos: 1) Do Frugal and Reverse Innovation Foster Sustainability? Introduction of a Conceptual Framework (ALEXANDER BREM; BJÖRN IVENS, 2013); 2) Research and development from the bottom up - introduction of terminologies for new product development in emerging markets (BREM et al., 2014) e 3) Strategic directions on innovation management - a conceptual framework (CHRISTIAN HORN; ALEXANDER BREM, 2013).

Quanto à distribuição dos artigos em relação ao tipo de estudo empregado, percebeu-se a predominância de estudos qualitativos, sendo notada a presença de casos múltiplos e pesquisas bibliográficas, essa última, utilizada para o desenvolvimento de quadros teóricos.

Quanto à classificação dos autores por países, observa-se a predominância de artigos provenientes da Alemanha, Indía e Estados Unidos com 25\%, 15\% e 15\% respectivamente. Em seguida, encontra-se a Finlândia e o Canadá com 20\%. Filipinas, Singapura, Holanda, Portugal e UK obtiveram cada um, 5\% do total dos artigos analisados.

\section{I DISCUSSÃO DOS RESULTADOS}

Conclui-se que a relação entre a inovação frugal e a sustentabilidade não é conclusiva. Levãnem et al. (2015) apontam ser um problema equacionar os dois conceitos, carecendo a análise de uma abordagem pragmática. Brem e Ivens (2013) concordam que existe uma lacuna teórica sobre a temática. 
Propondo contribuir com esse gap, Levãnem et al. (2015) detectaram ainda a ausência de estudos empíricos sobre a inovação frugal nos setores de água e energia. A fim de atender a necessidade de pragmatismo nos estudos, os autores justificam que a condição que uma atividade seja considerada sustentável é a verificação de que esta promova os Objetivos do Desenvolvimento Sustentável (ODS). Porém, reconhecem que a aplicação de indicadores para mensuração da sustentabilidade, por meio da inovação frugal, pode não ser adequada a todos os setores, e a aplicação de todos os indicadores não seja possível, devendo, portanto, serem analisados aqueles que sejam mais relevantes no contexto do setor estudado.

A inovação frugal pode ser compreendida no contexto no pilar ambiental da sustentabilidade, sendo relacionada a conceitos como a ecologia e consumo consciente, nos quais se acredita que os processos que envolvem frugalidade podem gerar ganhos ambientais (BREM; PIERRE, 2014; PANSERA, 2015; ARUN, 2012). Arun (2012) pontua que o uso da inovação frugal no processo de desenvolvimento de produtos ecologicamente corretos, provoca mudanças na mentalidade tradicional de mercado que relaciona oferta de produtos ecológicos a preços altos. O marketing verde abrange no contexto da inovação frugal, benefícios à sustentabilidade e cadeia de suprimentos, gerando, além da competitividade, a inclusão de consumidores.

Dessa forma, a mentalidade frugal em modelos de negócios ao atender a necessidade de incorporação da sustentabilidade, visa além da redução de recursos, propósitos como a educação de consumidores para a redução de consumo, sendo direcionada para a oferta de produtos duráveis e que evitem a obsolescência. $\mathrm{Ou}$ seja, em vez de "promover a necessidade" esse tipo de negócio tem por objetivo a satisfação dessas (BOCKEN; SHORT, 2016). Assim, a inovação frugal é vista como uma oportunidade de negócios com potencial de provocar impactos ambientais positivos e atender à exigência da sociedade por responsabilidade socioambiental (ALAMELU; ANUSHAN; SELVABASKAR, 2015).

Singh, Gupta e Mondal (2012) discutem que esse tipo de inovação não se restringe a possibilidade de fazer mais com menos, mas visiona-a como uma metodologia que tem potencial de alternativa de sobrevivência para consumidores na base da pirâmide, focando, principalmente, no empreendedorismo como fator chave nesse contexto. Desse modo a diferenciação entre a inovação frugal e outras inovações de baixo custo fica evidenciada ao englobar o fenômeno do empreendedorismo como forma de inclusão e geração de renda (BHATTI, 2012; BHATTI; VENTRESCA, 2013), deixando clara a relação, desse tipo de inovação, com a dimensão social da sustentabilidade. O empreendedorismo na base da pirâmide é visto como um meio de alcançar os objetivos do desenvolvimento sustentável, no longo prazo, por meio da inclusão e aumento da produtividade (PANSERA; SARKAR, 2016).

Os conceitos "negócios inclusivos", "mercados de subsistência" e "empresas e pobreza" aparecem na medida em que a inovação frugal é vista como uma estratégia de negócio voltada ao alívio da pobreza e desenvolvimento sustentável. Porém, as 
pesquisas na área da Administração, ainda não avançaram no desenvolvimento de critérios para integração entre os termos e as ações empresariais (HART; SHARMA; HALME, 2016).

Tem-se observado que a formação de negócios inclusivos, seja pela formação de empreendedores na base da pirâmide ou a criação de negócios inclusivos, geram impactos positivos na economia (KAHLE; DUBIEL; PRABHU, 2016). Porém, embora a inovação frugal e economia não sejam incompatíveis, esse tipo de inovação desafia a economia ao ter como princípio a criação de projetos em que os resultados sejam ampliados para mais pessoas (ROILAND, 2016) sendo a frugalidade um incentivo para o crescimento econômico em economias emergentes (FUKUDA; WATANABE, 2011).

Reconhece-se que é possível repensar processos produtivos a partir da frugalidade e mesmo assim obter resultados econômicos enquanto gestores lidam em um contexto de escassez e mudanças de ordem ambiental e social (ROILAND, 2016). A frugalidade como inovação, pode ser praticada a fim de envolver as várias partes interessadas na cadeia de valor da empresa corroborando com a visão de Placet, Anderson e Fowler (2015) que pontuam os resultados esperados do uso da inovação como estratégia para a sustentabilidade.

Esses resultados são relacionados ao fato de que a empresa além de obter ganhos financeiros pela integração da sustentabilidade em seus processos, pode desenvolver ganhos sociais, ao pensar estrategicamente nas comunidades em seu entorno, gerando emprego e melhoria do bem estar. Internamente; podem-se obter ganhos em produtividade, fortalecimento da imagem perante seus stakeholders primários, valorizando seus colaboradores enquanto desenvolvem produtos menos agressivos ao meio ambiente.

Barnett, Darnall e Husted (2015) observaram que no contexto de retração econômica, as empresas podem aumentar investimentos em sustentabilidade. Assim, as organizações tendem a provocar mudanças nas estratégias sustentáveis por meio de inovações que as permitam fazer mais com menos recursos, aumentando, assim, a sua criação de valor, sem que necessitem realizar cortes em investimentos. A concepção da inovação, como meio de integrar as práticas das empresas à sustentabilidade, sugere que essas migrem de modelos tradicionais de produção a fim de obterem desempenho financeiro-econômico sustentável.

Com a evolução da concepção da relação entre empresas e sustentabilidade, percebe-se que as organizações são direcionadas a integrar resultados econômicos a resultados sociais e ambientais. Esse direcionamento baseia-se no modelo de Elkington (2001). Em termos da relação entre a inovação e a sustentabilidade, a integração entre as dimensões social, ambiental e econômica permitem uma análise sistêmica do impacto da inovação frugal na sustentabilidade.

Ao analisar modelos de negócios que propõem a inovação sustentável Rosca, Arnold e Bendul (2016) concluíram que empresas ou empreendedores que combinam as inovações reversas e frugais tendem a criar valor nas dimensões social, ambiental 
e econômica. Porém, embora nem sempre as empresas que adotam a inovação frugal tenham por fim de atender consumidores da Base da Pirâmide, esse público pode ser incluído.

Baseado em oito casos de ecoempreendedores da base da pirâmide da Índia, Sarkar e Pansera (2017) mostraram que ao serem direcionados pelo modelo TBL esses inovadores podem impactar o futuro da sustentabilidade global, enquanto trabalham com recursos limitados em suas comunidades.

A inovação frugal em países de economia emergentes tem indicado que a integração entre as dimensões da sustentabilidade provocam impactos no desenvolvimento sustentável no longo prazo, o que pode justificar o interesse de empresas localizadas em países desenvolvidos pelas abordagens de mercados em desenvolvimento (BREM; WOLFRAM, 2014), sobretudo, em entender como se dá a inovação em contextos em que há prevalência de recursos escassos para investimentos em inovação.

\section{I CONCLUSÃO}

O objetivo deste estudo consistiu em analisar a relação entre inovação frugal e a sustentabilidade a partir do TBL. Para isso, foi conduzida uma revisão bibliográfica a partir de artigos oriundos da base da Capes a fim de examinar as publicações do período de 2007 a 2017 . Após a busca pelas palavras-chave, 17\% dos artigos encontrados atendiam ao objetivo do trabalho, que é de analisar se os estudos acerca da relação entre inovação frugal e sustentabilidade contemplam o tripé ambiental, social e econômico.

Respondendo à questão central da investigação, a saber, se os estudos fazem uma abordagem do TBL, verificou-se que os 20 artigos selecionados contemplam a integração das dimensões ambiental, social e econômica da sustentabilidade, porém, a literatura de gestão carece de estudos que analisem o impacto dessa relação.

Os estudos que abordam a sustentabilidade ambiental por meio da inovação frugal ressaltam, principalmente, os benefícios ambientais no desenvolvimento de produtos e serviços, porém, identificou-se na base de periódicos escolhida limitado número de artigos que abordaram as evidências práticas da integração entre os dois conceitos.

A perspectiva social da relação entre os conceitos se dá no entendimento da inovação frugal como um meio de inclusão social de consumidores da base da pirâmide. A inovação frugal é vista como um meio de subsistência para empreendedores nesse contexto, porém ressalta-se a necessidade do campo da gestão de propor pesquisas que mostrem a integração entre empresas, pobreza e desenvolvimento sustentável.

Em relação à perspectiva econômica, percebeu-se que os estudos mostram que economia e inovação frugal são compatíveis, porém é necessário mudanças em 
projetos, a fim de atender à necessidade de inclusão de consumidores usando estratégias que induzam a oferta de produtos a baixo custo para clientes em contexto de escassez, de modo que a visão da sustentabilidade englobe não só a geração de lucro pela redução de recursos, mas englobe o maior número de pessoas possível.

Por fim, verificou-se que a adoção da inovação frugal provoca resultados sustentáveis na medida em que a abordagem das dimensões ambiental, social e econômica é feita de forma integrada, sobretudo, ao permitir a verificação da criação de valor sustentável e, dessa forma, o desenvolvimento de modelos estratégicos de negócios sustentáveis que utilizem a inovação como forma de repensar processos, estrutura e práticas organizacionais.

Ressalta-se como limitação desse estudo a definição da amostra que abrangeu apenas uma base de periódicos. Sugere-se para estudos posteriores, a inclusão de outras bases de pesquisa e ainda a aplicação de pesquisa empírica em países como o Brasil, a fim de analisar as contribuições da inovação frugal para a sustentabilidade.

\section{REFERÊNCIAS}

ALAMELU, R; ANUSHAN, C. S.; SELVABASKAR, S. G. PreferenCe of e-biKe by Women in india-a niChe marKet for auto manufaCturers. Verslas: teorija ir praktika, v. 1, p. 25-30, 2015.

AMATO NETO, J. (org.) Sustentabilidade e produção: teoria e prática para uma gestão sustentável. São Paulo: Atlas, 2011.

BANERJEE, P. M. The "Frugal" in Frugal Innovation. In: Evolution of Innovation Management, v. ?, p. 290-310. Palgrave Macmillan UK, 2013.

BARBIERI, J. C et al. Inovação E Sustentabilidade: Novos Modelos E Proposições/Innovation And Sustainability: New Models And Propositions/Innovación Y Sostenibilidad: Nuevos Modelos Y Proposiciones. Revista de Administração de Empresas, v. 50, n. 2, p. 146, 2010.

BARNETT, M. L.; DARNALL, N.; HUSTED, B. W. Sustainability strategy in constrained economic times. Long Range Planning, v. 48, n. 2, 63-68, 2015.

BASU, R. R.; BANERJEE, P. M.; SWEENY, E. G. Frugal innovation: core competencies to address global sustainability. Journal of Management for Global Sustainability, v. 1, n. 2, p. 63-82, 2013.

BHATTI, Y. A. What is frugal, what is innovation? Towards a theory of frugal innovation, 2012.

BHATTI, Y. A.; VENTRESCA, M. How can 'frugal innovation'be conceptualized?, 2013.

BOCKEN, N. M. P.; SHORT, S. W. Towards a sufficiency-driven business model: Experiences and opportunities. Environmental Innovation and Societal Transitions, v. 18, p. 41-61, 2016.

BREM, A.; IVENS, B. Do frugal and reverse innovation foster sustainability? Introduction of a conceptual framework. Journal of Technology Management for Growing Economies, v. 4, n. 2, p. 31- 50, 2013.

BREM, A.; WOLFRAM, P. Research and development from the bottom up-introduction of terminologies for new product development in emerging markets. Journal of Innovation and Entrepreneurship, v. 3, n. 1, 1-22, 2014. 
CHARTER, M., \& CLARK, T. Sustainable Innovation, The Centre for Sustainable Design, 2007.

OLIVEIRA, L. R et al. Sustentabilidade: da evolução dos conceitos à implementação como estratégia nas organizações. Production, v. 22, n. 1, p. 70-82, 2012.

ELKINGTON, J. Canibais com garfo e faca. São Paulo: Makron Books, 2001.

FERREIRA, V. Frugalidade, um estudo de inovações de baixo custo que modificam a realidade de comunidades carentes. In: Anais...Singep, 2015.

FUKUDA, K., \& WATANABE, C. A perspective on frugality in growing economies: triggering a virtuous cycle between consumption propensity and growth. Journal of Technology Management for Growing Economies, v. 2, n. 2, p. 79-99, 2011.

GUPTA, R. et al. Husk power systems: bringing light to rural India and tapping fortune at the bottom of the pyramid. Asian Journal of Management Cases, v. 10, n. 2, p. 129-143, 2013.

HALL, J. et. al. Entrepreneurship and innovation at the base of the pyramid: a recipe for inclusive growth or social exclusion?. Journal of Management Studies, v. 49, n. 4, p. 785-812, 2012.

HART, S. L.; MILSTEIN, M. B. Criando valor sustentável. RAE executivo, v. 3, n. 2, p. 65-79, 2004. HART, S., SHARMA, S.; HALME, M. Poverty, Business Strategy, and Sustainable Development, 2016.

HORN, C.; BREM, A. Strategic directions on innovation management - a conceptual framework. Management research review, v. 36, n. 10, p. 939-954, 2013.

HOSSAIN, M. Grassroots innovation: A systematic review of two decades of research. Journal of Cleaner Production, v. 137, p. 973-981, 2016.

LEVÄNEN, J et al. Implications of frugal innovations on sustainable development: Evaluating water and energy innovations. Sustainability, v. 8, n. 1, p. 4, 2015.

NARI KAHLE, H., The democratizing effects of frugal innovation: Implications for inclusive growth and state-building. Journal of Indian Business Research, v. 5, n. 4, p. 220-234, 2013.

PANSERA, M.; OWEN, R. Framing resource-constrained innovation at the 'bottom of the pyramid': Insights from an ethnographic case study in rural Bangladesh. Technological Forecasting and Social Change, v. 92, p. 300-311, 2015.

PANSERA, M; SARKAR, S. Crafting Sustainable Development Solutions: Frugal Innovations of Grassroots Entrepreneurs. Sustainability, v. 8, n. 1, p. 51, 2016.

PINSKY, V. C. et al. Inovação sustentável: uma perspectiva comparada da literatura internacional e nacional. Revista de Administração e Inovação, v. 12, n. 3, p. 226-250, 2015.

PLACET, M.; ANDERSON, R.; FOWLER, K. M. Strategies for sustainability. Research-Technology Management, v. 48, n. 5, p. 32-41, 2005.

PRAHALAD, C. K. A riqueza na base da pirâmide. Bookman, Porto Alegre, 2005.

ROILAND, D. Frugality, A Positive Principle to Promote Sustainable Development. Journal of Agricultural and Environmental Ethics, v. 29, n. 4, p. 571-585, 2016.

ROSCA, E.; ARNOLD, M.; BENDUL, J. C. Business models for sustainable innovation-an empirical 
analysis of frugal products and services. Journal of Cleaner Production, v. 162, 2016.

SINGH, R.; GUPTA, V.; MONDAL, A. Jugaad - From 'Making Do'and 'Quick Fix'to an innovative, sustainable and low-cost survival strategy at the bottom of the pyramid. International Journal of Rural Management, v. 8, n. 1-2, p. 87-105, 2012.

ZANANDREA, G. et al .Inovação Frugal: uma Análise Bibliométrica da Produção na Base Scopus. Ucs.br, 2015.

ZESCHKY, M.; WIDENMAYER, B.; GASSMANN, O. Frugal innovation in emerging markets. ResearchTechnology Management, v. 54, n. 4, p. 38-45, 2011. 


\section{ASPECTOS INTRÍNSECOS A SEREM CONSIDERADOS NO RELATÓRIO FINAL DE AUDITORIA INDEPENDENTE DA INFORMAÇÃO CONTÁBIL HISTÓRICA}

Data de aceite: 11/03/2020

\section{Romeu Schvarz Sobrinho}

RESUMO: Este estudo tem por objetivo apresentar estruturas formais do relatório final de Auditoria Independente da Informação Contábil Histórica, comumente denominada no Brasil de Auditoria das Demonstrações Contábeis, de acordo com elementos técnicos, estruturais e legais, delimitados às orientações previstas nas NBC TAs 700, 705 e 706, sobre o conjunto completo de demonstrações contábeis de entidade listada, elaboradas de acordo com a estrutura de apresentação adequada. A partir da contextualização são apresentadas as fases do processo de auditoria (planejamento, execução e relatórios), elementos técnicoestruturais e legais para apresentação do relatório final. Como resultado, constatouse que os Parágrafos de Opinião e Base para Opinião devem ser apresentados nesta ordem, com redações de conteúdo específico dependendo do tipo de opinião (não modificada ou modificada) e espécie (sem ressalva, com ressalva, adversa ou com abstenção de opinião) a ser expressada, enquanto que o Parágrafo de Ênfase pode ser incluído no relatório sempre que o auditor julgar importante chamar a atenção dos usuário, referente a um assunto apropriadamente apresentado ou divulgado nas demonstrações contábeis, em qualquer tipo de opinião. O Parágrafo de Outros Assuntos deve tratar de um assunto não apresentado ou não divulgado nas demonstrações contábeis. Outros parágrafos como Principais Assuntos de Auditoria, Responsabilidade da Administração e da Governança pelas Demonstrações Contábeis e Responsabilidades do Auditor pela Auditoria das Demonstrações Contábeis devem ser apresentados de acordo outras NBC TAs, por isso podem ser objetos de outros estudos.

INTRINSIC ASPECTS TO BE CONSIDERED IN THE AUDIT REPORT INDEPENDENT OF HISTORICAL ACCOUTING INFORMATION

PALAVRAS-CHAVE: auditoria, auditoria financeira, auditoria independente, relatório final, normas de auditoria.

\section{I CONTEXTO DA AUDITORIA DAS} DEMONSTRAÇÕES CONTÁBEIS NO BRASIL

A auditoria das demonstrações contábeis no Brasil segue ritmo continuado de convergência às normas internacionais de auditoria da informação contábil histórica. Diversas foram às mudanças e as 
regulamentações que impuseram novas estruturas, responsabilidades, procedimentos, técnicas e outros elementos que devem ser observados pelos profissionais que atuam nesse tipo de trabalho e/ou especialização da contabilidade.

Nesse contexto, este estudo tem por objetivo apresentar possíveis estruturas formais do relatório final de Auditoria Independente da Informação Contábil Histórica, comumente denominada no Brasil de Auditoria das Demonstrações Contábeis, de acordo com elementos técnicos, estruturais e legais, delimitados às orientações previstas nas NBC TAs 700, 705 e 706, sobre o conjunto completo de demonstrações contábeis de entidade listada, elaboradas de acordo com a estrutura de apresentação adequada. A seguir, são apresentadas seções com apresentação das fases do processo de auditoria contábil-financeira, aspectos técnicos, estruturais e legais, apresentação da estrutura formal do relatório e considerações finais.

\section{I FASES DO PROCESSO DE AUDITORIA CONTÁBIL-FINANCEIRA}

O relatório final de uma Auditoria Contábil-Financeira é resultante do processamento sequencial de três fases operacionais: planejamento, execução e relatório, conforme visualiza-se na Figura 1 - Abordagem da Auditoria numa Visão Sistêmica ou de Processo.

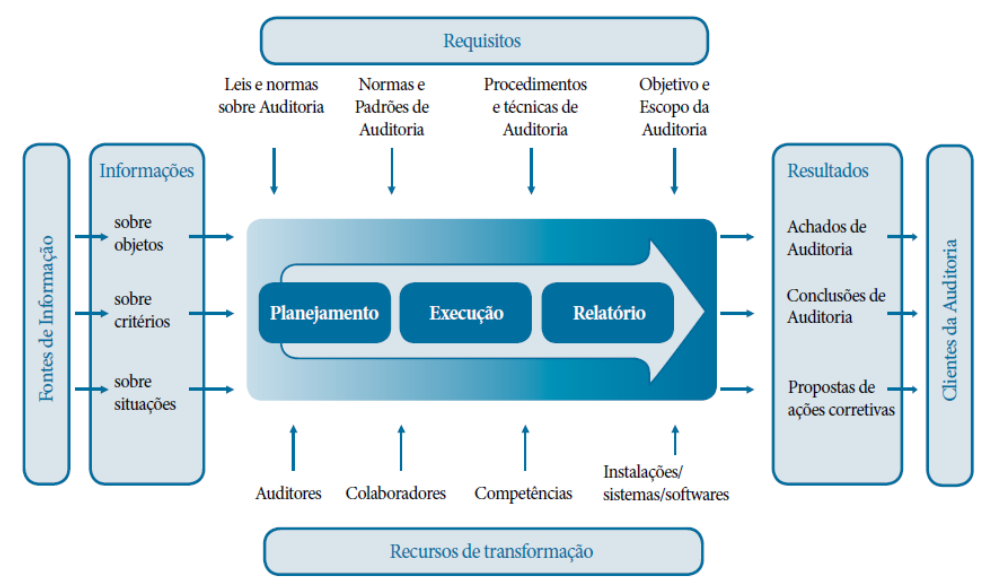

Figura 1 - Abordagem da Auditoria numa Visão Sistêmica ou de Processo Fonte: BRASIL (2011, p.56).

$\mathrm{Na}$ fase de planejamento é elaborado o programa de trabalho, além da realização de outros procedimentos como montagem da equipe, avaliação de riscos e formalização contratual. $\mathrm{Na}$ fase de execução são aplicados procedimentos e técnicas para alcance de evidências adequadas e suficientes, as quais devem ser relatadas (fase de relatório) considerando os achados de auditoria, o objeto auditado e os objetivos inicialmente propostos no programa de trabalho, elaborado na fase de planejamento, com vistas a fundamentar a opinião do auditor a ser emitida. $\mathrm{O}$ 
relatório final do auditor independente deve ser formalizado considerando estrutura determinada, principalmente, pelas Normas Brasileiras de Contabilidade Técnicas de Auditoria Independente da Informação Contábil Histórica 700, 705 e 706 (NBC TAs 700, 705 e 706), as quais impõem a consideração de aspectos técnicos, estruturais e legais quanto à redação e divulgação do relatório, conforme a seguir apresentado.

\section{I ASPECTOS TÉCNICOS, ESTRUTURAIS E LEGAIS APLICÁVEIS NO RELATÓRIO FINAL}

De acordo com a NBC TA 700, o relatório dos auditores independentes, configura-se em documento no qual o Auditor expressa sua opinião, de forma clara e objetiva, sobre as demonstrações contábeis nele indicadas. Além da expressão da opinião, o auditor deve considerar outros elementos técnicos, estruturais e legais, quando da elaboração e divulgação do relatório final, conforme apresentados nas subseções seguintes.

\subsection{Elementos Técnicos e Estruturais}

Crepaldi (2010), afirma que as técnicas de auditoria são o conjunto de investigações empregadas pelo auditor para reunir evidências. Segundo Brasil (2011, p.44), "as técnicas são as práticas, os meios ou as ferramentas utilizadas para obtenção e tratamento das informações e dos diferentes tipos de evidências que darão suporte às afirmações do auditor." Elas não são provas em si. Elas proporcionam a obtenção das provas necessárias para um auditor emitir relatório [parecer] bem fundamentado (CREPALDI, 2010), enquanto que um procedimento de auditoria é o caminho adotado pelo auditor que contribui para o alcance dos objetivos inicialmente propostos.

$\mathrm{Na}$ fase de planejamento do trabalho de auditoria, é importante para o auditor ou equipe de auditoria, inteirar-se ao máximo possível daquilo que afeta e/ou que poderá afetar o trabalho e/ou o objeto auditado, como fatos, atores, situações, complexidade do negócio, relações com partes relacionadas, mercados interno e externo, histórico dos gestores do projeto ou do programa e de diversos outros fatores. É na fase de execução que são aplicadas as técnicas e procedimentos para alcance das evidências, enquanto que na fase de relatório é redigido o documento final (relatório final), no qual deve ser expressa a opinião do auditor, de acordo com os achados de auditoria (evidências adequadas e suficientes) e tipo de opinião a ser exarada (não modificada ou modificada, dependendo da situação encontrada e avaliada pelos auditores).

Assim sendo, no relatório final de auditoria financeira, à luz das NBC TAs 700, 705 e 706, deve-se considerar, além de dos elementos técnicos estruturais, elementos normativos, conforme a seguir apresentados. 


\subsection{Elementos Normativos Aplicáveis}

As Normas Brasileiras de Contabilidade - Técnicas de Auditoria das Demonstrações Contábeis (NBC TAs) e os Comunicados Técnicos (CTAs), determinam estruturas formais para redação e apresentação do relatório final de Auditoria Independente da Informação Contábil Histórica, em termos significativamente diferentes dependendo do tipo de negócio explorado, dos achados de auditoria e, consequentemente, do tipo de opinião a ser expressada.

O conjunto normativo vigente no Brasil, em janeiro de 2020, determinado pelo Conselho Federal de Contabilidade (CFC), é representado por 37 NBC TAs + Estrutura Conceitual + 24 CTAs. Assim sendo, e por razões de delimitação do trabalho, este estudo trata especificamente das NBC TAs 700, 705 e 706, as quais dispõem, especificamente, e nesta ordem, sobre: (a) a formação da opinião e emissão do relatório do auditor independente sobre as demonstrações contábeis (NBC TA 700); modificações na opinião do auditor independente (NBC TA 705); e sobre parágrafos de ênfase e parágrafos de outros assuntos no relatório do auditor independente (NBC TA 706).

\subsubsection{Tipos de Opiniões a Serem Emitidas}

As NBC TAs 700 e 705, apresentam regras técnicas, estruturais e legais para determinação do tipo de opinião a ser exarada em parágrafo específico no relatório final.

O Parágrafo de Opinião contém a opinião expressa sobre as demonstrações contábeis e referência à estrutura de relatório financeiro aplicável utilizada para elaborar as demonstrações contábeis (práticas contábeis adotadas no Brasil ou, se for o caso, incluir a identificação de origem da estrutura de relatório financeiro aplicada).

De acordo com aquelas NBC TAs, a opinião do auditor poderá ser: (a) Não Modificada; ou (b) Modificada, dependendo dos achados de auditoria, alcançados na fase de execução do trabalho, e julgamento do auditor a ser materializado no relatório final com um tipo de opinião. Se a opinião for do tipo Não Modificada a espécie será do tipo Sem Ressalva. Se for Modificada as espécies poderão ser dos tipos: Com Ressalva, Adversa ou Com Abstenção de Opinião.

Opinião Não Modificada, conforme NBC TA 700, é a opinião expressada pelo auditor quando ele concluir que as demonstrações contábeis são elaboradas, em todos os aspectos relevantes, de acordo com a estrutura de relatório financeiro aplicável, ou seja, de acordo com a estrutura de relatório financeiro adotada pela administração e, quando apropriado, pelos responsáveis pela governança na elaboração das demonstrações contábeis, que é aceitável em vista da natureza da entidade e do objetivo das demonstrações contábeis ou que seja exigida por lei ou regulamento. Neste tipo de opinião o auditor deve expressar-se, no parágrafo de Opinião, da seguinte forma: 
(a) "em nossa opinião, as demonstrações contábeis apresentam adequadamente, em todos os aspectos relevantes,... de acordo com [a estrutura de relatório financeiro aplicável]"; ou

(b) "em nossa opinião, as demonstrações contábeis apresentam uma visão verdadeira e justa... de acordo com [a estrutura de relatório financeiro aplicável]".

O auditor deve modificar sua opinião, portanto, emitir uma opinião do tipo Modificada (Com Ressalva, Adversa ou Com Abstenção de Opinião) de acordo com a NBC TA 705, se ele: (i) concluir, com base em evidência de auditoria obtida, que as demonstrações contábeis tomadas em conjunto apresentam distorções relevantes; ou (ii) não conseguir obter evidência de auditoria apropriada e suficiente para concluir que as demonstrações contábeis tomadas em conjunto não apresentam distorções relevantes. Neste caso, o auditor deve expressar-se da seguinte forma:

1) Na espécie Com Ressalva:

(a) "as demonstrações contábeis estão apresentadas adequadamente, em todos os aspectos relevantes (ou apresentam uma visão verdadeira e justa) [...], de acordo com [a estrutura de relatório financeiro aplicável], quando o relatório é emitido de acordo com uma estrutura de apresentação adequada"; ou

(b) "as demonstrações contábeis foram elaboradas, em todos os aspectos relevantes, de acordo com [a estrutura de relatório financeiro aplicável], quando o relatório é emitido de acordo com uma estrutura de conformidade".

2) Quando o auditor expressar uma opinião Adversa, ele deve especificar que, em sua opinião, devido à relevância dos assuntos descritos no Parágrafo "Base para Opinião Adversa" que:

(a) "as demonstrações contábeis não estão apresentadas adequadamente (ou não apresentam uma visão verdadeira e justa) [...], de acordo com [a estrutura de relatório financeiro aplicável], quando o relatório é emitido de acordo com uma estrutura de apresentação adequada"; ou

(b) "as demonstrações contábeis não foram elaboradas, em todos os aspectos relevantes, de acordo com [a estrutura de relatório financeiro aplicável], quando o relatório é emitido de acordo com uma estrutura de conformidade".

3) Quando o auditor se abstém (opinião do tipo Com Abstenção de Opinião) de expressar uma opinião devido à impossibilidade de se obter evidência de auditoria apropriada e suficiente, ele deve: 
(a) especificar que ele não expressa opinião sobre as demonstrações contábeis;

(b) especificar que, devido à relevância dos assuntos descritos no parágrafo "Base para Abstenção de Opinião", o auditor não conseguiu obter evidência de auditoria apropriada e suficiente para fundamentar sua opinião de auditoria sobre as demonstrações contábeis; e

(c) alterar a declaração requerida pelo item 24(b) da NBC TA 700, que indica que as demonstrações contábeis foram auditadas, para especificar que o auditor foi contratado para auditar as demonstrações contábeis.

Além das formalidades apresentadas nas seções e subseções anteriores, os auditores devem, também, apresentar e redigir adequadamente os parágrafos: (a) "Base para Opinião"; (b) "De Ênfase"; e (c) "De Outros Assuntos".

\subsubsection{Parágrafos Base para Opinião, Ênfase e Outros Assuntos}

O Parágrafo Base para Opinião fornece contexto importante para a opinião do Auditor. Consequentemente, esta norma requer que a seção Base para Opinião venha imediatamente após a seção Opinião no relatório do auditor.

Segundo a NBC TA 700

O relatório do auditor deve incluir uma seção, logo após a seção "Opinião", com o título "Base para Opinião", que: (a) declare que a auditoria foi conduzida em conformidade com as normas de auditoria; (b) referencie a seção que descreve as responsabilidades do auditor, segundo as normas de auditoria; (c) inclua a declaração de que o auditor é independente da entidade de acordo com as exigências éticas relevantes relacionadas com a auditoria e que ele atendeu às outras responsabilidades éticas do auditor de acordo com essas exigências. A declaração deve identificar a jurisdição de origem das exigências éticas relevantes ou referir-se ao Código de Ética do International Ethics Standards Board for Accountants (IESBA) da Federação Internacional de Contadores (IFAC); e (d) declare se o auditor acredita que a evidência de auditoria obtida por ele é suficiente e apropriada para fundamentar sua opinião.

Porém, quando o auditor modificar a opinião sobre as demonstrações contábeis, ele deve:

(a) alterar o título "Base para Opinião" requerido pelo item 28 da NBC TA 700 para "Base para Opinião com Ressalva", "Base para Opinião Adversa" ou "Base para Abstenção de Opinião", conforme apropriado; e

(b) nessa seção, incluir a descrição do assunto que deu origem à modificação.

Segundo as NBC TAs 705 e 706, se o auditor considerar necessário chamar a atenção dos usuários para um assunto apresentado ou divulgado nas demonstrações contábeis que, segundo seu julgamento, é de tal importância que é fundamental para o entendimento pelos usuários das demonstrações contábeis, ele deve incluir Parágrafo de Ênfase no seu relatório.

Parágrafo de Ênfase é o parágrafo incluído no relatório do auditor referente a um assunto apropriadamente apresentado ou divulgado nas demonstrações contábeis 
que, de acordo com o julgamento do auditor, é de tal importância que é fundamental para o entendimento pelos usuários das demonstrações contábeis.

Quando o auditor incluir um Parágrafo de Ênfase no seu relatório, ele deve:

(a) incluir o parágrafo em seção separada do relatório do auditor, com título apropriado que inclua o termo "Ênfase";

(b) incluir no parágrafo uma referência clara ao assunto enfatizado e à nota explicativa que descreva de forma completa o assunto nas demonstrações contábeis. Tal parágrafo deve referir-se apenas a informações apresentadas ou divulgadas nas demonstrações contábeis; $\mathrm{e}$

(c) indicar que a opinião do auditor não se modifica no que diz respeito ao assunto enfatizado.

Dependendo da situação, faz-se necessário incluir um Parágrafo de Outros Assuntos. Este parágrafo deve tratar de um assunto não apresentado ou não divulgado nas demonstrações contábeis e que, de acordo com o julgamento do auditor, é relevante para os usuários entenderem a auditoria, as responsabilidades do auditor ou o seu relatório. Neste caso, o auditor deve incluir um parágrafo de outros assuntos no seu relatório, desde que:

(a) não seja proibido por lei ou regulamento; e

(b) quando a NBC TA 701 se aplica, o assunto não tenha sido determinado como um principal assunto de auditoria a ser comunicado no relatório do auditor.

Em termos estruturais e/ou formais para redação e apresentação do relatório final, o Parágrafo de Outros Assuntos, quando incluído pelo auditor, deve ficar em seção separada do relatório com o título Outros Assuntos ou outro título apropriado.

\section{I ANÁLISE E APRESENTAÇÃO DAS POSSÍVEIS ESTRUTURAS FORMAIS DO RELATÓRIO}

As NBC TAs 700, 705 e 706, determinam que o tipo de opinião a ser exarada no relatório e a inclusão ou não de outros parágrafos (Base para Opinião, de Ênfase ou de Outros Assuntos), impactam na estrutura formal para sua apresentação e/ou divulgação. Assim sendo, se as evidências de auditoria, alcançadas durante a fase de execução, não detectarem distorções relevantes entre as demonstrações contábeis auditadas e a estrutura de relatório financeiro exigida para aquela entidade, o tipo de opinião deve ser do tipo Não Modificada da espécie Sem Ressalva, com inclusão ou não dos parágrafos de Ênfase e de Outros Assuntos. Porém, se os achados 
de auditoria comprovarem que houve erro, fraude ou descumprimento de uma determinação legal e/ou normativa, o tipo de opinião deve ser do tipo Modificada, das espécies Com Ressalva, Adversa ou Com Abstenção de Opinião, dependendo da natureza, alcance e generalização das distorções nos dados contábeis, os quais em nível maior ou menor afetarão a tomada de decisões dos usuários. Deste modo, dependendo do tipo e espécie de opinião escolhida, o relatório final deve apresentar uma estrutura formal própria, incluindo linguagem, seções e parágrafos específicos em cada caso, conforme apresentados a seguir.

\subsection{Estrutura do Relatório com Opinião do Tipo Não Modificada da Espécie Sem} Ressalva

Ao expressar uma opinião Não Modificada, da espécie sem ressalva, sobre as demonstrações contábeis elaboradas de acordo com a estrutura de apresentação adequada, a forma de apresentação do relatório deve considerar, no mínimo, os seguintes elementos, nesta ordem:

$\checkmark$ Título: (de acordo com a NBC TA 700). Ex.

RELATÓRIO DO AUDITOR INDEPENDENTE SOBRE AS DEMONSTRAÇÕES CONTÁBEIS

$\checkmark$ Para quem o relatório é endereçado? (de acordo com a NBC TA 700). Destinatário.

conforme exigido pelas circunstâncias da contratação. Ex.:

Aos acionistas da Companhia ABC [ou outro destinatário apropriado]

$\checkmark$ Parágrafo de Opinião: (de acordo com a NBC TA 700). Ex.:

Examinamos as demonstrações contábeis da Companhia $A B C$, que compreendem o balanço patrimonial em 31 de dezembro de $20 \times 1$ e as respectivas demonstrações do resultado, do resultado abrangente, das mutações do patrimônio líquido e dos fluxos de caixa para o exercício findo nessa data, bem como as correspondentes notas explicativas, incluindo o resumo das principais políticas contábeis.

Em nossa opinião, as demonstrações contábeis acima referidas apresentam adequadamente, em todos os aspectos relevantes, a posição patrimonial e financeira da Companhia ABC em 31 de dezembro de 20X1, o desempenho de suas operações e os seus fluxos de caixa para o exercício findo nessa data, de acordo com as práticas contábeis adotadas no Brasil.

$\checkmark$ Parágrafo Base para Opinião (de acordo com a NBC TA 700). Ex. 
Nossa auditoria foi conduzida de acordo com as normas brasileiras e internacionais de auditoria. Nossas responsabilidades, em conformidade com tais normas, estão descritas na seção a seguir, intitulada "Responsabilidades do auditor pela auditoria das demonstrações contábeis". Somos independentes em relação à Companhia, de acordo com os princípios éticos relevantes previstos no Código de Ética Profissional do Contador e nas normas profissionais emitidas pelo Conselho Federal de Contabilidade, e cumprimos com as demais responsabilidades éticas de acordo com essas normas. Acreditamos que a evidência de auditoria obtida é suficiente e apropriada para fundamentar nossa opinião.

\section{$\checkmark$ Parágrafo de Ênfase}

Será incluído se o Auditor julgar importante chamar a atenção dos usuários sobre determinado assunto tratado nas demonstrações contábeis.

\section{$\checkmark$ Principais Assuntos de Auditoria}

Descrição de cada um dos principais assuntos de auditoria, de acordo com a NBC TA 701.

$\checkmark$ Parágrafo de Outros Assuntos. Este parágrafo deve tratar de um assunto não apresentado ou não divulgado nas demonstrações contábeis. São outras informações que acompanham as Demonstrações Contábeis e o Relatório do Auditor que podem ou não ser incluído no relatório. (Apresentação também de acordo com Apêndice 2 da NBC TA 720).

\section{$\checkmark$ Responsabilidade da Administração e da Governança pelas Demonstrações Contábeis}

Esta seção do relatório do auditor deve explicar a responsabilidade da administração pela:

(a) elaboração das demonstrações contábeis, de acordo com a estrutura de relatório financeiro aplicável e pelos controles internos que a administração determinar que sejam necessários para permitir a elaboração de demonstrações contábeis livres de distorção relevante, independentemente se causada por fraude ou erro; e

(b) avaliação da capacidade da entidade de manter a continuidade operacional (ver item 2 da NBC TA 570), e se o uso da base contábil de continuidade operacional é apropriado, assim como divulgar, se aplicável, questões relacionadas com a continuidade operacional. A explicação da responsabilidade da administração por essa avaliação deve incluir uma 
descrição de quando o uso da base contábil de continuidade operacional é apropriado.

\section{$\checkmark$ Responsabilidades do Auditor pela Auditoria das Demonstrações Contábeis}

Essa seção do relatório do auditor deve declarar que:

(a) os objetivos do auditor são: (i) obter segurança razoável de que as demonstrações contábeis tomadas em conjunto estão livres de distorção relevante, independentemente de se causada por fraude ou erro; e (ii) emitir um relatório que inclua a opinião do auditor, e que a segurança razoável é um alto nível de segurança, mas não é uma garantia de que uma auditoria conduzida, de acordo com as normas de auditoria sempre detectará uma distorção relevante, quando ela existir;

(b) as distorções podem decorrer de fraude ou erro, e: (i) descrever que elas são consideradas relevantes se, individualmente ou em conjunto, pudesse ser razoavelmente esperado que elas influenciassem as decisões econômicas de usuários tomadas com base nas demonstrações contábeis; ou (ii) fornecer uma definição ou descrição da materialidade de acordo com a estrutura de relatório financeiro aplicável;

(c) como parte da auditoria de acordo com as normas de auditoria, o auditor exerce o julgamento profissional e mantém o ceticismo profissional durante toda a auditoria;

(d) descrever a auditoria especificando que as responsabilidades do auditor são:

(I) identificar e avaliar os riscos de distorção relevante nas demonstrações contábeis, independentemente se causada por fraude ou erro, planejar e executar procedimentos de auditoria que respondam a esses riscos e obter evidência de auditoria que seja suficiente e apropriada para fornecer uma base para a opinião do auditor. O risco de não se detectar uma distorção relevante resultante de fraude é maior que aquele de se detectar uma distorção relevante resultante de erro, uma vez que a fraude pode envolver conluio, falsificação, omissões intencionais, falsas declarações ou transgressão dos controles internos;

(II) obter entendimento dos controles internos relevantes para a auditoria para planejar procedimentos de auditoria que são apropriados nas circunstâncias, mas não para fins de expressar uma opinião sobre a eficácia dos controles internos da entidade. Nas circunstâncias em que o auditor também tem a responsabilidade de expressar uma opinião sobre a eficácia dos controles 
internos juntamente com a auditoria das demonstrações contábeis, o auditor deve omitir a frase de que a consideração do auditor sobre os controles internos não tem a finalidade de expressar uma opinião sobre a eficácia dos controles internos da entidade;

(III) avaliar a adequação das políticas contábeis utilizadas e a razoabilidade das estimativas contábeis e das respectivas divulgações feitas pela administração;

(IV) concluir quanto à adequação do uso, pela entidade, da base contábil de continuidade operacional e, com base na evidência de auditoria obtida, se existe incerteza relevante relacionada com eventos ou condições que podem levantar dúvida significativa quanto à capacidade de continuidade da entidade. Se o auditor concluir que existe incerteza relevante, ele deve chamar atenção no seu relatório para as respectivas divulgações nas demonstrações contábeis ou, se essas divulgações forem inadequadas, modificar a opinião. As conclusões do auditor se baseiam na evidência de auditoria obtida até a data do seu relatório. Contudo, eventos ou condições futuras podem fazer com que a entidade interrompa a sua continuidade operacional;

(V) quando as demonstrações contábeis são elaboradas de acordo com uma estrutura de apresentação adequada, avaliar a apresentação geral, estrutura e conteúdo das demonstrações contábeis, incluindo as divulgações, e se elas representam as transações e eventos subjacentes de forma a alcançar a apresentação adequada.

\section{$\checkmark$ Local e data}

$\checkmark$ Nome do auditor independente (pessoa física ou jurídica)

$\checkmark$ Números de registro no $\mathrm{CRC}$ da firma de auditoria e do profissional que assina o relatório e sua categoria profissional de contador

$\checkmark$ Assinatura do auditor independente

\subsection{Estrutura do Relatório com Opinião do Tipo Modificada da Espécie Com} Ressalva

O relatório com opinião do tipo Com Ressalva é emitido quando o Auditor conclui que o efeito de qualquer inconformidade, inconsistência, discordância ou restrição na extensão de um trabalho não é de tal magnitude que requeira Opinião do tipo Adversa ou Com Abstenção de Opinião. Neste caso, o Auditor deve alterar os Parágrafos de Opinião e Base para Opinião em relação ao padrão apresentado neste trabalho, na subseção anterior 4.1 - Estrutura de relatório com opinião do tipo Não Modificada, da 
espécie Sem Ressalva, incluindo ou não Parágrafo de Ênfase, mantendo a redação dos demais aspectos técnicos e formais dos demais parágrafos. Desta maneira, deve apresentar Parágrafo de Opinião com a seguinte redação:

Examinamos as demonstrações contábeis da Companhia ABC, que .......

Em nossa opinião, exceto pelos efeitos do assunto descrito na seção a seguir intitulada "Base para Opinião com Ressalva", as demonstrações contábeis acima referidas apresentam adequadamente,.........

Neste parágrafo, deve-se fazer uso das palavras "exceto por...", "exceto quanto........", "com exceção de......", e "exceto pelos efeitos dos assuntos descritos no parágrafo Base para Opinião Com Ressalva", as quais são características definidoras deste tipo de opinião. Portanto, quando o auditor expressar uma "Opinião com Ressalva" devido à distorção relevante nas demonstrações contábeis, ele deve especificar que, em sua opinião, exceto pelos efeitos dos assuntos descritos na seção "Opinião com Ressalva":

(a) as demonstrações contábeis estão apresentadas adequadamente, em todos os aspectos relevantes (ou apresentam uma visão verdadeira e justa) [...], de acordo com [a estrutura de relatório financeiro aplicável], quando o relatório é emitido de acordo com uma estrutura de apresentação adequada; ou

(b) as demonstrações contábeis foram elaboradas, em todos os aspectos relevantes, de acordo com [a estrutura de relatório financeiro aplicável], quando o relatório é emitido de acordo com uma estrutura de conformidade.

\section{Exemplo de Parágrafo Base par Opinião com Ressalva.}

Os estoques da Companhia estão apresentados no balanço patrimonial por \$ xxx. $A$ administração não avaliou os estoques pelo menor valor entre o custo e o valor líquido de realização, mas somente pelo custo, o que representa um desvio em relação às práticas contábeis adotadas no Brasil. Os registros da companhia indicam que se a administração tivesse avaliado os estoques pelo menor valor entre o custo e o valor líquido de realização, teria sido necessária a provisão de \$ xxx para reduzir os estoques ao valor líquido de realização. Consequentemente, o lucro líquido e o patrimônio líquido teriam sido reduzidos em $\$ x x x$ e \$xxx, respectivamente, após os efeitos tributários. (NBC TA 705).

\subsection{Estrutura do Relatório com Opinião do Tipo Modificada da Espécie Adversa}

Quando o Auditor verificar a existência de efeitos que, isolada ou conjugadamente, forem de tal relevância que comprometam o conjunto das demonstrações contábeis, ele DEVE emitir opinião do tipo adversa. Nesse sentido, o auditor deve modificar a opinião no seu relatório quando: (i) concluir, com base na evidência de auditoria obtida, que as demonstrações contábeis como um todo 
apresentam distorções relevantes; ou (ii) não conseguir obter evidência de auditoria apropriada e suficiente para concluir que as demonstrações contábeis como um todo não apresentam distorções relevantes. Quando o Auditor emitir opinião modificada, desta natureza, deve incluir descrição clara de todas as razões que fundamentaram o sua opinião e, se praticável, a quantificação dos efeitos sobre as demonstrações contábeis. Neste caso, o Auditor deve a deve apresentar o Parágrafo de Opinião com a seguinte redação:

Exemplo de Parágrafo Opinião Adversa.

Examinamos as demonstrações contábeis consolidadas da Companhia $A B C$ (Companhia) e suas controladas, que compreendem o balanço patrimonial consolidado, em 31 de dezembro de 20X1, e as respectivas demonstrações consolidadas do resultado, do resultado abrangente, das mutações do patrimônio líquido e dos fluxos de caixa para o exercício findo nessa data, bem como as correspondentes notas explicativas, incluindo o resumo das principais políticas contábeis. (NBC TA 705).

Em nossa opinião, devido à importância do assunto discutido no parágrafo a seguir intitulado "Base para Opinião Adversa", as demonstrações contábeis consolidadas acima referidas não apresentam adequadamente, em todos os aspectos relevantes, a posição patrimonial e financeira consolidada da Companhia $A B C$ e suas controladas, em 31 de dezembro de 20X1, o desempenho consolidado de suas operações e os seus fluxos de caixa consolidados para o exercício findo nessa data, de acordo com as práticas contábeis adotadas no Brasil. (NBC TA 705).

Exemplo de Parágrafo Base para Opinião Adversa, apresentado na NBC TA 705.

Conforme explicado na Nota $X$, a Companhia não consolidou a controlada XYZ, adquirida durante 20X1, devido ao fato de não ter sido possível determinar os valores justos de certos ativos e passivos relevantes dessa controlada na data da aquisição. Esse investimento, portanto, está contabilizado com base no custo. De acordo com as práticas contábeis adotadas no Brasil, a controlada deveria ter sido consolidada. Se a controlada XYZ tivesse sido consolidada, muitos elementos nas demonstrações contábeis consolidadas acima referidas teriam sido afetados de forma relevante. Os efeitos da não consolidação sobre as demonstrações contábeis consolidadas não foram determinados.

Nossa auditoria foi conduzida de acordo com as normas brasileiras e internacionais de auditoria. Nossas responsabilidades, em conformidade com tais normas, estão descritas na seção a seguir, intitulada "Responsabilidades do auditor pela auditoria das demonstrações contábeis". Somos independentes em relação à Companhia e suas controladas, de acordo com os princípios éticos relevantes previstos no Código de Ética Profissional do Contador e nas normas profissionais emitidas pelo Conselho Federal de Contabilidade, e cumprimos com as demais responsabilidades éticas de acordo com essas normas. Acreditamos que a evidência de auditoria obtida é suficiente e apropriada para fundamentar nossa opinião adversa.

\subsection{Estrutura do Relatório com Opinião do Tipo Modificada da Espécie Com}

\section{Abstenção de Opinião}

A estrutura formal do relatório, neste tipo de opinião, também é impactada, 
principalmente nos parágrafos: Opinião e Base para Opinião e devem ser expressados com a utilização de palavras que a caracterizam.

Neste caso, quando o auditor se abstém de expressar uma opinião devido à impossibilidade de se obter evidência de auditoria apropriada e suficiente, ele deve:

(I) especificar que ele não expressa opinião sobre as demonstrações contábeis;

(II) especificar que, devido à relevância dos assuntos descritos na seção "Base para abstenção de opinião", o auditor não conseguiu obter evidência de auditoria apropriada e suficiente para fundamentar sua opinião de auditoria sobre as demonstrações contábeis; e

(III) alterar a declaração requerida pelo item 24(b) da NBC TA 700, que indica que as demonstrações contábeis foram auditadas, para especificar que o auditor foi contratado para auditar as demonstrações contábeis, , como pode-se constatar nos exemplos de redação, a seguir apresentados.

\section{Exemplo de Parágrafo de Opinião, do tipo Abstenção, apresentado na NBC TA} 706.

Fomos contratados para examinar as demonstrações contábeis consolidadas da Companhia ABC (Companhia) e suas controladas, que compreendem o balanço patrimonial consolidado, em 31 de dezembro de 20X1, e as respectivas demonstrações consolidadas do resultado, do resultado abrangente, das mutações do patrimônio líquido e dos fluxos de caixa para o exercício findo nessa data, bem como as correspondentes notas explicativas, incluindo o resumo das principais políticas contábeis.

Não expressamos uma opinião sobre as demonstrações contábeis consolidadas da Companhia $A B C$ e suas controladas pois, devido à relevância do assunto descrito na seção a seguir intitulada "Base para abstenção de opinião", não nos foi possível obter evidência de auditoria apropriada e suficiente para fundamentar nossa opinião de auditoria sobre essas demonstrações contábeis consolidadas.

\section{Exemplo de Parágrafo Base para Abstenção de Opinião, apresentado na NBC} TA 706.

O investimento da Companhia no empreendimento controlado em conjunto Empresa XYZ está contabilizado por \$ XXX no balanço patrimonial consolidado, o que representa mais de $90 \%$ do seu patrimônio líquido, em 31 de dezembro de 20X1. Não nos foi permitido acesso à administração e aos auditores da Empresa XYZ, incluindo a documentação de auditoria do auditor da Empresa XYZ. Consequentemente, não foi possível determinar se havia necessidade de ajustes em relação à participação proporcional da Companhia nos ativos da Empresa $X Y Z$ que ela controla em conjunto, assim como sua participação proporcional nos passivos da Empresa $X Y Z$, pelos quais ela é responsável em conjunto, e sua participação proporcional nas receitas, despesas e nos elementos componentes das demonstrações das mutações do patrimônio líquido e dos fluxos de caixa do exercício findo nessa data. 


\section{I CONSIDERAÇÕES FINAIS}

A fase finalística do processo de Auditoria das Demonstrações Contábeis é materializada pelo relatório final de auditoria. Este documento técnico-legal deve ser redigido e/ou estruturado de acordo com as normas técnicas internacionais de auditoria que, no Brasil, são representadas pelas NBC TAs.

Do conjunto de NBC TAs aprovadas pelo CFC, por meio de Resoluções, destacam-se as NBC TAs 700, 705 e 706, as quais tratam dos tipos de opiniões a serem exaradas e regras referentes aos parágrafos bases para o tipo de opinião, definida pelo auditor ou equipe de auditoria e da inclusão ou não dos parágrafos de ênfase e de outros assuntos.

Este regramento técnico-científico, legal e estrutural, proporciona consistência ao relatório do auditor, na medida em que ajuda a promover o entendimento dos usuários e a identificar circunstâncias não usuais quando elas ocorrem. Assim sendo, a estrutura, o tipo e espécie de opinião, bem como as demais formalidades exigidas, têm por finalidade padronizar e qualificar o trabalho do auditor, informando aos usuários, do relatório final do auditor independente, sobre o contexto e condições de situação e apresentação das demonstrações contábeis auditadas. Nesse sentido, o tipo e espécie de opinião, posição e redação do conteúdo dos parágrafos e demais formalidades técnica-estruturais, expressas no relatório, procuram retratar se as demonstrações contábeis cumpriram a "estrutura de relatório financeira aplicável e/ou exigida" para aquela entidade, gerando padronização dos relatório e aumento da credibilidade por meio do aumento da segurança de que as demonstrações contábeis foram ou não foram elaboradas de acordo com as normas internas e internacionais de Auditoria.

\section{REFERÊNCIAS}

BRASIL, 2011. Tribunal de Contas da União. Auditoria Governamental Coordenador: Antonio Alves de Carvalho Neto. - Brasília: TCU, Instituto Serzedello Corrêa, 2011. Disponível em: <www.tcu.gov. br>. Acesso em 05 de maio de 2015.

CFC. Conselho Federal de Contabilidade. NBC TA700. https://cfc.org.br/tecnica/normas-brasileirasde-contabilidade/. Janeiro de 2020.

CFC. Conselho Federal de Contabilidade. NBC TA705. https://cfc.org.br/tecnica/normas-brasileirasde-contabilidade/. Janeiro de 2020.

CFC. Conselho Federal de Contabilidade. NBC TA706. https://cfc.org.br/tecnica/normas-brasileirasde-contabilidade/. Janeiro de 2020.

CREPALDI, 2010. Auditoria Contábil: teoria e prática. 6. ed. São Paulo : Atlas, 2010. 


\section{LA URGENCIA DE PERSPECTIVAS PLURALES EN LOS ESTUDIOS SOCIALES Y ORGANIZACIONALES}

Data de aceite: 11/03/2020

\section{Edgar Varela Barrios}

PhD en Administración

HEC- Universidad de Montreal, Rector de la Universidad del Valle, Cali, Colombia

Ernesto José Piedrahita

Comunicador Social, Administrador, Mg en Administración de Empresas. Director de Comunicaciones Universidad del Valle, Colombia

RESUMEN: La urgencia de desarrollar estudios organizacionales y sociales que incluyan teorías de diversas escuelas de pensamiento en el campo de la sociología en lo relativo a estudios sobre lo organizacional, para lograr profundizar y complejizar en sus resultados e incluso renovar opciones de orden epistémico que den cuenta de nuevas problemáticas y de nuevas alternativas de soluciones, obliga a acoger la opción de incorporar de forma combinada de distintos autores, incorporando a la labor investigativa, sustentada en teorías, metodologías y conceptos que por separado han logrado desarrollos y aportes, pero que, debido en muchos casos a razones de ideología o de mal entendida rigurosidad científica, no han dialogado entre sí.

En el presente trabajo se plantea la opción de establecer estudios de carácter plural con elementos centrales de la base teórica que ofrecen las escuelas de Niklas Luhmann y Jurgen Habermas. Ambos lograron erigir teorías sociológicas de amplio impacto y utilización para múltiples utilizaciones. Es en la visión sobre la modernidad, sus limitaciones, sus metas infructuosas y también sus posibilidades, en donde se presenta una de las más importantes coincidencias de estos dos grandes teóricos del siglo XX. A partir de allí, se pueden plantear innumerables temas de investigación que recojan además los grandes aportes de la teoría de sistemas y de la teoría crítica en relación con la comunicación, desde la cual ambos construyen buena parte de sus edificios teóricos. Los temas organizacionales, y en especial aquellos que tienen que ver con la situación geopolítica mundial y en ella el papel de los Estados Unidos y su actual gobierno, representan unas de las muchas maneras de establecer formas plurales de utilización de las dos teorías.

ABSTRACT: The urgency of developing organizational and social studies that include theories of various schools of thought in the field of sociology in relation to studies on the organizational, in order to deepen and complex their results and even renew epistemic options that account for new problems and new 
alternatives of solutions, forces to accept the option of incorporating in a combined way of different authors that incorporates, in the research work, based on theories, methodologies and concepts that have separately achieved developments and contributions, but that, due in many cases to reasons of ideology or of misunderstood scientific rigor, have not dialogued with each other.

In the present work the option of establishing plural studies with central elements of the theoretical base offered by the schools of Niklas Luhmann and Jurgen Habermas is proposed. Both managed to erect sociological theories of wide impact and use for multiple uses.

It is in the vision of modernity, its limitations, its fruitless goals and also its possibilities, where one of the most important coincidences of these two great theorists of the twentieth century is presented. From there, innumerable research topics can be raised that also include the great contributions of systems theory and critical theory in relation to communication from which both build much of their theoretical buildings. Organizational issues, and especially those that have to do with the global geopolitical situation and in it the role of the United States and its current government, represent one of the many ways of establish plural forms of use of the two theories

PALABRAS -CLAVE: Pluralidad, escuelas, organizacional, Luhmann, Habermas.

Si como planteara el sociólogo alemán Niklas Luhmann, "los sistemas de funciones de la sociedad moderna se describen a sí mismos", pretendiendo el criterio de cientificidad en el sistema del derecho, de la política, de educación o del sistema de la economía, dicho planteamiento se aplica también para los sistemas organizacionales en específico. La auto-referencia del mundo organizacional requiere ser revisada de forma constante y con múltiples instrumentos teóricos incluidas las teorías luhmannianas y destacando la comunicación con el fin de precisar cuáles son los factores de diferenciación por medio de los cuales estos sistemas (las organizaciones) establecen sus entornos. Se trata de analizar precisamente los criterios cientificistas con los que se sustentan las organizaciones modernas, todo ellos desde una perspectiva de sistemas que además deberá incorporar herramientas metodológicas aportadas por otras escuelas sociológicas.

El aporte de pensadores como Luhmann intenta precisamente ofrecer una visión totalizante a estas realidades interpretando la complejidad de sus interrelaciones internas y las del sistema frente a su entorno. En este marco, establecer lecturas profundas sobre las dinámicas de los elementos constitutivos de los sistemas organizacionales y de su entorno, permitirá arrojar múltiples resultados que enriquecen los análisis sobre el mundo organizacional y sus distintos componentes.

Sus críticos, recusan a Luhmann por haber construido una teoría que excluye a los hombres de la sociedad porque sería la única manera con la que su propuesta - considerada radical-puede resolver este problema. Habrá que sopesar aquello que 
se da en llamar "exclusión del hombre" para precisar sus alcances reales, en vista de que, si la comunicación está presente, difícilmente podría hablarse de una "exclusión plena" del hombre. Además, si por un lado se requiere evitar que se desdibuje el sujeto como ámbito analítico (Varela. 2014) ¿ ¿No es acaso necesario también superar el individualismo metodológico? Las teorías sustentadas en el libre albedrío, tan frecuentes en los estudios organizacionales y en el management en general pueden contrarrestarse de forma radical con la teoría de sistemas de Luhmann.

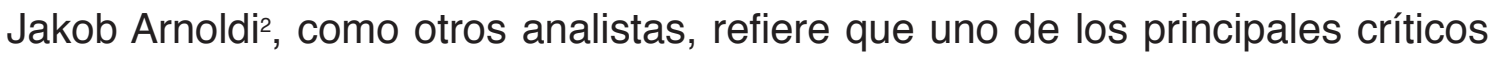
de Luhmann es Jürgen Habermas, quien sostiene un concepto de comunicación con centralidad en el sujeto y una teoría social con principios normativos universales, mientras que la teoría de los sistemas sociales del sajón se orienta sobre principios que son auto-referenciales.

\section{ELEMENTOS EPISTEMOLÓGICOS}

Luhmann representa una visión renovada y en muchos aspectos, prístina de los estudios sociales, sistémicos y organizacionales. Sustenta que en el pasado las autoridades gerenciales o políticas tomaban las decisiones sobre la formación y los ajustes estructurales de las organizaciones, según las condiciones ambientales, mientras que en la actualidad las organizaciones conceptualizan su propia relación con el entorno como decisión. Cabe señalar que todo esto acontece en un mundo organizacional altamente complejo y que cuenta con un elemento fundamental, la comunicación. Su aporte permite no sólo explicar la permanencia de un sistema en un ambiente difícil, sino que posibilita conocer su dinámica interna en la interrelación de sus elementos, su flujo comunicacional, sus componentes autopoiéticos. De otra parte, se trata de aprovechar la equivalencia funcional entre diversas causas posibles en vista de un efecto problemático y la posibilidad de varias causas posibles con el mismo efecto, reseñada por D. Zolo ${ }^{3}$. La relación sistema-entorno promovida por los ecólogos, los biólogos y por la vieja escuela de Bertalanffy, es apenas un fragmento del universo analítico sistémico que Luhmann acrecienta de manera exponencial.

Otro de los rasgos característicos de la epistemología sustentadora de su obra son los elementos de la perspectiva dialéctica que acoge cuando destaca que las ideas también tienen una realidad que cambia la realidad (no es positivista en el sentido de que no es realista, pero tampoco es nominalista). Plantea así mismo que "el observador científico puede ser considerado como un sistema auto-referencial similar a las organizaciones y que, posturas teóricas de este tipo no solo revolucionan la epistemología clásica de sujeto-objeto; desdogmatizan y naturalizan la teoría científica,

1Varela, Edgar.Coloquio de Epistemologia. Florianopolis, Brasil. 2014

2 Arnoldi, Jakob "Niklas Luhmann. An introduction", en Theory, Culture \& Society, vol. 18, núm. 1, 2001, pp. 1-13.

3 Zolo, Danilo, "Function, Meaning, Complexity, The Epistemological Premises of Niklas Luhmann's 'Sociological Enlightenment', en Philosophical Social Sciences, núm. 16, 1986.P 118 
sino que producen una comprensión más completa del objeto por medio del diseño de una teoría a su vez más compleja".

Ancladas en una base conceptual netamente cibernética, estas tesis plantean un reto para quienes participan en investigaciones sociales y sobre las organizaciones. El cientifismo presente un muchas de las teorías administrativas, es puesto en crisis por Luhmann al fracturar uno de los puntos de partida de la ilustración sobre la necesaria objetividad de los estudios socio-organizacionales. Si se tiene en cuenta que la descripción de objetos sociales -en este caso organizaciones-, mediante atributos y características, satisface un requisito prioritario y peculiar de la ciencia social, se plantea que la construcción teórica plural debe nutrir, potenciar y complejizar esa descripción.

A diferencia de las teorías de las llamadas ciencias naturales, las teorías de las ciencias sociales son construcciones sociales compartidas por los seres humanos que escapan a la percepción de los sentidos. Su descripción en calidad de objetos, la construcción de las categorías que contienen a su vez los atributos sistémicos de las organizaciones, y, por último, su categorización debe establecerse también con sentido de pluralidad teórica con el fin de enriquecer los resultados. Luhmann construye el sentido de lo que denomina auto descripciones, las cuales son símiles de la autopoiesis, categoría elaborada por Humberto Maturana, sobre lo cual destaca que: "el sistema de la sociedad está obligado a observar sus propias comunicaciones: en este sentido debe realizar una observación continua (...) el mismo produce su propia forma, es decir, produce la diferencia entre sistema y entorno"4. Este es uno de los más importantes aportes del sociólogo teutón y a su vez, uno de sus teorías más cuestionadas al considerarse, en muchos casos, como una visión deshumanizante.

Un componente de la apuesta epistémica de Luhmann se sustenta fuertemente en las elaboraciones del biólogo Maturana, y es clara, como el caso del chileno, su ruptura con el dualismo, porque "es el propio sistema quien produce su entorno". Otro elemento que lo asocia con Maturana es la preponderancia del lenguaje ya que toda las autodescripciones o autobservaciones se producen en la comunicación y el lenguaje, y sólo por ello pueden ser descritas y observadas. Así mismo, combina los sistemas autocorrectivos, la comunicación y sociedad señalando que "es una peculiaridad válida también para el sistema social de la sociedad, y aquí naturalmente es válida con mayor razón porque fuera de la sociedad no existen posibilidades de comunicación, y, por tanto, no existen instancias autorizadas para hacer correcciones. Con mayor razón entonces la sociedad está destinada a practicar una autorreferencia sin criterios"5. Se advierte aquí, que autorreferencia no es autarquía y que los actores individuales, personas, no quedan "a expensas" de lo que la organización en su conjunto realice.

Estudios portentosos sobre temas como las religiones, le permiten comparar las

\footnotetext{
4 Luhmann, N. "Teoría de la Sociedad" pp 381.

5 Luhmann, N. "Idem" pp 385

6 Luhmann, N. "Idem" pp 385
} 
autodescripciones medievales y modernas ${ }^{6}$, y concluir acerca de la alta complejidad y el rol no neutral del observador, pone en crisis la cientificidad propia de la ilustración. Sin embargo, Luhman no rechaza la modernidad. Se expresa así, que el proyecto de modernidad está inconcluso. Critica segn la cual los cambios estructurales del pasado reciente nunca han sido observados y descritos completamente, sino con la ayuda de conceptos considerados por él como completamente inadecuados y manifiesta su impresión de que la modernidad está solo en sus inicios. La evidente insatisfacción por todo lo que se ofrece actualmente podría convertirse en un inicio más fecundo.

Antes que Luhmann, otros analistas habían rechazado la teoría de que las organizaciones corresponden a los individuos que las integran. Richard Hall y Niklas Luhmann coinciden en que las organizaciones son realidades distintas e independientes de los individuos que las conforman, y que, como tales, toman decisiones y responden a una racionalidad propia. Hall (1996). Señalan que las organizaciones fuerzan a sus miembros a tomar decisiones y actuar de ciertas maneras. Las organizaciones son también actores con una existencia en sí mismas, por encima y más allá del desempeño de los individuos que las conforman. Pueden además analizar sus ambientes y tienen "creencias". Para Luhmann "las organizaciones conceptualizan sus relaciones con el entorno como decisión. Se certifican a sí mismas como anotación de actas y, en propiedad decide el sistema social organización.

Uno de los desarrollos cruciales en la teoría luhmanniana en relación con lo social y con lo organizacional, es el concepto de comunicación. Este elemento tiende puentes con otras teorías sociológicas de amplio desarrollo en las últimas décadas. Los chilenos Darío Rodríguez y Marcelo Arnold ubican ese momento de desarrollo teórico como el que posibilita la concreción del giro de la teoría general de sistemas a la teoría de sistemas sociales. Para Eva Knodt, por su parte, el desarrollo del "giro comunicativo" es de tal magnitud como el "giro autopoiético". Rudolph Stichweh (2000:8) también calificó como cimero este desarrollo, al afirmar la centralidad de la elevación luhmanniana de la comunicación al rango de concepto fundamental para la sociología, y en general las ciencias sociales.

Por largo tiempo y en el presente, el componente comunicativo hace parte de los asuntos de mayor relevancia en la teoría Luhmanniana y en el abordaje de múltiples estudios sociales y organizacionales en unión con otras perspectivas comunicativas, más renombradas en el campo a comienzos de los años ochenta (como la teoría de la acción comunicativa de Habermas o la hermenéutica del entendimiento de Gadamer).

Sistemas que se reproducen a sí mismos y que son capaces de auto-observarse, son sustentos centrales de la obra de Luhmann que hoy por hoy orientan a innumerables estudios organizacionales. Ante esto vale la pena preguntarse, por ejemplo, ¿cuál o cuáles deberían ser las unidades de análisis más óptimas para el estudio de lo organizacional desde la perspectiva Luhmanniana y previendo una combinatoria con otras teorías sociológicas y de otras disciplinas o ciencias?

Frente a esto y en principio, las opciones son muy diversas: una empresa, 
un conjunto de empresas, un sector empresarial de una región o un país, una multinacional de las del top mundial, un sector empresarial mundial y la sumatoria de todas las empresas de un país, entre otras muchas opciones. Frente a estas, también establecer sus entornos y por supuesto, los factores de diferenciación de las empresas en calidad de sistemas. Los objetivos generales de la teoría Luhmanniana deben, por supuesto, ser tenidos en cuenta para su aplicación integral en los estudios sobre organizaciones aun cuando sean de tipo ecléctico. Algunos de los más citados son: ofrecer nuevos temas de interés, nuevos estímulos conceptuales y nuevos problemas; Ofrecer posibilidades de diferenciación; propiciar observaciones eficaces y evaluarse por las observaciones que posibilita su aplicación; lograr la reducción de complejidad y constituirse ella misma en un referente (ser reflexiva y aotorreferente).

A pesar que cada vez hay mayor difusión y utilización de la perspectiva de Luhmann para múltiples y muy diversos estudios relativos a lo social y lo organizacional, ha sido también desconocida o soslayada por diversos autores de amplio reconocimiento en el mundo de la teoría organizaciones sin tener en cuenta que es uno de los máximos exponentes de la sociología contemporánea. Henry Mintzberg, por ejemplo, en su libro "Safari a la estrategia" (1999) en el cual realiza una clasificación de las distintas escuelas mediante las cuales se diseña, analiza o implementan las estrategias administrativas, involucra la escuela ambiental como paradigma de la escuela sistémica. En su descripción no tiene en cuenta a Niklas Luhmann y sus tesis, a pesar de que a finales de los 90 , ya se conocía la mayor parte de la producción intelectual del extinto pensador. Muy probablemente el grado de abstracción y complejidad de estas teorías llevó a requiere algo más que una revisión panorámica como la utilizada en el famoso libro del canadiense. Por supuesto, los aportes realizados por Luhamann a la reflexión sobre las organizaciones superan en grado extremo las tesis de los ecologistas, tenidas en cuenta por Mintzberg para describir el enfoque sistémico como componente clave y decisivo de la teoría organizacional. En relación con Mintzberg y esta obra en específico, Varela Barrios (2015) señala las limitaciones de la intención abarcadora de este tipo de teorías organizacionales, construidas sobre la base de taxonomías. El planteo plural del presente trabajo apunta a recalcar en la prioridad de involucrar análisis de mayor densidad y complejidad en los estudios organizacionales incorporando teorías de amplio aporte a este campo como las de Luhmann y otros autores de áreas como las ciencias políticas, la bioingeniería, la ingeniería física, entre otras muchas.

\section{LUHMANN Y HABERMAS, ¿TEORÍAS ABSOLUTAMENTE IRRECONCILIABLES?}

En los años 70 y 80 del siglo XX el debate Luhmann- Habermas copó la atención del mundo académico y se promovieron, basados en los propios debates en los cuales participaron directamente de los sociólogos alemanes, las tesis en cuanto a la imposibilidad de adelantar investigaciones o estudios que contemplaran algún nexo 
entre ambas escuelas. El pluralismo teórico y metodológico propuesto en el campo organizacional debe apuntar a vislumbrar y establecer de forma acertada nuevas formas de abordar, desde distintas vertientes teóricas consideradas en muchos casos como contrarias e irreconciliables, asuntos cruciales para el estudio de las organizaciones.

Niklas Luhmann y Jurgen Habermas representan dos de las más importantes escuelas de las ciencias sociales en los últimos 50 años. Por esto, esfuerzos para establecer un diálogo entre estas dos fuentes teóricas resulta ampliamente enriquecedor. Para Habermas el problema, sujeto-objeto, reside en una concepción metafísica del sujeto. Para ello ve como una alternativa la filosofía del lenguaje en donde los límites entre significado real y metafórico, entre lógica y retórica, entre habla seria y habla ficción quedan disueltos en el acontecer textual.El filósofo y sociólogo alemán dice que los pensadores postestructuralistas abandonan la autocomprensión cientificista y con ello el último momento que aún restaba del concepto de razón desarrollado en la edad moderna. Concluye que así, todas las pretensiones de validez se tornan inmanentes al discurso, y quedan simultáneamente absorbidas en el todo del ciego acontecer de discursos ${ }^{10}$. Si bien, como sucede con Maturana, Habermas logra activar una carga de profundidad que hace añicos el dualismo que ha esgrimido la modernidad por siglos, y con él su empiria objetiva-referencial; sigue aferrado a que la solución puede provenir de la propia modernidad.Las dos teorías sustentan una propuesta holística sobre la sociedad contemporánea teniendo como elemento sustancial la complejidad. Ambas superan las explicaciones tradicionales sobre la sociedad y establecen nuevos componentes epistemológicos que enriquecen o complementan las maneras de abordar lo social. Más allá de las discusiones de orden político, tema a través del cual habría barreras que impiden un acercamiento entre las dos teorías y que en muchos asuntos llevan a posturas inconciliables, es necesario revisar formas de acercamiento a las realidades sociales y organizaciones utilizando valiosas herramientas conceptuales de los dos autores.

La autoemancipación de la especie humana y su autonconstitución, sugerida por Habermas como un propósito que recoge la llamada "tradición sociológica ilustrada", debe enlazarse en algunos tópicos con el propósito de Luhmann, quien, según plantean analistas como Izuzquiza, busca a través de su constructo teórico, "la ilustración de la ilustración" en el sentido de hallar los valores y fundamentos que constituyen la sociedad moderna con una teoría sociológica permita una descripción general de la sociedad. Se esgrime por parte de quienes ven insalvable la distancia entre estas dos teorías, que éstas no puedan ser utilizadas en forma conjunta en vista de que la razón ilustrada, y a través de ella, la humanización de la sociedad,- que constituye la más alta de la teoría Habermasiana-, riñe con la postura de Luhmann quien vio en la razón ilustrada un obstáculo para explicar las dinámicas de la sociedad contemporánea.

Teniendo en cuenta diversos aspectos basales de la completa obra que en su

10 Habermas, J. "Pensamiento Postmetafísico" pp 244 
conjunto y por más de cuatro décadas construyó Luhmann en torno de la sociología, es apreciable que sus propósitos fundamentales no riñen plenamente con los de Habermas. Son más bien los elementos o constructos para el estudio de las realidades sociales, los que establecen las diferencias. Ello genera precisamente el reto de establecer miradas que reconozcan la alta complejidad y permitan una aplicación eficaz de metodologías al tiempo que se detallan las diferencias epistémicas de las dos teorías con el fin de establecer una lectura clara, amplia y precisa sobre la sociedad y las organizaciones actuales. Los aportes conceptuales de Habermas y Luhmann en lo relativo al papel de la comunicación en las relaciones de la sociedad, deben ocupar un lugar privilegiado para ser utilizados como pilares teórico-conceptuales de las investigaciones que se aborden de forma plural, no solo en vista de las grandes fortalezas de las dos escuelas en este tema sino por ser uno de los elementos que a su vez puede servir como puente entre las dos escuelas sociológicas.Según destaca Varela Barrios (2014) "para Luhmann la comunicación no estriba en explicar simplemente la relación en la que dos individuos racionales transfieren contenidos comunicativos entre $\mathrm{A}$ y $\mathrm{B}$, sino que él, la interpreta como una interacción sistémica, no de individuos, sino de los elementos que configuran los sistemas". Según el experto en organizaciones, un importante aporte de la teoría de sistemas de Luhmann es la diferenciación que hace de la comunicación y la información. La una es redundante, repetitiva, mientras que la comunicación permite registrar datos nuevos, ser original y singular. El sistema del que habla Luhmann, a diferencia de Parsons, no es un macro sistema, sino que todo lo que no es un ente, lo considera como su entorno. Todo ente, a su vez, es un sistema y hace parte del entorno de otro, y se relaciona con su entorno a través de la diferencia (es decir, la comunicación). En la teoría organizacional, estos planteamientos son anticipados por Barnard que contiene una visión de la comunicación desprovista del racionalismo subjetivo desde esta perspectiva sistémica. Ello le permite diferenciar entre la comunicación intraorganizacional e interorganizacional.

Habermas se ubica como figura de la tradición clásica de la sociología alemana en la que aparecen como figuras cimeras Carlos Marx y Max Weber, también representa como pocos la razón ilustrada y la moral kantiana, por lo cual muchos ven como imposible que su obra pueda establecer nexos con otros autores de escuelas consideradas contrarias en términos de las epistemes que las sustentan. Se miran los planteamientos Luhmannianos como contrarios a dicha tradición y a éste como representante de una propuesta modernista o futurista que se contrapone en forma plena a la anterior. De otra parte, el esfuerzo de Luhmann por desarrollar una teoría específica de la sociedad en su conjunto, así como la consolidación de un edificio teórico que se sustenta recogiendo tesis en las llamadas "ciencias duras" no puede verse como una abstracción inoficiosa e imposible de asir - reconocido que es altamente abstracta- para lo correspondiente a los análisis y estudios organizacionales. Tampoco estas condiciones de las teorías de Luhmann representan un imposible lograr conjugar herramientas de análisis con las de su compatriota. En cuanto a la teoría general 
de la sociedad elaborada por Luhmann, tendrá por supuesto aspectos de mayor o menor nivel de desarrollo y concreción, pero sin duda servirá para establecer análisis de gran riqueza sobre la vida social y de las organizaciones al igual que sucede con las teorías habermasianas. Teóricos norteamericanos como R. Hall, por ejemplo, presentan, en comparación con la perspectiva luhmanniana una distinción entre las decisiones personales y las consecuencias colectivas que afectan la organización. Reconociendo criterios de este tipo, también es necesario resaltar a la manera de Luhmann que muchas de las decisiones clave para las organizaciones son decisiones del tipo organizacional en donde el criterio de las personas refuerza dicho carácter organizacional con base precisamente en los procesos comunicativos. Esto dista de llegar a concluir que por ello se toma una decisión más o menos imperfecta o eficaz. pero sí podría -luego de los análisis respectivos- llevar a la conclusión de que el elemento comunicacional reduce los niveles de incertidumbre organizacionales al marcar un camino a seguir, así sea errado o desacertado.

Un ejemplo, sobre los muchos aspectos que pueden ser abordados desde una visión que combine las teorías mencionadas, es el de la decisión. Sobre este asunto, la controversia Luhmann- Habermas es una de las más comentadas y recogida por muchos para argumentar sobre la inviabilidad de trasegar de forma simultánea las dos vías que abren estas importantes escuelas. En materia de decisiones, Luhmann expresa que las consecuencias y resultados de decisiones tomadas por individuos en el plano organizacional son decisiones organizacionales sistémicas, un punto neurálgico de controversia con Guiddens (1997) y Habbermas a lo largo de las últimas décadas del siglo XX.El asunto de la decisión, al igual que otros muchos conceptos distintivos o emblemáticos de la teoría organizacional, requiere combinatorias de análisis sistémico y crítico, en la búsqueda de encontrar elementos que caractericen la toma de decisiones organizacionales, sus limitaciones, sus posibilidades, su carácter humano o no humano, su impacto en el entorno, su reproducibilidad, entre otros muchos elementos. Por esto, buscar elementos de enlace o complementariedad entre categorías y conceptos de las dos escuelas es enriquecedor y aportante en la vía de encontrar realidades no analizadas o superar los niveles de exhaustividad de realidades analizadas hasta ahora en el mundo de las organizaciones.

Entre los autores hay coincidencias en la visión sobre el tiempo, la modernidad y el presente. Luhmann caracteriza la era actual señalando la preeminencia del futuro y destacando que "únicamente en el presente, sólo en el contexto de un mundo dado en la simultaneidad, se es capaz de decidir y actuar". Habermas por su parte recalca en el nuevo valor de lo transitorio, lo elusivo y efímero, la misma celebración del dinamismo, revela el anhelo de un presente impoluto, inmaculado y estable.Escuelas disímiles en muchas de sus propuestas, llegan por caminos muy distintos a conclusiones similares acerca de la modernidad. La sociología crítica de Habermas y la sociología de sistemas apuntarían a llenar vacíos que la modernidad ha generado o no ha logrado 11 Habermas, J. y otros. "La Posmodernidad" pp 28. 
cubrir. Para Habermas, el proyecto de la modernidad desplegó su mayor impulso en el siglo XVIII'11 representa y representaba lograr una ciencia objetiva, leyes universales y morales y un arte autónomo e impulsor del cambio social. Con una visión elitista de la cultura - se buscaba la instauración de lo que M. Barbero llama "la cultura culta" y que algunos llaman cultura especializada, se aspiraba al "enriquecimiento" de la vida cotidiana. Habermas comenta que "Los pensadores de la llustración con la mentalidad de un Condorcet aún tenían la extravagante expectativa que las artes y las ciencias no sólo promoverían el control de las fuerzas naturales, sino también la comprensión del mundo y del yo, el progreso moral, la justicia de las instituciones e incluso la felicidad de los seres humanos"

La utopía ilustrada, según este autor, no se ha realizado porque la excesiva especialización ha impedido el aprovechamiento del componente tecnocientífico y artístico para nutrir la vida cotidiana, recibiendo ésta en buena medida, formas de manipulación natural y social. Fue infructuoso el esfuerzo de grupos de corrientes artísticas tales como los surrealistas por romper la autarquía del arte y forzar una reconciliación arte y vida.

El distanciamiento entre los ciudadanos del común y el arte se debió en opinión de Habermas a que se trató de incidir a través de una esfera de la cultura moderna, tal como aconteció con las iniciativas marxistas por intentar un cambio profundo únicamente desde la esfera social. Se propone en su lugar, un proyecto integrador del cambio para el progreso. El planteamiento de Habermas de no sepultar la modernidad sino aprender de los errores de ciertos programas "extravagantes" tales como el cultural y el marxista, es afín con el planteamiento de Lhumann, en el sentido de que falta mucho por desarrollar en la modernidad, utilizando para ello otros presupuestos epistemológicos.

Su visión de la modernidad es la de un proyecto inacabado. Luhmann a su turno afirma que ha habido desaciertos pero que el camino aun esta por recorrer. se trata de aprovechar el quiebre sistémico aplicado por Luhmann y Maturana junto con la eticidad y la prioridad en los aspectos humanísticos acentuados en la teoría de Habermas para revalorar los estudios organizacionales. Precisamente, para avizorar alternativas de neguentropía fomentadas desde el mundo o el sistema organizacional, será necesario establecer nuevas y sofisticadas formas de comprensión del mundo social y de los sociosistemas que inciden sobre la realidad humana actual.

El objetivo metodológico de Luhmann de abandonar la tradición cultural europea enraizada en la ilustración, no contradice en esencia el llamado de Habermas a encontrar en los desaciertos y debilidades epistémicas, conceptuales y procedimentales de la modernidad, la oportunidad de entender la sociedad.Así mismo, la descripción fiel a las realidades sociales, que representa la aspiración luhmanniana tampoco contraviene la condición de habermas para que la modernización social sea guiada en una dirección

12 Habermas, J. y otros. "La Posmodernidad" pp 34. 
diferente, con gente capaz de desarrollar instituciones propias que pongan límites a la dinámica interna y a los imperativos de un sistema económico casi autónomo, así como a sus complementos autónomos"12. También se señala como coincidencia, el que recalcan en la negativa preminencia de un sistema que ha tendido a hegemonizar a los otros: la economía.

Si los dos buscan refundar la modernidad, vale la pena preguntarse sobre los términos de esta refundación y en ella qué papel deberá tener el mundo organizacional. Volviendo a Luhmann un paso previo es lograr una descripción fiel de las realidades sociales organizacionales que permitan el sueño Habermasiano de una guía directiva diferente por parte personas y de gruposLas coincidencias en las críticas a la modernidad y en la urgencia de refundarla dan cuenta del pesimismo compartido frente a las opciones que otros plantean. La posmodernidad con sus acechanzas tecnológicas, ambientales, bélicas, conforma un fantasma frente al cual Luhmann ve un salta al vació de tipo futurista en un "post" y Habermas predice una reedición de errores del pasado lo que califica como conservadurismo.

\section{LA ACTUALIDAD, FUENTE DE INNUMERABLES TEMÁTICAS A ESTUDIAR DESDE UNA PERSPECTIVA PLURAL}

Con base en lo anterior, y previendo una utilización práctica de la teoría Luhmanniana y Habermasiana en temas urgentes y múltiples tomando como marco las macro-organizaciones cabe proponer el estudio de la realidad socio-histórica mundial sobre: migraciones, armamentismo, procesos políticos integracionistas, derechos humanos, alimentación en un presente altamente complejo y convulso. Todo esto de forma plural, incorporando diversas corrientes teóricas y fomentando la construcción de teoría social y organizacional, mirada desde la complejidad y con una visión abarcante.

La mixtura de análisis que combinan sustratos teóricos y metodológicos de diversos autores y escuelas sociológicas y organizacionales, permitirá sin duda enriquecer los acercamientos a aspectos de la realidad social de gran complejidad, sobre los cuales su entendimiento y apropiación ha sido infructuosa dada la casi infinita mezcla de factores de todo orden.

Es necesario -urgentemente necesario- revisar de manera sistémica y renovada - con aprovechamiento de un arsenal teórico amplio y diverso- la situación actual de asuntos como la injerencia mundial de la política norteamericana agenciada por el presidente Trump. La teoría de sistemas de Luhmann, y la Teoría crítica de Habermas, articuladas en diversos componentes posibilitarán descubrir aspectos cruciales sobre este asunto de gran interés, tanto para las organizaciones involucradas en relaciones con EE. UU, como para la sociedad norteamericana y mundial, en un período de gran confusión e incertidumbre. Si ubicamos a multinacionales como Ford, Toyota y otras, en calidad de elementos del sector automotor mundial como un solo sistema, y analizamos sus interacciones internas (operaciones al decir de Luhmann) 
, describiendo las funciones autoreferenciales de dicho sistema y las funciones hetero-refenciales (frente al entorno), se podrán conocer muchos de los asuntos que caracterizan su realidad organizacional. Revisar sus operaciones, precisar sus elementos autopoieticos (los cuales podrían ser auspiciados o promovidos a través de políticas de corte proteccionista como las que empezó a ejecutar la administración Trump, también posibilitarán conocer acerca de la actual situación y avizorar formas de intervención. O de aquellos elementos que, contrario a lo esperado por el mandatario estadinense y por los líderes corporativos del sector automotor, llevarán a la crisis de dicho sistema organizacional.

En relación con las organizaciones y su papel en la salvación o destrucción de la humanidad hay todo tipo de expectativas, predicciones y llamados. en muchas de las novelas, series televisivas y películas de los últimos tiempos se ofrecen visiones que van del optimismo extremo hasta los más oscuros panoramas apocalípticos. De igual forma, y con base en las políticas aplicadas por el Presidente norteamericano, podría analizarse la condición del Estado en calidad de sistema, frente el entorno empresarial mundial en una interrelación que desde la complejidad pueden permitir revisar sus operaciones y su autopoiesis (la del Estado y la sociedad norteamericanas).

Desde la perspectiva sistémica de Luhmann también cabe preguntarse qué aspectos de la comunicación, entre la sociedad norteamericana (sistema social) y se han visto afectados o incluso fracturados desde el inicio del mandato Trump, y cómo ello afectará la perdurabilidad del sistema sociedad-Estado norteamericano en los próximos años. Dichos análisis deben permitir establecer una prospectiva sobre temas claves para el mundo como éste que tiene a muchos actores en vilo y que incluso llegó a afectar el llamado "reloj del apocalipsis" que adelantaron 30 segundos hacia la medianoche de la humanidad, dado que los científicos atómicos coincidieron en que las declaraciones del presidente Trump generan incertidumbre y ensombrecen el estado de la seguridad global. Otros interrogantes que podrían ser resueltos o lograr un importante avance en su resolución utilizando las teorías combinadas de Luhmann y Habermas, son por ejemplo los atinentes a las opciones de cambio de los sistemas educativos en pues una de las más importantes conclusiones sobre los porqués de la crisis de la educación en nuestros países es la necesaria reorientación o el replanteo de los sistemas educativos. Descubrir los elementos y las características de los mismos, que permiten su reproducibilidad y perdurabilidad es un asunto central para lograr contrarrestarlos y cambiar dichos sistemas.

El managerialismo, como una de las expresiones más difundidas de la actualidad mundial en los distintos ámbitos de la sociedad moderna, requiere igualmente de numerosas investigaciones. Como lo afirma Varela (2015) ${ }^{13}$ recogiendo las tesis Luhmannianas, "el homo managerial es organizacional y vive en estructuras meso-

13 Managerialismo - culturas de empresa y emergencia del "hombre managerial". revista Fórum Doctoral número 6. enero - junio de 2015 ISSN: 2027-2146 
sociales de carácter doble, autoreferencial y hetero-referencial, sin ubicarse en un individualismo metodológico -no es en sí mismo individualista pues en las sociedades postmodernas nadie existe solo en una lógica auto-referencial en la que el egoísmo de sí mismo se postule como fundamento de la lógica social. Los postulados de la sociología posmoderna y de la filosofía política crítica. Luhmann, Foucault y Agamben brindan claves importantes para entender los fenómenos de interacción social de dicho hombre managerial”. En general, podría estudiarse también, de forma más genérica, cuáles son los factores endógenos (elementos) y las dinámicas comunicacionales que permiten la perdurabilidad de las empresas, gobiernos, regímenes políticos, sistemas de salud, y otros subsistemas, en momentos histórico-sociaels adversos o en situaciones cuyos entornos (políticos, económicos o ambientales) son hostiles o amenazantes.

\section{REFERENCIAS}

ARNOLDI, Jakob. Theory, Culture \& Society, vol. 18, edición febrero de 2001.

HABERMAS, Jurgen. Pensamiento Postmetafísico. Editorial Taurus. 1992.

HABERMAS, Jurgen/J.Boudrillard/J. Foster. La Posmodernidad. Kairos, Barcelona, 1986.

IZUZQUIZA, O. I. La sociedad sin hombres: Niklas Luhmann o la teoría como escándalo. Barcelona: Anthropos. 1990.

LUHMANN, Niklas . Sociedad y sistema: la ambición de la teoría. Barcelona: Paidós.1990.

-----. La sociedad de la sociedad. Herder España.2000.

MATURANA, Humberto y VARELA, Francisco. De máquinas y seres vivos: Autopoiesis: la organización de lo vivo. Santiago: Universitaria. 1995.

MOSQUERA, Orozco Jaime y MUÑOZ, Gaviria Diego. Una mirada teórica y metodológica a la obra de Niklas Luhmann: entre sistema y entorno. Revista Colombiana de Ciencias sociales. Vol 3, 2012.

RODRIGUEZ, Mansilla Darío y TORRES, Nafarrate Javier. Introducción a la teoría de la sociedad de la sociedad de Niklas Luhmann. Hder, Universidad Iberoamericana, 2009.

VARELA, Edgar El Poder Organizacional y sus Principales Ámbitos Discursivos en las ciencias del management. Coloquio de Epistemología. Florianópolis, Brasil,2014.

----. Managerialismo - culturas de empresa y emergencia del "hombre managerial". revista Fórum Doctoral número 6. enero - junio de 2015.

ZOLO, Danilo, "Function, Meaning, Complexity, The Epistemological Premises of Niklas Luhmann's 'Sociological Enlightenment', en Philosophical Social Sciences, núm. 16, 


\section{A BARREIRA ENTRE GAYS E MERCADO DE TRABALHO: UM ESTUDO SOBRE A DISCRIMINAÇÃO DE HOMENS GAYS NO SETOR DE TELECOMUNICAÇÕES}

Data de aceite: 11/03/2020

Data de submissão: 13/12/2019

Diogo Barros Azevedo

UEL - Universidade Estadual de Londrina Londrina - PR

https://orcid.org/0000-0002-0298-8839

Luiz Eduardo Pereira Batista UEL - Universidade Estadual de Londrina Londrina - PR

https://orcid.org/0000-0003-2604-1698

Luiz Bruno de Bom da Silveira UEL - Universidade Estadual de Londrina

Londrina - PR

https://orcid.org/0000-0003-3534-6856

RESUMO: O objetivo deste artigo foi o entender o contexto social que culmina na exclusão dos homens gays das áreas técnicas de empresas de telecomunicações. Para isso, os pesquisadores se utilizaram de uma pesquisa qualitativa, objetivando retratar parcialmente a realidade vivenciada por técnicos que desempenham essas funções. A coleta de dados se deu por meio de entrevistas com homens héteros que trabalham na área técnica no setor de telecomunicações. Os resultados nos mostram que os gays são tomados como femininos, culminando no posicionamento dessas pessoas na divisão sexual do trabalho. Desta forma, sua exclusão no setor técnico dessas organizações se dá por práticas preconceituosas baseadas nos estereótipos socialmente criados para os gays, dentro e fora da empresa, aceitas como normais e culturais, ou pior, descritas como normas de convivência.

PALAVRAS-CHAVE: Divisão Sexual do Trabalho. Masculinidade hegemônica. Homossexualidade.

THE BARRIER BETWEEN GAYS AND LABOR MARKET: A STUDY ON DISCRIMINATION OF GAY MEN IN THE TELECOMMUNICATION SECTOR

ABSTRACT: The purpose of this paper was to understand the social context that culminates in the exclusion of gay men from the technical areas of telecommunications companies. For this, the researchers used a qualitative research, aiming to partially portray the reality experienced by technicians who perform these functions. Data were collected through interviews with straight men working in the technical area in the telecommunications sector. The results show us that gays are taken as female, culminating in their positioning in the sexual division of labor. Thus, their exclusion in the technical sector of these organizations is due to prejudiced practices based on socially created stereotypes for gay people, inside and outside the company, accepted as normal and cultural, or worse, 
described as norms of coexistence.

KEYWORDS: Sexual Division of Labor. Hegemonic masculinity. Homosexuality.

\section{I INTRODUÇÃO}

Nas empresas, é tomada como verdade pelos gestores a "lógica burocrática", proposta por Weber (1999), que considera o ambiente organizacional neutro e impessoal. Trata-se, portanto, de uma ideia de separação entre a vida privada e pública, sob a qual as atitudes afetivas seriam desconsideradas, valorizando sempre a impessoalidade e a neutralidade. Para Prestes Motta (2001, p.102):

\footnotetext{
A sociedade moderna inclui em sua reprodução um conjunto de elementos e relações técnicas; vale dizer, um sistema técnico que implica a utilização técnica do homem. Nesse quadro o homem é submetido a um processo de racionalização do trabalho que se apresenta como científico e neutro.
}

Entretanto, essa lógica não traduz a realidade. O ambiente organizacional, assim como qualquer ambiente social, é construído a partir das relações sociais, implicando na criação de grupos e padrões que expõe os sujeitos à diversas formas de preconceitos e estereótipos. Dentre os padrões sociais historicamente rejeitados e discriminados na grande maioria das organizações, podemos destacar pessoas do sexo feminino, negras e homossexuais (RIBEIRO, 2017; SCOTT, 1995; LOPES, 2017; SOUZA, 2009; STANGOR, 2009).

Nestetrabalho, busca-se um foco nos homens gays, mais especificamente, aqueles que atuam profissionalmente nas áreas técnicas de serviços de telecomunicações, em que há uma inviabilidade gay, uma vez que, neste ambiente, comportamentos culturalmente entendidos como femininos não são bem-vindos, como veremos a seguir.

Através deste estudo, pretende-se alimentar a compreensão e a discussão a respeito das relações sociais no ambiente de trabalho sob uma perspectiva da sexualidade. Por meio de uma pesquisa qualitativa, espera-se ampliar a visão de como é a aceitação do gay em um ambiente técnico majoritariamente composto por homens cis héteros.

Para isso, primeiramente serão abordadas definições e ideias relacionadas ao preconceito, à discriminação e ao estereótipo. Após isso, alguns trabalhos relacionados à estigmatização dos (as) homossexuais serão citados e discutidos, a fim de trazer outras realidades vinculadas ao propósito desta pesquisa. Por fim, será apresentada a análise das entrevistas.

\section{I DISCRIMINAÇÃO, PRECONCEITO E ESTEREÓTIPO}

Stangor (2009) define o preconceito como uma atitude negativa em relação a um grupo ou membros de um grupo, relacionado à manutenção da identidade social e à competição entre grupos. Embora as pessoas ajam, às vezes, como indivíduos, 
com suas particularidades, elas o fazem como representantes dos grupos em que estão inseridas. Essa representação viva faz com que elas criem categorizações e preconceitos.

É por isso que os indivíduos tendem a demonstrar menos preconceito do que eles realmente possuem, especialmente quando o meio em que o indivíduo está inserido não o legitima (STANGOR, 2009). Quando o preconceito é legitimado pelo meio, ele é mais facilmente expressado, pois pode ser encoberto com desculpas que serão socialmente aceitas. E isso é muito perigoso, uma vez que, para Stangor (2009), essas ideias e crenças que são criadas sobre outros grupos influenciam poderosamente a manutenção da identidade dos grupos e da competição entre eles, o que pode ser altamente nocivo.

É possível contextualizar isso com a realidade política e social brasileira. Enquanto no passado algumas pessoas escondiam seu preconceito, devido ao medo de retaliação pública e a não aceitação social de suas atitudes, atualmente muitas delas expressam livremente, pois existem várias lideranças políticas e sociais, também instituições (incluindo o Estado, em alguns aspectos), naturalizando o preconceito e acabando por legitimá-los.

A "naturalização" de determinados aspectos e preconceitos, como reforça Aguiar (2007), resultam em subordinação - como no caso das mulheres, dos negros e dos gays -, e ainda criam, segundo Stangor (2009) uma espécie de norma social que leva à discriminação, ou seja, à ação de diferenciar ou discernir as pessoas pela cor da sua pele, seu gênero e sexualidade, por exemplo.

Butler (2003, p.191) defende que a fronteira entre o "interno" e o "externo" foi erigida como meio de exclusão e dominação, fazendo com que "[...] dessa forma o Outro "vira merda". Baseada em Kristeva, Butler (2003) afirma que "o Outro", esse ser abjeto que não pode ser confundido com o meu eu, deve ser expelido, posto à distância, diferenciado de mim, para que eu possa ser um sujeito coerente.

É neste movimento que são criados os estereótipos que, segundo Stangor (2009), pode ser entendido como "as figuras" ou traços que vêm à mente de um indivíduo a respeito de outro, quando ele pensa a respeito do grupo ao qual este outro pertence. Como exemplo disso, pode-se citar a travesti, que é automaticamente levada à condição de prostituta, mesmo que isso seja impreciso e injusto em muitos casos.

Para Bhabha (1998) o estereótipo é uma contradição: ao mesmo tempo em que há uma recusa, há um encantamento, uma espécie de desejo sobre aquilo que é negado, envolto a curiosidade. Isso, o autor reconhece como fetiche, "uma forma nãorepressiva de saber que dá margem à possibilidade de se abraçar simultaneamente duas crenças contraditórias, uma oficial e uma secreta" (BHABHA, 1998, p. 124).

Indivíduos expostos a experimentar com frequência a discriminação proveniente da criação de estereótipos e do preconceito, estão muito mais sujeitos a vários problemas psicológicos e perdem a felicidade e satisfação por viver (STANGOR, 2009). É algo muito comum notícias sobre pessoas, inclusive jovens, crianças e adolescentes, 
que tiraram suas próprias vidas por não suportar mais o fardo do preconceito e da discriminação. Além disso, esses indivíduos podem se isolar e comprometer muito seus sonhos e expectativas.

Aguiar (2007) diz que os estereótipos muitas vezes são escancarados para a perpetuação o que explica muito o fato de a sociedade brasileira permanecer tão preconceituosa nos dias atuais e não abandonar os estereótipos criados, até porque estes muitas vezes se manifestam e se perpetuam inconscientemente. Nas novelas, histórias e filmes as empregadas domésticas são geralmente negras e homens gays são sempre afeminados e engraçados. Esses personagens carregam consigo um mundo de estereótipos que são reafirmados nos indivíduos pela repetição e naturalização.

\section{I ESTIGMATIZAÇÃO DO GAY}

O tratamento hostil contra gays recebe diversos nomes, tais como heterossexismo (MORIN; GARFINKLE, 1978) e homofobia (SMITH, 1971). No entanto, ambos são sustentados pelo estigma, segundo Herek (1991). Percebe-se uma dicotomia no tratamento e consequentemente na criação de estereótipos em relação aos homossexuais, como bom e ruim ou favorável e não favorável. Esse dualismo é o simples fruto de uma sociedade branca, machista e heteronormativa. De um lado, totalmente positivos e perfeitos estão os heterossexuais e os casais tradicionais naturais e universais. Do outro, os gays - simples desvios do padrão dominante (LOPES, 2017).

Assim como membros de outras minorias sociais, os gays enfrentam numerosos e diversos desafios psicológicos e psicossociais em consequência do tratamento hostil da sociedade. Por esse motivo, muitos deles escolhem viver contidos, escondendo sua sexualidade ou até mesmo se passando por heterossexuais, como pode ser visto nos estudos desenvolvidos no Brasil pelo Center for Talent Innovation (2016) e nos Estados Unidos por Ragins e Cornwell (2001).

De acordo com uma pesquisa divulgada no final de janeiro de 2016 pelo Center for Talent Innovation (2016), 61\% dos funcionários LGBT no Brasil afirmam esconder sua sexualidade para outros funcionários, incluindo seus gestores, número bem superior ao divulgado para países como Estados Unidos (30\%) e Inglaterra (28\%), o que mostra a gravidade do problema brasileiro.

Herek (1991) afirma que o resultado da ocultação da orientação sexual por parte dos gays, gera uma profunda e dolorosa discrepância entre as identidades pública e privada do indivíduo. A não aceitação de suas reais identidades, os tornam inautênticos, como se estivessem vivendo uma mentira, sob qual a verdade de suas vidas, seu íntimo mais profundo, que é sua sexualidade, não é aceita.

Outra consequência é o distanciamento que os gays acabam fazendo de seus familiares e amigos, mesmos próximos, a fim de não revelar sua sexualidade, ou quando eles mantêm apenas um contato superficial como uma espécie de autodefesa 
(HEREK, 1991). Caso o gay tente deixar a casa em que vive devido à rejeição de sua sexualidade, por exemplo, ele pode tornar tanto sua própria vida, como a de quem ele vive insustentável, devido à interdependência econômica dos indivíduos (MARSIAJ, 2003), o que mostra também, uma interseccionalidade de classe social, uma vez que o gay financeiramente independente pode "sustentar" sua sexualidade, enquanto o gay pobre precisa escondê-la e viver de acordo com o padrão heteronormativo.

Herek (1991) ressalta os riscos para os homossexuais que decidem "sair do armário". Uma vez mostrando a todos sua sexualidade, eles podem ser rejeitados (inclusive por pessoas que são importantes para ele), além de se exporem à violência física e sexual (especialmente os gays mais pobres) e a muitos problemas psicológicos (DION, 1986; BIRT; DION, 1987, HEREK, 1991). Também existem efeitos ou problemas comportamentais e corpóreos, como distúrbios do sono, dores de cabeça, diarreia, choro incontrolável, agitação e uso de drogas (JANOFF-BULMAN; FRIEZE, 1983).

Motivos não faltam para os gays não saírem do armário. No que tange o trabalho, a situação tona-se ainda mais difícil, uma vez que a discriminação, muitas vezes, barra sua contratação e, quando na empresa, sua promoção, pelo simples fato de ter sua sexualidade assumida. Pesquisas realizadas em organizações mostraram que o preconceito contra gays no ambiente laboral são de dois tipos: 1) a formal (HEBL et al., 2002) ou de acesso (GREENHAUS; PARASURAMAN; WORMLEY, 1990): que se manifesta por meio das regras, normas ou padrões da empresa ao contratar ou ao promover funcionários, não permitindo a entrada de membros de grupos diferentes na organização; 2) a interpessoal ((HEBL et al., 2002) ou no tratamento (GREENHAUS; PARASURAMAN; WORMLEY, 1990): não se manifesta tão descaradamente, mas ocorre quando os membros grupos minoritários, ainda que estejam sob critério legítimo, não recebam as mesmas recompensas, recursos ou oportunidades que aqueles que estão nos grupos dominantes recebem.

No Brasil, o trabalho de Souza e Garcia (2010) demonstram claramente a discriminação de duas formas, que eles chamam de direta e indireta, no setor bancário. É por isso que, segundo Ragins e Cornwell (2001) e Herek (1998), quanto mais discriminação e preconceito no ambiente de trabalho, maior a chance de que os gays ali presentes ocultem sua sexualidade em comparação com ambientes onde outros LGBT's não percebem tanta discriminação e preconceito.

Souza, Bianco e Silva (2016) em seu trabalho com homossexuais do setor bancário brasileiro, trouxeram observações muito importantes sobre o tema. Eles observaram que a revelação da orientação sexual do indivíduo tem relação com o grau de satisfação do trabalho e que as diferenças individuais tem uma relação íntima com a maneira e a possibilidade de se assumirem no ambiente de trabalho. Verificaram também que o apoio da organização por meio de políticas e normas que evitem a discriminação, atuam positivamente para que estes homossexuais assumam sua sexualidade.

Enquanto isso não é uma prática comum, os gays, entendendo os conflitos que 
podem passar, buscam estratégias para sobreviver no mercado de trabalho ocultando sua sexualidade, como: falar mal de gays, firmar a voz e alterar sua maneira de andar, trocar pronomes masculinos por femininos quando relatavam experiências afetivas, ter atitudes heteronormativas, vestir roupas masculinas, agir discretamente, omitir sua sexualidade para familiares e pessoas com quem saíam, manter relações sexuais com mulheres, chegando ao ponto de noivar, se manter aparentemente "assexuado".

\section{I ASPECTOS METODOLÓGICOS}

Esta pesquisa se utilizou de uma metodologia qualitativa para buscar a compreensão sobre o fenômeno social aqui abordado com o intuito de elevar a "relevância do aspecto subjetivo da ação social, face à configuração das estruturas societais" (HAGUETTE, 2003, p. 63), visto que "sujeitos com suas opiniões sobre um determinado fenômeno, traduzem parte de sua realidade" (FLICK, 2004, p. 42).

Para as entrevistas, foram selecionados e convidados três funcionários héteros do sexo masculino de empresas privadas prestadoras de serviço na área técnica de telecomunicações da cidade de Londrina-PR. Para tanto, tomamos o cuidado de que a conversa não fosse ouvida por outras pessoas, a fim de evitar qualquer desconforto ou receio ao entrevistado. Torna-se imprescindível salientar que, embora o foco desta pesquisa seja mostrar a estigmatização dos gays e a não aceitação destes na área em questão, não foi possível encontrar técnicos gays que pudessem contar sobre sua própria experiência de estigmatizado. Foi utilizado um roteiro de entrevistas que permitiu a flexibilidade ao entrevistador.

\section{I GAY, O SEU LUGAR NÃO É AQUI}

Histórica e lentamente ocorreram inscrições sociais que ditaram a subordinação dos homossexuais aos heterossexuais. Assim, dentro e fora das organizações, os homossexuais foram marginalizados e oprimidos, sendo direcionados a determinadas funções (MAGALHÃES; SARAIVA, 2018). Diversos trechos ditos pelos entrevistados, ilustram como os gays, por considerarem portadores de características femininas, não é aceito em determinados setores, como no de técnico, uma vez que eles não possuem as características físicas e psicológicas adequadas para o cargo, como podemos ver abaixo nas falas abaixo:

(F01) Cara é um trabalho bem complicado né, o negócio assim que depende muito de esforço... É... não pode ter nojinho, né? Não pode ter, sabe? Calor. É um trampo complicado cara, assim cê tem que ter paciência, cê tem que ter resiliência, porque cê toma muita porrada, toma de todos os lados, você tem que ser forte cara.

(F02) Ah, tipo subir em poste, eu nunca vi uma mulher trepada num poste, né? Mas acho que por ser assim o trabalho de você ir nas casas, pra mulher ficaria mais constrangido né? Eu acho. Você vai na intimidade de cada cliente né, você entra lá e tem que procurar dentro do forro... os defeitos... entendeu? [...] muito indelicado eu acho, seria mais uma profissão indelicada. 
(F03) O cara tem que ter força de vontade mesmo. E bom, ele tem que ter uma condição física, sim, não tem como fugir disso, né? Nessa área ainda mais que envolve, questões que, às vezes, envolvem algum risco, tipo dirigir, subir em postes, subir num telhado, então a pessoal precisa mesmo ter uma condição física. (F04) Rapaz, eu acho que envolve também a questão do preconceito, né? Que tem o preconceito, sim. de mulher e homossexual nessa área que tem, digamos entre aspas, mais "peão", né? E também, eu acho, acredito que é... porque os gays que conheci lá, é... trabalhavam no administrativo ou na área comercial, né? E eles tinham uma desenvoltura melhor nessas áreas, eu acredito que a desenvoltura deles é pra essa área, não menosprezando que eles não tenham capacidade técnica, mas eu acho que não tem interesse deles na área técnica, entendeu? Agora na área comercial, eu acho que eles têm uma desenvoltura melhor e mulher também, eu acredito que tem, porque é mais minuciosa, né, então acredito que na área comercial, na área de atendimento, pelo fato delas ter mais paciência também e na área de atendimentos aos técnicos que exige também uma paciência, então acho que a mulher teria mais paciência, e... então elas conseguiriam desenvolver um trabalho melhor nessas áreas.

Percebe-se nas falas que eles entendem como inerente ao homem trabalhos que exigem força e resiliência, excluindo os gays e as mulheres destas características e possibilidades. Desta forma, ocorre uma divisão sexual do trabalho, que tem como seus princípios organizadores a separação - homens fazem o trabalho pesado e indelicado, enquanto as mulheres e gays os que se pode "ter nojinho", ser fraca(o), inflexível e delicada(o) - e a hierarquização - em que "um trabalho do homem 'vale' mais do que um trabalho de mulher" (KERGOAT, 2003, p.56). No que tange ao princípio de hierarquização, são entendidas como trabalho de gays e mulheres às que se relacionam ao cuidado, como maquiadoras/maquiadores e cabeleireiros, funções que, na maioria das vezes, não têm o mesmo reconhecimento social daquelas destinadas "naturalmente" aos homens heterossexuais.

(F05) Então é questão de ser como técnico, né? Agora se for uma empresa, assim, só de humanas, foda-se! O cara quer vir como drag... [...] minha esposa trabalhou numa que tinha "um" drag lá [...], mas era um salão de beleza, de fazer unha, cabelo, etc. [...] Agora numa empresa como técnico, pô, você tem que ser mais formal.

É interessante como uma mesma palavra tem significados diferentes quando se refere aos homens ou às mulheres ou gays. Quando um dos entrevistados (F01) cita a paciência como uma das características masculinas necessárias ao cargo, ele está se referindo à capacidade de tolerar dissabores sem se abalar, tanto que complementa com a palavra resiliência. No entanto, em outro trecho (F04), o entrevistado, ao citar a mesma palavra, a faz a interligando agora como uma característica feminina, pois pode-se subentende-la como calma para tratar com as pessoas e com o trabalho minucioso.

Nota-se claramente nesses trechos a exposição do estereótipo definido por Stangor (2009), realçado quando o entrevistado cita as características que ele imagina não encontrar em uma mulher e nos gays que são necessárias ao trabalho. Notamos 
nas falas que aos gays masculinos são dadas características femininas, enquanto às lésbicas, masculinas, como se elas e eles fossem caricaturas de mulheres e homens, descaracterizando suas dimensões humanas (IRIGARAY; SARAIVA; CARRIERI, 2010).

A que mais chama a atenção é a força, que um dos entrevistados faz questão de justificar dizendo que para aquele trabalho "se leva muita porrada" (F01). Não se trata, no entanto, somente da força física, mas a uma força psicológica que, como podemos notar nas falas dos entrevistados, está ligada "aos hormônios" (F06) que afeta tanto mulheres quanto gays. É por isso que afirma-se que o homem gay, na verdade não é homem. Homem de verdade é o hétero, que estaria preparado para maiores desafios e cobranças, tanto fisicamente ("trepar num poste"), quanto psicologicamente (para "levar porrada" e não "entrar em depressão").

(F06) [...] homem, homem! Homem! Tá? Não homem gay, "Homem Homem"
aguenta mais a porrada, psicologicamente, do que a mulher, mulher entra em
depressão, gay entra em depressão, é alguma coisa relacionada a hormônio, sei lá,
o que que é relacionada na cabeça da pessoa, mas eles entram, tendem a entrar
em depressão mais fácil, eu não sei o porquê, né? Eu acho que para atender cliente
você tem que ter um colhão maior.

(F07) [...] e também é questão genética também influência a pessoa a não querer pegar esse serviço, sujo, serviço pesado, então ninguém quer fazer esse serviço sujo e pesado, só... homem que faz. Igual, todas empresas que eu fui, só homem faz serviço pesado e é caso raro quando você vê uma mulher, tá? É, geralmente é como aquelas, desculpa a palavra, sapatona, sapatona [...] às vezes aguenta igual homem, infelizmente né? Não querendo ser preconceituoso né? Não sendo machista, mas é questão de genética, mulher não tem mais força que o homem. não tem como, o homem tem mais músculo que a mulher e enfim... tá? Isso aí não tem como mudar, é difícil. Então é mais por causa de genética cara [...].

A submissão dos gays e das mulheres é evidenciada pela sua castração simbólica quando o entrevistado faz referência ao colhão, ou seja, testículo. Há, nestes trechos, confusão no que se refere ao determinismo biológico e social, uma vez que ao mesmo tempo em que justifica sua posição pelas razões biológicas ("hormônios masculinos e femininos"), é possível ver nas falas que as lésbicas ("sapatonas"), que são biologicamente mulheres, são consideradas capazes de realizar as funções primeiramente destinadas aos homens de acordo com os padrões dominantes socialmente.

É devido a isso que muitos gays escondem sua homossexualidade quando trabalham na área técnica. Um dos entrevistados citou um colega de trabalho que após ter sua homossexualidade revelada se viu obrigado a se afastar dos colegas de trabalho, alterar seus comportamentos e relações, em concordância aos achados de Ragins e Cornwell (2001).

(F08) [...] tinha um, que era o [NOME] que a gente não sabia até certo momento, aí começou aparecer um cara lá... e a gente ficou desconfiado. Depois ele assumiu, mas depois saiu. [...] Depois que descobriu que o cara era gay, o cara saiu fora. 
(F09) [...] teve um rapaz lá que surpreendeu a gente, sabe? Porque a gente achava que ele era... né? Aí do nada ele apareceu que estava namorando e tal. Ai quando foi ver ele tava namorando com outro homem [risos], casou com o cara. Ai depois disso ele começou a se afastar mais, não queria ficar muito assim... do lado dos... Por que acho que o marido dele, sei lá, tinha ciúmes. Aí ele não podia participar de nada.

O não participar de nada inclui as piadas comuns no ambiente de trabalho e no grupo de Whatsapp, que na maior parte das vezes se refere à sexualidade homossexual. Como disse Islandia: "Até mesmo eu faço brincadeira de boiolagem lá com o pessoal lá [...] Mas então, enfim, eu acho que se tivesse um cara gay ali, não sei como seria, não". Piadas contra gays são consideradas normais e, portanto, parte do dia a dia dos técnicos nesta organização, como podemos ver nas falas de todos os entevistados.

(F10) Muita boioladagem. Um fica zoando o outro por causa de viadagem, pra caraio. Mas é viadagem, muita viadagem pra caraio. Ninguém é gay. mas é muita viadagem, cara. [...] Gira em torno mais da viadagem, cara. Esse negócio de ficar zoando o outro que um é viado, o outro num é viado... Não sei o que que é essa pira aí. É engraçado. Aí todo mundo da risada, e fica nisso [...].

(F11) Sim, tem, às vezes, tem sim, um tipo de brincadeira é... mais voltado assim, a gay. [...] Mas o fato de brincadeira com homossexual às vezes tem, sim, uma piadinha ou outra com outros.

(F12) É, é de tudo. É assim... por exemplo, todo mundo fala "ah seu veado". [...] Que não tem mulher eu acho, né? Aí quando a faxineira está lá dá uma moderada, né?

O que se constata nestas falas são características descritas por Stangor (2009) a respeito do preconceito: práticas preconceituosas são limitadas em ambientes em que não são toleradas e, em contrapartida, se tornam naturais e até esperadas quando legitimadas pelo meio. As piadas contra homossexuais são, segundo Irigaray, Saraiva e Carrieri (2010, p.902), "uma forma de discriminação por orientação sexual no ambiente de trabalho", se constituindo uma forma sutil de controle e de diferenciação - são os outros e não nós. Naquele ambiente, as piadas baseadas nos estereótipos homossexuais atuam como norma social, sendo considerada estranha a pessoa que não agir desta forma. É assim que, mesmo para as relações interpessoais, os gays são excluídos nestes ambientes, como podemos ver nas falas a seguir:

(F13) Ah sim, se o pessoal brincasse muito perto dele assim, acredito que uma hora ele não ia..., por mais que o cara, às vezes releve ou leve numa boa a brincadeira, uma hora ele não iria aguentar, ele ia achar ruim, sim.

(F14) [...] já teve cara lá, ele não era digamos, assumido, mas ele trabalhava lá com a gente e eu pude presenciar isso: tipo, longe dele tinha as brincadeiras, próximo a ele não tinha as brincadeiras, né? Tinha um ou outro que deixava escapar assim, 
(F15) [...] igual um dia que fui sair com um amigo meu, daí ele levou o amigo dele, que era amigo da mulher dele, que era gay, né? Daqueles bem assumidaço, sabe? Só que daí a gente, conversando com ele eu falo: "oh, seu viado, para com isso". Daí, depois, eu lembrava assim, né? "ai, o cara tá do lado aqui", né? Aí, ele ficava meio assim... o clima, né... Aí, a mesma coisa aconteceria na empresa, né? Se você, se... o cara às vezes não ia gostar, né? Aí, a gente tinha que parar com as brincadeiras, né?

Enquanto dois dos entrevistados abaixaram um pouco a voz e se mostraram até "intrigados" com a situação em que um possível colega gay estaria sendo exposto, um deles minimizou as piadas e a reação daqueles que sofrem com o preconceito, especialmente aquele camuflado em brincadeiras e piadas, também sexualizando e erotizando o homossexual e classificando-o como alguém que "levaria a sério" as brincadeiras. A intenção ao erotizar o homem gay, é o colocar como uma figura pervertida, em equivalência às palavras de Lopes (2017).

(F16) Eu acho que ia ter um preconceito ali, acho que os cara ia ficar meio receoso de dar uma viadagem. [...] O homem é foda: quando o cara sabe que o cara é gay, o cara não vai mexer com o cara porque sabe que o cara vai... tipo assim, cê faz uma piadinha lá de gay, aí cê fala, ah pega no meu, pega no seu, não sei o que, não sei o que lá, aí você sabe que o viado vai pegar, você sabe que o cara vai te pegar. Quando é homem o cara não pega, o cara só vai, tipo, coca-cola, só vai agitar ali, né? Agora, quando o cara é gay, você vai pegar. Pega no meu, o cara vai pegar, pô, não é? Não é verdade? Você sabe que o homem gay, o cara é safadão demais, o homem já é safado por natureza, imagina gay cara, com um monte de homem perto? Então, a gente fica meio... [...] Aí é foda! Hoje em dia tá foda, cara, você não pode zoar com mais nada.

Rir do Outro também pode revelar a contradição descrita por Bhabha (1998), em que os entrevistados, ao mesmo tempo em que demonstram repulsa pela homossexualidade, demonstram fascínio pelo gay e uma certa curiosidade. $\mathrm{O}$ fato de achar "engraçadinho", querer se "aproximar mais" e achar "legal até", revelam uma mistura de confusão e desejo em querer ver a homossexualidade, como alguém vê uma obra de arte, como expressa na seguinte fala:

(F17) [...] eu acho até engraçado quando tem gay eu acho que eu quero me aproximar mais ainda. Não foi por querer o cara, né? É mais por questão, assim, acho engraçadinho, sabe? O cara ficar falando com uma voz fininha e tal $[\ldots]$.

É perceptível a negatividade atribuída à figura do gay afeminado, comparando-o com um funcionário desleixado e o rebaixando ao status de piada. A não aceitação das travestis é ainda mais intensa, devido à sua aparência e modo de vestir. Ressaltase aqui, a responsabilidade lançada à empresa, como culpada por não contratar sujeitos afeminados ou travestis, isso seria uma demonstração de como a visão deste 
entrevistado enxerga a discriminação direta proposta por Souza e Garcia (2010) e a discriminação formal, de Hebl et al (2002).

(F18) Mas não é que você é preconceituoso, é só questão de carisma e de vendas Igual, você não vai conseguir vender seu produto, se num... como você vai falar bem dos seu produto, se o seu produto que tá alí tá mal. desleixado... Enfim, igual cheiro: cê vai comprar alguma coisa se o cara tá parecendo um mendingo? Entendeu agora? [...] cara é macho, sexo masculino, usando cabelão solto, assim. maquiagem, pó e com uniforme da [MARCA] é escro... é estranho, não é que é escroto. É estranho. E para entrar na casa da pessoa, a pessoa vai falar: "que, porra é essa? É brincadeira?". Vai achar que é brincadeira. Vai achar que o cara tá de palhaçada com ele, com a cara dele.

Esses comportamentos e pensamentos restringem o gay, especialmente 0 afeminado, e a travesti, a atividades em que ele esteja escondido, onde o mundo real não poderia vê-lo. As possibilidades de trabalho que são oferecidas a essas pessoas, que estão presas em uma espécie de "quarto escuro", são como mínimas frestas, que possibilitam a elas apenas observar a vida com enorme esforço e angústia.

(F19) [A empresa] teria preconceito, acredito que sim. [...] por alguns clientes teriam uma postura diferente também [...] Então, você não sabe mais ou menos como cada uma vai reagir, né? Mas acredito que alguns clientes teriam preconceito e teriam preconceitos já lá na empresa, sim [...] por questões de aparência junto ao cliente. Infelizmente a gente vive numa sociedade que às vezes é um pouco preconceituosa. Um pouco não, muito preconceituosa, machista, então eu acredito que para a pessoa em si evitar um problema e manter o seu trabalho, as vezes, ela deveria também evitar no ambiente do trabalho isso, infelizmente ela deveria evitar.

(F20) Do jeito que o pessoal é, eu acho que não deixaria nem entrar [...]. Não deixaria. Eu acho que as pessoas são muito, não é nem preconceituosas, eu acho que é cultural mesmo, né? Essas coisas aí, as pessoas não deixam, ainda mais "Ai! Meu filho pequeno aqui em casa, vai ver um cara desse aqui?", não vai, não deixa, né? Nem ferrando [...] acho que não iria pegar bem pra empresa.

Já haveria, portanto, um preconceito formal (HEBL et al., 2002) ou de acesso (GREENHAUS; PARASURAMAN; WORMLEY, 1990), barrando a entrada de gays nestas organizações. Neste caso, os entrevistados creditam essa barreira à aparência física dessas pessoas, como se todos eles se comportassem ou se vestissem da mesma forma e, pior ainda, como se esta forma não se adequasse ao que é pedido aos funcionários da empresa que está conforme os ditames da cultura aceita pela sociedade ao seu redor. É notável, portanto, que não existem barreiras aceitáveis para a presença de homens gays desempenhando tais funções. O que nos deparamos foi com atitudes preconceituosas travestidas de "costumes" e "cultura".

\section{I REFLEXÕES FINAIS}

Este artigo teve por objetivo entender as relações que culminam na exclusão do homem gay do mercado de trabalho no setor técnico de empresas na área de 
telecomunicações. Por meio das análises feitas sobre as falas dos entrevistados foi possível verificar que, embora as empresas tenham em seu corpo funcionários gays, estes são realmente excluídos das áreas técnicas, mais especificamente, das funções de técnicos ou instaladores.

Essa exclusão se dá, ao que parece, por práticas preconceituosas e discriminatórias dentro e fora da empresa, impregnadas e aceitas como normais e culturais, ou pior, descritas como normas de convivência. Atitudes como piadas machistas e homofóbicas são parte do dia a dia desses trabalhadores, estigmatizando o estereótipo mentalmente fixo do homem gay de diversas formas negativas e afastando estes sujeitos da possibilidade de exercer tais atividades.

Embora os entrevistados descrevam características para execução de trabalhos nessa áreas que sejam possíveis tanto para gays quanto para mulheres, eles mesmos acreditam que estes não seriam capazes de exercer tais funções na prática. Isso se dá por uma separação dicotômica entre as características fornecidas, que são, pelo senso comum, designadas aos homens, e as características que são destinadas às mulheres e por consequência aos homens gays, que devido ao não entendimento do universo possível de masculinidades e feminilidades, acabam recebendo muitas consequências discriminatórias e exclusivas da feminilidade.

Algo que deve ser explorado, é que os trabalhadores entrevistados não demonstraram, na maior parte do tempo, perceber como o homossexual é excluído dessa área, encarando a ausência de homossexuais como algo natural, como falta até de interesse deles - falta de aptidão biológica. As atitudes preconceituosas vivenciadas no dia a dia, que propagam e perpetuam a exclusão dos gays, são vistas como normas de convívio social, não havendo nenhum tipo de remorso ou pesar sobre qualquer atitude.

As práticas discriminatórias, tratadas como normas e parte da cultura e que resultam na exclusão e marginalização dos gays e também das mulheres, como é o caso tratado neste estudo é baseada em valores e crenças pré-estabelecidos, compartilhados pelos indivíduos dentro e fora da organização de trabalho e que, ao que se pôde notar pelos enunciados, são pautados divisão sexual do trabalho (KERGOAT, 2003).

Também não foram notadas atitudes e políticas das empresas que pudessem buscar a redução das práticas discriminatórias ou que auxiliassem para a correção da visão distorcida e do estereótipo criado do homem gay, que pudesse mostrar que esse ambiente pode e deve se tornar oportunidade para todos os que queiram desempenhar essas funções, não somente para um grupo de pessoas que o dominaram historicamente. Essa permissividade e dificuldade da gestão em lidar com problemas de homofobia também foi verificada por Diniz et al. (2013) e deve ser verificada em estudos futuros.

Diante disso, devemos incluir a necessidade de políticas públicas junto às ações esperadas pelas empresas privadas para correção dos desvios observados neste 
trabalho. Não é passível de aceitação que nenhum ambiente de trabalho seja negado aos gays e outras minorias sociais devido a características divergentes ao padrão de aceitação dominante: homem, hétero, branco, cristão. Estudos que vinculem as práticas públicas e as ações dentro das organizações privadas também são esperados, assim como estudos que revelem a ação heteronormativa em outros setores da economia.

\section{REFERÊNCIAS}

AGUIAR, M. M. A construção das hierarquias sociais: classe, raça, gênero e etnicidade. Cadernos de Pesquisa do CDHIS, Uberlândia, v.1, n.37, p.83-88, dez. 2007.

BHABHA, H. K. O local da cultura. Belo Horizonte: Editora da UFMG, 1998.

BIRT, C. M.; DION, K. L. Relative deprivation theory and responses to discrimination in a gay male and lesbian sample. British Journal of Social Psychology, v.26, p.139-145, 1987.

BUTLER, J.P. Problemas de gênero: feminismo e subversão da identidade. Rio de Janeiro: Civilização Brasileira, 2003.

CENTER FOR TALENT INNOVATION. Out in the World: Securing LGBT Rights in the Global Marketplace. Center for Talent Innovation. 2016. Disponível em: < <http://www.talentinnovation.org/ publication.cfm?publication=1510 $>$. Acesso em: 27 jan. 2019.

DINIZ, A. P. R; CARRIERI, A. P.; GANDRA, G.; BICALHO, R. A. Políticas de diversidade nas organizações: as relações de trabalho comentadas por trabalhadores homossexuais. Revista Economia e Gestão, v. 13, n. 31, p. 93-114, jan/abr 2013.

DION, K. L. Responses to perceived discrimination and relative deprivation. In J.M. Olson, C.P. Herman, \& M.P. Zanna (Eds.). Relative deprivation and social comparison: The Ontario Symposium. Hillsdale, NJ: Lawrence Erlbaum. 1986.

FLICK, U. Uma introdução a pesquisa qualitativa. Porto Alegre: Bookman, 2004.

GREENHAUS, J. H.; PARASURAMAN, S.; WORMLEY, W. M. Effects of race on organizational experiences, job performance evaluations, and career outcomes. Academy of Management Journal, Briarcliff Manor, v.33, n.1, p.64-86, mar. 1990.

HAGUETTE, T. M. F. Metodologias qualitativas na sociologia. 9 Ed. Petrópolis: Vozes, 2003.

HEBL, M. R.; FOSTER, J. B.; MANNIX, L. M.; DOVIDIO, J. F. Formal and interpersonal discrimination: a field study of bias toward homosexual applicants. Society for Personality and Social Psychology, Washington, v. 28, n. 6, p. 815-825, jun. 2002.

HEREK, G. M. Stigma, prejudice, and violence against lesbians and gay men. In: GONSIOREK, J. C.; WEINRICH, J. D. Homosexuality: research implications for public policy. Newbury Park: Sage, 1991.

HEREK, G. M. Psychological perspective on lesbian and gay issues: stigma and sexual orientation. Newbury Park: Sage, 1998.

IRIGARAY, H.A.R.; SARAIVA, L.A.S.; CARRIERI, A.P. Humor e discriminação por orientação sexual no ambiente organizacional. RAC, Curitiba, v.14, n.5, art.7, p.890-906, Set./Out. 2010.

JANOFF-BULMAN, R., \& FRIEZE, I. H. (Eds.). Reactions to victimization [Special issue]. Journal of Social Issues, v.39, n.2. 1983. 
KERGOAT, D. Divisão sexual do trabalho e relações de sexo. In: EMÍLIO, M; TEIXEIRA, M.; NOBRE, M.; GODINHO, T. (Org.). Trabalho e cidadania ativa para mulheres: desafios para as políticas públicas. São Paulo: Coordenadoria Especial da Mulher, 2003.

LOPES, O. G. Gays afeminados ou poluição homoerótica. Periódicus, Salvador, v.1, n.7, p.405-422, maio/out. 2017.

MAGALHÃES, A. F., SARAIVA, L. A. S. Contradições entre essência e aparência nos processos de empoderamento de gays em organizações de trabalho. Revista Gestão e Planejamento, Salvador, v.19, p. 159-176, jan/dez. 2018.

MARSIAJ, J. P. P. Gays ricos e bichas pobres: desenvolvimento, desigualdade econômica e homossexualidade no Brasil. Cadernos AEL, Campinas v.10, n.18/19, p.129-149, 2003.

MORIN, S. F.; GARFINKLE, E.M. Male homophobia. Journal of Social Issues, v.34, n.1, p.29-47, 1978.

PRESTES MOTTA, F.C. Teoria das organizações: evolução e crítica. 2. ed. revista e ampliada. São Paulo: Pioneira Thomson Learning, 2001.

RAGINS, B. R.; CORNWELL, J. M. Pink triangles: antecedents and consequences of perceived workplace discrimination against gay and lesbian employees. Journal of Applied Psychology, Washington, v. 86, n. 6, p. 1244-1261, dez. 2001.

RIBEIRO, D. O que é: lugar de fala? Belo Horizonte: Letramento, 2017.

SCOTT, J. Gênero: uma categoria útil de análise histórica. Educação \& Realidade, v.20, n.2, p.71-99, Jul./Dez. 1995.

SMITH, K. T. Homophobia: A tentative personality profile. Psychological Reports, v.29, n.3, p.10911094, Dez. 1971.

SOUZA, E. M. de; BIANCO, F. B; SILVA, O. M. S. Análise arqueológica das estratégias utilizadas por homossexuais no trabalho bancário. Farol: Revista de Estudos Organizacionais e Sociedade, Belo Horizonte, v. 3, n. 6, p. 13-65, abr. 2016.

SOUZA, E. M. de; GARCIA, A. Sexualidade e trabalho: estudo sobre a discriminação de homossexuais masculinos no setor bancário. RAP: Revista de Administração Pública, Rio de Janeiro, v.44, n.6, p. 1353-1377, nov/dez. 2010.

SOUZA, J. Ralé brasileira: quem é e como vive. Belo Horizonte: Editora UFMG, 2009.

STANGOR, C. The study of stereotyping prejudice and discrimination within social psychology: a quick history of theory and research. In: NELSON, T.D. (Edit.) Handbook of prejudice, stereotyping and discrimination. New York, NY, US: Hove, Psychology Press, 2009.

WEBER, M. Economia e sociedade: fundamentos da sociologia compreensiva. Brasília: UnB, 1999. v. 2. 


\section{O TRABALHO ESCRAVO CONTEMPORÂNEO COMO PRÁTICA DE GESTÃO NO BRASIL A PARTIR DA ANÁLISE DO CONTEXTO REGULATÓRIO}

Data de aceite: 11/03/2020

Herena Neves Maues Correa de Melo Promotora de Justiça do Ministério Publico do Estado do Pará Doutora em Administração- Universidade da Amazônia

Doutoranda em Desenvolvimento do Trópico Unido - UFPA

Mestra em Direitos Humanos - UFPA

Reginaldo da Motta Correa de Melo Junior Mestrando em Administração- UNAMA

Advogado Administrador

Luciana Rodrigues Ferreira Doutora em Educação UFSCAR

Professora do PPAD - Universidade da Amazônia Coordenadora do PPGC - UNAMA

RESUMO: A escravidão persiste em escala global na forma de relações indecentes de trabalho, fundada na exploração econômica. O trabalho pretende discutir a escravidão contemporânea brasileira a partir da teoria da captura regulatória, objetivando demonstrar que por se incluir na economia global, tal prática relaciona de forma complexa as corporações e o Estado. Neste sentido, imprescindível analisar, sob o olhar da gestão pública e da regulação, considerando inclusive o percurso de aprovação da Emenda Constitucionl n. 81/2014, que modificou o Art.243 da CF/88. Segundo a Organização Internacional do Trabalho (OIT, 2009), a escravidão contemporânea é parte da economia mundial e sustenta a produção de uma gama de produtos. Raras empresas, governos ou organizações não governamentais (ONGs) se engajam ou reconhecem a problemática do trabalho escravo contemporâneo como uma situação central, mas tão somente como uma prática periférica, sintomática, ou mesmo entendido como metáfora (BALES, 2004; SAKAMOTO, 2008). Por outro lado, o debate também é marginal nas ciências sociais (BALES, 2004), sendo praticamente ignorado no campo da gestão Pública (COOKE, 2003; CRANE, 2013). Busca-se a contribuição científica ao campo da gestão pública, sob o aspecto da teoria da regulação, especificamente no âmbito da captura regulatória, a qual se desdobre em proposições que enfatize a insustentabilidade destes processos e priorize o problema.

PALAVRAS-CHAVE: gestão publica, captura regulatória, trabalho escravo, direitos humanos, agronegócio

ABSTRACT: Slavery persists on a global scale 
in the form of indecent work relationships, founded on economic exploitation. The work intends to discuss Brazilian contemporary slavery from the theory of regulatory capture, aiming to demonstrate that because it is included in the global economy, this practice relates in a complex way to corporations and the State. In this sense, it is essential to analyze, under the perspective of public management and regulation, considering including the passage of the Constitucionl Amendment 81/2014, which modified Art. 243 of CF/88. According to the International Labour Organization (ILO, 2009), contemporary slavery is part of the world economy and sustains the production of a range of products. Rare companies, governments or non-governmental organizations engage in or recognize the problematic of contemporary slave labor as a central situation, but only as a peripheral, symptomatic, or even understood as a metaphor ( BALES, 2004; SAKAMOTO, 2008). On the other hand, the debate is also marginal in the social sciences (BALES, 2004), being practically ignored in the field of public management (COOKE, 2003; CRANE, 2013). The scientific contribution to the field of public management is sought, under the aspect of the regulation theory, specifically in the context of regulatory capture, which unfold in propositions that emphasize the unsustainability of these processes and prioritize the problem.

KEYWORDS: public management, regulatory capture, Slave labor, human rights, agribusiness

\section{INTRODUÇÃO}

Para o presente trabalho, o conceito de Trabalho Escravo Contemporâneo é extraído do Art. 149 do Código Penal Brasileiro, bem como referencia o Art.149-A (Crime de Tráfico de Pessoas), o qual representa legamente as formas de reduzir um ser humano a condição análoga à de escravo, quer reduzindo ou suprimindo os meios de locomoção ou o submetendo à condições degradantes de trabalho. Senão vejamos, in verbis:

Art. 149. Reduzir alguém a condição análoga à de escravo, quer submetendo-o a trabalhos forçados ou a jornada exaustiva, quer sujeitando-o a condições degradantes de trabalho, quer restringindo, por qualquer meio, sua locomoção em razão de dívida contraída com o empregador ou preposto: (Redação dada pela Lei $n^{\circ} 10.803$, de 11.12.2003)

Pena - reclusão, de dois a oito anos, e multa, além da pena correspondente à violência. (Redação dada pela Lei no 10.803, de 11.12.2003)

§ 10 Nas mesmas penas incorre quem: (Incluído pela Lei nº 10.803, de 11.12.2003)

I - cerceia o uso de qualquer meio de transporte por parte do trabalhador, com o fim de retê-lo no local de trabalho; (Incluído pela Lei n 10.803, de 11.12.2003)

II - mantém vigilância ostensiva no local de trabalho ou se apodera de documentos ou objetos pessoais do trabalhador, com o fim de retê-lo no local de trabalho. (Incluído pela Lei n ${ }^{\circ}$ 10.803, de 11.12.2003)

\$ 20 A pena é aumentada de metade, se o crime é cometido: (Incluído pela Lei ${ }^{\circ}$ 10.803, de 11.12.2003)

I - contra criança ou adolescente; (Incluído pela Lei no 10.803, de 11.12.2003)

II - por motivo de preconceito de raça, cor, etnia, religião ou origem. (Incluído pela Lei $n^{\circ} 10.803$, de 11.12.2003) 
Tráfico de Pessoas (Incluído pela Lei n 13.344, de 2016)

Art. 149-A. Agenciar, aliciar, recrutar, transportar, transferir, comprar, alojar ou acolher pessoa, mediante grave ameaça, violência, coação, fraude ou abuso, com a finalidade de: (Incluído pela Lei no 13.344, de 2016)

I - remover-Ihe órgãos, tecidos ou partes do corpo;

II - submetê-la a trabalho em condições análogas à de escravo;

III - submetê-la a qualquer tipo de servidão;

IV - adoção ilegal; ou

V - exploração sexual. (Incluído pela Lei no 13.344, de 2016)

Pena - reclusão, de 4 (quatro) a 8 (oito) anos, e multa. (Incluído pela Lei n 13.344, de 2016)

§10 A pena é aumentada de um terço até a metade se: (Incluído pela Lei n 13.344 , de 2016)

I - o crime for cometido por funcionário público no exercício de suas funções ou a pretexto de exercê-las; (Incluído pela Lei n 13.344, de 2016)

II - o crime for cometido contra criança, adolescente ou pessoa idosa ou com deficiência; (Incluído pela Lei no 13.344, de 2016)

III - o agente se prevalecer de relações de parentesco, domésticas, de coabitação, de hospitalidade, de dependência econômica, de autoridade ou de superioridade hierárquica inerente ao exercício de emprego, cargo ou função; ou (Incluído pela Lei $n^{\circ}$ 13.344, de 2016)

IV - a vítima do tráfico de pessoas for retirada do território nacional. (Incluído pela Lei $\mathrm{n}^{\circ}$ 13.344, de 2016)

§ 20 A pena é reduzida de um a dois terços se o agente for primário e não integrar organização criminosa. (Incluído pela Lei n 13.344, de 2016)

Segundo Crane (2013), para entender a escravidão contemporânea pelo ângulo da gestão pública ou da gestão das coorporações é essencial compreender como as empresas empregam práticas ilegítimas para diminuir custos de produção. Neste ponto se estabelece uma rede complexa de relações que envolve alguns braços do Estado, enquanto ente regulador, que pauta as regras, desde as normativas infralegais até mudanças constitucionais, abarcando no mundo jurídico a plêiade de impressões políticas que atingem a administração pública.

Por tal motivo, é importante compreender as teorias regulacionistas sob o aspecto político-econômico, para considerar com a devida importância os atores e condutas que se congregam para que trabalho escravo contemporâneo siga como prática social aviltante. Por outro lado, é fato que submeter a mão de obra necessária a condições indignas para a efetivação do mister do empreendimento, não pode ser aceito como diferencial de competitividade em 2019, no Brasil.

Segundo Ruy Braga (2003, p.430) os regulacionistas buscaram construir uma visão dinâmico-estrutural da economia que a situa dentro de uma perspectiva da Economia Política, da História, da Sociologia e das instituições. A origem e o papel das instituições são apontados como centrais nesse desdobramento que engloba a dialética dos agentes e das estruturas, da lógica e da história.

A problemática do trabalho escravo contemporâneo chama a atenção à dinâmica 
da responsabilidade do Estado, a pressão do empresariado do agronegócio (no caso do trabalho escravo rural), traduzida através do financiamento de campanhas eleitorais e aos danos sociais decorrentes de atividades empresariais que violam a dignidade humana.

Trata-se de uma pesquisa qualitativa e exploratória a fim de desvelar o conteúdo teórico da regulação, sua relação com o trabalho escravo contemporâneo e a compreensão de suas implicações na reprodução da pobreza em determinadas categorias sociais, como no trabalho rural.

Nos termos da Constituição de 1988, o Brasil é um Estado democrático de direito, no sentido de que o ordenamento jurídico fornece as bases, os limites e os objetivos do ordenamento político. O princípio de hermenêutica constitucional, do qual decorrem todos os demais princípios interpretativos, é o princípio da supremacia da Constituição, este enseja obrigatoriedade de interpretação das demais normativas conforme a lei magna, no escopo de que a mesma permaneça soberana e logre efetivar valores aspirados pela sociedade brasileira, como o da dignidade da pessoa humana, valor este indispensável para o debate que se deseja construir e refletir a partir da interface entre normativas constitucionais e a gestão pública, a partir da teoria regulacionista.

A escravidão persiste em escala global na forma de relações indecentes de trabalho, fundadas na exploração econômica. Incontáveis formas de coerção caracterizam relações de trabalho no mercado formado por empresas globais, locais e suas cadeias de fornecedores, alijando trabalhadores de sua dignidade, ferindo seus direitos humanos.

Segundo a Organização Internacional do Trabalho (OIT, 2009), a escravidão contemporânea é parte da economia mundial e sustenta a produção de uma gama de produtos.

Ainda com dados da OIT (2017),

O trabalho forçado é um fenômeno global e dinâmico, que pode assumir diversas formas, incluindo a servidão por dívidas, o tráfico de pessoas e outras formas de escravidão moderna.

Ele está presente em todas as r egiões do mundo e em todos os tipos de economia, até mesmo nas de países desenvolvidos e em cadeias produtivas de grandes e modernas empresas atuantes no mercado internacional.

Acabar com o problema exige não só o comprometimento das autoridades dos govern os, como ta mbém um engajamento multifacetado de trabalhadores, empregadores, organismos internacion ais e sociedade civil.

O trabalho escravo contemporâneo está inserido nas relações de mercado entre organizações globais e seus fornecedores, e abrange práticas de gestão que fustigam a dignidade humana e os direitos humanos, com o cerceamento da liberdade, a violência física e psicológica, as condições degradantes de trabalho e as jornadas exaustivas de trabalho.

Este trabalho se articula para fazer avançar nossa compreensão da problemática e pensar em suas implicações à gestão pública pelo recorte da regulação e sua carga de colaboração à manutenção e reprodução da prática escravagista moderna 
nas organizações. A metodologia utilizada foi a revisão bibliográfica das teorias regulacionistas e a análise documental. Neste sentido, pretende-se obtemperar a seguinte pergunta de pesquisa: em que medida a reprodução da lógica do trabalho Escravo Contemporâneo está apoiada na regulação estatal?

\section{O TRABALHO ESCRAVO CONTEMPORÂNEO NO CONTEXTO DAS} IMPRESSÕES POLÍTICAS DOS GRUPOS DE INTERESSE TRADUZIDAS NA REGULAÇÃO ESTATAL: COMPLEXIDADE DAS RELAÇÕES ENTRE ESTADO E EMPREENDEDORES

O Brasil, inserido no sistema de mercado globalizado, com a problemática do trabalho escravo contemporâneo, suscita atenção à dinâmica da responsabilidade do Estado, que cede ou corrobora com a pressão do empresariado do agronegócio, seja através do financiamento de campanhas eleitorais ou da assunção dos cargos do poder legislativo por integrantes do setor ruralista, isto é, os danos sociais decorrentes desta conduta empresarial com o apoio do Estado, em seus diferentes eixos, acabam por violar a dignidade humana.

Pelo fato da sociedade brasileira estar inserta no contexto globalizante de produção, há forte tendência à inobservância de direitos humanos, no escopo da saturação do aumento de lucros e competitividade organizacional. Assim, o direcionamento das políticas de combate à escravidão contemporânea sofrem resistência na representação dos interesses das classes dominantes.

O cotejo da categoria construída pela legislação penal no art. 149 (BRASIL, 2018) a qual define a prática de reduzir pessoas à condição análoga a de escravo com a redação da Emenda Constitucional n 81/2014 que alterou o Art. 243 da Constituição Federal de 1998 (BRASIL, 2015), auxilia na compreensão de que se está diante de uma realidade permeada de contradições, que podem agregar uma plêiade de visões sobre a prática, inclusive opiniões políticas que objetivam transformar as situações indignas - de trabalho exaustivo, degradante, por dívidas - em violação exclusiva da legislação trabalhista, as quais concluem-se com punições mais brandas.

Tal fato será evidenciado na análise dos textos de leis e demais documentos que atribuem materialidade às políticas de combate à escravidão contemporânea, inclusive com conteúdos contraditórios, que podem se anular entre si.

Como exemplo, tem-se o voto do Presidente da Comissão de Constituição, Justiça e Cidadania, publicada no Diário do Senado Federal em 25 de março de 2014 
(p.85-86), através do Parecer $n^{\circ} 180 / 2014$, que fundamenta a rejeição da Emenda $n^{\circ} 1$, proveniente do Plenário do Senado Federal, a qual reformulava o texto original da PEC para a expropriação de terras onde fossem encontrados trabalhadores escravos, com vistas a inserir a aposição da expressão "na forma da lei".

Todavia, o mesmo ator político reformula seu voto sem qualquer explicação pública, o que leva à aprovação da Emenda Constitucional, com as modificações propostas pela bancada ruralista, na clara tentativa de esvaziar a conceituação de Trabalho Escravo Contemporâneo a partir do que a norma penal acima exposta já regulamenta.

Outro ponto importante, a fim de evidenciar e exemplificar os meandres observados da teoria da captura regulatória e sua interseção com a gestão pública está na relação de cotejo entre a "lista suja dos escravagistas contemporâneos", onde estão os empregadores que praticaram o Trabalho Escravo Contemporâneo, produzido pelo hoje extinto Ministério do Trabalho e Emprego, que quando cruzados com dados quantitativos das eleições gerais de 2014 , verifica-se que $10 \%$ dos deputados federais eleitos foram financiados nas campanhas eleitorais por empreendedores que figuraram ou figuram na citada lista suja, a qual é elemento de divulgação social oficial que possui critérios e parâmetros para sua confecção, adotada como um indicador.

Reforçando que o presente estudo segue uma metodologia eminentemente qualitativa, para explorar as situações legislativas e regulatórias, que modificadas ou em processo de aperfeiçoamento, beneficiem os grupos de interesse focados na manutenção da prática do trabalho escravo contemporâneo.

Neste ponto, gestão pública, sob a perspectiva da teoria da captura regulatória, enfatiza-se a insustentabilidade destes processos e prioriza a problemática a partir da compreensão do eixo de desenvolvimento que mantém e reproduz a prática do trabalho escravo contemporâneo, mesmo que supostamente em termos jurídicos, existam instrumentos capazes de erradicar a escravização contemporânea, os agentes públicos responsáveis pela regulação, em todos os níveis, podem ser capturados.

\section{I REFLEXÃO SOBRE OS FUNDAMENTOS DA TEORIA DA CAPTURA REGULATÓRIA E A RELAÇÃO COM TRABALHO ESCRAVO CONTEMPORÂNEO} E

Sobre a Teoria da Captura regulatória, observa-se que esta advém a análise de um estado regulador e garantista, quando a fundamentamos na perspectiva de um Estado Democrático de Direito. Assim, há uma clara diferença do minimalstaat da época liberal e do maximal staat do século XX.

A partir do conceito de garantia, para indicar um Estado garantista, seja em direitos fundamentais ou direitos humanos, este ideário surge como afirmação de que o Estado permanece, sob certas premissas específica, intervindo no controle socioeconomico. 
O Estado mantém uma posição de garantidor da realização de dois objetivos ou interesses fundamentais: Correto funcionamento dos setores e serviços privatizados e Realização dos direitos dos cidadãos, direitos a se beneficiar, em condições acessíveis, de serviços de interesse geral.

Para um conceito inicial de regulação, esta seria a forma de atuação do novo modelo de estado para corrigir o mercado e garantir a realização do interesse público, mas assume-se neste ponto o compromisso de pesquisar as várias conceituações de regulação.

Entre estes, para Pedro Gonçalves (2013), em linhas gerais, se trata da intervenção estadual externa na esfera da economia, do mercado e, em geral, das atividades privadas desenvolvidas em contexto concorrencial. Conceito que abarca a regulação setorial e a regulação transversal, aplicável à generalidade dos agentes econômicos.

Relacionando o conceito de regulação e a teoria da captura, a regulação é uma forma de atuação do estado garantidor com vistas ao interesse público. Logo, o interesse público é a dimensão legitimadora, uma vez que a regulação se assume como uma atividade administrativa.

Entre os principais autores que estudam a captura regulatória, Stigler (1971) descreve que esta teoria deriva de falhas existentes no próprio processo regulatório, esclarecendo que a regulação não é realizada $a b$ initi em prol do interesse público e mesmo sendo exercida em prol do interesse público em sua fase inicial, acaba por ser capturada pelas empresas do setor ou por qualquer outro grupo, passando a existir para prosseguir interesses privados em vez do interesse público, como deveria ser. Os principais Modelos teóricos sobre a captura regulatória se encontram em G. Stigler da Escola de Chicago (1971).

Para este autor, em regra, a regulação é adquirida pela indústria regulada e é concebida e executada primariamente em seu benefício, sendo estabelecida, não para a prossecução do interesse público, mas para beneficiar os agentes privados e seus interesses.

Os principais fundamento da tese de Stigler estariam sintetizadas no ponto de que os políticos terão como objetivo a maximização de seu poder político e da sua riqueza, sendo que irão tomar as decisões que lhe confiram um de dois benefícios, mais votos ou mais dinheiro.

Agindo estes indivíduos com vista à maximização do seu próprio bem-estar, está criada a base para que as empresas os "capturem" com vista à obtenção de benefícios próprios através de regulações favoráveis.

Neste sentido, haveriam categorias de benefícios que os políticos podem conferir às empresas ou indústrias, quais sejam: subsídios diretos em dinheiro; controle da entrada de novos concorrentes no mercado; medidas que limitem a produção de bens sucedâneos; fixação de Preços.

Os benefícios devem ser entendidos como vantagens as quais se concretizam 
na obtenção de uma renda superior ao que o grupo empresarial ou grupo de interesse obteria caso operasse num mercado numa situação de concorrência perfeita.

Assim, a captura se concretiza em troca de votos ou dinheiro, o que implica custos, para Stigler são custos de informação e de organização: por um lado, os membros do grupo tem de saber em quem votar e, por outro, têm de se organizar num esforço de lobbyng, fornecendo contribuições políticas e tentando exercer sua influência.

As principais críticas à Escola de Chicago estão no fato de que a pesquisa e seu desenvolvimento evidencia apenas nas empresas como único grupo que pode pretender capturar o regulador. No entanto, pode haver outras entidades com interesse nessa captura. George Stigler assume que a regulação é feita por políticos diretamente eleitos.

Acerca da Escola de Virginia, Teorias da Escolha Pública e do Rent Seeking, temos como principais autores, James Buchanan e Gordon Tullock (1992), os quais pretendem analisar as falhas do Estado e do governo.

Para os autores, todos os agentes estaduais agem na prossecução dos seus próprios interesses privados, não sendo capazes de corrigir as falhas de mercado que legitimam a intervenção reguladora do Estado. Ainda que conseguissem fazê-lo, os custos de tal correção terminariam por ser superiores aos custos para o bem-estar social decorrentes das próprias falhas de mercado corrigidas. Neste caso, a teoria foca nos custos para a sociedade ou custos sociais.

A respeito da teoria do grupo de interesses, a qual integra estudos sobre o lobbying, e a teoria do rent seeking, que é sobre os custos do lobbying. Assim, esta vertente discorre sobre se as falhas das decisões regulatórias são decorrentes da captura dos agentes reguladores, combinada a uma complexa rede de influências na qual os próprios legisladores são integrantes de determinada categoria social, como no caso da bancada ruralista brasileira no congresso nacional, que vem diuturnamente defendendo aumento da produtividade a partir do descumprimento de leis trabalhistas e da redução dos trabalhadores à condição análoga a de escravos.

No que concerne à Escola de Toulouse, esta tenta explicar as assimetrias de informação e o ciclo de vida das entidades reguladoras e tem-se como principais autores Laffont e Tirole (1993), sua principal linha investigativa centra-se nas assimetrias de informação existentes entre as entidades reguladoras e seus supervisores.

No que toca aos efeitos da captura regulatória, esta quando ocorre, transforma a regulação pública numa espécie de auto regulação privada, uma vez que as entidades reguladoras capturadas iriam agir de modo a beneficiar agentes privados, dando uma prevalência aos seus interesses sobre o interesse público, que são obrigadas a prosseguir.

Neste sentido, haveriam alguma implicações práticas como a transferência desigual de rendas entre empresas ou grupos econômicos, por exemplo o objetivo da captura, quando realizado por um grupo de empresas, é a obtenção de uma renda (WREM-LEWIS, LIAM, 1961, p.6), definida como um rendimento superior ao que o 
grupo obteria caso operasse num mercado numa situação de concorrência perfeita.

A finalidade da captura, como acima mencionado, seria o de desviar rendas para o captor, subtraindo-as aos outros agentes em jogo, isto porque para a renda de um dos grupos aumentar, a dos outros tem de diminuir: para aumentar a renda do produtor tem de diminuir a do consumidor, sendo a afirmação inversa igualmente verdadeira.

Pode-se também verificar impactos na eficiência econômica, através das distorções nos preços: desvio de rendas de um grupo para o outro, que provoca distorções, os custos econômicos e sociais e principalmente, como no caso do trabalho escravo contemporâneo, as alterações nas políticas publicas que atendem aos interesses de um determinado grupo econômico, traduzidas na regulação, como no decreto presidencial que proibiu a divulgação das empresas e empresários escravocratas no fim de 2017 ou na alteração do próprio texto final da emenda constitucional aprovada, objetivando a desconstrução epistemológica formatada sobre um conceito legal.

Na conexão entre a captura regulatória e o trabalho escravo contemporâneo no Brasil, pode-se perceber através das pesquisas documentais que embasaram os votos sobre a Emenda Constitucional n 81/2015, a qual aprovou a modificação do Art. 243 da $\mathrm{CF} / 88$, nuances da teoria apresentada no discurso político utilizado, reconfigurando as perspectivas que desaguaram na aprovação de uma emenda constitucional após 19 (dezenove) anos, que ao fim acabou trazendo no bojo do seu texto a necessidade de regulação, desfigurando o que com duras penas se havia obtido com a conceituação de trabalho escravo do Art.149 do CPB.

\subsection{Histórico sobre o conceito de trabalho escravo contemporâneo no contexto} político brasileiro e as bases jurídico-constitucionais que são influenciadas pela captura regulatória referenciada

A categoria trabalho escravo se tornou conhecida para a sociedade civil, por intermédio de movimentos e defensores de direitos humanos, os quais passaram a atuar e conscientizar as próprias vítimas sobre a superexploração da mão de obra, em caráter de indignidade e violação dos atributos virtuosos dos seres humanos, os quais capturavam a consciência e a racionalidade. Em seguida, a imprensa passou a dar ampla publicidade à questão do trabalho escravo e o tema passou a integrar a agenda nacional das políticas públicas governamentais.

Em virtude de pressões a nível internacional, o governo brasileiro reconheceu, no relatório que apresentou em 1994 ao Comitê de Direitos Humanos da ONU, relativo ao cumprimento do Pacto Internacional dos Direitos Civis e Políticos, "a existência de trabalho "não-livre" no país, bem como encaminhou minuta de emenda constitucional para incluir como áreas passíveis de desapropriação aquelas terras onde tivesse comprovado essa prática" (BALLESTRIN, 2006).

O fato do trabalho escravo ser tratado hodiernamente como uma "categoria da 
ação política", é decorrente de grandes embates nas searas nacionais e internacionais para seu reconhecimento, o que em grande parte definiu, em termos decisórios, a ação política do estado brasileiro.

Tais avanços lograram êxito através da construção e estruturação do conceito de Trabalho Escravo Contemporâneo, nos termos do art. 149 do CPB, com a participação de entidades nacionais e internacionais que internalizaram a virada epistemológica necessária à reconfiguração de parte do estado brasileiro, conforme se pode apreender da ação das agências governamentais de fiscalização das condições de trabalho, entre eles o extinto Ministério do Trabalho e Emprego, Ministério Público do Trabalho, Polícia Federal, e por fim interferiram nas considerações dos agentes do direito, por meio de decisões judiciais e definições legais.

A prática do Trabalho Escravo Contemporâneo, se expressa em proteção e impunidade para grandes empeeendedores, constrangimento e indignidade para os desprovidos de alimentação, emprego e moradia. Esta prática não existe somente na zona rural, apesar de a maioria de trabalhadores originarem-se destas áreas, devido justamente à precariedade das oportunidades de trabalho e a facilidade de serem mantidos nas propriedades rurais devido o difícil acesso a meios de transporte e estradas, por dívidas ou mesmo por ignorância quanto aos seus direitos de trabalhador.

Pode-se inclusive exemplificar, no âmbito das grandes cidades, trabalhadores urbanos reduzidos à condição análoga a de escravo, mantidos coagidos pelos proprietários de oficinas de costuras em São Paulo, trabalhadores latinos pobres e sem perspectivas em seus países de origem, geralmente bolivianos e paraguaios (MENDES, 2003).

Nesses casos, os empregadores apropriam-se coativamente de sua documentação e os ameaçam de expulsão do país por meio de denúncias às autoridades competentes. Obstados de se locomoverem para outras localidades, diante da sua situação irregular, os trabalhadores submetem-se às mais vis condições de trabalho e de moradia, geralmente coletivas (MENDES, 2003).

Sento-Sé chama atenção para a triste sina que envolve o homem do campo, nordestinos em sua maioria, que coloca toda a sua esperança na lavoura, apostando seus anseios na atividade agropecuária, mas que se vê no desamparo, em face das intempéries da natureza e dificuldades trazidas pela seca. Tal agricultor fica sem perspectivas para sua subsistência e de sua família (SENTO-SÉ, 2000).

É nesse momento que, envolto no desespero decorrente da precária situação, passa a ser compelido a aceitar qualquer oferta que possa proporcionar-lhe, pelo menos, a chance de mudar o seu destino. Daí é um passo para ser convencido a ir trabalhar em uma fazenda ou propriedade rural, bem distante da sua cidade natal, iludido de que receberá um salário razoável.

Neste ponto, se observa o que Sergio Lessa (1997, p151) introduz sobre a necessidade na teoria ontológica de Lukács sobre a relação entre o ser social e o trabalho: 
vimos que a necessidade, posta pelo processo de objetivação, que o conteúdo de uma posição teleológica incorpore, em algum grau, as determinações do ser-precisamente-assim existente, conduz a uma pulsão para a captura, pela consciência, das determinações objetivas do real. Vimos como este impulso é o fundamento ontológico da gênese e desenvolvimento de representações do real que buscam integrar as determinações do ser-precisamente-assim existente numa totalidade teórica coerente. [...] o que nos interessa, agora, é salientar que as representações mais gerais que os homens fazem do mundo como um todo, assim como de suas próprias individualidades, exercem um papel não desprezível na determinação do que e de como será objetivado e, por esta via, sobre a reprodução social global. O que, mais uma vez, evidencia como a consciência se torna um momento essencial ativo do ser social que está surgindo.

O recrutamento dos trabalhadores rurais é feito pelos prepostos dos proprietários, geralmente conhecidos como "gatos". Estes são os responsáveis por aliciar com propostas irreais as futuras vítimas:

estes homens chegam com um caminhão a uma área afetada pela depressão econômica e vão de porta em porta ou anunciam pela cidade toda que então recrutando trabalhadores. Às vezes usam um alto-falante, ou o sistema de som da própria cidade. [...] Em muitos casos, tentam conquistar a confiança dos recrutados potenciais trazendo um peão, que pode já ter trabalhado para eles, para reunir uma equipe de trabalhadores. O elemento de confiança é importante, e sua criação é favorecida pela capacidade que tem o gato de dar uma imagem sedutora do trabalho, das condições e do pagamento que esperam os trabalhadores (SUTTON, 1992:35).

O "gato" normalmente adianta determinada quantia em dinheiro, a fim de que atenda às necessidades mais urgentes de seus familiares por determinado período, antes do início de suas atividades, ou antes da viagem ao local onde prestará o serviço. Dessa forma, o trabalhador já inicia o labor contraindo débitos perante o futuro empregador.

Como afiança José de Souza Martins, citado ainda por Sento-Sé :

especialmente aos jovens e solteiros, são oferecidas condições de trabalho melhores que as locais: assistência médica, contrato, bom salário, transporte. Promessas que não serão cumpridas. Um adiantamento é deixado para a subsistência da família. É o início do débito que reduzirá à escravidão. Quando chegam ao local de trabalho, após muitos dias de viagem, já estão devendo muito. E o débito crescerá sempre: tudo que consumirem custará no barracão da fazenda três vezes mais do que custa normalmente. E o salário prometido se reduzirá a dois terços ou metade. Ou menos. O débito é o principal instrumento da escravização: justifica a violenta repressão contra esses trabalhadores. (SENTO-SÉ, 2000:43).

O trabalho escravo é descrito historicamente, desde os tempos mais remotos da antiguidade clássica e infelizmente ainda persiste na sociedade contemporânea, ainda que hodiernamente não se mantenha o escravagismo como modo de produção regulado.

O liame que difere a condição do trabalhador escravo contemporâneo com as condições de trabalho escravo de dois séculos atrás não é muito expressivo, sendo a condição jurídica da concepção de liberdade e da necessidade de sobrevivência, o 
ponto nodal para a compreensão da problemática.

A escravidão de hoje é uma forma extrema de exploração da vida do trabalhador, que se demonstra incorporado ao padrão mudializado de desenvolvimento global, atrelado, inclusive a braços do Estado e do grande capital.

As novas formas de escravidão no mundo podem se manifestar desde a escravidão por dívida, até os mais atuais tipos de escravidão, como o originário da imigração. O tráfico de pessoas e o comércio sexual também podem ser considerados formas contemporâneas de escravidão.

\section{I A TEORIA DA CAPTURA REGULATÓRIA DIANTE DA PROBLEMÁTICA} DO TRABALHO ESCRAVO CONTEMPORÂNEO, NOS ARRANJOS INTERRELACIONAIS ENTRE SETOR PÚBLICO E PRIVADO REVELADOS NO BOJO DA APROVAÇÃO DA EMENDA CONSTITUCIONAL N. 81/2014

O Congresso Nacional aprovou a emenda constitucional n81/2014, a qual prevê o confisco de propriedades em que a prática do trabalho escravo contemporâneo for constatado, com a consequente destinação das propriedades à reforma agrária ou a programas de habitação urbanos.

Por se tratar de Emenda a Constituição, ela não precisou de sanção presidencial, haja vista que passa por um processo legislativo mais intrincado, qual seja, deve ser votado em dois turnos em cada uma das casas, que compõem o Congresso Nacional, passando a valer imediatamente após sua promulgação.

Não obstante a ocorrência da alteração constitucional, a qual tramitou por 19 anos no Congresso Nacional, uma subemenda de redação também foi aprovada, acrescentando ao texto a seguinte expressão: "na forma da lei" à proposta. O que traz a baila a questão do esvaziamento da conceituação do trabalho escravo contemporâneo e por conseguinte da eficácia da legislação, que passa a ter uma condicionante para sua efetividade.

Cabível ressaltar, que a maior parte dos senadores que aprovaram a PEC, durante anos, trabalharam nos bastidores para inviabilizar a votação e a aprovação, o que remete a questão, porque ocorreu mudança ideológica sobre a aprovação? Tal questionamento serve como ponto de partida para a análise documental que envolveu a aprovação da Emenda Constitucional.

Tem-se o voto do Presidente da Comissão de Constituição, Justiça e Cidadania, publicada no Diário do Senado Federal em 25 de março de 2014 (p.85-86), através do Parecer $n^{\circ} 180 / 2014$, que fundamenta a rejeição da Emenda $n^{\circ} 1$, proveniente do Plenário do Senado Federal, a qual reformulava o texto original da PEC com vistas a inserir a aposição da expressão "na forma da lei", todavia o mesmo ator político, reformula seu voto sem qualquer explicação pública, o que leva à aprovação da Emenda Constitucional, com as modificações propostas pela bancada ruralista, esvaziando a 
conceituação de Trabalho Escravo Contemporâneo.

Com a leitura do parecer $\mathrm{n}^{\circ} 38$ de 2014, o qual apresenta emendas ao Projeto de lei do Senado Federal $n^{\circ} 432 / 2013$, observamos a necessidade dos parlamentares, desviarem do que se entende legalmente por trabalho escravo contemporâneo, a partir de outro texto legislativo, qual seja, o art. 149 do Código Penal, acima mencionado.

Ao analisarmos o Projeto de Lei, em seu $a r t 1^{\circ}, \S 1^{\circ}$, este traz apenas trabalho escravo como fruto da restrição da liberdade de locomoção, excluindo o trabalho em condições degradantes, inclusive no $\S 2^{\circ}$ do Projeto de lei, ele é claro em avençar que o descumprimento da legislação trabalhista, não se enquadra como trabalho escravo.

Tal afirmação não pode ser acatada, a partir de um ponto de vista crítico e legal o que, haja vista que dependendo do grau das ações que descumpram questões trabalhistas, estas podem sim ser enquadradas como trabalho escravo contemporâneo, conforme se depreende das proposições do Art. 149 do CPB.

Outra situação de retrocesso, é o $\S 7^{\circ}$ do mesmo PL, o qual aduz que é vedada a inscrição, em cadastro público, de pessoas físicas e jurídicas que sejam parte em processo que envolva a exploração de trabalho escravo anteriormente ao transito em julgado de sentença condenatória, haja vista a intenção de extinguir as listas consolidadas de proprietários infratores de ógãos como o MTE e CPT, os quais durante muitos anos foram as principais fornecedoras de informações, em razão das regulares fiscalizações.

A mudança da conceituação defendida pelo parecer em apreço, é analisada de forma crítica pela análise do discurso, enquanto metodologia, considerando que a atividade legislativa e seu planejamento versam sobre sistemas e práticas, sociedade e cenários, campos nos quais o discurso atua dinamicamente como aparato ideológico. Os produtos desta breve investigação anunciam que o discurso é um instrumento considerável de estruturação ideológica nas práticas sociais.

O que o partido no governo faz, então, é buscar votos, e não o atendimento à programática evolutiva constitucional; com isso, Downs submete a atividade governamental ao mesmo uso que a microeconomia faz da empresa oligopolista: "a política governamental visa a maioria, e investe até que a taxa marginal de retorno não compense mais o investimento" (DOWNS, 1999, p. 71-72 ). Mas, ao contrário do que parece, este modelo é mais complicado quando se considera o papel da incerteza e o custo da informação.

No mundo de desorientação, a informação torna-se uma ferramenta de conquista de votos pela persuasão através do discurso empreendido: esse papel é exercido pelas lideranças políticas, pela descentralização do Estado e pelas ideologias partidárias (DOWNS, p.1999 108-109 e 119-120).

O modelo do discurso analisado, ratifica que os comportamentos dos governantes e o dos governados são interdependentes, e a racionalidade é garantida pela premissa de que ambos seguem o axioma do auto-interesse.

Sopesando que a percepção que se obtém a partir dos dados coletados está à 
serviço da compreensão dos fenômenos sociais, assume que o comportamento humano pode, em várias medidas, ser estudado, ou modelado, através do pressuposto da racionalidade, conforme apregoa a teoria da captura regulatória, acima demonstrada.

Diante da apreciação, compreende-se alguns pontos estratégicos dos fatos em tela, quais sejam, após 19 anos o Congresso Nacional aprova uma Emenda Constitucional com forte apelo social, pois a sociedade brasileira, em termos gerais, se demonstra contrária à prática da escravidão contemporânea por ser visceralmente atingida, considerando o contexto histórico brasileiro.

Parlamentares não podem se expor contrários aos interesses do eleitorado, pois dependem dos votos para ascensão e manutenção do poder. Por outro lado, jamais tomarão medidas de cunho político sem viabilizar o auto-interesse, razão de ser de suas candidaturas e representação de eleitores, setor ruralista e demais empreendedores descompromissados com os fundamentos da temática em apreço.

Neste sentido, presenciamos discursos e votações em favor da democracia e dignidade humana, mas sem eficácia perante aos fatos, quando analisamos as propostas de lei, que visam regulamentar um ponto já e regulamentado no art. 149 do Código Penal, também ato legislativo, fornecendo indícios de que o Estado regulador está capturado.

\section{CONSIDERAÇÕES FINAIS}

A permanência da concepção de trabalho escravo contemporâneo nos termos do Art. 149 é necessária enquanto fator de resistência ao esvaziamento do itinerário evolutivo que se pretendeu em prol do resgate e consolidação da dignidade humana.

A gestão pública, em seu braço regulador, influenciada por certos atores econômicos, distancia-se do cumprimento dos objetivos da República Federativa do Brasil e de outros dispositivos constitucionais, como os Artigos 173 e 186 da mesma carta constitucional.

O ensaio em tela, vem relacionar através da teoria da captura regulatória do Estado brasileiro, quando da moderação em prol do trabalho escravo contemporâneo, que sucumbir à influência de determinadas categorias socioeconômicas que trabalham diuturnamente em prol da competitividade no modelo capitalista de produção, significa fustigar o valor social do trabalho e a dignidade humana, em seu conceito mais profundo.

Percebeu-se neste estudo, a dificuldade de efetivação das normas legais e constitucionais, quando desprovidas dos valores sociais fundantes, bem como da vulnerabilidade do modelo democrático diante dos interesses de atores políticos, responsáveis pelos regramentos e regulamentos.

Demonstrando, ainda que com fragilidades, por se tratar de um estudo exploratório, teórico e documental, como as regras jurídicas, que podem determinar comportamentos sociais e efetivar direitos humanos, podem vir a desintegrar soluções e 
conceitos jurídico-políticos construídos paulatinamente com as modificações exaradas a partir de estratégias pensadas no jogo político, inviabilizando a consecução do que estabelecido como garantia constitucional.

\section{REFERÊNCIAS}

BALES, K, 2004. Disposable People: New Slavery in the Global Economy. University of California Press

BRAGA, Ruy, 2003. A nostalgia do fordismo: modernização e crise na teoria da sociedade salarial. São Paulo, Xamã.

BRASIL, 2015.Constituição da República Federativa do Brasil.20. ed.São Paulo: Revista dos Tribunais. RT Legislação.

BRITO FILHO, J. C. M. de. 2004. Trabalho com redução do Homen à Condição Análoga à de Escravo e Dignidade da pessoa Humana. Revista Gênesis, Curitiba, nº 137:673-682

BUCHANAN, James. M., TULLOCK, Gordon, 1962. The Calculus of Consent: Logical Foundations of Constitutional Democracy, Ann Arbor: University of Michigan Press.

COMISSÃO PASTORAL DA TERRA - CPT, 2017. Entre idas e vindas: novas dinâmicas de migração para o trabalho escravo / [coordenação] Centro de Defesa da Vida e dos Direitos Humanos Carmen Bascarán - CDVDH/CB ; -- 1. ed. -- São Paulo : Urutu-Branco.

DELMANTO, Celso, 2001. Código Penal Comentado. São Paulo: Renovar.

DEPUTADOS. Camara. Acompanhamento da PEC 438/2001. Disponível em: <http://www.camara.gov. $\mathrm{br} /$ proposicoesWeb/fichadetramitacao?idProposicao=36162> acesso em 01.set.2015.

DOWNS, Anthony, 1999. Uma teoria econômica da democracia. São Paulo, Editora da Universidade de São Paulo.

FAIRCLOUGH, Norman. 1989. Language and Power. Harlow: Longman Group UK Limited.

FAIRCLOUGH, Norman. 1995. Critical Discourse Analysis. Harlow: Longman Group UK Limited.

FIGUEIRA, Ricardo Rezende, 2004. Pisando Fora da Própria Sombra: A escravidão por dívida no Brasil contemporâneo. Rio de Janeiro: Civilização Brasileira.

GONÇALVES, Pedro. Reflexões Sobre o Estado Regulador e o Estado Contratante. Coimbra Editora, 2013.

HIGGINS, Silvio Salej, 2005. Fundamentos Teóricos do Capital Social. Chapecó, Editora Argos. LAFFONT, J. J.; TIROLE, J. A theory of incentives in procurement and regulation. Cambridge: The MIT Press, 1993.

LESSA, Sérgio. Lukács e a Ontologia: Uma Introdução. outubro, São Paulo, 2001, p. 83-100.

LOCATELLI, P. Empresas flagradas com trabalho escravo financiaram 10\% dos deputados federais. Disponível em:http://reporterbrasil.org.br/2018/01/empresas-flagradas-com-trabalho-escravofinanciaram-10-dos-deputados-federais/. Acesso em 31.01.2018.

MAUES, H.N. A redução de trabalhadores â condição análoga à de escravo como fator de 
descumprimento da função social da propriedade rural. Anais do XVI CONPEDI, Belo Horizonte, 2007: 2749-2768

MENDES, A. N. Imigrantes em condição análogas a de escravo. Revista do Ministério Público do Trabalho, Brasília, 2003: 67-70.

MIGUEL, Juan Francisco Delgado de, 1992. Derecho agrário ambiental: propiedad y ecologia. Pamplona: Aranzadi.

MORAES, Alexandre de, 2000. Direitos Humanos Fundamentais. 3.ed. São Paulo: Atlas.

MORAES, Alexandre de, 1996. Direito Constitucional.9. ed. São Paulo: Atlas, 2001. SCHIMITT, Carl. Teoria de la Constitución. Madrid: Alianza Editorial.

NACIONAL. Congresso. Parecer $n^{\circ} 38$, de 2014 às Emendas apresentadas ao Projeto de Lei $n^{\circ} 432$, de 2013. Disponível em:< http://www.senadofederal.gov.br >. Acesso em: 15 de mai. 2015.

SAKAMOTO, Leonardo. Os entraves políticos no combate ao trabalho escravo, $2008 \mathrm{http}: / /$ reporterbrasil.org.br/2008/09/os-entraves-politicos-no-combate-ao-trabalho-escravo/ acesso 07.06.2018.

SENTO-Sé, Jairo Lins de Albuquerque, 2000. Trabalho Escravo no Brasil, São Paulo: Ltr.

SÜSSEKIND, Arnaldo, 1994. Convenções da OIT, São Paulo: Ltr.

SUTTON, Alison,1992. Trabalho Escravo: Um elo na cadeia da modernização do Brasil de hoje. São Paulo:CPT.

TULLOCK, Gordon, «The Welfare Costs of Tariffs, Monopolies, and Theft», Western Economic Journal 5, 1967: 224-32 


\section{CAPÍTULO 11}

\section{ORGANIZACIONES, PODER Y CULTURAS POSMODERNAS}

Edgar Varela Barrios Ph.D en Administración. Profesor Titular. Rector Universidad del Valle Ernesto José Piedrahita Mg. En Administración. Investigador. Universidad del Valle.

Correo electrónico.piedra.ernesto@gmail.com Teléfono móvil +573012803666

RESUMEN: Un análisis del campo organizacional desde distintos focos filosóficos entre los cuales aparecen, el pragmatismo, el vitalismo, el posestructuralismo, buscando desentrañar las lógicas con las cuales han operado las organizaciones en el pasado y operan en el presente. Elementos como el poder, su aplicación managerialista y el mundo del trabajo también son abordados a la luz de una conceptualización que combina el aporte de pensadores y filósofos de distintas épocas con los hallazgos y desarrollos concebidos y difundidos por grandes teóricos de las llamadas ciencias de la organización.
PALABRAS-CLAVE: Poder, management, organizaciones, posmodernidad

Las tecnologías y dispositivos y procesos del poder managerial y organizacional constituyen un amplio foco de investigación. teniendo como referente pivotal a M. Foucault (1977), quien construyó una arqueología y genealogía del poder desde la perspectiva de las relaciones humanas, a través del análisis de las prácticas.

Foucault, sin hacer una discusión estrictamente analítica y filosófica del poder, no cayó tampoco en la lógica positivista científica de que el poder es solo un objeto mensurable. Que se puede medir y validar estadísticamente para comprenderlo positivamente. Sino que construyó desde sus aportes postmodernos un camino antropológico-arqueológico, no estrictamente filosófico, que correspondía también, aunque no exclusivamente, a la documentación, e investigación social, historiográfica y hermenéutica. Además, a través de la etnografía, la que no siempre será la etnografía en el sentido estrictamente antropológico, sino usando el método de análisis documental etnográfico, incluyendo las propias construcciones reglamentarias discursivas, los testimonios de época, etc., lo que podríamos 
llamar una etnografía articulada a la antropología cultural.

En trabajos posteriores a Foucault como los que hicieron Deleuze y Guatari (1972) y otros autores, estos filósofos se diferenciaron fuertemente en sus métodos, frente a la vieja filosofía analítica, discursiva y autocentrada. Pensadores como Rorty (1985) recuperaron la impronta de los filósofos del final del medioevo y comienzos de la edad moderna. Es decir, actuando como pensadores humanistas que investigaban los sistemas de prácticas y las técnicas científicas de su época. Por ejemplo, Descartes era físico. Pierce, a su vez, era un teórico de la lingüística y fundador de la semiótica, en tanto que W. James era psicólogo y trabajó temas de observación y conducta social y organizacional. Del mismo modo, ocurrió con J. Dewey. Filósofos contemporáneos de la postmodernidad han reivindicado los valores centrales de la filosofía en el sentido griego de la palabra. Han roto la positivación ritual de la filosofía como una suerte de supraciencia analítica. Nietzsche o Heidegger, igualmente reflexionaron sobre las prácticas humanas y sus formas de representación. Y si no tuviesen esa capacidad de comprender las ciencias humanas, las ciencias sociales

y los discursos científicos no hubieran construido filosofía fecunda. Hablando en términos de comprensión del poder organizacional y managerial, la positivación del discurso sobre el poder, si bien es cierto lo ayuda a comprender, es insuficiente ${ }^{1}$. Atando el pragmatismo con el foucaultianismo y la discusión que los teóricos postmodernos han cambiado, lo que hila esta reflexión es el reconocimiento de los sistemas de prácticas de Arendt, la acción humana o la recuperación y la puesta en escena como instrumento analítico de una forma mucho más fuerte y diversa de lo que es poiesis, no solamente explicando desde la metáfora biológica como la de los sistemas autorregulados ,como lo expresó la cibernética de mitad del siglo pasado, sino desde la poiesis como una pulsión humana en unas sociedades en donde cada vez más la gente tiene la posibilidad de ser productora, creativa e innovadora.

El presente trabajo recoge diversos "puntos de entrada" a los análisis del poder managerial, para lo cual se tienen en cuenta teorías y epistemes del pragmatismo, el vitalismo y el racionalismo, y de algunos de los más representativos analistas de los

1 El esfuerzo de la escuela del Public Choice de simplificar e instrumentalizar el poder, basados en el liberalismo político esencial, puede observarse en el libro de Anthony Down sobre burocracia en el que hay una clara muestra de este camino y de su insuficiencia, si se considera que los burócratas son sujetos egoístas, entonces se colocan reglas conductistas de premio y castigo, y a partir de allí se determina cómo mejorar el comportamiento organizacional de las burocracias con incentivos o castigos. Esto es puro conductismo transmutado desde un discurso sofisticado, que incluso se puede sistematizar, como ejemplo de ello, en muchas investigaciones sobre corrupción que están en esa lógica. Suponer el egoísmo humano como el dato desde el cual se parte, es algo más moral y valorativo que científico, aun cuando después, sobre eso, se haga toda la ciencia que se desee. 
temas organizacionales vinculados con los análisis del poder.

\section{I EL PRAGMATISMO Y EL VITALISMO SE RECONFIGURAN EN LA POSTMODERNIDAD}

Nos interesa abordar la relación del pragmatismo con el foucaultianismo en la discusión sobre los sistemas de prácticas. Citando a Arendt, la acción humana, la recuperación y la puesta en escena como instrumento analítico de la poiesis, no solamente explicándola desde la metáfora biológica como sistemas autorregulados, cfr en la cibernética de mitad del siglo pasado, sino desde la poiesis como pulsión humana en unas sociedades en donde cada vez más la gente tiene la posibilidad de ser productora, creativa e innovadora. El ser humano como homo faberu homo sapiens ha configurado un mundo de imágenes, religiones; un mundo cosmológico, del cual la última producción postmoderna es la virtualidad. En esta transición e hibridación de epistemes existe la posibilidad de que las máquinas se vuelvan inteligentes y puedan ser apropiadoras, lectoras del mundo cultural producido por el hombre. También esta transición, durante el modernismo, caracterizó el proyecto civilizatorio e hizo posible una dinámica de interacción humana devenida en la diferenciación entre naturaleza y cultura.

En general, se tiende hoy hacia una convergencia del vitalismo y el pragmatismo, corrientes que en el siglo XIX se veían muy distantes. La tesis que etiquetaba a James (1955), Peirce (1883) y otros autores del siglo XIX como Dewey (1884) como idealistas, ha sido inadecuada. Los pragmatistas no son idealistas; los pragmatistas neokantianos consideran las prácticas humanas como esquema central para la verdad y el discurso. Pero dichas prácticas no son vistas desde una perspectiva de utilidad, a diferencia de los utilitaristas franceses del principio del siglo XIX. Son vistas desde el punto de vista de la concreción humana en praxis societales de distinto tipo. Deleuze, Foucault y otros autores postmodernos de la segunda mitad del siglo pasado resignificaron las prácticas, propulsando una corriente anticartesiana, opuesta a la fundamentación de conceptos y categorías universales construidas sin relación alguna con la experiencia humana. El vitalismo de estirpe nietzscheana no toma la idea de igualdad, de pluralismo, salvo en términos de diversidad, no como pluralismo político (propio al liberalismo). Se podría decir que detrás de ello hay una concepción de naturaleza humana, una ontología que aparece oculta por la epistemología. Hacemos una discusión centrada en el ámbito cognitivo, en el proceso de racionalización, y ese tipo de discusión nos oculta la ontología. Es el conocer que encubre al ser. Se pretende que el ser se entienda por la vía del conocer.

Resulta conveniente en este punto del análisis recordar como Deleuze interpretó la realidad desde el punto de vista del sentido y el significado compartido (Isla, 2015). Es, además, un asunto que Rorty y los neo-pragmáticos han reivindicado. Se puede 
conectar la transformación del viejo pragmatismo, bajo la forma de neo- pragmatismo, con el vitalismo. Es clave obtener una dimensión cultural de las prácticas para reconocer las trasmutaciones sociales del hombre natural ${ }^{2}$. Para Hardt y Negri (2000), el vitalismo de hoy se enfoca hacia la libertad humana como una forma renovada de comprender positivamente el biopoder. Lo han postulado con firmeza, rompiendo con una tradición que establece diferencias frente a los primeros teóricos vitalistas del final del siglo XIX, incluyendo a Nietzsche y a Pareto. Diferenciaban con claridad a las élites y a la masa. El atributo de la pulsión vital se lo otorgaban a las élites. En contraste, por las características de las transformaciones sociales, el revival del vitalismo estaba arraigado en la "multitud".

Para Virno, Negri, Hardt, la multitud no incluye a los capitalistas, empresarios y clases medias. En el modelo de ellos, la multitud correspondería a la población dominada; aquella que, aunque tiene una función mucho más activa y dinámica, sigue definiéndose por las estructuras de dominio. Es necesario recusar los criterios de exclusión. Las nociones de Commonwealth, Comunidad, son cercanas a lo que Espósito (2002) denominó comunidad y que emergía como una suerte de mediación resolutiva entre las estructuras políticas y la sociedad. El error metodológico de excluir a los dominadores de la multitud radica en que no se puede explicar todo tipo de flujos y dinámicas, sino consideramos que todos estamos en la multitud. Los pensadores de este concepto, influidos por un marxismo militante, reconocían la matriz hegeliana de distinción entre Estado y sociedad civil; la cual sustenta la concepción marxista del socialismo radical del último siglo y medio. También en ella se sustentan las teorías de las clases sociales y la separación entre los ámbitos político y económico. Virno construye, desde el neo marxismo, la gramática de la multitud -al igual que Agamben y Espósito- con sus reinterpretaciones de la bio política, radicalizando la idea de que este emergente vitalismo corresponde a comunidades políticas y no solamente a las élites tradicionales; idea que todavía no estaba expresamente planteada en Deleuze y Guattari (1980). Virno asumió que la creación humana no necesariamente supone la producción económica. Alternativamente, Deleuze tuvo una profunda influencia marxista en su juventud, que se reflejó en pasajes del Antiedipo, como su referencia a los sistemas de producción macro, con tópicos derivados de la llamada economía política.

En este punto se deben reconocer los avances y aportes de numerosos

\footnotetext{
2 Arendt (1958) nos recuerda que Locke distingue labor and work en un esquema basado en Aristóteles. Los seres humanos como seres vivientes tienen la doble condición de ser, simultáneamente, homo laborans y homo faber. Esta es solo una vertiente, en tanto que por el homo laborans se entendería la enunciación de la actividad como acción respecto de la potencia. El trabajo sería un cierto tipo de actividad productiva que supone la capacidad de reproducir las condiciones de vida del ser social (John Locke). Se vive como homo laborans pero solo se pueden reproducir las condiciones de la vida cuando se trabaja. Y trabajar significa producir económicamente o producir socialmente, y no se trataría de una función - citando a Luhmann- solo autorreferencial (labor), sino heterorreferencial (work). La función de heterorreferencia es la del homo faber. Una función estrictamente autorreferencial sería la función de ley.
} 
pensadores posmodernos que fueron más allá de la noción de Marx, de la producción vista solo y primordialmente como valorización económica; de la producción humana reconocida solo en la dimensión limitada del trabajo productivo frente al trabajo improductivo. En otra perspectiva, desde una mirada postmoderna, se fundamentó la capacidad de la creación humana -de individuos, grupos, organizaciones y totalidades sociales macro-, en términos más amplios que la noción de producción. En la actualidad se ha sobrepasado la distinción entre el saber decidir y el saber hacer, característica del primer capitalismo tayloriano. Esta dicotomía hoy ya no tiene sentido en relación con el papel del manager en las organizaciones. El concepto de multitud de Negri y Hardt constituye, por lo tanto, una pista importante en la formulación según la cual, desde finales del siglo XX, el vitalismo - usando un término anacrónico- se ha plebeyizado. Virno habla del hombre-pueblo, concepto que en cierta manera reconfigura e invierte los argumentos de Ortega y Gasset y de la primera literatura vitalista del final del siglo XIX y comienzos del XX. Las sociedades contemporáneas han re-fundado el vitalismo y lo han plebeyizado. Deleuze y Guattari leyeron tendencias que se han consolidado en las décadas siguientes. Ellos pensaron en la postmodernidad desde la teoría crítica y desde una filosofía que tomó como referentes problemas concretos de la sociedad. Pero no solo trabajaron sobre la noción de sociedad, también abordaron la cosmología, que llamaron geo-filosofía. Allí aparecen elementos no centrados sobre el sujeto, como la territorialidad y los rizomas. No se trata de una antropología filosófica cuyo centro de reflexión es el hombre. Su discusión sobre las mesetas o estratos, contiene referencias al mundo, pero sin separar el mundo natural del mundo social.

La movilidad nos brinda una posibilidad rizomática -para citar la metáfora- raizal. Hasta hace cincuenta años quien migraba "quemaba las naves": se iba y no volvía. Hoy la movilidad es muy grande y la brindan los medios y la cultura. No solo es una movilidad económica, se presenta en muchos campos. Por otro lado, con la noción de máquinas deseantes3 se formuló una integralidad cósmica de lo natural, lo tecnológico y lo social. Las máquinas se basan, ontológicamente, en códigos que se encuentran tramados, almacenados en ellas. Este código no es solo inseparable de su registro y de su transmisión en las diferentes regiones del cuerpo, sino también del registro de cada una de las regiones en sus relaciones con las otras (Deleuze y Guattari, 1980; 1985). De allí derivan los encadenamientos entre las partes, las regiones, los cuerpos y los propios seres humanos.

La perspectiva ontológica, de corte maquínico humano deseante, les permitió a Deleuze y Guattari interpretar los flujos, las dinámicas, los movimientos, las transiciones de las sociedades y de los cuerpos en estrecha sintonía con los ámbitos

\footnotetext{
3 El discurso postmoderno tomó como base unareferenciación expresa de las llamadas "máquinas deseantes" y del hombre-máquina. Este tema tiene una importante discusión que bien vale la pena referirla, tomando como eje las correlaciones entre el poder humano y las maquinas inteligentes. Deleuze y Guattari lo abordaron extensamente en sus dos opus magnum, El "Antiedipo" y
} 
natural y tecnológico. Esto implicaba la capacidad de las máquinas humanas de hacer cortes, rupturas, producir discontinuidades, enlazadas con lógicas relacionales, a la vez homogéneas y diferenciadoras. Lo deseante fue leído por estos filósofos franceses cómo una relación funcional inherente entre el deseo y la producción; como "realidad psíquica". Recordemos que el concepto de máquina deseante de Deleuze y Guattari es vitalismo puro y duro. Comentaristas significativos de su obra reivindican la cercanía expresa y confesa de estos autores con el pragmatismo americano, y en especial con el pensamiento de James y Peirce. De otro lado, una nueva generación de intelectuales, en el campo de la epistemología, han reivindicado el pragmatismo.

Una pista importante de Deleuze y Guattari emerge cuando hablan de la división del trabajo; pero hoy no se podría adjudicar, en su dimensión económica, solo las dialécticas de des- territorialización y re-territorialización. La conectividad cultural, lúdica, cognitiva que tenemos con el internet, con las redes virtuales, nos cambia de territorio sin desplazarnos. En nuestro imaginario, el arraigo al territorio actual no es igual al que se tuvo en el pasado. Al estar instalados en nuestro tiempo nos cuesta pensar en las realidades de otros tiempos. El territorio nuestro no es el territorio de la geopolítica clásica. Bajo el modelo anterior tayloriano, las organizaciones estaban configuradas sobre una espacialidad, un territorio, una planta física. Incluso, en el esquema foucaultiano, la fábrica se parece a una cárcel, a un lugar de encierro clásico. En contraste, las organizaciones actuales aparecen con una fuerte desterritorialización, con un mayor grado de virtualidad-temporalidad y una menor sujeción a las fronteras de la espacialidad.

Según Deleuze y Guattari, el agenciamiento expresa, mediante políticas públicas, los cursos de acción, su trayectoria, impacto y lógica, pero no como una representación, sino como prácticas o dinámicas de acción, pulsiones. Una pulsión no existe en potencia, una pulsión se ejerce: solo en el ejercicio es pulsión. Allí se manifiesta una ruptura con la lógica aristotélica de potencia y acto. El agenciamiento representa una unidad mínima o básica, pues, explícita las relaciones entre los diversos colectivos humanos; pone en juego las tramas de interdependencia entre las poblaciones con sus multiplicidades, afectos, intensidades y territorios. Sin embargo, para Deleuze y Guattari siempre el agenciamiento sería, ante todo, territorial. Se trataba de pensar una geografía de las multiplicidades como condición para el movimiento y para que se pueda generar el devenir de la historia. Deleuze y Guattari (1985) dejaron tópicos claves, pistas, que solo hasta hace pocos años empezaron a ser discutidas por teóricos del Management y de la teoría organizacional. Redescubrir sus concepciones sobre espacialidad, territorialidad, rizoma, máquinas y máquinas deseantes, permite reactualizar en el Management la literatura de frontera. Se convierte en un registro innovador desde la filosofía política contemporánea sobre la sociedad, las organizaciones, en una perspectiva posmoderna.

La obra de estos autores también fue influyente sobre la dinámica de la desterritorialización. Inicialmente, propusieron el modelo rizomático como un modelo 
anti jerárquico, esbozando una estructura con múltiples raíces y permitiendo la participación y la multiplicidad de sus partes. Este modelo no está limitado por el tiempo y el espacio sino por nodos que nacen, mueren, se conectan entre sí y van evolucionando. ¿Cuándo formulan la crítica del rizoma arbóreo tratan de describir cómo se construye o cómo se conforma la sociedad que se está desarrollando? El ser humano está atravesado, segmentado, por múltiples instituciones. La contraposición del modelo arbóreo se centra en el pensamiento binario tradicional. La estructura arbórea se manifiesta en la memoria larga, mientras que la rizomática se manifiesta en la corta, que son ideas concisas, discontinuas, de ruptura, múltiples y sometidas a la ley de la continuidad. La micropolítica de segmentación plantea que estamos segmentados por todas partes; todo lo vivido espacial y socialmente está segmentarizado circular, lineal y binariamente.

Lo binario se puede referir a las clases sociales, hombre-mujer, adulto-niño; lo circular, a la relación de los asuntos de un individuo con los asuntos de la familia, de la ciudad, el país, el continente, el mundo. Por su parte, lo lineal, quiere decir que una vez vamos terminando procesos, empezamos con otros. Estamos segmentados en estas tres dimensiones. El Estado también ejerce una propia segmentaridad y la impone; de modo que la vida moderna no ha llegado a suprimir la segmentaridad, si no que la ha afianzado. Antes de la existencia del Estado ya existía la segmentación, por ejemplo, en las comunidades primitivas. La segmentaridad es connatural a las estructuras del racionamiento social y se relaciona con la espacialidad y el territorio. Existe, entonces, una segmentaridad primitiva y otra moderna, rígida, molar, con instancias bien definidas, arraigadas a las instituciones. Dichas instituciones van a depender de máquinas no diversas, no solamente dualistas, sino dicotómicas que funcionan diacrónicamente y van a complementar la segmentaridad flexible, primigenia (molecular). Todo ello produce flujos, nuevas composiciones que no coinciden necesariamente con el segmento, sino que construyen devenires. Lo molecular a diferencia de lo molar hace referencia a las intensidades, donde ya no hay relaciones de velocidad o lentitud.

La especie humana está sumergida en un inmenso movimiento de desterritorialización; sus territorios originales se rompen ininterrumpidamente con la división social del trabajo, con la acción de dioses universales y con la relación de sistemas maquínicos. La desterritorialización se considera un movimiento por el cual se abandona un territorio a través de la operación de las líneas de fuga y, gracias a ello, se presenta una reterritorialización, es decir, un movimiento hacia la nueva construcción del territorio. Deleuze y Guattari nos dan pistas acerca de la crítica del racionalismo dominante en el Management y en la teoría organizacional, con respecto a la teoría del actor presente en Merton, en Parsons, en la corriente sociológica estructural funcionalista. Resulta absolutamente articulador el pensamiento de Simon y la escuela del Management estratégico. Tal teoría propone un actor que es coherente, que actúa de manera integral desde la lógica de su racionalidad, y en el cual existen relaciones causa- efecto, por ejemplo, en la discusión entre decisión y acción. Es 
claro el orden: primero se decide, luego se actúa. Hay una coherencia entre el decidir y actuar relacionada con fines y medios. La concepción de Guattari y Deleuze rompe radicalmente con el racionalismo de tipo cartesiano.

La metáfora rizomática es muy importante; significa una crítica al positivismo tecno-científico. En vez de quedarse en las evidencias, en los datos -en la información que nos brinda el árbol-, se debe escudriñar en su base; en la raíz que le da sustento. En la actualidad los territorios son radicalmente diferentes (incluso la propia noción de soberanía resulta anacrónica; pues, la gubernamentalidad como tecnología del poder para el control de la población ya no tiene el efecto que describía Foucault hace tres décadas). Filósofos contemporáneos como Agamben, Sloterdijk, el propio Deleuze, Guattari, Foucault, no son clásicos en el sentido estricto de la palabra; no realizan una filosofía que pretende ser omnicomprensiva, como era la primera filosofía hasta el siglo XVIII, ni hacen una filosofía en campos que podrían llamarse residuales.

\section{I VITALISMO, SISTEMAS DE VERDAD Y MANAGEMENT}

Un ejemplo de cómo se exacerba el vitalismo en la modernidad con los CEO, es cómo hoy en día el gran flujo del discurso que la gente busca escuchar, o que se promueven para administrar, no es el discurso del gerente. Hoy en día no se invita al CEO de una gran empresa a una conferencia, representante de la competitividad, del vitalismo, de los valores de espíritu y a la vez biológicos, para que expongan a los administradores. Eso sustenta de una manera muy gráfica la presencia del vitalismo en el management. Es fecundo que Foucault, en vez de hacer una discusión estrictamente analítica y filosófica del poder, no cae tampoco en la lógica positivista científica de que el poder es un objeto mensurable, que se puede medir y validar estadísticamente para comprender positivamente, sino que construye una suerte de otro camino antropológico- arqueológico, no estrictamente filosófico, pero que, desde la documentación, hace investigación social como historiador, yendo a archivos y documentos haciendo hermenéutica.

Las teorías foucaultianas del poder no son esquemas arbitrarios ad hoc, pues la propuesta de sociedad disciplinaria es una suerte de síntesis de estudios detallados de Foucault sobre los sistemas de práctica, mirándolos en términos de sus transformaciones históricas, sin tener una metateoría detrás que permita construir y alumbrar con facilidad desde un modelo científico positivo. Este es un tema que es muy importante comprender a través de etnografía, que no siempre será la etnografía en el sentido estrictamente antropológico, sino de lo documental etnográfico de distinto tipo, incluyendo las propias construcciones reglamentarias discursivas, los testimonios de época, etc., lo que podríamos llamar más como una etnografía articulada a antropología cultural. La pregunta sería arqueológico- etnográfica, en el sentido de discursos e ideologías: ¿los saberes, discursos y dispositivos ideológicos y representacionales de hoy de dónde vienen? Cuál es el decurso de esto que llamamos 
Management; arqueológicamente visto como historia de las ideas, y también como análisis retrospectivo de las prácticas, representaciones, discursos.

En la actualidad, las tecnologías del poder, instrumentalizadas desde las ciencias de la administración, contribuyen de manera significativa a expandir el poder de los altos mandos directivos y las cúpulas del poder organizado. La postmodernidad y el hiper industrialismo capitalistas han permitido una mayor capacidad de control y regulación del poder corporativo. Igualmente, han propiciado diversas y complejas formas de asociación de éste con los poderes públicos en marcos cada vez más globales y trasnacionales. Sin embargo, el actual y refinado discurso managerial ignora, tanto el cambio de época como la concentración y centralización, incluyendo los medios hiper tecnológicos virtuales y digitales, propios de nuestra época.

Resulta interesante subrayar la manera como Foucault apreciaba la verdad en función de los sistemas de prácticas. El papel de las prácticas humanas es esencial para configurar -como él lo hizo- las genealogías y entender el rol del Management en las sociedades contemporáneas. Foucault formuló las tecnologías de poder y al poder lo pensó como tecnología. Este autor recusaba la idea de construir meta discursos sobre el poder del tipo "teorías del Estado" o teorías políticas clásicas contemporáneas, tales como el contractualismo o el institucionalismo. Consideraba clave, incluso desde los siglos XIV y XV (orígenes de la sociedad moderna), ver al poder como tecnologías, como dispositivos de dominación. Estas ideas son, al mismo tiempo, discursos sobre la verdad y la legitimidad; es decir, discursos articulados a procesos cognitivos y a los sistemas de prácticas humanas. Sobre este terreno surge la lógica disciplinaria, discursiva, tecno científica.

Hay una suerte de cierre en el ciclo de un paradigma unificado; el cual ya no es de carácter racional, racional instrumental, ni racional limitado. No es el paradigma del Management dominante de carácter estratégico, sino la antípoda de ese mismo paradigma, en la medida en que se reconocen las prácticas, la discursividad sobre esquemas vitales de biopolítica y biopoder, y el ejercicio de dichas dimensiones. Pareto, Gaetano Mosca, Michells, y el resto de estos teóricos de principios del siglo $\mathrm{XX}$ y de finales del XIX, podrían ser elitistas, porque según el discurso elitista una minoría dirige y las masas obedecen. Este era el panorama, el retrato de la enorme diferenciación social que existía entre dirigentes y dirigidos, managers y trabajadores, entre el liderazgo público y las comunidades, en una época donde las diferenciaciones sociales eran muy grandes y la noción de democracia de participación y de comunidad política postmoderna, aún no eran pensables.

Por su parte, el vitalismo contemporáneo es un vitalismo repolitizado. Virno señala que el escenario más político es la fábrica. Por los lenguajes del empoderamiento social, la participación no solamente debe ser vista con base en esquemas top down, sino como esquemas de carácter transversal. Las sociedades en red, las sociedades comunicadas, la interacción, la idea del prosumer (el productor que es a la vez consumidor) son situaciones inéditas. No son utopías, sino prácticas humanas 
de las sociedades globales postmodernas. Emerge la reinstalación de un vitalismo que integra al pragmatismo; se trata, curiosamente, de una corriente importante en la filosofía política y social contemporánea, pero que no existe en el Management. Vistos críticamente, los elementos morales, filosóficos y críticos son insuficientes o inadecuados. La filosofía política siempre tiene un sustrato de la filosofía moral, la cual consiste en la discusión filosófica (no científica) acerca de qué es lo bueno, lo malo, lo deseable, lo indeseable; a qué se adhiere y a qué se rechaza. Se trata de centrarnos en los sistemas de valores que tenemos los individuos y las sociedades. Aquellos no son reductibles a ningún tipo de lógica racional-científica. Desde el siglo XIX se fundaron las ciencias positivas, con la sociología de August Comte, con Durkheim al final del siglo XIX y con el desarrollo de la economía como ciencia-técnica. Todas estas ciencias sociales se separaron de la filosofía y la recusaron con el argumento según el cual esta disciplina es una suerte de discurso especulativo y general que no ofrece explicaciones de tipo científico.

\section{I LA RACIONALIDAD MANAGERIAL, PUESTA EN CUESTION}

La idea del conocimiento absolutamente predecible, proyectable y anticipatorio fue dejada de lado en las ciencias sociales, aunque ha influido muchísimo en el Management ${ }^{4}$. El relativismo radicalizado se convertiría en agnosticismo, como versión light del nihilismo que recusa radicalmente los sistemas de verdad y solo asume una indiferencia moral de fondo respecto de qué es y qué no es verdadero. Esta discusión acerca de lo verdadero, nos conduce al tercer campo, dominante hoy en las ciencias sociales y en el Management, que se denomina de dos maneras: constructivismo y convencionalismo.

¿Cómo se construyen los sistemas de verdad y de referenciación lógicos desde este campo? Se los configura generalmente a partir de convenciones de carácter deductivo o ad hoc, los cuales permiten determinar las características de un discurso, sus componentes y la relación con la forma como la interacción de estos discursos construye sistemas representacionales (el lenguaje binario, el matemático decimal y la sintaxis lingüística, son ejemplo de ellos). El convencionalismo no opera solo en las ciencias, opera en el mundo de la vida y en las representaciones discursivas, las imágenes y figuras que permiten comprender el color de las señales de tránsito son un convencionalismo social. El constructivismo es la forma sofisticada del convencionalismo, opera como meta teoría y como meta discursividad científica, es el éxito del constructivismo.

El papel subalterno que hoy tiene el relativismo y la anulación del nihilismo corresponden al predominio de la tecnociencia. La vertiente expresada en el mundo

\footnotetext{
4 Por ejemplo, en la racionalidad limitada de Simon y en buena parte de los teóricos influidos por Pareto (vía la difusión de Lawrence Henderson).
} 
organizacional y social se concreta ahora en el llamado posthumanismo; un discurso de exacerbación de la tecnología y predominio de la tecnologización, como modos de vida del ser humano postmoderno. No somos conscientes de lo que somos, de hasta qué punto estamos inmersos en la cyborización. El relativismo, como paradigma, se afirmó en el siglo pasado a partir de la revolución epistemológica que introdujo la física de partículas, la teoría de Heinsenberg sobre incertidumbre, la teoría subatómica, la teoría de la relatividad de Einstein y la teoría del quantum. Emergió, al principio del siglo pasado, en las ciencias exactas y naturales, por ejemplo, en la geometría distinta a la de Euclides, en las geometrías que conciben universos y espacios curvos, la geometría de Euclides es el equivalente en el mundo geométrico a la concepción espacio temporal de Newton. El elemento sofisticado que impregna a las ciencias naturales y exactas llega a las ciencias sociales y a los paradigmas científicos. La ciencia de la primera mitad del siglo XX creía que una parte de ella daba verdades universales indiscutibles e inamovibles.

El siglo XX dio paso al relativismo epistemológico. Hoy en las ciencias el paradigma relativista es absolutamente dominante. La ciencia del siglo XIX está enterrada. No es que no haya racionalidad instrumental, ciencia o tecno ciencia, sino que estos dos campos no tienen el monopolio de la "verdad" desde las teorías científicas y desde los discursos sobre la legitimación de la verdad. Lo que hay en los discursos de la ciencia son relatos, meta relatos, narrativas. No se encuentra una diferencia de fondo entre una novela y un texto científico. Varios teóricos de la física mostraron, por ejemplo, que el comportamiento de las partículas subatómicas es aleatorio, no rigidez en el marco de lo subatómico fundamentado desde la microfísica contemporánea (teoría fractal y otros tipos de discursos relacionados con la microfísica). Los críticos de este discurso van a plantearse que lo que existe hoy son relatos, narrativas o discursos que no son explicativos de la "realidad" o del mundo objetivo.

El post modernismo rompe el predominio de la ciencia técnica como paradigma unificado. Allí, se encuentra, en el pragmatismo del siglo XIX y XX, una fuente fecunda de contradicciones de cartesianismo, y a la vez, seminalmente, algo que sembrado en el management ha permitido su emergencia y hegemonía, a pesar de ser un corpus que disciplinariamente no tiene los mismos niveles de calidad, complejidad, erudición y sofisticación de otras ciencias. Si se compara la sociología con las ciencias de la gestión, desde el punto de vista de su complejidad discursiva no hay mucho qué hacer, es una comparación inadecuada, es otro tipo de discurso articulado más a los sistemas de prácticas y menos a los procesos meramente articulados a la comprensión. Si se pretende la comprensión en el management, un empresario o político exitoso no requiere el ejercicio de auto comprensión, o esta es situacional, no teorética; la compresión teorética es de los académicos y no de los sistemas de prácticas. En cada una de estas posturas se reinterpretan los postulados de Weber, y allí hay una nueva episteme que viene a ser ahora la burocracia que viene a darse tras el ideal organizacional de autoridad como los procesos de institucionalización, es decir, como 
unos nuevos cambios de visión que reinterpretan y que vienen a estar en la burocracia desde otras formas.

Allí hay un problema epistémico complejo cuando los paradigmas de las ciencias positivas emergieron en los siglos XIX y XX. En cierta manera, nosotros somos víctimas de ello, porque el encasillamiento disciplinar, en las ciencias sociales y humanas, ha hecho crisis. O incluso en muchos otros campos a la hora de la verdad, cuando quiere resolver problemas los hacen equipos transdisciplinarios y no manteniendo las estructuras epistémicas y los sistemas de verdad de cada disciplina. Como James Thompson lo había definido: los campos de dominio del management están articulados a la propia fuerza y dinámica de los conglomerados organizacionales, que no dependen de los derechos de propiedad, sino que pueden colocarse como esquemas complementarios y octogonales, circuitos que se encierran y articulan dinámicamente con el otro. El capitalismo de hoy está atravesado por la biotecnología, por la manipulación orgánica y las transformaciones en el campo de lo "bio" que implican nuevas productividades y reproducciones del capitalismo cosmopolita. El determinismo tecnológico considera que, en las interacciones entre seres humanos, la mayor o menor libertad de acción, dependerá de la sofisticación de los recursos tecnológicos. En este sentido, se puede hablar, en el campo del Management y en la teoría de las organizaciones, de la complejidad organizacional, retomando a Durkheim (1987) quien diferenció las organizaciones simples con relaciones bastante libres y abiertas (primitivas) de las organizaciones complejas en las cuales el juego de la tecnología 5 estaría en función de las estructuras del poder. Se debe decir que el racionalismo modernista no brinda respuesta frente a la transformación epistemológica que acontece, aún no la hemos logrado capturar.

Existe, en este sentido, una gran distancia entre el modelo organicista del Management clásico y el modelo de poder organizacional y político contemporáneo. El primero era, en síntesis, un modelo cartesiano hombre-máquina, un modelo bastante mecánico que sustentaba la concepción del equilibrio y las dinámicas simples y mecánicas de lo organizacional. El segundo es mucho más proteico, digital. Buena parte de las promesas de la racionalidad limitada han sido convertidas en inteligencia artificial, en posthumanismo, en el viejo paradigma planteado por Pareto: la diferencia entre lo humano y lo no-humano ${ }^{6}$. En cierta manera los textos de Simon y de la escuela del Management estratégico fueron desencadenantes de la inteligencia artificial para resolver problemas relacionados con asuntos epistemológicos y cognitivos, para anticipar, normalizar y protocolar, así se pudo concebir que se puede resolver la incertidumbre a partir de la configuración de protocolos.

\footnotetext{
5 Por tecnología no se entienden solamente los instrumentos o artefactos, puesto que las estructuras administrativas, las formas organizaciones y de gestión, son también tecnologías de organización. Además, las estructuras del poder, como las describedescritas por Foucault (2004a), como consecuencia de la bio-política, y del bio-poder (saber, verdad, poder) están en función de la tecnología. No de manera gratuita Foucault inauguró la discusión sobre las tecnologías de poder y las tecnologías de poder para la gobernanza.
} 
Muchas de las tecnologías de dominación no son el resultado de decisiones expresas de orden voluntario o intencional, son el fruto de interacciones sistémicas y de las propias lógicas de funcionamiento de sistemas sociales organizados, expertos y complejos. Allí juegan un papel mayor la informatización y la cibernética, como campos de diseño de las acciones humanas. Las mega organizaciones cada vez más se apoyan en sistemas de robots sofisticados y extendidos; estos artefactos reformulan los lugares y las nuevas relaciones trans-espaciales de las llamadas políticas organizacionales de dirección estratégica. Hoy se habla del internet entre las personas, que permite una interacción en la que digitalizamos comunicaciones y relaciones sociales, la interacción social, se trata de un mundo que pareciera eliminarlas de dinámicas como por ejemplo la laboral (Cifuentes, 2016). También se habla del internet de las cosas (Evans, 2011), esquemas de comunicación e información digitalizados que permiten que las cosas transmitan información entre ellas7. El internet de las cosas lleva un estadio fuerte de la robótica y genera impactos sobre la gobernanza, es decir, sobre la esfera que tradicionalmente hemos tenido los seres humanos para decidir. Rhodes (1996) mencionaba que la humanidad se dirigía hacia esquemas en los cuales los sistemas automatizados, la ciborización, la informática y la biotecnología, transformarían la gobernanza de las organizaciones complejas. En este sentido, las tareas que los seres humanos cumplimos en las organizaciones, sobre todo las de carácter mecánico, no serán decididas y realizadas por seres humanos sino por sistemas maquínicos.

\section{REFERENCIAS}

Agamben, G. (1995). Homo Sacer.

Aktouf, O. (1989). Le management entre tradition et renouvellement de

Aktouf, O. (2002). Administración y Pedagogía. Colombia: Editorial Universidad Eafit Andrews, K. (1968) Introduction to the thirtieth anniversary edition of The Functions of the Executive. Cambridge, MA: Harvard University Press.

Arendt, H. (1958). The Human condition. Chicago IL: University of Chicago press.

Argyris, C. (1957). Personality and organization; the conflict between system and the individual. New York: Harper \& Row Barnard, C. (1956). Organization and Management: Selected Papers. Cambridge: Harvard University Press.

de datos que máquinas le dan a otras máquinas, son pues procesos que prácticamente, sin ninguna intervención humana.

6 Por lo no-humano se entendía no solo el componente mecánico, también la propia tecnología y la misma naturaleza.

7 Movilidad de una ciudad, sistemas de cámaras de seguridad, neveras que reportan el número de los productos y la necesidad de ellos, que producen información que va no solamente a ojos humanos sino a centros de mando con sistemas computarizados que integran, parametrizan y también actúan en función de datos que máquinas le dan a otras máquinas, son pues procesos que prácticamente, sin ninguna intervención humana. 
Barnard, C. (1938). The functions of the executive. Cambridge: Harvard

Benjamin, W. (1999). Para una crítica de la violencia y otros ensayos: iluminaciones IV/llumnaciones IV (No. 1Benjamin). Taurus.

Benjamin, W. (2001). Tesis de filosofía de la historia. Etcétera.

Buchanan, J. M., \& Tullock, G. (1962). The calculus of consent (Vol. 3). Ann Arbor: University of Michigan Press.

Calvo, D. (2017). Conversación personal con el autor. Enero de 2017.

Castro, S. (2010). Historia de la gubernamentalidad. Razón de Estado, liberalismo y neoliberalismo en Michel Foucault. Bogotá: Siglo del Hombre, Pontificia Universidad Javeriana- Instituto pensar, Universidad Santo Tomás de Aquino.

Chanlat, A. (2005). El rombo filosófico y los cuatro modos de ser. Conferencia dictada en la Universidad Eafit. Medellín.

Clegg, B \& Birch, P. (2002). Crash course in creativity. London: Kogan Page.

Coser, L. (1954). The functions of Social Conflict. New York: Free Press.

Deleuze, G. y Guatari, F. (1980). "Capitalisme et Schizophe Nie Mille Plateaux". Paris: Les Editions de Ninult.

Deleuze, G. (1999). Posdata sobre las sociedades de control. Descartes, R. (1994). Meditaciones metafísicas. Panamericana Editorial.

Dewey, J. (1884). The new psychology. Andover Review, 2, 278-289.

Heidegger, M. (2009) El ser y el tiempo. (Trad. Gaos, J.) 2da. Ed. México: Fondo de Cultura Económica

Hume, D. (1953). Ensayos políticos. Buenos Aires: Printower Media.

Isla, P. (2015). Investigación en Dirección de Organizaciones: la idea de Acción y Cognición en perspectiva. IV Coloquio

internacional e sociología da Ciencia da Administraçao.

Brasil: Florianópolis.

Etzioni, A., (1961), A comparative analysis of complex organizations. New York: The Free Press. Foucault, M. (1966). Las palabras y las cosas: una arqueología de las ciencias humanas. Buenos Aires: Siglo veintiuno editores.

Foucault, M. (1976). Vigilar y castigar. Buenos Aires: Siglo XXI Editores.

Foucault, M. (1980). Microfísica del poder. España: Ediciones de La Piqueta.

Foucault, M. (1988). El sujeto y el poder. Revista Mexicana de Sociología, 50(3), 3 - 20.

Foucault, M. (2004b). Seguridad, territorio y población. Buenos Aires: Fondo de Cultura Económica.

Foucault, M. (2008). Nacimiento de la clínica: Una arqueología de la mirada médica. Buenos Aires: 
Siglo veintiuno editores.

Foucault, M. (2014). Histoire de la folie à l'âge classique. Editions Gallimard

Freud, S. (1914). Tótem y tabú. Buenos Aires, Argentina: Amorrortu.

Freud, S. (2013). La interpretación de los sueños. Madrid: Ediciones Akal

Goffman, E. (1955). On Face-Work: An Analysis of Ritual Elements in Social Interaction. Buenos Aires: Editorial Paidós.

Goffman, E. (1959). La presentación del yo en la vida cotidiana. Madrid, Amorrortu, 2004.

Hardt, M., \& Negri, A. (2004). Multitud: guerra y democracia en la era del Imperio. Editorial Debate. Hegel, G. W. F. (1821) [1970]. Filosofía de la Historia. Editora: Zeus.

Henderson (1967) Pareto's General Sociology: APshysiolgist's Interpretation. New York: Russell and Russell. Kant, I. (1781/1973). Crítica de la razón pura. Buenos Aires: Losada Especial.

Khan, R. (1981). La violencia y el desarrollo económico y social. La Violence et ses Causes. París. Unesco.

Lazzarato, M. (2002). From Biopower to Biopolitics. Pli: The Luhmann, N. (1997). Organización y decisión. Autopoiésis, acción y entendimiento comunicativo. España. Universidad Iberoamericana y Anthropos.

Luhmann, N. (1997). "La teoría de la sociedad". México: Triana editores - Universidad Iberoamericana. Maturana, H., \& Varela, F. (1980). Autopoiesis and cognition: The realization of the living. Springer Science \& Business Media.

Negri, A., \& Hardt, M. (2000). Empire. Exils Éditeurs, Paris, 1.

Negri, A. (2008). Reflections on Empire. Cambridge: Polity Press.

Nietzsche, F. (2018) La voluntad de poder. (Trad. Aníbal Froufe). Madrid: Editorial Edaf.

Pareto, V. (1917). Traite de sociologie genérale. Vol 1. Paris: Librairie Payot.

Pareto, V. (1972). Manual of political economy. Oxford: Oxford University Press.

Parsons, T. (1951). The Social System. New Yorkand London: The Free Press and Collier Macmillan. Rifkin, J. (1999). El siglo de la biotecnología: el comercio genético y el nacimiento de un mundo feliz. Barcelona: Crítica-Marcombo.

Simon, H. (1964). On the concept of organizational goal. En: Administrative Science Quarterly, Vol. 9, No. 1, pp. 1 - 22. Nueva York: Johnson at Cornell University.

Simon, H. (1973). Las ciencias de lo artificial. Barcelona: El Ateneo Editorial.

Simon, H. (1979). Rational Decision Making in 48. Business Organizations. American Economic Review, 69, 493-513.

Simon, H. (1991). Models of My Life. Cambridge: MIT Press.

Simon, H. (1997). Administrative behavior: A study of decision making processes in administrative organizations. New York: The Free Press. 
Sloterdijk, P. (2000) Normas para el Parque Humano, una respuesta a la Carta sobre el humanismo, Madrid, Ediciones Siruela, 2008

Sloterdijk, P. (2003). Crítica de la razón cínica (Vol. 23). Siruela.

Sloterdijk, P. (2006). El desprecio de las masas. Revista Santander, (1).

Thompson, D. (1967). Organizations in Action. New York: McGraw Hill.

Varela, E. (2014). Biopoder, Biopolítica y Gubernamentalidad- Referentes de interpretación y crítica del poder managerial. En III Congreso de la Red PILARES. Congreso llevado a cabo en Porto Alegre, Brasil.

Varela, E. (2015). Managerialismo - culturas de empresa y emergencia del "Hombre Managerial". Revista Forum Doctoral. No. 6. Pp. 1-18.

Virno, P. (2003). Gramática de la multitud: para un análisis de las formas de vida contemporáneas. Ediciones Colihue SRL. 
Grayce Kelly Bianconi: Bacharel em Direito pela Universidade Norte do Paraná (UNOPAR), Administradora em Agronegócio pela Faculdade Cristo Rei (FACCREI), Graduada em Artes pela Universidade Metropolitana de Santos (UNIMES), Pedagoga pela Universidade Castelo Branco (UCB), Pós - Graduada em Gestão Escolar, Direção e Supervisão pela Universidade Castelo Branco (UCB), Pós- Graduada em Educação do Campo pela Faculdade de Pinhais (FAPI). MBA em Gestão de Pessoas pela Faculdade Cristo Rei (FACCREI) e Pós-Graduanda em Direito Agrário e do Agronegócio pela Fundação Escola Superior do Ministério Público (FMP). PósGraduanda em Direito de Família e Sucessões pela Faculdade Damásio de Jesus

João Dallamuta: Professor assistente da Universidade Tecnológica Federal do Paraná (UTFPR). Graduação em Engenharia de Telecomunicações pela UFPR. MBA em Gestão pela FAE Business School, Mestre pela UEL. Doutorando em Engenharia Espacial pelo Instituto Nacional de Pesquisas Espaciais (INPE). Trabalha com os temas: Inteligência de Mercado, Gestão Estratégica, Gestão da Tecnologia e Inovação. 
Agronegócio 121, 124, 125, 153

Auditoria 79, 80, 81, 82, 83, 84, 85, 86, 87, 88, 89, 90, 91, 92, 93

Auditoria financeira 79,81

Auditoria independente $79,80,81,82$

C

Captura regulatória 121, 126, 127, 128, 129, 132, 134

D

Decisão 15, 24, 27, 28, 29, 30, 35, 36, 37, 38, 39, 40, 41

Direitos humanos 121, 124, 125, 126, 129, 134, 135, 136

Divisão Sexual do Trabalho 107, 113, 118, 120

E

Empreendedorismo 12, 44, 45, 46, 47, 48, 50, 51, 52, 55, 56, 57, 65, 69, 73

Escuelas 94, 95, 99, 100, 101, 102, 104

G

Gestão 1, 2, 3, 7, 8, 10, 11, 12, 13, 14, 15, 24, 25, 26, 27, 29, 30, 31, 32, 34, 35, 36, 37, 38, 41, $42,43,44,49,56,57,64,65,67,75,76,118,119,120,121,123,124,126,134,153$

Gestão da informação 27, 29, 30, 31, 32, 35, 36, 42, 43

Gestão de processos 14, 15, 24, 26

Gestão do conhecimento 27, 30, 31, 35, 36, 37, 38, 41, 43

Gestão pública 121, 123, 124, 126, 134

$\mathrm{H}$

Habermas 94, 95, 96, 98, 99, 100, 101, 102, 103, 104, 105, 106

Homossexualidade 107, 114, 116, 120

I

Inovação $1,2,3,4,5,6,7,8,9,10,11,12,13,15,24,26,28,31,42,47,65,66,67,68,69$, $70,72,73,74,75,76,77,78,153$

Inovação frugal $65,66,68,69,70,72,73,74,75,76,78$

Inteligência 5, 27, 28, 29, 34, 35, 36, 37, 38, 41, 42, 43, 153

$\mathbf{L}$

Luhmann 94, 95, 96, 97, 98, 99, 100, 101, 102, 103, 104, 105, 106, 140, 151

M

Management 2, 12, 14, 27, 28, 31, 42, 43, 45, 64, 65, 70, 71, 72, 76, 77, 78, 96, 106, 119, 122, $137,142,143,144,145,146,147,148,149$ 
Masculinidade hegemônica 107

$\mathbf{N}$

Normas de auditoria $79,84,88$

0

Organizacional $6,27,28,29,34,35,36,37,38,41,42,49,57,94,95,96,98,99,100,101$, $102,103,104,105,106,108,119,125,137,138,142,143,147,148$

Organizaciones 42, 95, 96, 97, 98, 99, 100, 101, 102, 104, 105, 137, 141, 142, 148, 149, 150

$\mathbf{P}$

Padronização de processos 14, 15, 17

Perfil empreendedor 44, 48, 49, 50, 51, 53, 54, 55, 57

Pluralidad 95, 97

Poder 32, 62, 63, 106, 125, 127, 134, 137, 138, 139, 141, 144, 145, 148, 150, 151, 152

Posmodernidad 102, 103, 104, 106, 137

Potencial empreendedor 44, 46, 48, 50, 52, 56, 57

$\mathbf{R}$

Redução de perdas 14,16

Relatório final 79, 80, 81, 82, 85, 86, 93

S

Sustentabilidade $65,66,67,68,69,70,72,73,74,75,76,77$

$\mathbf{T}$

Tecnologia 1, 2, 3, 4, 5, 6, 7, 8, 11, 12, 33, 39, 40, 43, 68, 153

Trabalho escravo 121, 122, 123, 124, 125, 126, 129, 130, 131, 132, 133, 134, 135, 136

Triple Bottom Line 65, 67 
Atena
2020 